3

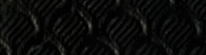

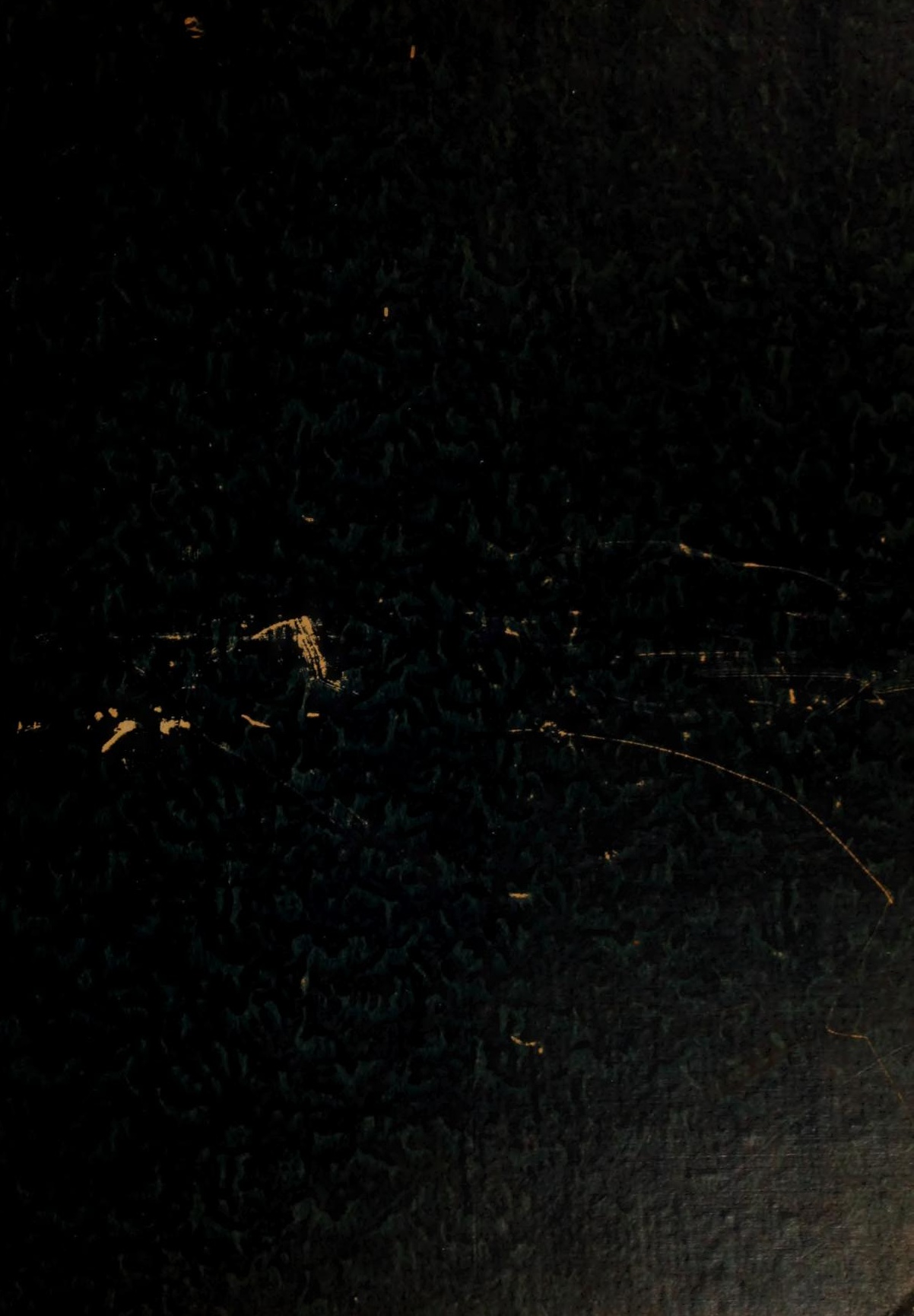




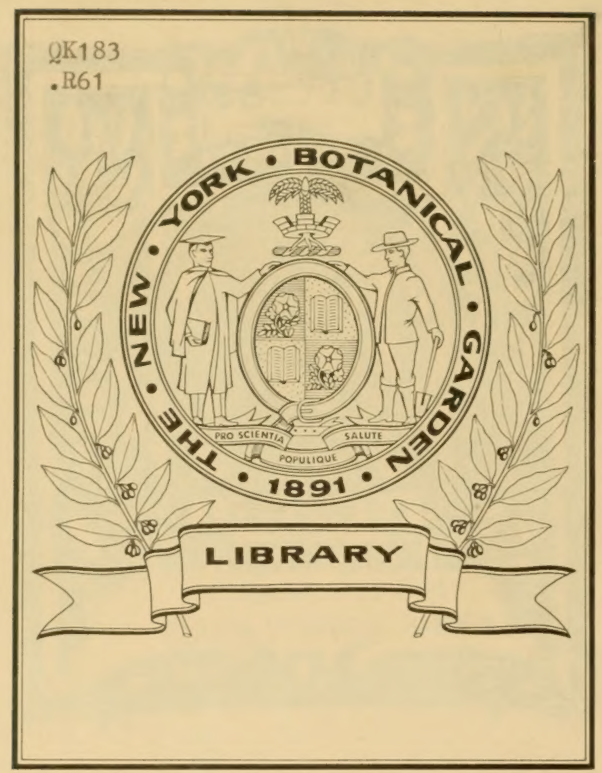




$$
\begin{aligned}
& \begin{array}{l}
\text { CONSEFVATORE } \\
\text { BOTANIQUE }
\end{array}
\end{aligned}
$$

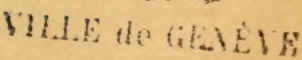





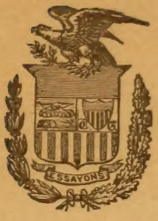

U. S. GEOGRAPHICAL SURVEYS WEST OF THE ONE HUNDREDTH MERIDIAN. 1st Lieut. GeO. M. WHeEler, Corips of Engineers, U. S. Army, in Charge.

\title{
VOL. VI.-BO'TANY.
}

\author{
CHAPTER IV.-CATALOGUE.
}

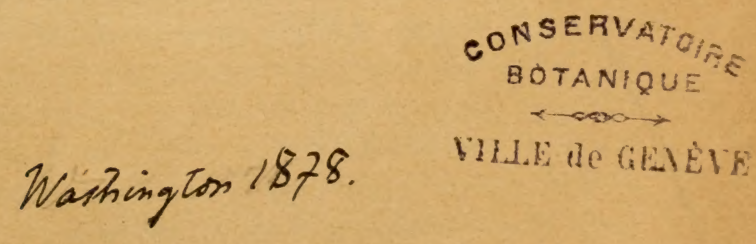





\section{United States Engineer Office, Geographical Surveys West of the}

One Hundredth Meridian, Washington, D. C., May 10, 1878.

General: I have the honor to submit herewith Chapter IV, Catalogue of Plants, being an extract from Volume VI of those authorized to be published by acts of Congress approved June 23, 1874, and February 15, 1875.

The volume comprises a number of reports upon collections of the years 1871 to 1876 , inclusive, made by Dr. J. T. Rothrock, surgeon and botanist to the Expeditions of 1873-4-5, and by eminent specialists.

The collections obtained during the several years, after their identification and classification, have been forwarded, through the Smithsonian Institution, for final lodgment in the herbarium of the Agricultural Department.

The following gentlemen have been engaged as field assistants in this branch, viz: Dr. W. J. Hoffman and Ferdinand Bischoff in 1871, Dr. H. C. Yarrow and H. W. Henshaw in 1872 , John Wolf in 1873, Dr. J. T. Rothrock in 1873-4-5, with Messrs. J. M. Rutter in 1874 and C. Shoemaker in 1875 as sub-assistants, and in 1874-5-6 Dr. Osear Loew.

Other members of the Expedition have also contributed to the large aggregate of specimens.

By dint of much pains and labor a number of species new to botanical science have been discovered, twenty-seven of which are here figured for the first time, as well as ten species rare, but not hitherto unknown. The total number of new species is fifty, and two distinct genera have been added to the known Flora of this portion of the United States. New and well-marked varieties of older species have been obtained, and among them number hitherto scantily represented in the largest herbaria. In many 
cases the wider geographical range of known forms has been developed, as, for instance, the discovery, in Arizona, of Ophioglossum vulgatum; and also a number of rare species, as of the striking leafless tree of Arizona, the Canotia, and specimens of which are thus added to the Government and other herbaria. From the Agave plants a number are described as of value for cordage and textile fabrics. The economic relations of various forageplants, native and introduced, are noted. The value of Chia (Salvia Columbaria) as a remedy and dietetic, as well as the medicinal qualities of other plants, is defined. The present and prospective relations of the forests to the settlement of the country receive mention, and tables prepared by Dr. Loew of soil analyses at important points are introduced.

Although investigations in Botany, governed in a measure by the sparsely settled condition of the regions visited, are but incidental to the systematic purpose of the Survey, which has for its main object the determination of data necessary for the construction of a detailed topographical map, yet it is believed that the material here presented, as the result of examination, by specialists, of large and complete collections, will have its value as a substantial contribution to the knowledge of the Botany of portions of the United States west of the 100th meridian and south of the 40th parallel.

Attention is invited to the authors of various parts of this report, whose names appear on the title-page, and to whom so much is due for the skill with which they have prepared their several parts, and a merited tribute to the value of their services is hereby tendered.

To Prof. Asa Gray, the veteran Botanist, to whom doubtful points have been submitted, thanks are due.

The zeal and fidelity displayed by Dr J. T. Rothrock, not only in the field, but in the preparation of his report, and in superintending the collation of other reports, are worthy of all commendation.

The excellent typographical work of the Government Printing Office in the publication of the quarto reports of the Survey is worthy of mention, while the artistic plate illustrations of this volume, furnished by Mr. Julius Bien, of New York City, are creditable alike to his artistic taste and the excellence of his establishment. The plates were drawn by the well- 
known botanical artist, Isaac Sprague, of Cambridge, Mass., and Mr. W. H. Seaman, of the Agricultural Department.

It is with pleasure that this opportunity is taken of recognizing the industry, perseverance, and skill shown by those whose combined labors have made collections the results from which are embodied in the reports herewith submitted.

Very respectfully, yours,

GEO. M. WHEELER, Lieutenant of Engineers, in Charge.

Brig. Gen. A. A. Humphreys,

Chief of Engineers, United States Army, Washington, D. C. 

University of Pennsyluania, Philadelphia, Pa., November 14, 1877.

Sir: I have the honor to transmit herewith a catalogue of the plants collected by your Expedition from 1871 to 1875 inclusive.

The plan adopted has been to describe all the species obtained by the Survey, unless they were described in Gray's Manual, or in vol. V, Botany, of King's Reports, by Mr. Sereno Watson, or either are, or are about to be, described in the Flora of California, now in preparation.

Throughout, I have received generous aid from Prof. Asa Gray and Mr. Sereno Watson. The latter gentleman contributes the entire account of the Leguminosa.

Dr. George Engelmann has elaborated for the report those orders and genera with which his name has been so long and so favorably associated, i. e., the Cactacea, Cuscuta, Gentianacee, Euphorbiacee, Asclepiadacer, Juncus, Agave, Yucca, Cupuliferce, and Conifere.

Prof. Thomas C. Porter has named and catalogued fully, with valuable notes and descriptions, the plants representing the Labiate, Borraginacea, Scrophulariacer, Polemoniacea, and Polygonacea. Mr. M. A. Bebb furnishes an account of the Willows, a genus to which he has given long and careful study.

Mr. William Boott contributes the paper on Carex. Dr. George Vasey has carefully elaborated the Graminea, and his paper forms one of the most valuable portions of the volume. The very full paper by Prof. D. C. Eaton, of Yale College, on the Filices, is believed to be a most important addition to our knowledge of the species of this order found in our Southwest. Mr. Thomas P. James and Mr. Austin have respectively named, and, when required, described, the Musci and Hepatica, and Prof. 
Edward Tuckerman has determined the Lichenes. For the remaining portions of the text I am responsible.

The collections on which this catalogue is drawn up were furnished almost entirely by the various collectors attached from time to time to the Survey under your charge, Dr. Hoffman, Dr. Loew, Prof. John Wolf, and myself obtaining the greater part. They have been obtained from Utah, Nevada, Colorado, New Mexico, Arizona, and California. There is thus brought together a large number of species, with their descriptions, that have hitherto been so scattered through our botanical literature as to be practically unavailable to a large portion of those who are interested in the botany of the regions embraced by this report.

I have the honor to be, very respectfully, your obedient servant,

J. T. ROTHROCK.

To First Lieut. Geo. M. Wheeler,

Corps of Engineers, in charge of

United States Geographical Survey. 
U. S. GEOGRAPHICAL SURVEYS WEST OF THE ONE HUNDREDTH MERIDIAN. 1st Lieut. GeO. M. WheEler, Corps of Exgineers, U. S. Army, in cint:ez.

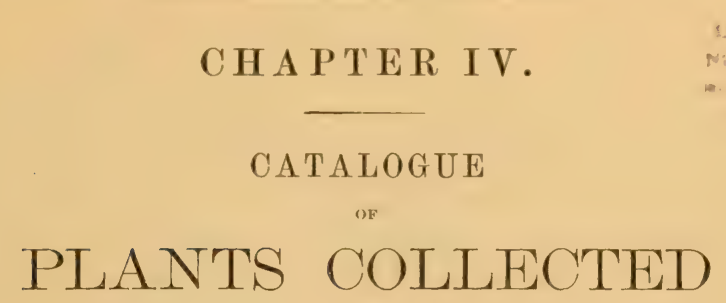

IN

NEVADA, UTAH, COLORADO, NEW MEXICO, ANI ARIZONA, WITII

DESCRIPTIONS OF THOSE NOT CONTAINED IN GRAY'S MANUAL OF THE NORTHERN U. S., AND VOL. V, GEOLOGICAL EXPLORATION OF THE FORTIETII PARALLEL.

BY

\section{J. T. ROTHROCK,}

SURFEON AND BOTANIST TO THE EXPEDITIONS OF 1873, 1874, AND 1875,

AND THE FOLLOWING BOTANISTS:

SERENO WATSON, Cambridgr, Mass. GEORGE ENGELMANN, M. D., St. Lours, Mo. Pior, thos C. PORTer, Easton, Penn. M. S. BERB, Fountaindali, ILt. IVM. BOOTT, Bostox, Mass.

GEORge VASEY, M. D., Agricultural DepartMENT, WASHINGTON, D. C.

Prof. D. C. Eaton, Yale College, New Haven, Conn.

THOS. P. James, Cambringe, Mass,

Prof. EdW Rd TUCKERMAN, Amherst, Mass. 



\section{CHAPTER IV. CA 'I A O G U E.}

\section{EXOGENS.}

\section{RANUNCULACE E.*}

Clematis Douglasir, Hook.-Clear Creek, Colorado. (92.)

Clematis ligusticifolia, Nutt.-Nevada, Utah, Arizona, and (80) from Colorado. The number 498 from Camp Bowie, Ariz., is var. Californica, Watson (Fl. Cal. I, p. 3), characterized by leaves being "silkytomentose beneath and often small".

Clematis Drummondi, T. \& G.-Diœcious, "silky villous beneath, sparingly hirsute on the upper surface" (in my specimens from Cienega, Ariz., No 567, both surfaces are smoothish), leaflets ovate, deeply and acutely 3 -lobed, sepals 4 , lanceolate-oblong, carpels quite villous, with long and plumose styles, stem slender, grooved, and altogether much more graceful than $C$. ligusticifolia.

Clematis alpina, Mill., var. Ochotensis, Gray.-Subalpine ridges among timber, at 10,500 to 11,500 feet altitude. (91.)

Thalictrum alpinum, L.-South Park, Colorado. At 10,000 feet. Typical specimens large. (94.)

Thalictrum Fendeeri, Engelm.-Nevada, Arizona, Utah, Colorado in South Park at 10,000 feet altitude. (144 and 280.)

Anemone multifida, DC.-South Park, Colorado, at 9,000 to 11,000 feet altitude. (105 and 108.)

Anemone patens, L., var. Nuttalliana, Gray.-Mountains of Colorado, at 6,000 to 10,500 feet altitude. (107.)

Anemone narcissiflora, L.-Six inches to a foot high, from a fibrous

"Signs used: The degree $\left({ }^{\circ}\right)$ indicates feet. The minute $\left({ }^{\prime}\right)$ indicates inches. The second (") indicates lines, $i$. e. r $^{2}$ of an inch. The hyphen means, to, $i, e, 6-12^{\prime}$ is 6 to 12 inches. The fignres in parentheses are numbers nuiler which the specimens were distributed. 
tufted root; petioles 1-4 inches long, leaves $3-5$ parted, each segment lanceolate-cuneate and trifid; involucre sessile, its leaflets 3-5 cleft; carpels tailless, compressed, oval, and glabrous. Entire plant more or less densely covered with gray hairs ; flowers white. Found in America most commonly from Camada north, but growing in Colorado on alpine summits, where, according to Mr. J. M. Coulter, it has been found at an elevation of 13,500 feet. (102 a.)

Anemone cylindrica, Gray.-Willow Springs, Ariz.; rare there and probably by seme accident introduced. (247.)

Mrosurus minimus, L-Colorado; altitude, 8,000 feet and upwards; specimens much dwarfed. (169.)

Ranunculus aquatilis, L., var. stagnatilis, DC-Denver. Flowers almost as large as R. Purshii, Richardson, var. trichophyllus, Chaix. Twin Lakes, Colo., at 9,500 feet altitude. (113 and 115.)

Ranunculus Flammula, L., var. Reptans, Gray.-Colorado. and 173.)

Ranunculus hydrocharoides, Gray. (Pl. Thurb. p. j06.)—Glabrous throughout, flowering branches erect, numerous stolons branching off in all directions and rooting; lower leaves heart-shaped, and entire, or nearly so; petioles 2-3' long, expanding and sheathing at the base; upper leaves lanceolate; peduncles about as long as the upper leaves, from opposite the axils of which they arise; sepals round, petals $3^{\prime \prime}$, tapering into a claw, which has a conspicuous gland below a small sinus; stamens about 25 ; carpels 15-20, forming a head $2-3^{\prime \prime}$ in diameter. Willow Springs, Ariz., growing in water at a temperature of $50^{\circ}$ Fahr. at an elevation of 7,202 feet. A most interesting species, which I believe has not hitherto been taken so far north. (217.)

Ranunculus Cymbalaria, Pursh.-In Colorado grows everywhere in low moist ground, evincing, however, a marked choice for alkaline soils, but still flourishing in the freshest of snow water; altitude, 5,000 to 10,000 f'eet.

From Saguache, in the San Luis Valley, we have a form with an erect, stout scape, bearing three or four flowers, having thicker and larger leaves, and manifesting little or no tendency to produce stolons.

At Santa Fé, N. Mex., I collected it (10) at what I presume is the 
identical location from which Fendler obtained his plant, published by Dr. Gray in Pl. Fendl. p. 4, as $R$. tridentatus, H. B. K., and this I take to be the same form as that above alluded to from San Luis Valley. In addition to the difference noted by Dr. Gray in Pl. Fendl., I find the beaks of the achenia are in my specimens more tapering than in typical $R$. Cymbalaria. Collected also in California, Eastern Arizona, and Utah. (Colorado. 101.) Ranunculus Andersoni, Gray.-Belmont, Nev. (Plate i, vol. v, King's Report.)

Ranunculus adoneus, Gray. (Enumeration of Plants, Parry, Hall, and Harbour.)- "Low, sparsely villous, becoming with age glabrous ; root fasciculately fibrous; branching from base, with one to three leaves above, either erect, simple, and one-flowered, or fleshy, decumbent, and with two or more flowers; leaves twice pedately parted, segments narrowly linear, petioles at base with dilated scarious margins ; peduncle short; corolla goldenyellow; conspicuous petals flabelliform, twice as long as the hairy, oval sepals ; scale at base adnate, small." * Usually a strictly alpine plant. My specimens, however, were obtained as low as 6,000 feet above the sea-level.

Ranunculus glaberrimus, Hook. (Flor. Bor.-Am. tab. v.)-Leaves rather lanceolate than ovate.

Ranunculus affinis, R. Br., var. cardiophyllus, Gray. $R$. cardiophyllus, Hook (Fl. Bor.-Am. tab. v.)-Colorado, at an elevation of 8,000 to 9,000 feet. (121 and 170.) Willow Springs, Ariz., at 7,202 feet altitude. Also collected by Dr. Loew in Western New Mexico.

Ranunculus sceleratus, L.-Cauline leaves, with a manifest tendency to division of the lobes; otherwise like an Eastern form. Colorado. (99, $110,111,116$.

Ranunculus Purshit, Richardson.-Among my specimens are a large number with petals trifid and the scales distinctly three-lobed. Twin Lakes, Colo, at an elevation of 9,500 feet. (117.)

Ranunculus hyperboreus, Rottb., var. natans, C. A. Meyer.-Stem weak, diffusely branched, glabrous, rooting from the nodes, creeping; leaves petioled, palmately $3-5$-cleft; $3-5^{\prime \prime}$ wide, lobes ovate, obtuse, petioles $6-12^{\prime \prime}$; peduncles naked, 6-12", often reflexed; sepals yellow, ovate, or

* When, as frequently occurs, I have been obliged to quote a specific description, it is from some imperfection in my own specimens. 
oblong, 1-2" ; carpels forming a compact, globose head, style very short or wanting. Twin Lakes, Colo. ; altitude, 9,500 feet. (100.)

Ranunculus macranthus, Scheele-Usually regarded as a mere variety of li. repens, L.; but I am satisfied from Mr. Watson's showing that it is distinct, as the greater villosity, the fewer stolons, the distinctly petiolulate leaflets, the more strictly reflexed sepals, the large flowers, and the long beaks to the carpels all indicate. Willow Springs, Ariz.; altitude, 7,202 feet.

Ranunculus recurvatus, Poir:- Style not conspicuously recurved, but in degree of hairiness, compressed achenia, relative size of sepals and petals, shape and dentition of scale, markedly corresponding with description given by T. \& G. Colorado. (162.)

Caltha leptosepala, DC.-A common and characteristic plant in our Colorado collection; 8,000 to 12,000 feet above the sea. (109.)

Trollius laxus, Salisb., var. albiflorus, Gray.-One of the most conspicuous early bloomers in alpine swamps, where, when found, it is quite abundant. Associated with the preceding plant. (102.)

Aquilegia Canadensis, L--Arizona, lava rocks south of Camp Apache. Leaves smaller than our Eastern form. (268.) Westein New Mexico, at high altitude, depauperate specimens. Coll. Loew. (164 and 167.) Utal.

Aquilegia formosa, Fisch.- "Distinguishable from the last by its elongated sepals nearly or quite equalling the spurs, and by its stouter habit, growing only on stream banks in the mountains and flowering from July to September. Nevada and Utah; ranging from the Rocky Mountains to Oregon and Sitka, but not found in California."-WATson.

Aquilegia cerulea, James.-Introduced largely into cultivation, and to my mind the finest plant of the Rocky Mountains. Western New Mexico; altitude, 6,500 feet. Loew. Colorado; open woods; common; altitude, 10,000 feet. (163.) "Near Provo City, Utah. A reduced form of this species, with bright blue flowers, was collected at Kanab in Southern Utah, by Mrs. E. P. Thompson, in 1872. It has also recently been found in the Sierras near Mount Whitney" [Cal.].-Watson.

Aquilegia chrysantha, Gray (Proc. Am. Acad. 8, p. 621). A. leptocera, Nutt., var. Alava, Gray.-Usually, though not always, taller than 
the preceding. Hard to distinguish from $A$. carulea by any mere description, as they exhibit transitions at all points. The following appear to me to be the chief differences: flower, at least in Southern specimens, always golden yellow; sepals and petals nearly the same length, 1'; inflorescence paniculate, and continuing until terminated by cold weather. Common in damp ground and ravines of the mountain streams in the White Mountains and Mount Graham of Arizona. It is certainly no exaggeration to say that I have, near the Willow Springs, seen ten acres so completely covered with this plant in full bloom, that everything else was lost sight of. Arizona, at 7,000 to 10,200 feet altitude. (196.)

Delphinium scopulorum, Gray (Pl. Wright. 2, p. 9). $-2 \frac{1}{2}^{\circ}$ high, puberulent throughout; lower leaves with petiole $4-6$ ', becoming shorter above; leaves round in outline, 3-5-parted, each division narrowly cuneate, again variously cut-lobed and toothed; raceme slender, one foot long; pedicels hairy, twice as long as the bract at base, one or two bractlets usually immediately below flower; spur over half an inch long, thickish, hairy, slightly curved, with markedly thickened extremity and one-half longer than the puberulent sepals; lower petals nearly as long as the sepals, slightly hairy within, upper one with a somewhat shorter blade, its spur nearly as long as that of the sepal; carpels 3, smoothish. Flowers are scattered loosely along the stem at intervals (when developed) of an inch. A species as variable as it is elegant. Tanks south of Camp Apache, Ariz. (263.) Altitude, 5,625 feet.

Delphinium Menziesii, DC--Nevada; Snake River, Colorado.' Dr. Vasey informs me that the plant (No. 96) which I published in the list of Colorado plants in 1874 as $D$. elatum, L, var., he has found, on comparison with the specimens in the Department of Agriculture Herbarium, to be $D$. Menziesii.

Delphinium elatum, L., var. ? occidentalis, Watson.-Plant taller $\left(5^{\circ}\right)$ and more vigorous in every way than the others; leaves three-lobed, with each lateral lobe again divided, and all the lobes variously gashed and cut-toothed. The ample foliage, the long, hooked spur, acute sepals, the distinct spur on the lower petals, so far as they go, make the limits of this species in my collection tolerably well defined. Utah. 
Aconitum Fischeri, Reich. (A. nasutum, Fisch., of my list of 1874.)$2-3^{\circ}$, smooth below, puberulent above; petioles of lower leaves $2-4^{\prime}$; leaves round in outline, 3-5-parted, with each division deeply lobed or cut-toothed; flowers in a loose raceme, pedicels $\frac{1}{2}-1^{\prime}$, pubescent, erect; petals, conical galea, and flowers from blue to purple or even white. Grows abundantly along mountain streams in Colorado. (98.) According to Mr. Watson, "A small specimen was collected in Southern Nevada with an unusually narrowed galea and long projecting beak." Also collected in Utah.

Act sa spicata, L., var. ARguta, Torr-Flowers absent; pedicels vary from less than a quarter to more than half an inch in length in the fully formed fruit. There is no perceptible thickening of the pedicel with age, and this I take to be the most reliable characteristic furnished by the fruiting specimens.

Paenia Brownir, Dougl.-Nevada.

\section{BERBERIDEA}

Berberis Fendleri, Gray (Pl. Fendler. p. 5).-Shrub 3-6 ${ }^{\circ}$; branches and branchlets smooth and shining, as if vamished; spines 3-5-parted; leaves oblong-lanceolate, acutish, entire, or irregularly spinulose-serrate, entirely glabrous; racemes pendulous, $1-2^{\prime}$, and densely flowered, somewhat longer than the leaves, which, however, vary much in size in adult condition; calyx with conspicuous red bracts, which are a little shorter than the sepals. Flowers yellow and as large as those of $B$. vulgaris. Unripe fruit with 2-3 seeds; blooms in May and June. I probably collected my specimens from the exact spot at which Mr. Fendler obtained his. The shrub appears to be by no means common. Santa Fé, N. Mex. (54.)

Berberis repens, Lindl.- "A low, somewhat procumbent shrub, less than $1^{\circ}$; leaflets $3-7$, ovate, acute, not acuminate, $1-2 \frac{1}{2}^{\prime}$, not shiny above; racemes few, terminating the stems, $1-1 \frac{1^{\prime}}{}{ }^{\prime}-$ Bot Reg.t.1176. B. Aquifolium, Pursh, mainly, and of numerous authors."-(Fl. Cal. 1, p. 14.) I have not seen the species.

Berberis Aquifolium, Pursh.-Common in mountain parts of Central Colorado. (57.)

Berberis Fremontir, Tort-Leaves pinnate, with 3-4 pairs of leaflets, 
the lowest pair of which is situated uniformly close to the insertion of the petiole; leaflets ovate, repand, spiny-dentate (In my specimens from Southern Utah, the leaflets are hardly half an inch long. Torrey, however, in Bot. Mex. Bound. p. 31, states that the leaflets are from 1-21'.) Racemes erect, 5-7-flowered, longer than the leaves; pedicels over half an inch long; flowers golden yellow, half an inch in diameter; filaments inappendiculate; berries large as currants. Its nearest affinity is with $B$ trifoliata, but it has more leaflets, longer racemes, and blue instead of red fruit. Arizona.

\section{PAPAVERACE E.}

Argemone Mexicana, L., var. hispida, Torr. (A. hispida, Gray, Pl. Fendl. p. 5.) —Santa Fé, N. Mex., where it quite covers the vacant lots on the outskirts of the town. Collected also in Utah.

Corydalis aurea, Willd., var. occidentalis, Engelm.-Like our Eastern form of $C$. aurea, except that it has a longer spur, erect pods, and lenticular seeds with acute margins. Apparently this is the more common form from Colorado south along the main mountain axis. Sierra Blanca, Arizona, at 9,000 feet altitude (813); Nevada, Prof. Loew ; Santa Fé, N. Mex. (55); and Colorado.

\section{CRUCIFERA.}

Cheiranthus Menziesii, Benth. \& Hook.-Carlin, Nev.

Nasturtium sinuatum, Nutt.-(618.) From San Luis Valley, on the alkaline flats; leaves absolutely coriaceous, though beautifully and regularly pinnatifid; (625) is from Apex, Colorado; like the other, though with much thinner leaves; (123) is from New Mexico, as is also (99), but which has quite acute tips to the lobes of the leaves: has also been collected by the Expedition in Nevada.

Nasturtium obtusum, Nutt.-Twin Lakes, Colorado. (617.)

Nasturtium Palustre, DC.-Twin Lakes, Colorado. (627.)

Nasturtium palustre, DC., var. hispidum, Gray.-San Luis Valley, Colorado. (626.)

Arabis PERfoliata, Lam. (Turritis glabra, L.)-In the enumeration of 
1874, I had regarded this as an unusual form of $A$. hirsuta. Twin Lakes, Colorado $\quad(650)$

Arabis Drummondi, Gray.-South Park, Colorado. (655.)

Arabis Holbellir, Hornem.-Common and variable. Colorado and Nevada.

Cardamine cordifolia, Gray.-1-2 ${ }^{\circ}$. Generally erect, from a fibrous root, which not unfrequently is in the water; leaves all petioled, cordate in outline, irregularly repand-dentate or sinuate, sparingly ciliate; siliques erect, twice as long as the pedicels. Common in Colorado at 10,000 feet altitude, in swamps and mountain streams. (608, 609,610.)

Vesicaria Ludoviciana, DC.-Hoary throughout, with a stellate pubescence, erect, 6-10' high, usually branching; root-leaves spatulate; stem-leares linear to linear-lanceolate, all obtuse; flowers yellow; petals obovate, one-half longer than the sepals; pods oval, somewhat inflated, rather shorter than the style; pedicels 6-9" long. Colorado. (641.)

Vesicaria montana, Gray.-Colorado. (647.) By some oversight, I transposed the labels of these two species in distribution of the collection of 1873 .

Physaria didymocarpa, Gray.-Alpine and sub-alpine in Colorado. (642, 648.) The Expedition has it also from Nevada and Utah.

Draba aLPina, L-A very attractive little perennial found in Colorado at 10,000 to 13,500 feet altitude; its favorite habitat being above timber line. (646)

Draba aurea, Vahl.-Pubescent, erect; stem usually quite leafy; leaves lanceolate, acute, entire or sub-entire; siliques lanceolate, acute, nearly twice as long as the pedicels, hairy and more or less twisted; style $\frac{1}{2}$ "long; petals yellow. A very variable species, of extended range. The Expedition has it from Colorado, New Mexico (Loew 633 and 634); and from the higher mountains of Arizona, the var. stylosa.of Gray (1111).

Draba streptocarpa, Gray.-Alpine in Colorado, along with aurea. My specimens furnish a singular example of transposition of characters usually reliable in distinguishing between these species; $i$. e., aurea and streptocarpa. The specimens which have the fruit most characteristic of streptocarpa are in other respects most like (generally including length of 
style also) aurea. I must, however, say that the fruit is in no instance so much twisted as in the original specimens on which streptocarpa was founded. That differences sufficient to constitute distinct species exist between the extreme forms, no one will probably deny. It is equally certain that they shade into each other until at times all tests are doubtful and justify a place under either name. In this instance, I have named as streptocarpa all specimens having leaves "beset and especially ciliate, with long and rigid, shaggy, spreading, simple or simply forked hairs, far more bristly than in D. aurea, and with no fine stellular pubescence intermixed." I rely more on this character in deciding between interloping specimens than on any other.

Draba incana, L., var. confusa, Hook.-I have from Colorado (number mislaid) a plant similar to herbarium specimens that are authentically named, and that bear the above name.

Draba montana, Watson.- "Annual, hoary-villous, with simple or branching rigid hairs, rather stout, erect, simple or sparingly branched from near the base, becoming a span high or less; leaves rosulate and rather crowded at and above the base of the stem, oblanceolate and oblonglanceolate, acutish, sparingly toothed, half an inch long or less; flowers small, the yellow or yellowish petals $1-1 \frac{1}{2}$ long, exceeding the sepals; pods linear-oblong, obtusish, roughly puberulent, about $4^{\prime \prime}$ long, nearly erect upon the spreading pedicels, which are $2^{\prime \prime}$ or $3^{\prime \prime}$ long; style none.Collected in Colorado by Hall and Harbour, without number; in South Park by Wolf (637), and near Empire by Rev. E. L. Greene. It is distinguished from $D$. nemorosa by its stouter and less branching habit and its more erect pods on stouter pedicels, and from $D$. stenoloba by its stouter habit, greater pubescence, and somewhat broader and obtuser pods."-WATson, MS.

Draba nemorosa, L., var. Lutea, Gray.-Georgetown, Colo. Stems less leafy and pedicels shorter. (628.)

Numbers 635 and 636 of the Colorado collection I had named $D$. nemorosa, L., var. crassifolia, Watson, from the resemblance to Draba crassifolia, Graham, in Hall and Harbour's 1862 collection. Brewer and Watson (Fl. Cal. 1, p. 28) speak of this, however, as having a naked and scapelike stem, whereas my specimens are leafy. I therefore leave them simply under $D$. nemorosa, L. 
Sisymbrium carescens, Nutt-Colorado and Nevada. From Ash Creek, Arizona, I have specimens (306) that are an enigma to me; the very sharp cut to the leaves, the great glandular-hairiness, the linear pods, and filiform pedicels almost tempt me to call it a new species It does not appear to be either incisum of Engelman or auriculatum or diffusum of Gray.

Sisymbrium incisum, Engelm. (Pl. Fend. p. 8). (S. Californicum, Watson, in King's Report)-Nevada and Utah.

Sisymbrium virgatum, Nutt.-"6-12' high; stems simple or branclied from the base (or sometimes branched above), slender, covered below with an ashy, simple, or forked pubescence; leaves tomentose pubescent ; those of the root petioled, lanceolate-oblong, and sinuate-dentate; stem leaves sessile, lanceolate, auriculate, and clasping at base, entire, denticulate, or slightly wavy-margined, 6-8 $8^{\prime \prime}$ long ; flowers pale purple, $2^{\prime \prime}$ in diameter ; stigma almost sessile; pods 1-1 $\frac{1}{2}$ ' long, and $3-4$ times exceeding the slender pedicels; seeds 4-angled, 'in a double series.'” (605, 606, 652.) South Park and Twin Lakes, Colorado.

Smelowskia calycina, Meyer--Alpine regions of Colorado. (601.)

Erysimum cheiranthoines, L-Twin Lakes, Colorado, 9,000 feet altitude. (651.)

Erysimum asperum, DC.-Nevada and Utah.

Erysimum asperum, DC., var. Arkansanum, Nutt-Central Colorado. $(593,596,599,640$.

Erysimum asperum, DC., var. pumllum, Watson.-Biue River. (594.)

Erysimum Wheeleri, sp. nov. $-3-5^{\circ}$ high, erect, unbranched, sparsely covered with closely appressed hairs, which are fixed by the middle (very rarely forked), never 4-parted; root-leaves, including petiole, into which they gradually taper, 2-4' long, narrowly lance-linear, entire or sub-entire; stem-leaves narrowly lanceolate, sessile, 1-2 $\frac{1}{2}{ }^{\prime}$ long, entire: pedicels (in fruit) $\frac{1}{4}-\frac{x^{\prime}}{2}$ long; mature pods erect, 1-2' long (in younger pods there are distinct ribs between the angles), canescent; stigma twolobed, style evident; seeds attached to each side of cell; cotyledons obliquely incumbent; petals varying from yellow to scarlet, twice as long as sepals, claw $\frac{1^{\prime}}{3}$ long, nearly filiform, lamina obovate, little over $\frac{1}{4}$ long. 
This is a strikingly showy plant; stem rises gracefully to a height of 5 feet often, and is crowned with a cluster of scarlet mottled flowers.

The lax, scattering arrangement of the leaves is in striking contrast to the usually more crowded arrangement in E. asperum. Judging from the description in Flora of North Am. T. \& G. p. 95, I should think its nearest affinity would be E. elatum, Nutt. MSS. Still it appears distinct from this, all the more probably so, as the only points at which it was taken were Camp Grant, Ariz., and Mount Graham, near by, but 5,000 feet higher, where it had developed some local peculiarities without bringing it any nearer known species. The stem of the mountain plant was more light, airy, leaves smaller and more numerous, and pods longer, but with essentially the habit of the same species at the foot of the mountain.

I am loth to name a new Erysimum, for reasons which are apparent to all who have studied the genus. Still, this seems too well marked a species to pass it by.

Thelypodium integrifolium, Endl.--South Park, Colorado Nevada and Utah.

Thelypodium linearifolium, Gray.-Very smooth, $3^{\circ}$; leaves few, linear or linear-lanceolate, sessile, 2-3' long, 2-3" wide, slightly glaucous; petals purplish, with claws twice as long as the sepals; style very short; seeds immarginate, oblong.. (154.) Pescao, N. Mex.

Thelypodium sagittatum, Endl--Carlin, Nev.

Thelypodium longrfolium, Watson. (Streptanthus micranthus, Gray, Pl. Fendl. p. 6.) -Stem slender, $2^{\circ}$, roughish below, glabrous above; flowers 1-2" long; leaves hirsute, somewhat toothed, or lower leaves distinctly dentate; pods erect or pendulous, terete. Sanoita Valley, Arizona. (610.) Altitude, 6,500 feet.

Thelypodium Wrightir, Gray (Pl. Fendl. p. 7).-Biennial?, 2-30 high; smoothish leaves, narrowly lanceolate; lower ones pinnatifid, deeply dentate or even sub-entire; upper ones sub-entire or entire. All tapering into petioles, upper ones $2^{\prime \prime}$ wide, $1-2 \frac{x^{\prime}}{2}$ long; pedicels in fruit $\frac{1}{4}-\frac{3^{\prime}}{4}$ long; spreading. Pods erect, or nearly so, $1 \frac{1}{2}-21^{\prime}$ long, filiform. Petals white, clawed, a little longer than the sepals. The aspect of the plant is peculiar from its densely spicate flowers, leaving a mass of long; thread-like pods at 5 BO' 
the summit of the stem. There is great variation in the degree to which the leaves are cut or toothed and in the hairiness of the entire plant. Camp Grant, Ariz., at 4,753 feet altitude. (363.)

Camelina satrva, Crantz.-Introduced in Colorado.

"Tropidocarpum* Gracile, Hook.-Stems weak, 2 feet high or less; leaves pinnatifid or rarely 2-pinnatifid, with narrow, or linear segments; flowers in the axils of the upper bract-like leaves; petals $1 \frac{1}{2}-3^{\prime \prime}$ long, nearly twice longer than the obtuse sepals; pods 6-20" long, more than a line broad, pointed at both ends, ascending or slender spreading pedicels 10-20" long. San Francisco Mountains, Arizona." I have not a specimen accessible, and therefore have been obliged to quote generic and specific description from Fl. Cal. 1, p. 44.

Caulanthus crassicaulis, Watson.-Frequently called Wild Cabbage, and used as a substitute for the better article. Nevada.

Lepidium intermedium, Gray-The usual apetalous Western form. Boulder, Colo., Loew and Wolf. (597.)

Lepidium alyssoides, Gray. (Pl. Fendl. p. 10.)-Keasby, collector. Peoria Creek, New Mexico.

Lepidium montanum, Nutt.-Old Camp Goodwin, Ariz. (341.) 3,000 feet altitude. San Luis Valley, Colorado. (624.)

Lepidium Fremonti, Watson?-Probably this species. Specimen too young. Collected by Dr. Loew in Nevada. (King's Report, vol. v, plate iv.) Lepidium nanum, Watson. (King's Report, vol. v, plate iv.)-Halleck Station, Nev.

Thlaspi alpestre, L. (?)-I have no sufficient means of comparing this with the European plant, but accept Mr. Watson's determination. Exceedingly variable. Common in alpine and sub-alpine regions of Central Colorado. (607.)

Biscutellat (DithyraA) Wisluzeni, Engelm.-A foot or more high,

* "Tropidocarpum, Hook.-Pod linear, flattened laterally, often one celled by the disnppearance of the narrow partition; valves carinate, 1-nerved. Seeds in two ruws, miuute, flattened, not winged; cotyledons incumbent. Style short.-A low, slender, birsute, brauching annual, with pisnately divided leaves, and yellow solitary axillary flowers."

† Biscutella, L.-Sepals nearly equal. Silique dehiscent, very flat, divided into lateral ovate halves, each of which is surrounded by a cord-like margin. Each cell contains a single immarginate seed. Herbs, nanally erect, branching and hispid; leaves more or lęs pinnatifid; flowers bractless, yellow. 
covered throughout with a fine, but dense, stellate pubescence; leaves linearlanceolate to broadly lanceolate, entire, slightly undulate or deeply pinnatifid; pedicels $3-8^{\prime \prime}$ long and in fruit most frequently spreading or deflexed; each half of the pod roundish, from 1-3" in diameter; style $\underline{y}^{\prime \prime}$ long; sepals hairy outside; nearly as long as the petals. New Mexico, from Zuñi River, near, I think, the location of the first discovery of the plant. Also obtained in Arizona.

\section{CAPPARIDEA.}

Cleome aurea, Nutt.-Boulder, Colo., 1873. Loew.

Cleome nutea, Hook.-Much like C. aurea, except that the stamens are unequal and unlike; of the six, two are longer, with small, curved anthers, and four are shorter, with mucronate anthers. The figure (tab. xxv in Hook. Fl. Br. Am.) shows by mistake two short and four long anthers. Nevada.

Cleome Sonoræ, Gray.-Annual, glabrous, erect; leaves trifoliate, with short petioles; leaflets entire, linear; pod turgid, somewhat longer than the stipe, which is about $\frac{1}{3}-\frac{1}{2}$ as long as the pedicel; flowers purplish. Anthers 6, linear. San Luis Valley, Colorado. (761.)

Cleome integrifolia, T. \& G.-Utah.

Cleomella Parviflora, Gray.-Nevada.

Cleomella longrpes, Torr.-Loew. (180.) No locality assigned; probably from Arizona.

Cleomella obtusifolia, Torr. \& Frem.- "Branching from the base and diffuse; leaflets cuneate-obovate, obtuse; style filiform. Annual, stem smooth, the branches spreading, about a span long, hairy in the axils. Leaves or petioles an inch or more in length ; the lamina of the leaflets 4$6^{\prime \prime}$ long, apiculate with a deciduous bristle, nearly smooth above, strigose underneath. Pedicels solitary and axillary, in the upper part of the branches, longer than the petioles. Calyx much shorter than the corolla, the sepals lacerately $3-5$-toothed. Petals yellow, oblong lanceolate, obtuse, about $3^{\prime \prime}$ in length. Stamens 6 , unequal, a little exserted; anthers linearoblong, recurved when old. Torus hemispherical. Ovary on a long slender 
stipe, obovate; style longer than the ovary."-(Torr. Fremont's Report, p. 311.) Nevada.

Polanisia uniglandulosa, DC.-Loew. New Mexico.

Polanisia graveolens, Raf-Upper Arkansas Valley, Colorado (760); also New Mexico.

\section{VIOLACE $A$.}

Viola Canadensis, L.-Westem New Mexico, Valle Grande, Loew, 1873, and Apex, Colorado. (77 and 78.)

Viola canina, L.-Colorado and Nevada. (75.)

Viola cucullata, Ait-Western New Mexico, at 6,500 feet altitude.

Viola Nuttalli, Pursh.-Colorado, near Denver. (76.) Nevada.

\section{BIXINE E.}

Amoreuxia* Scheideana, Planch. (Pl. Wright. 1, tab. 3, and 2, tab. 12).-Glabrous or nearly so, $1^{\circ}$ high, leaves on long petioles, orbicular in outline, 7-9-parted, with the lobes obovate, cuneate at base and sharply serrate toward the top; capsule $1^{\prime}$ long and nearly as broad, moderately inflated; seeds curved and minutely roughened with short, scattering hairs; flowers deep orange, with brownish markings in the centre. Sanoita Valley, Arizona. Altitude, 5,500 feet. (647 and 640)

\section{POLYGALE E.}

Polygata alba, Nutt.-Perennial, with several slender virgate stems ascending from the same root, smoothish, $1^{\circ}$ high; leaves linear to oblanceolate, sessile or barely petioled, margins slightly revolute; stem leafy half way to the summit; flowers deciduous, leaving the rachis roughened after their fall, white; wings of the calyx rounded, about as long as the corolla; seed with caruncle extended into two ear-like lobes nearly as long as the seed. Willow Spring, Ariz. Altitude, 7,195 feet. (207.)

- Amoreuxia, Moc. et Seas. in DC. Prod. ii, p. 638.-Flowers hermaphrodite. Sepals 5, imbrieated, deciduous. Petals 5, large, contorted-imbricated. Stamens many, inserted upon the glandlese receptacle; anthers linear, bivalved, with ohort confluent lines of dehiscence under the apex. Ovary perfectly 3-celled; placentas united in the centre, ovules many; style simple, stigma minutely denticulate; endocarp membranous, separating into 3 valves alternating with those of the epicarp. Seeds obovoid, straight or incurved, smooth, testa bony, surrounded by a loose exterior membrane; cotyledons broad, eurved, or with an incurved hook.-Bелтнам \& Нооквr. 
Polygala puberula, Gray (Pl. Wright. 1, p. 40).-Perennial, with several erect or sub-erect stems from the same root, covered with a very soft, short, ash-colored pubescence; leaves with very short petioles, ovate, lance-ovate, or lanceolate, obtuse, but slightly mucronate, leafy to the raceme, which is lax and somewhat elongated; flowers and fruit pendulous; keel naked; wings ovate or obovate, and very slightly ciliolate; pods oval, ciliate, and covered with a very soft down when young; when older, hairiness is limited to the thickened margin. Floral envelopes are deciduous, leaving the pod naked. An interesting, though variable species. (312.) Ash Creek, Arizona. (504 and 459.) Camp Bowie, Ariz.

Monnina * Wrightir, Gray (Pl. Wright 2, p. 31).-Annual, erect, smooth; leaves narrowly lanceolate, acutish, entire, with a petiole $\frac{1}{2}{ }^{\prime \prime}$ long; raceme terminal, or secondary racemes coming out of the axils; fruit and flowers on pedicels $\frac{1}{2}-1^{\prime \prime}$ long, deflexed; flowers 1-2" long, greenish, with distinct purple blotching; fruit $2^{\prime \prime}$ in diameter, winged, on one side much larger than on the other. (622.) Sanoita Valley, Arizona.

\section{Krameria Parvifolia, Benth.-Cienega, Ariz. (572.) Nevada.}

\section{FRANKENIACE E.}

Frankenia $\dagger$ grandifolia, Cham. et Schlecht.-Stem usually prostrate, $6-12^{\prime}$ long, woody or hard at base; leaves $6^{\prime \prime}$ long, cuneiform, mucronate ; margins slightly revolute, thickish, under the lens hairy and ciliate at the base, connected at their insertion by a hairy, stipular membrane. Southern

* Monnina, Ruiz. et Pav.-Sepals unequal, 2 interior large, petaloid and wing-like. Petals 3 keel concave-galeate, entire or broadly 3 -lobed (from the two exterior petals being united with the keel ?), free; 2 interior shorter, sub-connivent, various]y shaped, inserted npon the stamineal tube. Stamens 8 , united in a sheath; anthers 1-2-celled, opening introrsely by an oblique apicular foramen. Ovary 1-2celled; style incurved; stigma two-lobed at the apex. Fruit indehiscent, 1-2-seeded, either drupaceous, or dry and wingless, or margined with a membranous wing. Seeds estrophiolate, glabrous; albumen almost none; cotyledons thickish. Herbs, shrubs, or small trees. Leaves alternate or scattered. Raceme spike-like, terminal, lateral, or occasionally axillary.-BENTH. \& НоОк.

† Frankenta, Linn.-Calyx tubular or prismatic, furrowed; the 4 or 5 lobes valvate and induplicate in the bad. Petals 4 or 5 , hypogynous; the blade tapering into a claw, which bears an appendage (crown) on its inner face. Stamens 4-7 or rarely more, hypogynous, Ovary 1-celled, with 2-4, few- to several-ovuled parietal placentæ; style 2-4-cleft into filiform divisions; stigmas nnilateral. Capsule included in the persistent calyx, 2-4-valved; the few or several seeds attached by filiform stalks to margin of the valves. Leaves small, mostly crowded and also fascicled in the axils, sessile or pearly 80 , the pair often united by a membranous, somewhat sheathing baso; flowers small, perfect, solitary and sessile in the forks of the stem, or by the reduction of the upper leaves to bracts becoming cymose-clustered on the branches; corolla pink or purplish.-Fl. Cal. i, p. 60. 
Nevada, of which form Mr. Watson remarks, "Nearly glabrous, with some stiff hairs upon the stipules and traces of pubescence upon the sten and capsules. The leaves are intermediate between the ordinary form of California, with mostly obovate leaves, and those of the recently described species (F. Jamesii, Torr.; Gray in Proc. Amer. Acad. 8, 622). Colorado and Texas."

\section{CARYOPHYLLEE.}

Saponaria Vaccaria, Host.-Introduced about the Mormon settlements in Utah.

Silene ACaulis, L.-Utah, Colorado, among the mountains at 11,500 feet altitude and upward. (362.)

Silene Menziesir, Hook.-Twin Lakes, Colorado. (355.)

Silene GregGir, Gray (Pl. Wright. 2, p. 17). (Melandrium Greggii, Rohr.)-More or less viscidly pubescent; two or three erect stems from the same perennial root; lower leaves lance-ovate or obovate, shorter than the upper, which are lanceolate to ovate, sessile or tapering into very short petioles, $1 \frac{1}{2}-2^{\prime}$ long; calyx-lobes obtuse, or acute, sometimes with scarious margins; lamina of petals crimson, divided into 4 lobes, of which the lateral are the shorter, corona 2-parted, truncate, with the lobes slightly erosedentate. Stamens exserted. Mount Graham, 7,000 to 9,500 feet altitude. $(420,734$.) Also collected by Dr. Loew on the mountains of Arizona. This species Mr. Watson considers a variety of \&. laciniata, probably correctly.

Silene Scouleri, Hook.-Stem erect, smooth below and slightly glandular-pubescent above; leaves narrowly lanceolate, tapering very gradually to the base, lowest $6^{\prime}$ long, upper ones shorter; racemes subcompound, i.e., two or three flowers coming off at the same point of the stem. Calyx about as long as the pedicel, lobes acute, with scarious, ciliate margins; petals white or flesh-colored, claws with acute auricles, filaments woolly, ciliate; capsule three times longer than the stipe. Mount Graham, Arizona, at 9,000 feet altitude. (739.)

Lychis APETALA, L-Colorado.

Iiychnis Drummondi, Watson.-South Park, Colorado.

Cerastium vulgatum, L-Colorado. (352.) 
Cerastium nutans, Raf--Sierra Blanca, Arizona, at 9,000 feet altitude (803), and Mount Graham (403).

Cerastium arvense, L.-South Park and Blue River, Colorado. $350,351,353$.

Stellaria Jamesir, Torr:-Colorado (339), Nevada, and Utah.

Stellaria longipes, Goldie - Colorado. (338, 340.) The plant (340) from Colorado, which I published and distributed as S. longifolia, is without doubt S. longipes.

Stellaria crassifolia, Ehrhart.-Nevada.

Arenaria saxosa, Gray (Pl. Wright. 2, p. 18).-Perennial, 5-12' high, slightly hispid-pubescent; leaves sessile (lower ones sub-connate at base), lanceolate acute, $6^{\prime \prime}$ long, $1-2^{\prime \prime}$ wide; raceme many-flowered, somewhat wmose, pedicels $\frac{1}{2}-\frac{3 \prime}{4}$ long; sepals very acute, somewhat scariousmargined, with a distinct, almost keel-like midrib, which is decidedly hispid; the obovate white petals as long as, or a little longer than, the sepals. (412.) Mount Graham, Arizona, at 9,000 feet altitude.

My specimens appear decidedly more luxuriant than those on which the species was founded. The distinctive features are so well marked, however, that I can hardly consider it as anything else.

Arenaria capillaris, Poir-Utah.

Arenaria Fendleri, Gray (Pl. Fendl. p. 13).-South Park, Colorado (349), and near Cosino Caves, Arizona, in pine woods. Loew, collector.

Arenaria Fendleri, Gray, var. subcongesta, Watson.-Twin Lakes, Colorado, 11,00J feet altitude (868); Utah.

Arenaria verna, L.-Mosquito Pass, Colorado. (345.)

Var. Hirta, Fenzl.-More densely cæspitose than the typical 'A. verna; leaves broader, rougher, and obtuse; flowering stems shorter. South Park, Colorado. (346.)

Arenaria (Alsine) biflora, Wahl--Under this I include all the numbers 364, 343, 344, representing respectively the names $A$. arctica, Stev., var. obtusa, A alpina, L., A Rossii, R. Br, of the catalogues of the Colorado collection It was by a clear inadvertency that the name $A$ alpina, L., was used at all, as it does not, so far as I can find, appear any- 
where as a species of Limmans's. I also include the same name in Porter's and Coulter's Flora of Colorado.

Cæspitose, more or less woody at the base, forming either a compact mass, or sometimes with the stems more lax and lengthened; leaves sometimes obscurely three-nerved, narrowly linear, more or less roughened; peduncles pubescent; petals longer than the obtuse sepals.

Arenaria lateriflora, L.-Twin Lakes, Colorado.

Sagina Linnæi, Presl.-Colorado. (341, 342.)

Drymaria* effusa, Gray (Pl. Wright. 2, p. 19).-Annual, smooth; root-leaves ovate, short-petioled, $2^{\prime \prime}$ in diameter; lower internode $2^{\prime}$ long; stem-leaves linear-setaceous, 4-8" long; dichotomously branched above; pedicels very slightly glandular pubescent, twice as long as the flower; sepals obtuse, with scarious margins; petals quite narrow, deeply two-lobed, and a little longer than the sepals. The whole plant is hardly three inches high. (619.) Sanoita Valley, Arizona, at 6,500 feet altitude. Found, so far as $I$ have seen, only among the oak trees and on a gravelly soil.

\section{PORTULACACE E.}

Portulaca oleracea, L. ? ?-The specimens from Colorado (989) are all too old to determine with certainty.

Portulaca lanceolata, Engelm.?-Arizona. Poor specimens. Chiricahua, Southern Arizona, growing on dry sandstone rocks. (521.)

Talinum aurantiacum, Engelm.-Herbaceous, with a woody base, $1-2^{\circ}$ high, erect or sometimes branching from the base, glabrous or with a few spreading hairs; leaves lanceolate, thickish, sessile, 1-2' long; peduncles with two small bracts, $4-5^{\prime \prime}$ long, articulated above the base; flowers orange-colored, single in the axils, somewhat reflexed in fruit; sepals 4-5" long; petals somewhat longer; mature seeds black, elegantly marked with strong circular lines, and with others less strong, but transverse to them. (346.) Cottonwood, Ariz., in rocky places.

" Drzmaris, Willd,-Sepals 5, herbacecus or with scarions margins. Petals 5, 2-6-cleft. Stameus 5, or fewer by abortion, somewhat perigynous. Ovary 1-celled, with many ovules; style 3-cleft. Capsule 3-valved. Seeds roundish kiduey-shaped, or laterally compressed, hilum lateral; embryo peripheral. Diffuse or rarely erect herbs, branching dichotomously. Leaves flat, broad or narrow. Stipules small, often fugacious. Flowers pedicellate, solitary in the forks, or often in terminal cymes or axillary and scattering.-BENTHAM \& НОоКЕR. 
Talinum aurantiacum, Engelm., var. angustissimum, Gray.-Similar to the above, except that the leaves are linear, the articulation of the peduncle often nearer the axil, sepals approaching the orange color of the corolla, and the plant usually lower, averaging $8^{\prime}$ in height. . (538.) Rocky ledges at Chiricahua Ageney, Arizona.

Talingm Patens, Willd.?-1-2 ${ }^{\circ}$ high, glaucous; leaves broadly lanceolate, thin, entire; flowers purple, in bud twice longer than the obtuse sepals; inflorescence loose, panicled along the slender branches; seeds not mature enough to certainly identify the specimen. (522.) Chiricahua Agency, Arizona, on rocky ledges, along with T. aurantiacum var. angustissimum.

Calandrinia* pygmea, Gray (Proc. Am. Acad, viii, p. 623). (Talinum pygmacum, Gray.)-Colorado.

Claytonia artica, Adams, var. megarhiza, Gray.-High mountains of Colorado; strictly alpine. The large root penetrates a foot or more among the rocks. (74.)

Claytonia Chamissonis, Esch. \& Ledeb.-Seeds evenly and beautifully roughened with minute scale-like markings. I find no allusion under description of this species to the markings of the seed, nor have I any ripe seed in other authentically determined specimens of the species, but in all the other characteristics my plant is so like the broader-leaved form, No. 84, of Hall and Harbour, that I cannot doubt the specific identity of the two. (219.) Willow Spring, Ariz.; altitude, 7,195 feet. Found growing luxuriantly in spring water the temperature of which was $52^{\circ}$ Fahrenheit.

Claytonia Caroliniana, Michx., var sessilifolia, Torr. . (C. lanceolata, Pursh.)-Nevada.

Lewisia Rediviva, Pursh.-Nevada.

\section{ELATINEA.}

Elatine Americana, Arn.-Twin Lakes, San Luis Valley, and Rio Grande at Loma, Colo. (775, 776.)

" Calandrinia, H. B. K.-Differs from Talinum, Adans., chiefly in baving persistent sepals and estrophiolate seeds. 


\section{TAMARISCINE $\mathrm{E}$}

Fouquiera * splendens, Engelm.-Shrub 5-150 high, spiny, with clusters of leaflets in the axils of the spines (the larger primary leaves being seldom seen); flowers in a strict or a thyrsoid panicle, bright scarlet, $1^{\prime}$ long. A most remarkable looking plant (standing usually out on an open sun-exposed slope), with its strict, striated, almost leafless stem crowned by a mass of beautiful scarlet flowers.

HYPERICINEA.

Hypericum Scouleri, Hook-Utah, Arizona. (210, 384.)

MALVACE E.

Sidalcea Candida, Gray.-Collected by Mr. Hance, but neither number nor locality given. Probably from New Mexico or Arizona.

Sidalcea malvæflora, Gray.-A somewhat variable and widely diffused species. The Expedition has it from Colorado to Southern Arizona and New Mexico and west to Southern California.

Malvastrum coccineum, Gray.-Colorado, Arizona, New Mexico, Utah. The var. dissectum, Gray, we have also from Utah and New Mexico. So far as my specimens go, the variety seems to evince a marked liking for the more dry and sandy regions

Malvastrum Munroanum, Gray.-Not unlikely that this and Spharalcea Emoryi, Torr., are the same, as according to Mr. Watson's showing the two correspond in all respects, save that the latter usually has two seeds to the carpel. It sometimes has but one, and then the distinction vanishes. Mineral Hill, Nev.

Anoda† hastata, Cav., var. depauperata, Gray (Pl. Wright. 2, p. 23).-

- Foveviera, H. B. K.-Sepals 5, free. Petals united into a tube ; the lobes of the limb imbricated, spreading. Stamens 10-15, bypogsnous, exserted; filaments thickened at base. Ovary imperfectly 3-celled; placentro abont 6.ovuled; styles 3, long, somewhat united. Seeds 3 to 6, ollong, flattenei, surrounded by a dense fringe of long white hairs or by a membranous wing.- Sbrubs or small trees, with soft fragile wood, smooth; the branches alternately spinose-tnbercled, and with single or fascicled thick entire leaves in the axils; flowers brilliant erimson, in terminal spikes or panicles.-Flora Cal. 1, p. 79.

t ANops, Cav.-Bracteoles uone. Calyx 5-cleft. Stamineal columu divided at the apex into maus filaments. Cells of the ovary many, 1-ovuled, brauches of style as manj as the cells of the ovary, filiform, capitate, or truveate-stigmatose at the apex. Mature carpels forming a broad starlike verticil [from the outwardly projecting spurs]; separating from the axis, erostrate, diseepiments obliterated.Seed pendulous, or fixed horizontally : Hispid or tmoothish herbs with the babit of Malra. Leaves entire, hastately 3-lobed, or rarely dissected. Flowers violet or yellow, pedunculate, axillary, or in a fernirial raceme.-BENthaM \& HoOKer. 
Annual, stem erect, smoothish, or with a few scattering hairs; lower leaves small, roundish, crenate; stem-leaves long, petioled, thin, irregularly deeply cleft or strongly halbert-shaped; flowers axillary, sky-blue, $\frac{1}{2}-\frac{3}{4}$ in diameter (apparently resembling $A$. parviflora, Cav.). Calyx-lobes twice as long as the tube and distinctly bristly hirsute. Much against my will, I am obliged to retain this still as a variety, there being, so far as I can discover, little deviation from the typical form save in the size of the flowers. Camp Crittenden, Southern Arizona, at 5,200 feet altitude: (666.)

Var. Parviflora, Gray.-A low annual, 3-6' high, with a few ovate, crenate leaves on long petioles, was collected by Dr. Loew at some locality in Arizona. (165 a.)

Sida hedereacea, Torr. (in Pl. Fendl.p. 23). -Loew. New Mexico, Utah.

Sidd Lepidota, Gray (Pl. Wright. 1, p. 18).-A much-branching, prostrate species, from a descending root; leaves petioled, triangularcordate or somewhat hastate (quite variable), at first densely covered with a stellate pubescence below and scurfy above; peduncles axillary, bearing a single purple flower $8^{\prime \prime}$ in diameter. Carpels with a short, obtuse beak. Deer Spring, Ariz., 6,000 feet altitude. (188.)

Sida FILIFonmis, Moric. var.-Stems thin, wire-like, procumbent or ascending, with long, white hairs scattered along the stem and on the calyx ; petioles $3^{\prime \prime}-1^{\prime}$ long; leaves $6-12^{\prime \prime}$ long, lanceolate to oval, usually crenately serrate and more or less densely covered on either side with a short, stellate pubescence; calyx angular, lobes acuminate, nearly as long as the yellow petals; carpels moderately beaked. (665.) Sanoita Valley, Arizona. From Camp Bowie, I have a form which is much more hairy, has leaves larger in all respects, and almost beakless carpels. (470.) I have a full suite of specimens, and am unable to connect these forms. Hence, I believe they will, as we know them better, be regarded as distinct.

Spheralcea acerifolia, Nutt.- "Minutely roughish-tomentose, with a stellate pubescence; leaves 5-lobed, somewhat cordate; the lobes acute, toothed, unequally serrate; peduncles aggregated, terminal; carpels 12-14, pointless.-Stem much branched. Leaves $2-2 \frac{1^{\prime}}{2}$ long, and about the same in width: petioles about $\frac{1}{3}$ of the length of the lamina. Flowers 3-4 together at the summit of the branches. Bracteoles linear-lanceolate. 
Calyx cleft to the middle, segments broadly ovate, acute. Corolla an inch in diameter; purple (in dried specimens). Carpels pilose, dehiscing on the back from the summit to the base."-(T. \& G.) Utah.

Sphæralcea Fendleri, Gray.-San Francisco Mountains, Arizona and Utah. Taller, more branching, with larger leaves, and beaked carpels. New Mexico.-Forming a transition in some of its forms into the next. S. incana var. dissecta, Gray, now comes here.

Spimeralcea angustirolia, Spach, "var. foliis lanceolatis, inferioribus nunc hastato-sub-trilobatis," Gray.-Sanoita Valley, Arizona. (634.) The plant is erect, somewhat branching at the top; flowers arranged in contracted racemose panicles on the ends of the branches; leaves with the characteristic, eroded margins. A showy plant. My specimens were found growing in dry lava soil. (Those of Wright came from alluvial soil.)

Spheralcea Emoryi, Torr. (Pl. Wright. 1, p. 21).-Nevada and New Mexico. In Benth. and Hook. Genera Plantarum, we find Malvastrum and Spharalcea in different sub tribes and separated by eleven interpolated genera, yet considering the habit of Sphoralcea incana, var. dissecta, and the resemblance between S. Emoryi and Malvastrum Munroanum, coupled with the broader generalization of Bentham and Hooker under head of Spharalcea, as to the resemblance in habit, it may well be doubted as to whether the genera should not (in part at least) be thrown together. Colorado, New Mexico.

Hibiscus denudatus, Benth. (Bot. Voy. Sulph. p. 7, tab. 3). ( $\beta$. involucellatus, Gray, Pl. Wright. 1, p. 22.)-One or two feet high, with a few long, thin branches; leaves distant, $1-2^{\prime}$ long, $\frac{1}{2}-\frac{3 \prime}{4}$ ' wide, obtuse, irregularly crenate serrate, petioles $3-6^{\prime \prime}$ long; petals light purple, $8-10^{\prime \prime}$ long; bracts of the involucel setaceous, $9^{\prime \prime}$ long; entire plant, except the flower, densely covered with a stellate pubescence. (562.) Cienega, Ariz. (near Tucson).

Thurberia* thespesioides, Gray (Pl. Nov. Thurb. p. 308).-Perennial,

"Thurberia, Gray (PI. Nov. Tuurb. 308),-Bracteoles 3, cordate. Calyx truncate. Stamineal column produced above [almost to the apex] into many filaments. Ovary 3-celled with a few ovulea [6-8] in each cell ; style club-shaped at the apex. [Stigmatose on the three projecting angles.] Capsule losulicidal, 3-valved. Seeds obovoid, angular, minutely woolly, without albumen ; embryo conduplicate, ootyledons foliaceons, covered with black spots, much folded, almost including the inferior radical.-Tall, smooth berbs. Leaves entire or 3-parted. Flowers whito or rose colored, solitary on axillary or terminal peduncle8.-Gray in Bestuam \& Ноoker, Gen. PI. 1, p. 209. For a much more full description, see Gray, Pl. Tluurb. l. ., and for a good figure of this, the only species of the genus, see Bot. Mex. Bound. pl. 6. 
herbaceous, much branched, $5^{\circ}$ high; stem smooth; stipules falling away very early; leaves deeply 3-parted, with the divisions lanceolate, tapering into a long point; bracts three times as long as the truncate cyathiform calyx; petals very delicate rose color, $1^{\prime}$ long, obovate, woolly at the base on margins; style longer than the stamineal column. Young branches, petioles, leaves, and flowers sprinkled abundantly with black dots. (698.) Sanoita Valley, Southern Arizona.*

\section{S'IERCULIACE A. $†$}

Ayeniał pusilla, L., var. ramis erectis, foliis superioribus lanceolatis, Gray (Pl. Wright. 1, p. 24).-Perennial, with many thin, wiry stems from the thick, woody root; lower leaves ovate and somewhat irregularly serrate, upper ones irregularly serrate, twice as long, and lanceolate; flowers small, on reflexed, filiform pedicels, which are 2-4" long; capsule tuberculated and hairy. I would call attention to the fact observed by Dr. Gray (P1. Wright. 2, p. 24), that the anthers are trilocular. Judging from the statement in Bentham and Hooker, Gen. Plant. vol. 1, p. 225, this would also appear to be the usual rule in the genus. My specimens (569) from Southern Arizona correspond exactly with those obtained by Dr. Thurber at Van Horn's Wells, in what was then Sonora.

\section{LINEA.}

Linum Rigidum, Pursh, var. puberulum, Gray (Pl. Wright. 1, p. 25).Low, $2^{\prime}-4^{\prime}$ high, annual, branching from near the base; stems decidedly puberulent, leaves less so; leaves slightly imbricated, 3-6" wide, lower obtuse, upper slightly mucronate; vein inconspicuous; pedicel very slightly thickened at the top (not, however, forming a cupule); sepals acute, mucronate, glandular hispid on the margin; central vein prominent, and on outer (sepals) the lateral ones inconspicuous, a little longer ( $3-4^{\prime \prime}$ long) than the mature capsule (sepals about equal in length to the nearly undi-

* See Bentluam aud Ilooker, Gen. Pl. 1, p. 9×2.

† Sterculiaces differ from Malvacex by having 2-celled anthers, and from Trumace by the stamens, when definite in number, being alternate with the sepals, $i$. e., opposite to the petals, or when indefinite, united more or less at the base into a columu.

‡ Aycnia, L.- "Involucel none. Calvx 5-parted. Petals on long capillary claws, connivent over the stigma. Fertile stamens 5, alteruating with 1-2-8terile ones, their filaments united into a pedicellate cup. Style single. Stigma 5-angled. Capsule 5-lobed, 5-celled, localicidally 5-valved, the cells 1-seeded.-Low shrubly plants, with minnte axillary flowers. Capsule rough. Albumen none."-CinapMAN, Flora of Southern U. S. p. 59. 
vided style); filaments from an ovoid-triangular base, false partitions entire, membranous: stipular glands evident, (as they are in my specimens of the following species). My specimens are very slightly glaucous. (15.) Gravel hills back of Santa Fé, N. Mex., at 7,050 feet altitude.

Linum Berlandieri, Hook.-Erect, annual, stem distinctly striated, slightly puberulent; lower leaves obtuse, upper slightly mucronate, longer on the average than in the preceding species, which it so closely resembles that I know of no way of distinguishing them, save by the character of the false dissepiments (as indicated by Dr. Engelmann in Pl. Wright. 1, pp. 25 and 26), which, in L. Berlandieri, are membranous in the upper and inner half. Under head of L. Berlandieri, Dr. Engelmann alludes to a small form collected by Wright on the San Pedro River, which is apparently kept apart from $L$. rigidum, var. puberulum (collected on the Cimarron), only by the character of the false partition in the ovary, which is decidedly that of $L$. Berlandieri. I have the precise form (from Santa Fé) he alludes to (so far as can be determined from description), and have, from its partitions and ovate-triangular-based filaments, been obliged to put it under $L$ rigidum, var. puberulum. Single specimens found by Dr. Loew at Rancheiro Springs, Arizona.

Linum perenne, L.-Widely diffused over Nevada, Utah, Colorado, Arizona, and New Mexico, where it has been obtained by the Expedition; extending, besides, from the Arctic Ocean to Mexico and west to the Pacific.

MALPIGHIACE.E.*

Aspicarpa $\dagger$ Longipes, Gray (Pl. Wright. 1, p. 37).--Stems several,

"MaLpighices,-_Calyx 5-merous, persistent, segments usnally biglandular. Petals 5, usually nuguiculate, isostemouons, or diplostemonous, inserted either on the receptacle or on a hypogynous or perigynous disk. Stamens inserted with the petals, usually monodelphous, when several are antherless. Ovary composed of 3 or 2 carpels, connate, or distinct at the top, of 3 or 2,1 -ovnled cells, ovule nearly orthotropous. Fruit a drapo or of 3-2 cocci. Embryo exalbuminous. Stem woody."-LE MAovt \& Decaisse (Euglish edition).

† Aspicanpa, Lagas.-Flowers dimorphous. Normal ones:-Calyz 5-parted, with 10 glands. Petals elawed, fimbriate-ciliate. Stamens 5, 2 perfoct, 3 without anthers or the middle one of them with a perfect anther, and tho lateral ones with imperfect anthers. Ovaries 3, connate to the axis, style central, upex obliquely truncate. Fruit i [See speeific description.] Abnormal floucers:-Calyx without glands. Petals none. Anthers single aud rudimentary. Ovaries 2, witbout styles. Nut solitary, either crestiess, or with 1-3 slightly prominent dorsal crests, irregularly pyramidal 3-angled. Sced compressed, subreniform, testa membranous, cotyledons obovate, flattish, curved.-Sleuder, erect, branching sbrubs, with tho branchlets frequently covered with appressed hairs. Leaves opposite, entire, frequently silky, stipules inconspicuous. Normal llowers mostly umbelled, termmal or axillary, rarely soli ‘ary, vellow ; abnormal, uxillary, вolitary, very вmall.-Вемтнам \& Ноокег. 
from a woody root, very slender and wiry, decumbent, somewhat hairy (with the characteristic hairs of the order); leaves on short but distinct petioles, slightly cordate at base, ovate-oblong, very slightly mucronate, pale and veiny beneath, $9-18^{\prime \prime}$ long. Normal flowers with 10 large glands on the base of the calyx-lobes; petals clawed, glandular fimbriate above; stamens monodelphous at base only, perfect anthers 3 , imperfect (on filaments about the same length) 2 ; "fruit of a single carpel, of nearly the same form as in $A$. Hartwegiana, but more even, with rounded and only slightly margined sides" (Gray); three or four together terminating filiform pedicels on foliaceous or bracted peduncles, or on slender pedicels from the axils of the leaves. Abnormal flowers on slender peduncles, which are terminated by a pair of bracts $4^{\prime \prime}$ long and half as wide, from between which the short pedicel and its flower arise. (627.) Sanoita Valley, Southern Arizona.

\section{ZYGOPHYLLACEA.*}

Tribulus $†$ (Kallstremia) maximus, L.-Leaves longer than the pedicels; leaflets, 3-4 pairs, oval, hairy on the lower surface; carpels 10 , slightly gibbous below, tuberculate; style $5^{\prime \prime}$ long; sepals lanceolate, tapering into an acute apex, $\frac{2}{3}$ as long as the petals. San Carlos, Ariz. (777.)

Tribulus (Kallstremia) grandiflorus, Benth.\& Hook. (Kallstromia grandiflora, Torr. in Pl. Wright. 1, p. 26.) -Stem clothed with long, brown, spreading hairs; leaves shorter than the older peduncles, leaflets $4-5$ pairs, oblong, slightly falcate; sepals lanceolate-linear, with long, attenuated tips; petals nearly or quite as long as the sepals; carpels less tuberculated on the

*Zygophyllacex.- "Calyx 4-to 5-meroes, generally imbricate. Petals bypogynous, usually imbricate. Stamens usually double the number of the petals, bypogyuous; filaments usually witb a scale inside. Ovary several-celled. Fruit a loculicidal eapsule, septicidally dividing into cocci. Embryo exalbuminons, or enclosed in cartilaginous albumen.-Scentless plante. Leaves opposite, pinnate, stipulate."-Le MaOut \& Decarsne (English edition).

† Tribulus, Linn.-Sepals 5, deciduous, or persistent, imbricated. Petals 5, fugacious, spreading, imbricated. Annular disk 10-lobed. Stamens 10, inserted on the base of the disk, 5 opposite to the petals exterior and usually somewhat longer than the others, 5 alternate with a gland outside of tbe base, filaments filiform and naked. Ovary sessile, with appressed hairs, 5-12-lobed, 5-12-celled, the cells opposite the petals frequently 3-5-locellate by transverse partitions; style short, pyramidal or filiform; stigmas 5-12; ovules 1-5 in each cell, superposed. Fruit 5-angled, indehiscent. Seeds obliquely pendalous, one in each cell or cellule, testa membranous; embryo exalbuninous, cotyledons oval, radiclo short. - Loosely branching herbs, of cen silky-bairy, and with prostrate branches. Leaves $\mathrm{k}$ tipulate opposito, sometimes alternate by abortion of one, abruptly pinnate. Flowers solitary, pseudo-axillary, pedunculate, white or yellow.-BenthaM \& HoOKer. 
back than in the preceding species, with which it contrasts by its larger flowers, more hispid stem, and more and narrower leaflets. Camp Grant, Ariz. (442.)

Larrea Mexicana, Moric. (L. glutinosa, Engelm.)-(321.) Valley of the Gila, Arizona. (Tab. iii, Torrey, in Emory's Report.) This shrub is especially common on the hills bordering the Gila; also on the sandy wastes adjacent to Tueson and Camp Lowell in Arizona, even imparting its strong odor to the air.

\section{GERANIACEA.}

Geranium Richardsonit, Fisch. \& Mey.-Very closely allied to $G$. maculatum, L. ; differing only in being more smooth, styles hairy and less connate, filaments pilose instead of ciliate, and seeds more delicately reticulated. (408.) Mount Graham, Arizona, at 9,200 feet altitude. Also a more white-flowered and more pilose form (234) from Willow Spring, Ariz., at 7,195 feet altitude. Nevada and Utah; Colorado (758).

Geranium Fremontir, Torr. (Pl. Fendl. p. 26).-Much branched, $6^{\prime}-2^{\circ}$ high, pubescent or glabrous; upper stem-leaves $3-5$-cleft, truncate at base, lower broadly cordate; root-leaves 7 -cleft; peduncles $1-2^{\prime}$ long; pedicels in pairs, 1-1 1 12 long; sepals oval, with a short, thick awn; fruiting pedicels sometimes diraricate, or deflexed; petals obovate, rarying from light to deep purple, $1^{\prime}$ in diameter, villose on the veins; filaments at base pilose-ciliate; styles united below; seeds somewhat reticulated. Plant forms branching, luxuriant tufts. Hard to limit by a description, yet usually readily recognized. Sanoita Valley, Arizona. So. 279 , from Rocky Cañon, Arizona, I had doubtfully assigned here. Mr. Watson assures me, that, though usually placed under G. caspitosum, it is really G. Eremontii. It has the stamens of caspitosum, and is besides quite smooth.

Geranium caspitosum, James-Peremnial, $4^{\prime}-1^{\circ}$ high ; stems branching from the base; these, with the petioles and pedicels, retrorsely pilose or pubescent; peduncles several times longer than the $1-2^{\prime}$ long pedicels; flowers ahout an inch in diameter, deep purple. Readily distinguished from the preceding species by its stamens, which are almost as long as the petals, and during flowering are outwardly recurved. Santa Fé. 
Some forms resemble G. Fremontii closely, South Park, Colorado, (759), Utah.

Erodium cicutarium, L. Her.-Santa Fé, N. Mex. (36 a. $)$

Oxalis violacea, L.-Mount Graham, Arizona, at an altitude of 9,250 feet. (437)

\section{RUTACEA.}

Canotia* holocantha, Torr. (in Pacific R. R. Rep. iv, 68). Benth. and Hook. 1, 616.-A much branched, leafless tree, $20^{\circ}$ high and trunk $1^{\circ}$ in diameter; branchlets yellowish-green, delicately striate; sparingly dotted with very minute brown scales, which represent reduced leaves; flowers white or yellowish white; pedicels articulated; bracts small and scale-like; minute cil-glands sparingly seen on the bracts, sepals, and petals. Gila Valley, Arizona. (323.) Plate I. $\dagger$

From Camp Bowie, Arizona, I have (499) a Ptelea, probably angustifolia, Benth.

\section{CELASTRINE E.}

Pachystima Mrrsinites, Raf.-Utah, 5,000 to 7,000 feet altitude. Quite recently, the indefatigable $\mathrm{Mr}$. Canby has brought to light a second species of this genus (P. Canbyi, Gray), in Giles County, Virginia. "While the original $P$. Myrsinites occurs plentifully in most wooded districts from the

* Canotia, Torr.-"Flowers hermaphrodite. Calyx small, 5-lobed, persistent; the broad lobes imbricated in restivation. Petals 5, hypogyoous, oblong, very obtuse, at base with a broad insertion, imbricated in sostivation, with a rather prominent midrib inside, deciduous. Stamens 5, hypogynous, opposite to the calyx lobes: filaments subulate, somewhat shorter than the petale, persistent: anthers oblong-cordate, introrse, affixed to the filaments in the acute apex of a deep sinus, apiculate with a small mucro; cells inwardly longitudinally debiscent. Dried pollen becomes 3-horned when moistened. Disk none. Ovary placed on a gynobase (at first thicker than itself ), 5-celled, the thick style at length elongating : stigma small, slightly 5-lobed; cells of the ovary opposite to the petals. Ovules in the cells most f equently 6, subhorizontally inserted in two series in the inner angle [amphitropons]; micropyle inferior. Capsule ovate-fusiform, somewhat woody, covered with a delicate, somewhat fleshy epicarp, 5-culled, 10-valved at the apex (at first septicidal and later loculicidal), terminated by 10 split portions of the persisting style; columolla none. Seeds 1-2, filling the cell, ascending, subovate, flattened; testa subcoriaceous, thickly papillulose, produced below iuto a broal membranous wing somewhat longer than the nucleus. Embryo straight, in a thin layer of fleshy albumen; cotyledons oval, flat; the shortish radicle inferior." My own epecimens showing only the flowers and immature fruit, I have been obliged to quote the above from Dr Gray's complete description, recontly published in Proc. Amer. Acad. xii, pp. 159-160.

† Branch; natnral size. Fig. 1. A cross section of a flower. Fig. 2. An open flower. Fig. 3. A longitudinal section of flower. Fig. 4. An inside view of stamen. Fig. 5. An outside view of stamen. Fig. 6. The young fruit; petals fallen and filanents remainirg. Fig. 7. A vertical section throngh a young ovary. Fig. 8. A young ovnle. Fi . 9. A vertical section of mature fruit. Fig. 10. A cross section of fruit. Fig. 11. A seed. Fig. 12. A diagonal eection of a seed. All except tho brauch maguificd about livo diameters.

(6) BOT 
Rocky Mountains to the Pacifie, in Northem California and Washington 'Territory, this is only known at one station in the Alleghany Mountains, and makes an addition to the list of those few genera (such as Boykinia and Calycanthus), which are divided between Eastern and Western North America."-(Gray, Proc. Am. Acad. viii, pp. 623-624.)

\section{RHAMNEF.}

\section{ZizypuUs* Lycioides, Gray, var. canescens, Gray.-A much branched} shrub, 4-5 high; younger branches covered with a light gray powdery substance, which is readily scraped away, leaving the green epidermis exposed beneath; leaves oval, obtuse, pubescent (especially beneath); petioles 2-4" long; spiny branches $\frac{1}{2}-1^{\prime}$ long, thick, terminating abruptly in a point. More or less leafy; flowers greenish. Valley of the Gila, Arizona, at 3,080 feet altitude. (331.)

Karwinskia † Humboldtiana, Zucc. (Gray, Pl. Wright. 1, p. 32).Shrub from $2-12^{\circ}$ ligh, leaves oval and beautifully penninerved [Flowers not seen.] Drupe ovoid, 4-5" long, pointed with the remains of the style, cup or disk-like calyx terminating the pedicel after the drupe has fallen. Plant appears to vary much in the shape of the leaves and in the number of flowers in the axillary clusters. Arizona.

Rhamnus crocea, Nutt. (T. \& G. Fl. N. Am.).—"Low, branches

- Zizyrius, Jus8.-Calyx 5-cleft, tube broadly obconical, lobes triangular-ovate, acute, spreading, carinate within. Petals 5 (rarely 0 ), booded, deflexed. Disk flat, 5-angled, margin free. Stamens 5, iucluded or longer than the petals, filaments subulate. Ovary inmersed in the disk and at the base coufluent with it, 2-, rarely 3-, most rarely 4-celled; styles 2-3, conical, free or counate, divergent, stigmas small, papillose. Drupe fleshy, globose or oblong, putamen woody or bony, 1-3-colled, 1-3seeded. Seeds plano-convex, testa thin, fragile, acd smooth, albumen little or none; cotyledons thick; radicle short.-Shrubs or trees decumbent, or with many snall branches, often with strong, hooked spines. Leaves sub-distichons, alteruate, petiolate, coriaceous, entire or crenate, 3-5-nerved. Stipules both spiuescevt or one cadncous, hooked or straight, c5mes short, axillars, few-flowered. Flowers small, greenish. Fruit often edible.-Bentram \& Ноокеr.

$\nmid$ Karwinsки, Zuco.-Calyx 5-cleft, tube hemispherical or turbinate, acute lobes 3-angled, keeled or with the keel produced within and above into a spur. Petals 5, short-clawed and hooded. Stamens longer thau the petals, filuments subulate. Disk lining the tube of the calyx, delicate limb free. Ovary enb-globoso, immersed in the disk, frie, 2-3-celled, septa parting in the middle, often attenuated (tho ovary) inte a triangular style, with the apex 2-3-lobed, stigmas obtuse, papillose; ovules 2 in ear h cell, jaralicl, curved doivnward. Drupe sub-globnse or ovoid, apiculate with the persistent style, surrounded at base by the calyx, putamen 1-2-celled, each cell 1-seeded. Seeds ercet, obovate, testa membranons, dark-verrucone, raphe oluvated, albumeu in a thin fleshy stratum adberent to the testa ; cotyledons oval, fleshy; radicle very short.-Small trees and sirrubs. Leaves sub-opposite, petiolate, oblong, entire, penninorverl, pollucidly panctulate. Stipules membranous, deciduous. Flowers axillars, macenose wr cymose. Cyues faneiculate,-Bextian \& Heokir. 
spinescent; leaves thick, evergreen, obovate, $2_{2}^{\prime}$ long; petiole 1-2" long, glandularly denticulate; flowers diœcious, apetalous, styles distinct above. A thorny shrub with yellow wood, imparting its color to water." Arizona. I have not seen the plant.

Ceanothus Fenderi, Gray.-Shrub, with stiff, and often spine-tipped, gray branches; leaves thickish, tomentose pubescent beneath, smoother on upper surface, lanceolate to oval, 5-12" long, usually cuneate at base, petioles $1-3^{\prime \prime}$ long; small white flowers in paniculate racemes terminating the branches. New Mexico (143). Camp Apache, Ariz. (257), at 4,900 feet.

\section{AMPELIDE无.}

Vrtis zestrvalis, Michx., var.?-" Resembling a common Texan and New Mexican form; perhaps $V$. Arizonica, Engelm. Arizona."-S. WATSON.

Ampelopsis quinquefolia, Michx. (Vitis, Bentham \& Hooker, Gen. Plant.)-New Mexico. (110.)

\section{SAPINDACE A.}

Sapindus* Marginatus, Willd.-Tree $10-30^{\circ}$ high; leaves $4-8^{\prime}$ long, leaflets thickish, shining, plainly penninerved, lanceolate, tapering into a long point, inæquilateral, somewhat falcate; flowers in compound terminal and axillary panicles; fruit globose, $6^{\prime \prime}$ in diameter. Arizona, in the dryer portions. (301.) "Soapberry."

Acer glabrum, Torr.-Mountain streams of Colorado. The name $A$. tripartitum, Nutt., would have been much more appropriate. (1.)

Acer grandidentatum, Nutt--(303.) Ash Creek, Arizona, at 4,684 feet altitude. Utah.

* Sapindus, Linn.-Flowers polygamons, regnlar. Sepals 4-5, 2-seried, imbricated. Petals 4-5, naked or with 1-2 glabrous or villous scales within, produced into a claw above. Disk complete, annular or elevated. Stamens 8-10 (rarely 4-7 or more), filaments free, frequently pilose; anthers versatile. Ovary entire or 2-4-lobed, 2-4-celled; style terminal, stigma 2-4-lobed; ovules solitary in each cell, ascenting from the base of the interior angle. Fruit fleshy or coriaceous, with 1-2, (rarely) $3-4$ cocri, which are oblong or globose and indebiscent. Seeds usually globose, destitute of an aril, testa crut taceous or membranons; embryo straight or curved, cotyledous thick, radicle short.-Trees or shrubs. Jut wes alternate, without stipnles, simple, 1-foliate, or abruptly pinnate, with the leaflets entire, or rarely serralt Racemes or panicles either termiual or axillary. Fruit dry or baccate.-BExтнам \& Hoокеi. 
Negundo aceroides, Monch.-Santa Fé, N. Mex., along water-courses at 7,044 feet altitude. (20.) Arizona and Utah.

\section{ANACARDIACEE.}

Rhus virens, Lindh. (Pl. Lindh. 2, p. 159).-Shrub, 4-6 ligh, with bark much resembling Kalmia latifolia; leaflets (in my specimens) 3-5, rigidly coriaceous, inæquilateral (terminal one largest), entire and under surface thickly sprinkled with black dots; sepals and subtending bracts tinged with red, petals white, flowers in a thyrsoid panicle, which is shorter than the leaves; "drupe red, hairy, putamen lenticular and smooth." Rocky ledges on east side of Santa Rita Mountain, Arizona, at 5,700 feet altitude. (645.) Resembling in all respects the specimens obtained by the Mexican Boundary Survey, save that in the Boundary specimens there are 7-9 leaflets.

Rhus glabra, L.-Chiricahua Agency, Arizona, at an altitude of 5,310 feet. (533.) Utah.

Rhus aromatica, Ait., var. trilobata, Gray. (Rhus trilobata, Nutt.)(203.) Willow Spring, Ariz. Utah.

Rhus integrifolia, Benth. \& Hook. (Styphonia, Nutt.)-A small, much branching tree, with oval, obtuse, entire leaves, which are $1^{\prime}$ or more long, petioles $4^{\prime \prime}$ long; sepals and petals reddish; hairy drupes the size of a pea. Arizona. I have not seen specimens.

Rhus Toxicodendron, L.-Willow Spring, Ariz., at 7,195 feet altitude. (254.)

\section{LEGUMINOSE.}

BY SERENO WATSON.

Suborder I. PAPILIONACEAs. Flowers irregular, perfect. Perigynous disk lining the bottom of the campanulate or tubular 5-eleft or toothed caly $\mathrm{x}$ and bearing the petals and stamens. Yetals 5 (rarely fewer), imbricated, the upper one larger and exterior. Stamens 10 (rarely 5), diadelphous (9 aud 1), or monadelphous, or rarely distiuct. Seeds without albumeu. Radicle inflexed. Leaves simple or simply compound.

\section{Stamens distinct.}

- Leaves digitately 3.foliolate; stipules conspicuous: pod flat, 2-valved.

Tinermopsis. Perennial herb. Flowers yellow, racemose. Pod linear, straight, several-seeded. 
** Leares unequally pinnate; stipules small or none: pod turgid, mostly indehisceut and few-seeded.

Sopmora. Perenuial herb. Flowers white, racemose. Pod terete, moniliform, few-seeded.

Aмоrрна. Șlirub, glandular-dotted. Flowers purple, racemose; wings anıl keel wanting: stamens monadelphous at base. Pod 1-2-seeded.

Parryella. Glandular shrub. Flowers spicate: petals none. Pod 1-seeded.

\section{Stamens monadelphous or diadelphous.}

* Authers of two forms : stamens monadclphous: leares digitate, of 3 or more entire leaflets: pods dehiscent. Herbs or shrubby, not glandular-dotted nor climbing.

Crovalaria. Calșx 5-lobed. Pod inflated. Leaflets 3.

Lupinus. Calyx 2-lipped. Pod flatteued. Leaflets 5 or more.

** Anthers mostly uniform. Not climbing.

†Leaflets 3 (rarely digitately 5 or 7 ), toothed: stamens diadelpbous: pods small and mostly included in the calyx (strongly coiled in Melilotus).

Medicago. Flowers in long axillary racemes or spikes; petals free, decidu ous. Style filitorm. Pod small, wrinkled.

Melilotus. Flowers as in Medicago. Style subulate.

Trifolium. Flowers capitate ; petals persistent, united with the filaments.

† Leaves pinnately 3-many-foliolate (very rarely digitate or simple in Hosackia); leatlets entire: pod not articulated.

‡ Flowers umbellate or solitary, on axillary peduneles: stamens diadelphous: herbage not glandular-punctate.

Hosackia, Herbaceous or shrubly. Petals yellow or jellowish, turning brownish; claw of the standard remote from the rest.

\# Flowers spicate or racemose: stamens diadelphous: herbs not glandularpunctate (except in Glycyrrhiza): pod dehiscent.

Tephrosia. Peduncles terminal. Standard hairy. Pod flat, 1-celled.

IndigoferA. Peduncles axillary. Standard hairy. Pod linear, terete, 2 celled. Connective of the anthers gland-tipped.

As'rragalus. Peduncles axillary. Standard naked; beak of the keel not erect or recurved. Pod often bladdery or turgid, 1-celled, or more or less 2-celled by the intrusion of the dorsal suture.

OxyTRUPIs. Like Astragalus, but the keel with an erect or recurred beak, and pod partially 2-celled by intrusion of only the rentral suture.

Glycyrnhiza. Like Astragalus, but anthers confluently 1-celled, pod armed with prickles and 1-celled, and leares more or less glaudular and punctate.

$\ddagger \ddagger$ Flowers spicate or racemose: stamens mostly monadelphous or distinct: pods iudehiscent, small and few-seeded. Herbs or shrubs, mostly glandular punctate. 
Psorarea. Perenuial herbs, with 3-foliolate leares aud axillary spikes. Stamens monadelphous or somerwhat diadelphous. Pod 1-seeded.

Amorpin. Shrubs, with pinnate leares and terminal racemes. Wings and keel wanting. Stamens united only at base. Pod 1-2-seederl.

Petalostemon. Herbs, with pinnate leaves and terminal spikes. Stamens 5, monadelphous, bearing 4 of the petals on the tube. Pod 1-seeded.

Parryella. Shrubby, with pinuate leaves and terminal spikes. Stameus 10, distinct. Petals none. Pod 1-seeded.

Dales. Slurubs or herbs, with pinnate leaves and terminal spikes or heads. Stamens 10, monadelphous, the petals jointed to the tube. Pod 1-2-seeded.

t † † Leaves pinnately 3-mans-foliolate (digitately 2-4.foliolate in Zornia); leaflets entire: pod transversely 2-several-jointed, the joints indehiscent and 1-seeded. Herbs.

Hedrsarum. Leaflets sereral, stipellate; stipules scarious. Stamens diadelphous. Perennial, with axillary racemes.

Zornia. Leaflets 2 ; stipules herbaceous. Stamens monadelphous. Flowers spicate, each solitary and sessile between a pair of couspicuous bracts. Annual.

Desmodrum. Leaflets 3 ; stipules dry and striate. Stamens usually monadelphous. Racemes simple or panicled.

* * Anthers uniform. Herbs, climbiug by tendrils or twiuing, sometimes prostrate: stamens diadelphous : pod flat,2-ralved: racemes axillary (or flowers axillary in Cologania and Rhynchosia).

+ Leares abruptly pinnate, terminated by a tendril: seed-stalks broad at the hilum.

Vicra. Stamen-tube oblique at the mouth. Style filiform, bairy around and below the apex.

LATHyRUs. Stamen-tube nearly truncate. Style dorsally flattened, usually twisted half around, hairy on the inner side.

f † Twining or prostrate herbs, with 3 -foliolate leaves.

$\ddagger$ Flowers not jellow : seeds several.

Cologania. Calyx tubular. Style naked. Bracts persistent.

Galactis. Caljx 4-cleft. Keel nearly straight. Style naked. Bracts minute or caducous.

Phaseolus. Calyx short. Keel strongly incurved and standard reflexed. Style bearded. Bracts minute or caducous.

$\ddagger \ddagger$ Flowers yellow, axillary : seeds 1 or 2.

Rnynchosia. Flowers small. Style naked. Leares often resinous-dotted.

SUBORDER II. CASALPINEAE. Flowers more or less irregular, perfect. Perigynous disk lining the base of the short calyx-tube. Petals 5 , imbricated, the upper one incladed. Stamens 10 or fewer, distinct. Seeds sometimes albuminous. Radiele not inflexed.

- Leaves bipinnate; leaflets small : authers 10, versatile, dehiscing longitudinally : calyx slightly imbricate or valvate. 
Horfmanseggia. Low herbs or woody at base. Pod flat. Seeds without albumen.

Parkinsonia. Somewhat spinescent slurubs or trees. Pod more or less torulose. Seeds albuminous.

* Leaves simply and abruptly pinnate: anthers 10 or fewer, fixed by the base, opening by terminal pores: calyx imbricated.

Cassia. Herbs or woody at base. Pods rather thick or flat. Seeds albuminous.

Suborder III. MIMOSEA. Flowers regular, small, in spikes or heads, perfect or polygamous. Calyx and corolla valrate, 4-6-toothed or divided. Perigy. nous disk none. Stamens as many or twice as many as the lobes of the corolla, or numerous, hypogynous. Seeds mostly without albumeu. Radicle not inflexed. Leaves usually bipinnate.

- Stamens twice as many as the petals or just as many : pollen-grains numerous.

Prosopis. Shrubs or trees, more or less spiny. Petals distinct or becoming so. Flowers greenish, in heads or cylindrical spikes. Pod straight or coiled, at length thick and pulpy within.

Desmanthus. Herbs, unarmed. Flowers purplish, in globose heads. Pod flat and thin, not jointed, 2-valved.

Mimosa. Herbs or shrubs, armed with prickles. Flowers in heads or short spikes. Valves of the pod separating from the persistent margius, entire or jointed.

* Stamens numerous : pollen-masses 4 to 6 in each anther-cell.

ACACIA. Shrubs or small trees, usually armed. Flowers capitate or spicate, sellow. Stamens distinct. Pod flat, 2-valved.

Calliandra. Herbaceous or shrubby, nuarmed. Flowers capitate. Stamens united at base into a tube, long-exserted, purple or white. Pod dehiscing elastically from the apex downward.

Thermopsis* montana, Nutt. (Torr. \& Gray, Fl. i, 300). (T. fabacea, DC., var. montana, Gray.)—Somewhat silky-pubescent, at least on the under surface of the leaves: leaflets oblong-obovate to narrowly oblong, obtuse or acutish, smooth above, one to three inches long; stipules ovate to lanceolate, exceeding the petioles: bracts oblong to linear-lanceolate: pod linear, straight, erect, pubescent, two or three inches long and 10-12seeded, on a stipe shorter than the calyx-tube.-On stream-banks in the mountains, from Wyoming Territory to New Mexico and westward to Oregon; Northern Nevada, 1871; Denver, Colo. (201).

*Thermopsis, $R$. Brown,-Calox campanulate, equally cleft to the middle, or the two upper teeth united. Standard broad, shorter than the straight wings, the sides reflexed. Stamens distinct; anthers uniform. Pod coriaceous, linear to oblong-linear, flattened, few-many-seeded, nearly sessile.-Stont perennial herbs, with digitately 3 -foliolate leaves on short petioles ; leaflets entire and stipules foliaccous; fluwers large, yeliow, in terminal racemes, with persisteut herbaceous bracts. 
Sophora* serices, Nutt. (Gen. i, 280).-Appressed silky-pubescent: stems licrlsaceous, from a peremnial ruming rootstock, erect, a foot high or less, branching: leaflets six to ten pairs, oblong-obovate, obtuse or retuse, mlabrus above, two to six lines long; stipules linear or wanting: racemes shortly peduncled, rather loose, short ; bracts subulate, somewhat persistent, about equalling the pedicels: calyx 5-toothed: petals white, four to six lines long; the standard longer, recurved, and with a narrow claw: pods pubescent, more or less stipitate, thin-coriaceous, scarcely dehiscent, 1-3seeded (about 6-ovuled), an inch or two long.-Colorado to New Mexico, frequent; collected at Kit Carson and Apex, Colo. (238), and at McArthy's Ranch, N. Mex. (98).

Crotalaria lupulina, DC. (Prodr. ii, 133).-Annual and finely pubescent or glabrate: stem slender, erect or ascending, one-half to two feet high, branching: leaves digitately 3 -foliolate; leaflets cuneate-oblong, obtuse, mucronulate, smooth above, a half to one and a half inches long, exceeding the petioles; stipules setaceous: peduncles terminal and opposite the leaves, loosely flowered: bracts minute: pedicels recurved: calyx two lines long or less: petals three to six lines long, the keel with a long straight beak: pod oblong, half an inch long.-From New Mexico and Arizona to Northern Mexico, and also in Cuba; collected by Rothrock, in Arizona, at Camp Grant (443), Chiricahua Agency (534), and Camp Crittenden (684). Grisebach refers the species to C. pumila, Ortega.

Lupinus Sitgreavesir, Watson (Proc. Am. Acad. viii, 527).-Perennial, herbaceous, slender, leafy and branching, about two feet high, more or less silky-villous; pubescence of the racemes short and spreading: leaflets 7 to 9, narrowly oblanceolate, usually glabrous above or nearly so, equalling the petioles: raceme open, shortly peduncled: flowers rather large, light blue, on slender pedicels: calyx broad, not spurred: standard naked; keel usually ciliate: pod 5-seeded-In the mountains from the Southern Sierra Nevada to Southern Colorado and New Mexico; San

- Sophora, Linn.-Caly x campanulate, with short equal teeth. Petals nearly equal; standarl broad. Stamens distinct; authers nniform. Pod thick or coriaceous, terete, stipitate, mostly indebisceut, constricted between the several sub-globose seeds and usually necklace-Jilie.-Trees, shrubs, or herbs, with unequally pirnate leaves and eatire leaflets; stipules small or none; flowers in terminal racemes. 
Francisco Mountains, 1871; Willow Spring, Ariz., Loew (1115); Rocky Cañon, Ariz., Rothrock (285). An apparently variable species of somewhat uncertain limits.

Lupinus farviflorus, Nutt.-In the Sierra Nevada and northward to the Columbia, and also in the Wahsateh Mountains, where it was collected in 1871 .

Lupinus Laxiflorus, Dougl.-From Washington Territory to Nevada and Utah; in the Wahsatch, 1871.

Lurinus argenteus, Pursh.-Perennial, herbaceous, with short appressed silky pubescence, the numerous stems rather low, leafy, much branched, often decumbent at base: leaflets 5 to 8 , narrowly oblanceolate, smooth above or nearly so, equalling the short petioles: racemes nearly sessile, short: flowers small, blue or whitish, on slender, usually short pedicels : calyx broad, somewhat gibbous : petals naked or nearly so : pods 3-5-seeded.-Oregon to Montana ; at Mosquito Pass, Colo., Wolf (196).

Var. Decumbens, Watson, l. c. 532, rather stout, with denser racemes, and var. ARGoPHyLL $\Lambda$, Watson, l.c., more silky-pubescent, and nearly equally so on both sides of the leaves, the flowers larger, and the calyx decidedly spurred, are both very common in the Rocky Mountains from Montana to New Mexico. The first was collected near Gray's Peak by Wolf (197, 202), at Rancheria Springs, Ariz., Loew (199), and at Sulphur Springs, Southern Arizona, Rothrock (543), the latter specimens closely approaching the typical form; var. argophylda at Santa Fé, N. Mex., Rothrock $(1,59)$.

Lupinus holosericeus, Nutt.-Much resembling the latter variety of the last species, but more densely appressed white-silky throughout, the standard hairy upon the back, and the keel ciliate.-On the eastern side of the Sierra Nevada from Oregon to Southern Nevada and Utah, where it was collected in 1871 .

Lupinus Leucophyluus, Dougl.-From Oregon to Utah and New Mexico; collected in the Wahsatch in 1871.

LuPinus C正Pitosus, Nutt.-Perennial, dwarf, the stems very short and cespitose: pubescence appressed-villous: leaflets 5-7, oblanceolate, several times shorter than the petioles: racemes sessile, short, dense: bracts long, 
persistent: flowers small, purple, nearly sessile: standard narrow; keel ciliate: pod very short, 3-4-seeded.-From Wyoming to Colorado and Utalı; on Blue River, Colorado, Wolf (200).

Lupinus pusillus, Pursh.-From the Upper Missouri to the Columbia and southward through the interior; Denver, Wolf (198).

Lupinus Kingi, Watson (Proc. Am. Acad. viii, 534). (L. Sileri, Watson, same, $\mathrm{x}, 345$.) - Resembling the last, but more slender and villous with soft white hairs: racemes very short, few-flowered, on long slender peduncles: pods and seeds smaller--Utah and Colorado; at Loma, on the Rio Grande, Wolf (195).

Medicago sativa, Linn.-Santa Fé, N. Mex., naturalized in the Plaza, Rothrock (65). Known as "Alfalfa".

Melilotus Parviflora, Desf. " "Sweet Clover."-Camp Lowell, Ariz., Rothrock (710, 716).

Melilotus alba, Lam.-Collected in Utah, 1871.

Trifolium megacephalum, Nutt. (Gen, ii, 105).-Perennial, very stout, rather low, somewhat villous: leaflets 5 to 7 , obtuse, nearly an inch long; stipules ovate-oblong: flowers rose-colored, sessile in very large raked terminal heads: calyx-teeth filiform, plumose: ovary smooth, 6ovuled.-From Washington Territory to Northeastern California and Nevada; Diamond Range, Northern Nevada, 1871.

Trifolium longipes, Nutt. (Torr. \& Gray, Fl. i, 314).-Frequent from the Rocky Mountains to the Pacific; Mogollon Mesa, Loew (179).

Trifolium nanum, Torrey (Ann. N. Y. Lyc. i, 35, t. 3).-In the Rocky Mountains and Wahsatch; South Park, at 13,000 feet altitude, Wolf $(175,874)$.

Trifolium Parryi, Gray (Am. Journ. Sci. 2d ser. xxxiii, 409).-In the Rocky Mountains and Wahsatch; at Twin Lakes, in South Park, Wolf $(177,184)$.

Trifolium dasyphyllum, Torr. \& Gray (Fl. i, 315).-In the Rocky Mountains and Wahsatch; on Gray's Peak and in South Park, Wolf $(182,183)$.

Trifolium involucratum, Willd.-Annual, glabrous, the ascending stems often a span high or more: leaflets usually oblanceolate, acute, a 
half to an inch long: flowers purple or rose-colored, half an inch long, sessile in close heads, involucrate: involucre deeply lobed, the lobes laciniately and sharply toothed: calyx-teeth thin, long and narrow, entire: ovules mostly 5 or 6.-Var. Heterodon, Watson (Proc. Am. Acad. viii, 130), with usually larger heads and broader leaflets; some of the calyx-teeth setaceously cleft.-A very common species west of the Rocky Mountains, ranging from British America to Mexico, the variety nearer the coast. The typical form was collected in the valley of the Upper Arkansas, Colorado, Wolf (176); at Santa Fé, N. Mex., Rothrock (63); in Western New Mexico, Loew ; at Zuñi Village, N. Mex., Rothrock (172); at Willow Spring, Ariz., Rothrock (229). A form with the small involucre cleft nearly to the base was found in Zuñi River Cañon (178), and on Mount Graham, Rothrock (432).

Trifolium monanthum, Gray (Proc. Am. Acad. vi, 523).-Annual, very slender, low and often dwarf, more or less villous : leaflets obcordate to oblanceolate, mostly retuse : flowers 1 to 4 , white or purplish, with a very small 2-3-parted involucre, much longer than the calyx: calyx-teeth not rigid, subulate, shortly acuminate.-In the mountains of Nevada, 1871.

Hosackia * puberula, Benth. (Pl. Hartw. 305).-Perennial, herbaceous, usually a span high or more, canescently puberulent, slender : leaflets 3 to 5 upon a short rhachis, linear-oblanceolate, 6 to 9 lines long; stipules gland-like: peduncles exceeding the leaves, 1-5-flowered, with or without a sessile 1-5-foliolate bract: flowers half an inch long, yellow : calyx-teeth about equalling the tube: pod nearly straight, an inch long, pubescent, many-seeded.-New Mexico to Arizona; Rancheria Springs, Loew (119), and Sanoita Valley, Arizona, Rothrock (659).-H. rigida, Benth., is a form with the rhachis of the leaves very short or wanting, and the leaflets usually somewhat broader.

Hosackia Wrightir, Gray (Pl. Wright. ii, 42).-Like the last, but the peduncles wanting, the flowers being solitary in the axils upon a short pedi-

"Hosackis, Dongl.-Calyx-teeth nearly equal. Petals free from the stamens, nearly equal; standard often remote from the rest, ovate or roundish; keel curved, obtuse or somewhat acutely beaked, Stamens diadelphous; anthers nniform. Pod linear, compressed or nearly terete, sessile, several-seeded, with partitions between the seeds.-Herbaceons or rarely woody, with pinnate 2-nans-foliolate leaves; stipules mostly minute and glandlike; flowers in axillary sessile or pedunculate umbels, jellow, often lecoming brownish. 
cel, or rarcly shortly pedunculate: leaflets mostly linear, palmate upon a very short petiole or sessile.-New Mexico and Arizona; Willow Syrings, Ioew (1114), and White Mountains, Arizona, Loew (113), and Fort Wingate, N. Mex., Rothrock (152).

Hosackia Purshiana, Benth.-Annual, usually a foot high or more, and more or less silky-villous: leaflets 1 to 5 , ovate to narrowly lanceolate, 2 to 9 lines long; stipules gland-like: flowers small, yellow, on peduncles exceeding the leaves, bracteate with a single leaflet: calyx-teeth linear, much exceeding the tube, about equalling the corolla: pod linear, straight, smootil, an inch long, 5-7-seeded.-Frequent from the Mississippi to the Pacific; Nevada, 1871, and Camp Grant, Ariz. (368).

Tephrosia leiocarpa, Gray (Pl. Wright. ii, 36).-Perennial, erect, rather stout, a foot high or more, with a fine, appressed, silky pubescence: leaflets 6 to 10 pairs, linear-oblong, obtuse, mucronate, smooth above, shortly petiolulate, about an inch long: peduncles terminal and axillary, scarcely exceeding the leaves, rather few-flowered: calyx-lobes subulate, as long as the tube; petals large, purple, 9 lines long: pods linear, straight, glabrous, two inches long by three lines wide, sessile, about 10-seeded.Arizona, Sanoita Valley, Rothrock (685), near the original locality, where only it had been collected by Mr. Wright--Very near T. onobrychoides, Nutt. Differing in its short peduncles and smooth pods.

Tephrosia leucantha, H. B. K. (Nov. Gen. vi, 460, t. 577).-Perennial, erect or ascending, rather stout, about a foot high, appressed-pubescent and somewhat rusty silky-villous throughout, the hairs upon the petioles spreading: leaflets 5 to 12 pairs, oblong, rounded at each end, mucronate, an inch long: raceme terminal, short and shortly peduncled : flowers yellow, 6 or 7 lines long, exceeding the erect slender pedicels: calyx very villous, the slender lower teeth longer than the tube: style pubescent: pods narrowly linear, straight, spreading, densely rusty pubescent with short spreading latirs.-Southem Arizona, apparently identical with the typical form of Central Mexico; in Sanoita Valley, Rothrock (625).

Tephrosia tenella, Gray (Pl. Wright. ii, 36) - Annual, erect, very slender, a span high or less, nearly glabrous: leaflets 1 to 3 pairs, thin, linear, obtuse, mucronate, an inch long: flowers few, in an interrupted 
long-pedunculate raceme, purple, 3 lines long, on short pedicels, the lowest often subtended by a leaf: calyx-teeth subulate, equalling the tube: pods spreading, linear, straight, puberulent, an inch long, 4-6-seeded.-Southern Arizona, in Sanoita Valley, Rothrock (632 in part).

Indigofera* LeptostPala, Nutt. (Torr \& Gray, Fl. i, 298).-Annual, canescently pubescent, usually decumbent; stems a foot or two long: leaflets 3 or 4 pairs, cuneate-oblong, obtuse, a half to an inch long, sometimes smoother above: flowers nearly sessile, scattered in long-pedunculate racemes exceeding the leaves : petals pale scarlet, 4 or 5 lines long, nearly twice longer than the slender calyx-teeth: pods linear, terete, straight, pubescent, reflexed, an inch long or more, 6-9-seeded.-From Arizona and New Mexico eastward to the Atlantic; in Arizona, 1871 or 1872 , locality not given.

Astragalus caryocarpus, Ker.-From the Saskatchewan to Texas; at Denver, Wolf (232).

Astragalus lentiginosus, Dougl. (Hook. Fl. i, 151), and var. FreMoNTI, Watson, more hoary-pubescent; stem flexuous.-From Washington Territory through the interior to Southern Nevada; both forms were collected in Nevada, 1871.

Astragalus diphysus, Gray (Pl. Fendl. 34).-Scarcely more than a glabrous form of the last, with rather larger flowers; the pods usually larger and with somewhat thicker walls.-Northern Nevada to New Mexico; in Nevada, 1871, and New Mexico, Rothrock (183).

Astragalus Canadessis, Linn.-From Winnipeg Valley to Washington Territory, Northern Utah, and the Atlantic; in the Wahsatch, 1871.

Astragialus adsurgers, Pall. (Astrag. 40, t. 31).-From Winnipeg Valley to Nebraska and Colorado; South Park, Wolf (336).

Astragalus hypoglottis, Linn.-New Mexico to the Aretic Circle and Alaska; at Apex and South Park, Colorado, Wolf (231, 242, 867).

Astragalus Drummondi, Dougl. (Hook. Fl. i, 153, t. 57).-Perennial,

* Indigofera, Linn.-Calyx broad and ehort, oblique; teeth nearly cqual. Stavdard ovate or orbienlar; keel subulately spurred on each side. Stamens diadelphous; anthers uniform, glandnlar-8 pieulate. Style glabrons : stigma capitate. Pod globose to linear, 2-celled, 1-many-secded, with partiti: as between the truncats seeds.-Herbaceous or shrublyy, more or less pubescent with appressed buirs attached by the middle; leaves mostly uneqnally pinnate, with setaceous stipules; flowers iu axillaxy racenes or spikes, usually rose-colored or purple. 
villous throughout with spreading hairs, very stout, a foot or two high: leaflets 10 to 15 pairs, cuneate-oblong to linear, 6 to 9 lines long, often retuse: flowers in long and long-peduncled racemes, ochroleucous, about nine lines long, on rather slender pedicels: pods coriaceous, linear and exsertly stipitate, an inch long, terete or somewhat compressed, with a deep narrow dorsal furrow, and 2-celled or nearly so, smooth, nearly straight, reflexed.-From the Saskatchewan to Nebraska and Colorado; at Apex, Colo., Wolf (215).

Astragalus racemosus, Pursh (Fl. ii, 740).-Resembling the last, but glabrous or somewhat appressed-pubescent: pedicels slender: pod somewhat broader and more compressed.-From Nebraska to Southern Colorado and Idaho; at Apex (216) and South Park, Colo., Wolf (227, 251).

Astragalus humistratue, Gray (Pl. Wright. ii, 43).-Perennial, somewhat villous-pubescent with mostly appressed hairs: stems slender, procumbent, a foot long or more: leaflets 5 to 10 pairs, linear-oblong, acute, half an inch long: flowers nearly sessile in a loose long-peduncled raceme, spreading, 4 lines long, purplish: calyx-teeth equalling or exceeding the campanulate tube: pods coriaceous, sessile, pubescent, linear-oblong, half an inch long, curved, somewhat compressed contrary to the sutures, nearly 2-celled, with a deep dorsal furrow, the ventral suture prominent.-New Mexico to Sonora; in Western New Mexico, Loew (203).

Astragalus gracilis, Nutt. (Gen. ii, 100).-Perennial, somewhat appressed-pubescent, slender, erect or ascending, a foot high or more : leaflets 3 to 5 pairs, narrowly linear, half an inch long or less: flowers very small, white or purplish, in an elongated open long-peduncled spike: calyxteeth very short: pods coriaceous, sessile, pubescent and rugose, 2 or 3 lines long, ovate-oblong and obcompressed, 1-celled, concave on the back, and the ventral suture prominent.-From Minnesota to Arkansas and the Rocky Mountains; at Kit Carson, Colo., Wolf (248).

Astragalus aboriginum, Richardson. (Phaca aboriginum, Hook. Fl.i, 143, t. 66.)-From Colorado and Northern Nevada to the Arctic Zone; South Park, Wolf (249).

Astragalus oroboides, Hornem., var. Americanus, Gray--Allied to the last; more nearly glabrous : leaflets obtuse or retuse: flowers on longer 
pedicels, in a loose elongated raceme, purple: calyx-teeth shorter than tho tube: pod very shortly stipitate, pubescent, reflexed, half an inch long or less, oblong-ovate, nearly terete or slightly compressed.-From Colorado to Wyoming and the Saskatchewan; South Park, Wolf (233).

Astragalus alpinus, Linn.-From Maine to Washington Territory and northward, and south in the Rocky Mountains to Colorado; South Park, Wolf (211, 229, 244, 245, 246).

Astragalus lotiflorus, Hook. (Fl. i, 152).-Perennial, hoary with appressed silky hairs, very low and diffuse: leaflets 2 to 5 pairs, oblong to linear, a half to an inch long: flowers few, yellow, small, nearly sessile in a long-pedunculate or sessile spike: calyx-teeth at least as long as the tube, and often nearly equalling the petals : pods coriaceous, about an inch long, sessile, straight, pubescent, acuminate-oblong, obcompressed, 1-celled, with a more or less deep dorsal furrow, and the ventral suture somewhat prominent.-From Texas to Nebraska and northward; at Denver, Wolf (239).

Astragalus Missouriensis, Nutt. (Gen. ii, 99).-Perennial, canescent with closely appressed dense silky straight pubescence, low and shortly caulescent or nearly stemless: leaflets 4 to 9 pairs, oblong to rarely obovate, 2 to 4 lines long, acute or obtuse: spikes short, on peduncles equalling the leaves: flowers purple, rather large: calyx-teeth much shorter than the cylindrical appressed-silky tube: pods 8 to 12 lines long, thick-coriaceous, oblong and somewhat obcompressed, nearly straight, obtuse at base, pubescent and rugose, 1-celled, with the ventral suture prominent, and often more or less concave on the back.-A rather common species, from the Saskatchewan and Wyoming Territory to New Mexico; at Kit Carson, Colo., Wolf (240), and at Deer Spring, Ariz. (186).

Astragalus Shortianus, Nutt. (Torr. \& Gray, Fl. i, 331). (A. cyaneus, Gray, Pl. Fendl 34.)-Like the preceding, but the leaves broader and usually obovate; the pubescence upon the calyx of coarse, somewhat entangled hairs, not appressed; the pod as in the last, but larger, longer (sometimes two inches long), and more curved-Colorado to Wyoming and New Mexico; Clear Creek, Colo., Wolf (241), and N. Mexico, Rothrock (1112). 
Astragalus Parry, Gray (Am. Journ. Sei 2d ser. xxxiii, 410).-Similar in habit, but villous throughout with loose spreading hairs; stéms decumbent: leaflets obovate to oblong, often retuse and usually small: calyx-teeth large and about equalling the tube: pods narrower, an inch long and curved, more compressed, and nearly 2 -celled by the depression of the sutures-Colorado to Northwestern Texas; Wolf (237), but the locality not given.

Astragalus iodanthus, Watson (Bot. King's Expl. 70).-Northern Nevada and Utah. Flowering specimens collected in Cañon de Chelli (212) (also by Dr. Coulter, on Hayden's Survey, in Clear Creek Cañon) are perhaps referable to this species, though the corolla is nearly white.

Astragalus Utahensis, Torr. \& Gray (Pacif. R. Rep. ii, 120).-Utah to Nevada; near Salt Lake, 1872.

Astragalus lonchocarpus, Torr. (Pacif. R. Rep. iv, 80,-Perennial, erect, slender, puberulent or glabrate, a foot high or more: leaflets 4 pairs or fewer, often only a terminal inarticulated one, linear, about an inch long: flowers ochroleucous, 6 to 8 lires long, spreading in a loose longpedunculate raceme : calyx-teeth short : pods membranous, linear, attenuate at each end and long-stipitate, an inch and a half long, straight, glabrous, reflexed, terete or obcompressed, 1-celled, the sutures usually somewhat impressed.-Colorado to New Mexico and Utah; Santa Fé (1૪).

Astragalus pectinatus, Dougl. (Hook. Fl. i, 14?).-Perennial, puberulent or glabrate, erect and stout, a foot high or more: leaflets 5 to 8 pairs, not jointed upon the rhachis, narrowly linear, an inch or two long: flowers large, spreading in a loose pedunculate raceme, ochroleucous: pods thick-cartilaginous, somewhat pubescent, ovate or oblong, turgid, sessile, half an inch long, reflexed, 1-celled, with thick prominent sutures.-From the Saskatchewan to Colorado and Oregon; at Kit Carson, Colo., Wolf (234).

Astragalus Fenderi, Gray (Pl. Wright. ii, 44).-Perennial, puberulent, slender, erect or decumbent, a foot high or more: leaflets 7 to 12 pairs, oblong to linear, obtuse, about half an inch long: flowers purple, 4 or 5 lines long, spreading in loose long-pedunculate racemes: calyx-tube and teeth short: pods coriaceous, slightly pubescent or glabrate, broadly 
linear, nearly an inch long, sessile or very nearly so, reflexed, usually somewhat-compressed, 1-celled, with neither suture very prominent or impressed.-Colorado and New Mexico ; at Apex, Wolf (226).

Astragalus HalliI, Gray (Proc. Am. Acad. vi, 224).-Distinguished from the last chiefly by the pods, which are glabrous, shortly stipitate, oblong, 9 lines long: flowers a little larger, violet, in short and denser racemes: leaflets often retuse.-Colorado to New Mexico; South Park, Wolf $(228,247)$.

Astragalus cyrtoides, Gray (Proc. Am. Acad. vi, 201).-Northern Nevada, where it was collected in 1871.

Astragalus moltiflorus, Gray (Proc. Am. Acad. vi, 226).-In the mountains from New Mexico and Nevada to the Saskatchewan and Washington Territory; at Santa Fé, Rothrock (40), in the South Park, Wolf (207, 250), and in Nevada, 1871.

Astragalus tegetarius, Watson (Bot. King's Expl. 76, t. 13).-Colorado and Northern Nevada; South Park, Wolf (243).

Astragalus campestris, Gray (l. c. 229).-Wyoming to Utah and New Mexico; on the Blue River, Colorado, Wolf $(218,230)$.

Astragalus junceus, Gray (l. c. 230).-Wyoming to Southern Utah and Colorado; Denver, Wolf (235).

Oxytropis Lamberti, Pursh-From the Saskatchewan to Texas and Arizona; at Oro City and Kit Carson, Colo., Wolf (220-224), and at Chiricahua Ageney, Ariz. (528).

Oxytropis splendens, Dougl. (Hook. Fl. i, 127).--Similar to the last: pubescence more villous and spreading: leaflets many pairs, somewhat verticillate: spikes dense and very villous, the smaller flowers ( 1 to 6 lines long) scarcely exceeding the bracts : pods ovate, half an inch long.-From Northern New Mexico to British America; South Park, Wolf (225).

Oxytropis CaMPESTRis, Linn., var. viscida, Watson (Bot. King's Expl. 77). (O. viscida, Nutt.)-More or less viscid with resinous dots.-Wyoming to Northern Nevada and Colorado; South Park, Wolf (252).

Oxytropis multiceps, Nutt. (Torr. \& Gray, Fl. i, .341).-Alpine, dwarf, acaulescent, an inch or two high, canescently appressed-silky, the hairs spreading upon the peduncles and inflorescence: leaflets 2 or 3 pairs, 7 BOT 
linear-oblong, 1 to 3 lines long, acute: peduncles as long as the leaves, about 2-flowered: calyx becoming inflated and globose in fruit; teeth not equalling the tulse: corolla purple, half an inch long: pods included in the calyx, ovate, partially 2 -celled by the intrusion of the ventral suture, shortly stipitate, very pubescent.-Colorado; at Gold Hill, Wolf (213).

Oxytropis deflexa, DC. (Prodr. ii, 280).-Caulescent, erect, often a foot high or more, silky-villous: leaflets 10 to 15 pairs, oblong-ovate or lanceolate, acute, half an inch long: flowers small, purple, in at length elongated spikes on very long peduncles: calyx-teeth as long as the tube and equalling the corolla : pod coriaceous, linear-oblong, 6-8 lines long, reflexed, pubescent, partially 2-celled by the intruded ventral suture.-In the Rocky Mountains from the Saskatchewan to New Mexico; South Park, Wolf (217).

Glycyrrhiza lepidota, Nutt.-From Washington Territory to Hudson Bay and southward to Nevada, New Mexico, and Arkansas; at Covero, N. Mex., Rothrock (106), in the valley of the Upper Arkansas, Colorado, Wolf (190), also in Nevada and Utah, 1871 and 1872.

Psoralea lanceolata, Pursh (Flora, 475).-Frequent from Washington Territory to Northern Arizona, and eastward to Nebraska; at Denver, Wolf (181).

Psoralea floribunda, Nutt. (Torr. \& Gray, Fl. i, 300).-Resembling the last, more or less canescent, with short white appressed hairs: petioles mostly very short: peduncles exceeding the leaves, and flowers on short slender pedicels: calyx-teeth acute-From Texas to Western Arizona; Neutria, N. Mex., Rothrock (145), and in Eastern Arizona, Loew (858).

PARRYElLA* FILIFolia, Torr. \& Gray.-Puberulent or nearly glabrous, diffusely branched, apparently a foot high or more: leaves 2 or 3 inches long; leaflets 10 to 15 pairs, linear-revolute, 3 or 4 lines long, with acute glandular stipules: spikes slender; bracts very small, acute: calyx nearly

*Parryelis, Torr. \& Gray, Proc. Am. Acad. vii, 397.-Calyx obconical, persistent; teeth short, nearly equal. Petals wanting. Stamens 10 , distinct, inserted on the base of the calyx; anthers unifurm. Orary 2-ovuled. Pod indebiscent, obliquoly obovate, exserted, 1-8eeded, glaudular-dotted.-A low ehrub, with numerons slender branches, sparingly glandular-punctate; leaves unequally pinnate, with glandular s'ipules; leaflets numerous, linear, stipellate; flowers spicate on terinisal peduncles. 
sessile, a line and a half long: filaments and pubescent style slightly exserted: pod 3 or 4 lines long, attenuate at base--New Mexico and Arizona, rarely collected; near Santa Fé, Rothrock (91). Plate II.*

Aмorpha Fruticosa, Linn.-In its various forms from Winnipeg Valley to Texas and New Mexico and eastward to the Atlantic; at Willow Spring, Ariz., at 7,200 feet altitude, Rothrock (244), apparently the typical broadleaved form, in flower, and resembling specimens collected at San Diego, Cal., by Palmer (65), in 1875. Only the fruit will determine positively whether it be not $A$. Californica, Nutt., which has a shorter and broader pod than the Eastern species, and usually more slender and acute calyx-teeth.

Petalostemon candidus, Michx.-From the Saskatchewan to Arizona and eastward to Michigan and the Mississippi ; at Willow Spring, Ariz., Rothrock (248), and Cosino Caves, Loew (192).

Petalostemon tenuifolius, Gray (Proc. Am. Acad. xi, 73).-Perennial, branching, pubescent or glabrate, low : leaflets 3 to 5 , linear or revolute-filiform, 3 to 6 lines long, about equalling the petiole, sparingly glandular: spikes ovate to cylindrical, dense, rather long-pedunculate; bracts ovate, rather abruptly attenuate into a long awn, densely silky-villous as well as the calyx: calyx-teeth lanceolate, attenuate, equalling the tube: petals rose-colored; standard round-cordate, hooded.-Western Arkansas to New Mexico; Arizona, Rothrock (81) Plate II. $\dagger$

Dalea alopecuroides, Willd-From Sonora to Colorado and eastward to Texas and Southern Illinois; Arizona or New Mexico, Loew (274).

Dalea albiflora, Gray (PI. Wright. ii, 38).-Perennial, herbaceous, erect, more or less hoary-pubescent, a foot high or more: leaflets small, 10 to 15 pairs, narrowly oblong, obtuse, smoother above, 2 or 3 lines long: spikes cylindrical, dense and densely white-silky; bracts subulate-setaceous, exceeding the calyx: teeth of the calyx subulate, a little shorter than the tube: petals white.-New Mexico to Sonora; Camp Bowie, Ariz. (502).

*A. Branch; natural size. Fig. 1. Flower. Fig. 2. A vertical section throngh flower. Fig. 3. Stamineal tube laid open. Fig. 4. Matare legume. Fig. 5. A vertical section through the same, showing the seed and embryo. All except the branch enlarged about five diameters.

+B. A branch somewhat reduced. Fig. 6. A bract from beneath the flower. Fig. 7. A flower seen from the side. Fig. 8. A flower seen from above, with four petals on the stamineal column, and the fifth on the calyx. Fig. 9. A section through the pod, with the seed in position. All except the branch enlarged about five diameters. 
Dalea Jamesir, Torr. \& Gray (Fl. i, 308).-Densely appressed-silky, the somewhat decumbent stems 2 to 4 inches high from a branching woody base: leaflets 3, oblanceolate or oblong, half an inch long, equalling the petioles: spikes sessile, ovate to oblong, rather dense, very villous with long silky hairs; bracts lanceolate, acuminate, about equalling the long plumose calyx-teeth, which much exceed the tube: petals yellowish or rosecolored, 5 lines long, scarcely exceeding the calyx.-New Mexico; western part of the Territory, Loew (189), locality not given.

Dalea Wislizent, Gray (Pl. Fendl. 32).--Shrubby, with slender virgate branches, pubescent, a foot high or more: leaflets 7 to 9 pairs, oblong, obtuse, smoother above, 2 lines long or less: spikes short-ovate or oblong, dense, long-pedunculate, silky-villous; bracts lanceolate, long-acuminate, equalling the calyx : teeth of the calyx setaceous, plumose, a little longer than the tube, with a narrow tooth on each side: petals rose-colored, 4 or 5 lines long, twice longer than the calyx, with solitary glands near the top.New Mexico to Sonora; Southern Arizona, Rothrock (594).

Dalea formosa, Torrey (Emory's Rept. 138, t. 1).-A low shrub, 1 to 3 feet high, with spreading flexuous branches, glabrous or nearly so: leaflets 3 to 5 pairs, cuneate-oblong, rarely 2 lines long, often very small and revolute: flowers few and spreading, in short spikes; bracts caducous: calyx very silky-villous, the setaceous plumose teeth longer than the tube and nearly equalling the corolla: petals deep rose-color, very unequal, the keel half an inch long.-New Mexico and Arizona; Camp Bowie, Rothrock (450).

Dalea Fremontr, Torrey (Gray, Pl. Thurb. 316).-In Southern Nevada, 1871 ; it has also been found in Southern Utal.

Heuysarum Mackenzir, Richardson (Torr. \& Gray, Fl. i, 357).-In the Rocky Mountains of British America and southward to Wyoming and Utah; in the Wahsatch, 1871.

Zornia* Diphylla, Persoon. (Z. reticulata, Smith.)-Slender, erect or

"Zorsu, Gmelin.-Calyx membranaceous, the two upper lobes connate, the lateral ones much smaller. Standard orbicular. Stamens united into a closed tube; alternate anthers shorter and versatile. Stylo filiform. Stigna terminal. Pod compressed, 2-5-jointed, the indehiscent joints rouvded, nsually hispid.-Herbs, mostly annnal, with palmately 2 -4-foliolate leaves, and foliaceons stipules; flowers yellow, solitars, sessilo between a pair of large foliaceous stipular bracts, forming an interrupted spike.Bкмтн. \& Hook., Gen. Pl. i, 518. 
decumbent, a span high, puberulent and somewhat villous or glabrous: leaflets 2, ovate to linear, a half to an inch long, mostly acute and ciliate; stipules narrow, auricled downward at base and peltately attached, as also the floral bracts, which are closely appressed; ovate to lanceolate, 4 to 6 lines long, and nearly including the flower: pod small, included in the bracts or a little exserted.-A variable species, ranging from Arizona and New Mexico to Brazil, and also in the East and West Indies; Sanoita Valley, Ariz., Rothrock (620).

Desmodium cinerascens, Gray (Pl. Wright. ii, 48).-Perennial, decumbent or procumbent, cinereous with soft appressed hairs, the rather stout straight stems 2 to 4 feet long: leaflets elliptic-oblong, obtuse at each end, an inch or two long, exceeding the petiole, conspicuously marked beneath by the white-silky veins: racemes paniculate, many-flowered: flowers purple, 3 or 4 lines long, on shorter pedicels: pods 5-7-jointed, nearly equally constricted on both edges, puberulent; joints 2 or 3 lines long.-Arizona to Northern Mexico; Sanoita Valley, Ariz., Rothrock (660).

Desmodium Neo-Mexicanum, Gray (Pl. Wright. i, 53). (D. exigum, Gray, l. c. ii, 46.)-Annual, very slender, erect, a foot or two high or more, sometimes procumbent, pubescent with very short spreading and somewhat glandular hairs, paniculately branched: leaflets 3, linear (or the lowermost ovate and shorter), an inch or two long or more, thin and reticulated, the narrow petioles an inch long or less: flowers minute (about a line long), on very slender, elongated pedicels, purple: pods 1-5-jointed, puberulent; joints rounded, reticulated, a line and a half long, the margins often undulate-Var. Bigelovir (D. Bigelovii, Gray, l. c. ii, 47). Leaves somewhat broader near the base.-From New Mexico to Arizona and Northern Mexico; in Central Arizona, Loew, 1873, also in Sanoita Valley, Rothrock $(632,663)$, the latter number referable to the variety.

Desmodium вatocaulon, Gray (Pl. Wright. ii, 47).- Stem elongated, procumbent, pubescent and adhesive by hooked hairs: leaflets 3 , oblonglanceolate, 1 to $2 \frac{1}{2}$ inches long, obtuse or acutish, rounded at base, somewhat pubescent with straight hairs, which are spreading upon the petiole: flowers purple, in loose elongated racemes, 3 to 6 lines long, on slender pedicels nearly as long; bracts broadly ovate, acuminate, 2 lines long, 
caducous: pods shortly stipitate, 5-7-jointed; joints triangular-rounded, nearly smooth and glabrous, $1 \frac{1}{2}$ to $2 \frac{1}{2}$ lines long.-Southeastern Arizona, previously collected only by Mr. Wright in the valley of the San Pedro; at Rocky Cañon, Camp Grant, and Chiricahua Agency, Rothrock (290, $366,531)$. It seems to differ only in its smoother pods from $D$. Sonorce, Gray, $l$. $c$., which is referred by Bentham to D. uncinatum, DC., of Mexico and southward. The latter has usually much larger, conspicuous bracts, broader leaves, and more densely tenacious-pubescent pods.

Vicia Americana, Muhl., var. linearis, Watson (Proc. Am. Acad. xi, 134). (Lathyrus linearis, Nutt.) - Leaflets linear.-A very common western form; San Francisco Mountains, 1872, and at Willow Spring, Ariz., Rothrock (224 in part), also at Denver, Colo., Wolf (185). Specimens of nearly the typical form were collected near Denver, Wolf (186), and in Nevada and Utah, 1871 and 1872.

Vicia pulchella, H. B. K. (Nov. Gen. vi, 499, t. 583).-Tall and very slender, sparingly silky-pubescent: leaflets linear, obtuse or acute, mucronate, a half to an inch long; stipules narrow : flowers small, numerous, usually crowded in long-peduncled racemes, equalling the leaves, pale purple or ochroleucous, 2 or 3 lines long, reflexed: pods linear-oblong, an inch long, nearly sessile, puberulent, 6-8-seeded.-From Western Texas to Arizona and southward; Mount Graham, and Willow Spring, Ariz., Rothrock $(211,434,1006,1004)$.

Lathyrus Paluster, Linn.-The prevalent form has the leaves very narrowly linear:-Collected in Utah in 1872, at Clear Creek, Colo., Wolf (187), at Big Dry Fork, Ariz., Loew (204), at Rocky Cañon and Willow Spring, Ariz., Rothrock $(286,224$ in part), and also at Fort Wingate, N. Mex., Rothrock (142).-The broader-leaved var. Myrtifolius, Gray, appears to have been collected in the Wahsatch in 1872 , referred in the published list to $L$. venosus.

Lathyrus polymorphus, Nutt. (Gen. ii, 96).--Perennial, erect, a foot or two bigh, stout and scarcely climbing, finely pubescent or glabrous, glaucous : leaflets 3 to 6 pairs, thick and strongly nerved, narrowly oblong, acute at each end, an inch or two long; stipules narrow, acuminate: peduncles equalling the leaves, 2-6-flowered: flowers purple, very large, 9 
to 15 lines long: pod 2 inches long, upon a stipe as long as the calyx, 3 or 4 lines broad: seed with a very narrow funiculus and short hilum.-From Northern Colorado to New Mexico and Central Arizona; at Santa Fé, Rothrock (3, 9), and in Arizona, 1872.

Cologania* longifolia, Gray (Pl. Wright. ii, 35).-Perennial, climbing, 2 or 3 feet high, pubescent throughout with short appressed hairs or nearly glabrous: leaflets 3 , rarely 4 or 5 , linear to linear-oblong, 1 to 4 inches long, about equalling the petiole, obtuse, mucronate, reticulated beneath, glabrous above: flowers solitary in the axils, on short pedicels, purple, 9 lines long, twice longer than the calyx : pods straight, narrowly linear, an inch and a half long, pubescent, 10-14-seeded--New Mexico and Arizona; on the Mogollon Mesa, Loew (205), and at Willow Spring, Ariz., Rothrock (214).

Galactia tephrodes, Gray (P1. Wright. ii, 34).-Perennial, low and erect or twining, 2 or 3 feet high, canescent with soft appressed pubescence : leaflets 3, oblong to linear-oblong, obtuse at each end, mucronate, an inch long, smoother above, exceeding the petioles: flowers scattered in usually elongated racemes, half an inch long, twice longer than the calyx : pods somewhat curved, linear, nearly two inches long, appressed-pubescent.New Mexico and Arizona; near Camp Bowie, Rothrock (487).

Phaseolus Wrighti, Gray (Pl. Wright. i, 43).-Stems prostrate or twining, slender, from a perennial woody fusiform root; sparingly roughpubescent: leaflets 1 or 2 inches in diameter, hastately lobed, the lateral lobes quadrangular, often repand at the end, the terminal one oblong, obtuse or acute, mucronate: peduncles exceeding the leaves, few-flowered: flowers purple, 3 to 8 lines long, exceeding the pedicels : pods an inch long, reflexed, compressed, falcate, pubescent, 6-8-seeded--New Mexico and Arizona; on Mount Graham, at 9,250 feet altitude, and at Chiricahua Agency, Rothrock $(417,535)$, and in woods on Mogoilon Mesa, Loew (206).

*Cologania, Kunth.-Calyx tubular; upper teeth connate, the lower one longest. Standard obovate, with broad claw and reflexed sides; keel sborter, slightly incurved. Stamens diadelphous; antherś uniform. Style naked : stigma capitate. Pod linear, straight, compressed, stipitate, 2-valved, somewhat partitioned between the sereral seeds.-Twining herbs, with 3- (rarely 1-5-) foliolate leaves, ruther large axillary purple or rose-colored flowers, and persistent narrow bracts and bractlets,-BENrF. \& Hook. Gen. Pl. i, 529. 
Phaseolus Retusus, Benth. (Pl. Hartw. 11).-Stems stout, trailing, 6 to 8 feet long, from a very large perennial root, pubescent with short spreading hairs: leaflets rhomboid-ovate, 2 or 3 inches long, thick, obtuse or acutish, occasionally retuse, mucronate, strongly reined : racemes elongated and long-pedunculate, rather many-flowered: flowers purple, half an inch long, on short pedicels : pods broadly oblong, slightly falcate, 2 inches long, compressed, 4-6-seeded.-From Western Texas to Arizona; at Chiricahua Agency, Ariz., Rothrock (522).

Rhynchosia Texana, Torr. \& Gray (Fl. i, 687).-Diffuse, slender, somewhat twining, a foot or two high, minutely pubescent throughout: leaflets ovate to linear-oblong, an inch long or usually less, obtuse at each end, mucronulate, often resinous-dotted beneath: flowers 3 lines long, on short pedicels, solitary in the axis, or rarely 2 to 5 together upon a very short peduncle: pods oblong, narrowed to the base, about 8 lines long.From Texas to Arizona; at Sulphur Springs, Ariz., Rothrock (545).

Hofrmanseggis* Jamesir, Torr. \& Gray (Fl. i, 393),_Finely pubescent; stems clustered, herbaceous, from a stout woody root, erect or decumbent, often a foot high or more: pinnæ 1 to 3 pairs; leaflets 4 to 7 pairs, oblong, obtuse, 2 or 3 lines long, glandular-dotted beneath: stipules and bracts subulate-setaceous : raceme open: sepals oblong, acute, 3 or 4 lines long, equalling the corolla, glandular-dotted, as also the upper petals : claws of the petals short and nearly naked: pods an inch long, nearly half as broad, falcate, dotted and pubescent, with plumose hairs on the edges, 2-1seeded.-From Colorado and Texas to New Mexico; at El Rito and elsewhere in New Mexico, Rothrock (95, 1010).

Hoffmansegeia stricta, Benth. (Gray, Pl. Wright. i, 56).-Finely pubescent, somewhat glandular above, not glandular-dotted; the clustered stems erect, from a perennial root, a half to a foot high : pinnæ 4 to 6 pairs; leaflets 6 to 8 pairs, oblong, obtuse, a line or two long; stipules and bracts

" Horfanansegia, Cavanilles,-Calyx-tube very short, the 5 oblong or lanceolate, nearly equal segments slightly imbricate or valvate. Petals oblong or ovate, slightly unequal, imbricated, the upper one included and usually dissimilar. Stamens 10, distinct; flaments usually glabdular at base; anthers uniform, versatile, dehiscent longitudinally. Style often incurved-clavate; stigma terminal. Pod flat, thin, 2-valved, linear or ovate, several-seeded.-Perennial herbs or low sbrubs, mostly glabdular, with bipinnate leaves and small leaflets, yellow racemose flowers, and deciduous bracts_-Bexтн. \& Ноок. Gen. Pl. i, 567. 
broadly ovate: racemes open: sepals oblong, obtuse, more or less pubescent, 3 lines long, a half shorter than the corolla: upper petal veined with purple, the claws and outer filaments densely stipitate-glandular: pods linear-oblong, an inch long or more, nearly straight, puberulent and somewhat stipitate-glandular, 6-12-seeded.-From New Mexico and Arizona to Northern Mexico; at Camp Goodwin, Ariz., Rothrock (351).

HoffMansegGia DREPanocarpa, Gray (Pl. Wright. i, 58).-Puberulent, not glandular nor glandular-dotted, the stems scarcely 6 inches high. from a perennial root: pinnæ 2 to 5 pairs; leaflets 4 to 10 pairs, oblong, obtuse, 2 or 3 lines long; stipules and bracts broadly ovate: racemes open: sepals oblong, acute, 2 or 3 lines long, about equalling the obovate sessile naked petals: pods linear-oblong, curved, obtuse, an inch long or more, puberulent, 6-10-seeded.-Colorado to New Mexico and Arizona; at Camp Bowie, Ariz., Rothrock (1008).

Parkinsonia* microphylla, Torrey (Bot. Mex. Bound. 59).-A shrub 5 to 10 feet high, with smooth light-green bark, much branched, the straight rigid branchlets spinulose; the younger branches and inflorescence somewhat puberulent: common petioles very short or none, rarely spinescent: leaflets 4 to 6 pairs, on a terete rhachis, broadly oblong or rounded, obtuse or acutish, not narrowed at the oblique base, glaucous, 2 lines long or less: racemes very short, axillary and sessile; pedicels evidently jointed a little below the flower: calyx valvate: petals 3 or 4 lines long, deep strawcolor, the upper one white: anthers orange, exserted: ovary appressedsilky: pod 2 or 3 inches long, attenuate at each end, 1-3-seeded, contracted between the seeds.-Southern Arizona, from the Colorado eastward; collected in 1871 , the locality not given.

Cassia bauhinioides, Gray (PI. Lindh. ii, 180).-Perennial, herbaceous, a span high, stout, cinereous with a usually dense, more or less appressed pubescence: leaflets a single pair, oblique, ovate-oblong, obtuse, 8 to 15

- Parionsonia, Linn.-Calyx 5-parted, with a lung-turbinate base jointed on the pedicel; divisions mostly valvate. Petals with claws, the upper included and broadest, somewhat cordate; the claw pubescent and nectariferous. Stamens 10, distinct; filaments pilose at base, the upper one gibbous; anthers versatile, dehiscent longitudinally. Style filiform, acute. Pod thin-coriaceous, 2-valved, linear to linear-oblong, compressed, usually more or less torulose. Seeds albuminous.-Trees or slorubs, often spinose; leaves bipinnate, the common petiole short (often næ; flowers jellow, on slender pedicels, in short loose racemes.-Watson, Flora Calif. i, 162. 
lines long; a gland between the leaflets: stipules and bracts setaceous: peduncles axillary, 1-2-flowered, a little exceeding the petioles: sepals oblong-ovate: petals veined, 4 to 6 lines long: stamens 7: pods hispid, an inch long or more, nearly straight, compressed, 2-valved, many-seeded.Western Texas to Arizona ; at Camp Bowie and Cottonwood, Ariz., Rothrock $(1007,360)$.

Cassia Covesir, Gray (Proc. Am. Acad. vii, 399).-Resembling the last, but more canescent, with 2 or 3 pairs of leaflets, and the 3-7-flowered pechumeles exceeding the leaves: pods appressed-pubescent.-From Arizona to Lower California; collected in Northern Arizona in 1871, locality not given.

Cassia armata, Watson (Proc. Am. Acad. xi, 136).-Perennial, herbaceous, 3 feet high, minutely puberulent, light green: leaflets 2 or 3 pairs, distant, upon an elongated rigid flattened spinulose rhachis, thick, roundovate, a line or two in diameter, acutish, the margin revolute; stipules and glands wanting: flowers yellow, 2 or 3 lines long, in a short terminal raceme: stamens 7 : ovary slightly pubescent; pod glabrate, shortly stipitate, linear, compressed, somewhat curved, many-seeded.-Known only from imperfect specimens collected in Western Arizona in 1871, and also previously by Dr. Cooper in the California Desert.

Cassia Wrightir, Gray (Pl. Wright. ii, 50).-Perennial, woody at base, with numerous slender ascending stems, glabrous, a foot high: leaflets 4 to 6 pairs, narrowly oblong, obtuse, 2 or 3 lines long, thin, the midvein nearer the upper edge; stipules subulate, nerved; a stipitate gland below the lowest leaflets: pedicels solitary, axillary, exceeding the leaves, spreading: sepals membranaceous, unequal, 4 or 5 lines long: petals clear yellow, a half longer: pods linear, flat, shortly stipitate, an inch long or more, 6-8-seeded.-New Mexico and Arizona; at Camp Crittenden, Rothrock (683).

Cassia nietitans, Linn.-From Arizona to the Atlantic and southward; in Sanoita Valley, Rothrock (629).

Prosopis juliflora, DC. (Benth. Rev. Mim. 377). (P. glandubosa, Torr )_Shrub or tree, becoming 30 or 40 feet high, glabrous or puberulent, often with stout axillary spines: leaflets 6 to 30 pairs, oblong to linear, 
half an inch long or often more: spikes cylindrical, usually dense, shortly pedunculate, 2 to 4 inches long, 1-3-fruited: flowers a line long: pods 4 to 6 inches long or more, stipitate, straight or curved, sarrow, flat, at length thickened and pulpy within.-From Texas to Southern California and southward to Chili and Brazil ; at Ash Meadows, Southern Nevada, in 1871, and in the Gila Valley, Rothrock (320).

Prosopis pubescens, Benth. (Lond. Journ. Bot. v, 82). (Strombocarpus pubescens, Gray.)-New Mexico to Southern California; at Ash Mcadows, Southern Nevada, 1872.

Desmanthus Jamesir, Torr. \& Gray (Fl. i, 402).-Slightly puberulent, erect or decumbent, a foot high or less: pinnæ 3 to 6 pairs, the lowest approximate to the stem; leaflets 8 to 13 pairs, oblong, acutish, not veined, 2 lines long or less; gland large, oblong; stipules very small: heads large, 3 or 4 lines in diameter without the stamens, on peduncles an inch in length or often much less: pods linear, straight or nearly so, 3 or 4 inches long, obtuse or acute, 12-16-seeded-Var. (?) Fendleri, with smaller fewer-flowered heads, and the thick pods 2 inches long or more, and usually 8-1\%-seeded.-From Arkansas and New Mexico westward; at Cooley's Ranch and Camp Apache, Ariz., Loew (1116) and Rothrock (255), and the variety at Rocky Cañon, Ariz., Rothrock (291), and Cañon del Diablo (192); the last referred doubtfully in the catalogue to $D$. velutinus. This variety is identical with 179 Fendler and । 69 Wright, considered by Dr. Gray (PI. Wright. i, 63) to be a form of D. Jamesii, but placed rather under $D$. reticulatus by Bentham (Rev. Mim.). The earlier reference appears to be the better.

Mrmosa* Biuncifera, Benth (Pl. Hartw. 12).-A shrub 6 feet high, puberulent, with a pair of short stout recurved prickles below each leaf: pinnæ 4 to 7 pairs; leaflets 10 to 15 pairs, narrowly oblong, obtuse, a line long or less; stipules setaceous; occasionally very small prickles upon the

* Mrmosa, Linn.-Flowers perfect or poljgamous. Culyx mostly minute, rarely campanulate, shortly toothed. Petals connate, valvate. Stamens as many or twice as many as the petals, distinct, exserted; pollen-grains numerons. Style filiform. Pod oblong or linear, membranaceous or coriaceous, compressed, the 2 valves at length separating from the persistent margin.-Herbs or shrubs, often armed ; leaves bipinnate, the petioles without glands and the pinnæ stipellate; flowers small, sessile in globose or cylindrical spikes, on solitary or fascicled axillary peduncles, or the uppermost racemose.-BENTI. \& Hook. Gen. P1. i, 593. 
rhachis : peduncles solitary or in pairs, a little shorter than the leaves: flowers capitate, minutely pubescent, purplish : ealyx campanulate, half the length of the petals: stamens 8 or 10: pods sessile, linear, falcate or nearly annular, an inch long, flat, glabrous, continuous, the margins usually sinuous and. armed with a few short prickles or naked.-New Mexico to Arizona and southward; collected in Arizona in 1872, and at Rocky Cañon, Rothrock (272).

Mrmosa borealis, Gray (Pl. Fendl. 39).-An erect shrub, glabrous throughout, armed with scattered very stout recurved prickles: pinnæ 1 or 2 pairs; leaflets 3 to 5 pairs, oblong, 1 to $1 \frac{1}{2}$ lines long: peduncles solitary or in pairs, half an inch long or more, exceeding the leaves: flowers capitate, purplish: calyx very shortly campanulate: corolla deeply cleft: stamens 8 or 10: pods stipitate, an inch or two long, 3 or 4 lines broad, glaucous, continuous or at length separating into 3 or 4 joints, the sinuous margins armed with stout prickles.-From Western Texas to Arizona, where it was collected in 1872 , but locality not given.

Mimosa dysocarpa, Benth. (Gray, Pl. Wright. i, 62).-Diffusely branched and apparently procumbent, pubescent throughout, both the stem and petioles armed with numerous scattered flattened somewhat recurved prickles: pinnæ 6 to 10 pairs; leaflets 3 to 10 pairs, oblong, acutish, silky-pubescent both sides, $1 \frac{1}{2}$ to 2 lines long, the nerve near the margin: spikes axillary, solitary or in pairs, oblong and rather loosely flowered, shorter than the leaves and shortly pedunculate: calyx campanulate, half the length of the purplish deeply cleft corolla: stamens 8 or 10: pods stipitate, linear, flat, $1 \frac{1}{2}$ to 2 inches long, very densely pubescent, at length separating into 4 to 6 joints, the thick margin often armed.-From Western Texas to Arizona, and probably southward; at the Chiricahua Agency, Rothrock (511).

Acacia * GreggiI, Gray (Pl. Wright. i, 65).-A small tree 10 to 20 feet high, pubescent or glabrous, unarmed or with seattered stout recurved prickles: pinnæ 2 or 3 pairs, on a slender petiole; leaflets 4 or 5 pairs,

"Acacra, Willd.-Flowers perfect or polygamous. Calyx usually campanulate, and 4-5.toothed. Petuls more or less united. Stamens numerous, exserted, distinct or nearly so; anthers small : pollengrains united into 2 to 4 masses in each cell. Stylo filiform. Pod 2-valved or indehiscent, compressed and membrauaceons, or more or less thickened and terete, many-seeded. Seeds compressed.-Shrubs or tries, often spinose or prickly; leaves bipinnate, with small leaflets; stipules very small or spinescent; flowers swall, yellowish, in globose or cylindrical opikes on axillary peduncles. 
oblnng or oblong-obovate, 2 or 3 lines long, rounded or truncate above, narrower at base, rather thick and with 2 or 3 straight nerves: flowers in cylindrical spikes an inch or two long, the peduncles equalling or exceeding the leaves: pods thin-coriaceous, flat, 3 or 4 inches long by 5 to 7 lines broad, shortly stipitate, acute, curved, glabrous and reticulated, more or less constricted between the seeds: seeds half an inch long.-From Western Texas to Southern California; collected in Western Arizona, 1872.

Acacī constricta, Benth. (Gray, Pl. Wright. i, 66).-A shrub 5 to 8 feet high, puberulent or nearly glabrous, somewhat glutinous, more or less armed with nearly straight slender stipular spines, 3 or 4 lines long or less : pinnæ 2 to 7 pairs; leaflets 6 to 10 pairs, narrowly oblong, obtuse, 1 to $1 \frac{1}{2}$ lines long: peduncles solitary, shorter than the leaves, bracteate in the middle: head globose, 3 or 4 lines in diameter in flower : pods stipitate, narrowly linear, 2 to 4 inches long, curved, glabrous, flat, contracted between the distant seeds.-From Western Texas to Arizona and southward; collected at Cottonwood, Cienega, and in the Gila Valley, Ariz, Rothrock (322, 553).

Acacia rilicina, Willd. (A. hirta, Nutt. A. Texensis, Torr. \& Gray. A. cuspidata,-Schlecht. A. Hartwegi, Benth.; \&c.)-A shrub 1 to 5 feet high, erect, pilose-hirsute or glabrate, unarmed: pinnæ 4 to 20 pairs, a half to two inches long; leaflets 10 to 60 pairs, linear or linear-oblong, acute or obtusish, $1 \frac{1}{2}$ to 3 lines long: heads globose, rather few-flowered, on slender peduncles a half to an inch long, mostly paniculate: flowers pedicellate: ealyx very short: corolla greenish, a line long: stamens pale yellow, rarely pinkish: pods stipitate, 1 to 3 inches long, 3 to 5 lines broad, flat, straight, with thin valves and nerve-like margins, 3-8-seeded.-Arkansas to Arizona and southward to Central America; in Western Arizona, 1872, and at Rocky Cañon, Rothrock (300).

Calliandra* humilis, Benth. (Lond. Journ. Bot. v, 103). (C. herbacea, Engelm. in Gray, Pl. Fendl. 39.)-A span high or less, nearly herbaceous, ascending from an elongated woody root, pilose or sometimes

*Callundra, Benth.-Flowers yolygamous. Calyx campanulate, 5-6-toothed or cleft, valvate. Petals united to the niddle, valvate. Stamens usually numerous, connate below into a tube, longexserted, red or white; anthers minute; pollen in 2 or 4 masses in each cell. Style filiform. Pod linear, straight or nearly so, narrowed at base, compressed, the valves separating elastically from the apex downward.-Shrubby or woody only at base, mostly unarmed; leaves bipinnate with small leaflets (in our species); flowers in globose heads on axillary simple or racemose peduncles.-BENTH. \& HоOK. Gen. Pl, i, 596. 
glabrate: pinna 3 to 6 pairs, the lowest remote from the stem; leaflets 8 to 25 pairs, oblong-linear, acutish, a line or two long, strongly veined: peduncles solitary, a half to an inch long: corolla purplish, about 3 lines long, at least twice longer than the calyx: stamens about 30 : pods coriaceous, stipitate, somewhat hairy, 2 or 3 inches long by 3 lines broad, with very thick margins, 4-6-seeded.-Western Texas to Arizona and Mexico; Cañon del Diablo, Arizona, Loew.

Calliandra eriophylda, Benth. (l.c. iii, 105). (C. Chamadrys, Engelm. l. c.) -Shrubby, a foot high or less, appressed-pubescent and more or less villous: pinnx 2 to 7 pairs, the lower not distant from the stem, about half an inch long; leaflets about 10 pairs, oblong, obtuse or acutish, 1 to $2 \frac{1}{2}$ lines long, villous beneath or nearly glabrous: peduncles slender, solitary or in pairs, a half to an inch long: flowers purplish, more or less hairy: calyx short: corolla $2 \frac{1}{2}$ lines lung: stamens very numerous: pods as in the last, 2 to 4 inches long, pubeseent, 6-10-seeded.-From Westem Texas to Arizona and Mexico; at Camp Grant and Cottonwood, Ariz., Rothrock $(352,455)$.

\section{ROSACEA.}

Prunus Demissa, Walp.-My specimens were obtained doubtless from near where Fendler secured his. In some of its forms too close to $P$. serotina. No. 400 of the Colorado collection I have doubtfully assigned to this species.-Nevadia and Utah.

Nrillia* PAUCiflora, Benth. \& Hook. (Spirca opulifolia, $y$. panciflora, T. \& G. Fl. 1, p. 414.)-Differing from Neillia opulifolia (Benth. \& Hook.) in smaller leaves, fewer flowers $(5-10)$ to the corymb, and having usually less than four hairy carpels, and one to two mature ovaries. Still, however, it is quite variable. 402, from Mount Graham, has large leares, and 53, from Santa Fé, has as high as 14 flowers to the corymb.

Spirea millefolium, Torr. (Pacific R. R. Report, 4, 83, t. 5)."Woolly-tomentose; leaves oblong-lanceolate in outline, pinnate, with many pairs of small leaflets, pimn pimnatisect, or parted, oblong-linear, densely crowded with the very minute oblong divisions; flowers racemose-panicualbumen.

- Newlia, Don, differs from Spirca in inflated carpels, harder testa to the seeds, and nopious 
late. Ovaries 5, distinct, at first woolly; styles filiform. Mature carpels nearly glabrous; ovules $8-10$, pendulous from the upper part of the ovary" (Torr. l. c.).-Southern Nevada. Dr. Torrey remarks, "that the leaflets are almost as small and crowded as in Chamcebatia'; from this, however, it may at any stage be distinguished by the pleasant balsamic odor of the latter. Loew, Arizona (188).

Spirea discolor, Pursh, var. Dumosa, Watson, Nutt. (S. aricefolia, Smith, var. discolor, T. \& G.)-Mount Graham, Arizona, at 9,250 feet altitude (396), and Colorado (401).

SPIREA CEspitusa, Nutt-Utah.

Rubus Neo-Mexicants, Gray (Pl. Wright. 2, p. 55).-Shrub 5-10 high, unarmed, smooth and glandless; bark peeling away from the older branches, as in $R$. deliciosus; leaves round-cordate, longer than the petioles, 3-lobed, irregularly deeply and doubly serrate; stipules lance-ovate, nearly $\frac{1}{2}$ long, these with leaves and young shoots all canescently pubescent; calyx-lobes tipped with a conspicuous 3 -ribbed appendage; flowers white, $1 \frac{1}{2}$ in diameter; carpels red, densely agglomerated into a head; seeds conspicuously rugose-reticulate. As already remarked by Dr. Gray, it is very close to deliciosus, Torr--Mount Graham, Ariz., 9,250 feet altitude (397).

Rubus Deliciosus, Torr-LLeaves uniform-orbicular, rugose, 1-' $2^{\prime}$ in diameter, smaller somewhat than in preceding species; flowers white, $2^{\prime}$ in diameter; tips to the petals $\frac{1}{4}-\frac{1}{2}^{\prime}$ long, $1-2^{\prime \prime}$ wide, indistinctly ribbed.-Colorado (380).

Rubus Nutkanus, Mocino.-Utah.

Rubus strigosus, Michx.-Utah; Mosquito Pass, Colorado (388).

Purshia trinentata, DC.-Nevada and Utah.

Cerocarpus parvifolius, Nutt.-Colorado, at middle altitudes, along the valley of the Upper Arkansas (69, 980); Arizona.

Cerocarpus Ledifolius, Nutt. "Mountain mahogany."-Nevada and Utah.

Cowania Mexicana, Don.-Sanoita Valley, Southern Arizona, at 5,000 to 7,000 feet altitude (597); Nevada.

Dryas octopetala, L.-South Park, Colorado, at 12,000 feet altitude 
(399). Leaves oblong to subcordate, obtuse, crenately serrate, covered with a white tomentum beneath, and very veiny.

Falligia * Paradoxa, Endl.-Shrulos $2-5^{\circ}$ high, with young branches white; leaves $\frac{1}{2}-1 \frac{1}{2}$ long; leafless branches terminated by the whitish flower, which is an inch or more in diameter, or later by the dense head of carpels with thin, woolly styles. Calyx-lobes acute and usually reflexed after the petals fall.-Santa Fé 58), and Arizona, Loew.

Geum macrophyllum, Willd-Colorado (380); Utah; Loew, in Arizona.

Geum triflorum, Pursh-Colorado (394).

Geum rivale, L.-Colorado (381).

Gecy Rossir, Seringe.-Colorado, alpine, reaching as high as 13,500 feet $(385,387)$; Utah.

Fragaria Virginiana, Duchesne.-Colorado (402). Var. glauca, Watson.

Potentilla glandulosa, Lindl., var. Nevádensis, S Watson.-(379.) Collected in Colorado in 1873. It is a true P. glandulosa, Lindl., and hence the same as $P$. fissa, Nutt, differing from the above only in having more flowers in its less compact cyme. The Survey has it also from Utah.

Potentilla Rivalis, Nutt.-South Park (373).

Potentilla Pennsylvanica, L.-South Park and Twin Lakes, Colorado $(374,375)$; Utah.

Potentilla Hippiana, Lehm.-White tomentose throughout, $1^{\circ}$ high; leaflets $7-11$, decreasing regularly in size from the terminal one down, $\frac{1}{2}-1$ ' long, deeply and sharply serrate; 1-2 smaller leaves on the stem; bractlets a little shorter and petals a little longer than the sepals. Flowers yellow; styles terminal, filiform; carpels glabrous-Colorado (367, 209) and Arizona (220).

* Fallugia, Endl--Tube of the persistent ealyx ubconic-hemiepherical. At the apex 5-bracteolate; lobes 5, ovate; apex 3-dentate, or 3-cusp date, imbricated. Petals 5, large, obovate-rotund. Stamens many, inserted in a dense 3 -fold series; filaments filiform, united into a ring at the base; anthers small. Torns sulcate, villons, many carpels on the small conical receptacle; style terminal, villous; stigmas small; a single ascending ovule in the base of the cell, the many villose achenia termibated by very long, plumose styles. Seeil erect; testa membranaceous; cotsledons linear-oblong; radicle inferior.-An erect, much branched shrub, with virgate branchlets. Leaves alternate, petioled, irregularly 3-5-cleft or pinnatifid. Stipules adnate to the petiole. Flowers solitary on the apex of the branches, or sub-paniculate on elongated, leafless branches, bractless, ratber large._Bentham \& HookEr. 
Potenillua Plattensis, Nutt.-Sparingly covered throughout with an appressed silky pubescence, low, 4-8' long; branching from the root; leaves 2-4' long, pinnate, with 11-13 leaflets, each of which is cuneate in outline, and deeply eleft into 5-7 linear lobes; flowers in an open cyme, on long, slender pedicels, less than $\frac{1^{\prime}}{2}$ in diameter, bright yellow ; bractlets half shorter than the calyx-lobes; carpels rather indefinite, but about 30 ; styles filiform and terminal-Twin Lakes, Colorado $(346,377)$.

Potentilla gracilis, Dougl.-Colorado $(368,372)$; Utah.

Var. RIGIDA, Watson.-A larger and more villose form, with loose inflorescence, and larger, more veiny leaves. Same variety also from Utah.

Potentilla dissecta, Pursh.-Low, alpine, villose, with soft, spreading hairs, or glabrous, usually decumbent, $3-10^{\prime}$ long; leaflets $3-7$, pinnate or digitate, glaucous, cuneate-oblong, serrate or even pinnately cleft, with the divisions tipped with long, whitish hairs; receptacle very villous; style filiform, terminal.-Colorado $(371,378)$.

Potentilla humifusa, Nutt.-Spreading, herbaceous, perennial; leaves densely white tomentose on the under surface, greener and villose on the upper surface; leaflets $3-5$, cuneate-oblong, with 3-5 rounded teeth at the apex of each leaflet; stems ferw-flowered, 3-4' long; calyx-lubes larger than the bractlets; both calyx and bractlets densely villose; petals $2^{\prime \prime}$ long; styles terminal, filiform.-Colorado (365).

Potentilla nivea, L.-Colorado (366).

Potentilla Thurberi, Gray (Pl. Nov. Thurb. p. 318).-Herbaceous, perennial, 1-2 ${ }^{\circ}$ high, ascending, loosely villose, with long, spreading hairs; leaves digitate, upper sessile or nearly so, lower petioled, commonly 5-, sometimes 7-foliolate; leaflets obovately-cuneiform, regularly, deeply, and sharply serrate, lower surface canescent and villose gray or white, upper puberulent and green (smoother when old); stipules lanceolate or ovate, united to the petiole for one-fourth their length; bractlets lanceolate, acute, about as long as the sepals, though somewhat narrower, more or less villose; petals deep purple, broadly obcordate, about as long as the sepals; style terminal; carpels glabrous; disk thickened somewhat, 5-angled, with an inner circle of 5 stamens, with rather fleshy filaments inserted (one) on each angle; outer stamens with more filiform filaments; receptacle 8 BOI 
lairy- $\Lambda$ sh Creek, Arizona, at 5,225 feet altitude (310), and Mount Graham, Arizona, at 9,250 feet altitude (399). The form from Mount Graham is decidedly the more villose.

Potentilla fruticosa, L.-Colorado (383). Var. Aipina, Watson."Low and compact, the leaves very short (2 lines long), linear and revolute; same as 342 . [Watson in vol. v, King's Report], Utal."

Potentilla Anserina, L.-Utah; Colorado (382).

Sibbaldia Procumbens, L.-Colorado, at 11,000 feet altitude, (403). Though Torrey and Gray (Fl. N. Amer.) state the only difference between Silbaldia and Potentilla is in the minute petals and fewer pistils and stamens of the former, and thoughı Bentham and IIooker (in Gen. P'lant.) do actually unite these genera, I have refrained from following so reliable authorities, because Mr. Watson has excluded Silbaldia, IIorliclia, and Ivesia from his revision of Potentilla. At the same time I do not hesitate to express my opinion that the distinction between Potentilla and Silbaldia will not stand.

Ivesis* Depauperats, Gray (in Herb.) and Brewer and Watson (in Fl. Cal.). Potentilla depauperata, Engelm. (Gray, in Proc. Am. Acad. vol. vii, p. 399).-Willose throughout, $1-1 \frac{1}{2}{ }^{\circ}$ high; stem-leaves with 10-20 pairs of leaflets, $2-4^{\prime \prime}$ long, $2^{\prime \prime}$ wide, 3-lobed or parted, thickish, villose-pubescent; inflorescence cymose-paniculate; bractlets about half as long as the purple calyx-lobes; stamens 5; filaments filiform, opposite the calyx-lobes and in the sinuses of the adherent, 5-angled disk; ovaries 2 , or frequently 1 aborting as the other developes, immersed in the disk, the mouth of which is filled with erect, rather stiff, white hairs.-San Francisco Mountains, Arizona (369, Loew).

Ivesis Gordoni, Torr. \& Gray.-Buffalo Peak, Colorado, 12,000 feet altitude (386). One single location found, and only a few specimens, in a clump of Geum Rossii.

Chamerhodos f erecta, Bunge--2-4' high, villose pubescent, branch-

-Ivesia, T. \& G.- "Calyz campanulate, or eyathiform at base, 10-cleft. Stamens definite (5, 10, $15,20)$; filaments slender, narruwly subulate or filiform. Carpels few, sometimes solitary, apon a small villous receptacle; style subterminal. Leaves finnate, leaflets very numerous, small, palmate or pedately-parted, closely crowded, sometimes quasi-verticillate or imbricate on all sides of the rachis; petals broadly obovate, scareely unguiculate, becoming spatulate."-Gisy, P. oc. Am. Acad. vi, 530.

†Симденороs, Bunge,-Calyx without bractlets, 5 erect lobes, valvate. Stamens short, opposite to the petals. Disk lıning the calyx-tube, the margin with a thick crown of rather rigid hatis. Achenia $5-10$; styles axising from vear the base of the ovaries, where they are articulated, decidu. us, slightily 
ing from the root; radical leaves on petioles an inch long, ternately divided and many-cleft; segments linear, obtuse, cauline, 3-5-parted. Petals small, 1-2" long, spatulate, equalling or exceeding the sepals - Colorado (703, $876)$.

Agrimonia Eupatoria, L.-Collected by Professor Loew, but neither date nor locality given. Probably from Arizona or New Mexico.

Rosa Blanda, Ait. Colorado (391); Utah. Var. $\beta$ (Fl. N. Am. T. \& G. 1, p. 460).-With leaflets smaller and some of them puberulent beneath; appendages to the calyx-lobes are also somewhat smaller than in the average R. blanda. From the solitary specimen I have I should be inclined to con . sider it a distinct species.-Willow Spring, Arizona, at an altitude of 7,195 feet (236).

Rosa Arkansana, Porter (Fl. Col., p. 38).- "Stem stout, erect, leafy, $1^{\circ}$ high, glabrous and glaucous, armed with weak, deciduous, bristly prickles; leaflets 9-11, ovate and oblong-ovate, $1^{\prime}$ or more in length, acute or obtuse, glabrous, sharply serrate; midrib and long stipules somewhat prickly and minutely glandular; flowers numerous, terminal, corymbed on peduncles, about 1' long; fruit globose, smooth, glaucous; calyx-segments ovate, reflexed in fruit, with terminal and sometimes lateral appendages, more or less glandular and tomentose-pubescent on the margins; petals broadly obcordate or emarginate, longer than the calyx-segments; flower $2^{\prime}$ in diameter" (Porter, l. c.). This, as remarked by. Professor Porter, may only be an extreme form of $R$. blanda; to which it has been referred by Crepin - Twin Lakes, Colorado (390).

Rosa Fraxinifolia, Bork.-Differs from R. blanda chiefly in the greater size of its leaflets and fruit; the former being sometimes $1 \frac{1}{2}^{\prime}$ long and $1^{\prime}$ wide, and the latter " $6-8$ " in diameter". The flowers are also larger and the pubescence greater, though in these respects this species varies widely. I am indebted to Dr. Vasey for calling my attention to the fact that this (393), which I had placed under $R$. blanda in the Enumeration of Colorado Plants (1874), is a different species. This is now placed by Mr. Watson, in Index Am Bot. p. 312, under R. Nutkana, Presl.-Colorado.

capitate, single ovale ascending from the base of the cell; raticle enperior.-Glandular pilose herlos with woody bases, and with short, leafy brunches. Stipules adnate to the peticle. Flowers white or purple.-Bentuam \& HoOKek. 
Rosa Californica, Ch. \& Schl.-The Survey has specimens from Nevada and Utah, which, according to Mr. Watson, are the same as those considered by him in King's Report as $R$. blanda.

Amelanchier almifolia, Nutt.-Colorado (396); Nevada.

\section{SAXIFRAGEA.}

Saxifraga Hirculus, L.-Stem 2-8' high, strict, and with lanceolate, entire leaves (at base 3-6" long), regularly diminishing in size to the summit of the stem; pedicels and summit of the stem more or less densely clothed with a rusty tomentum (nearly glabrous sometimes); flowers 1-4, yellow, $5-8^{\prime \prime}$ in diameter ; sepals obtuse, reflexed, and one-fourth as long as the petals.-Twin Lakes, Colorado (799).

Saxifraga curysantha, Gray (Proc. Am. Acad. xii, p. 83). (S. serpyllifolia, Gray, in Report of Wheeler's Survey, 1874.) Perennial, stolons creeping, leafy, filiform; leaves at base of scape spatulate, obtuse, 2-4" long, entire, thickish, shining, midrib indistinct; scape, 1-2-flowered, 1-3' high, slender, with 2-6 bract-like leaves; flowers bright yellow, 6-8" in diameter; petals sessile or with a very short claw, truncate at base, rounded at apex, 2-3 times longer than the reflexed sepals; slightly 2 -lobed capsule broad-ovate.-Silver Heels Mountain, Colorado, at 12,000 feet altitude (799 bis).

Saxifraga flagellaris, Willd.-South Park, Colorado, at 12,500 feet altitude (797).

Saxifraga bronchialis, L.-Stems ascending, 1-6' high, from among the old leaves of the previous year; radical leaves lanceolate, acute, densely crowded, and ciliated with projecting, cartilaginous hairs, mucronate, $3-\tau^{\prime \prime}$ long. Stem-leaves linear, less ciliated, and somewhat appressed to the stem ; flowers corymbose, with a bract at each branch of the corymb; petals white, spotted with purple, exceeding the sepals-Twin Lakes, Colorado (802).

Saxifraga adscendens, L. (S. controversa, Sternb.)-Low, 1-2' high ; root-leaves clustered, somewhat cuneate at base and 3-parted at the apex; short stems with a few bract-like leaves, few-flowered; calyx-lobes obtuse, not lenger than the tube; petals yellowish white, a little longer than tho 
calyx; entire plant more or less glandular puberulent, though sometimes almost smooth.-Mountains of Colorado (798).

Saxifraga punctata, L. (S. cestivalis, Fisch.)-Colorado, moist, shady ravines, at 11,000 feet altitude (803); Utah.

Saxifraga nivalis, L.-Same as our Eastern S. Virginiensis, Michx. Colorado, 10,000 feet altitude.

Saxifraga integrifolia, Hook. (193, S. nivalis, var., Parry, IIall \& Harbour Coll., 1862.)-Half-Moon Creek, Colorado, in damp cold ground, at 11,000 feet altitude (796).

Tellima tenelua, Walp. Rep. (Lithophragma, Nutt.)-Colorado, west of the main range $(800,982)$.

Heuchera sanguinea, Engelm.-1-2 ${ }^{\circ}$ high; scape smooth, naked, or with one or two small, bract-like leaves; leaves clustered near the ground, on petioles 1-3' long, round, cordate at base, indistinctly 5-7-lobed, with lobes again divided; margins ciliate and roundish, teeth mucronate-pointed; petiole and midrib pilose; flowers paniculate, deep red; lobes of the calyx obtuse, denticulate; petals slightly exserted, nearly round, denticulate; stamens and style included-Limestone ledges, Sanoita Valley, Arizona, at 5,000 feet altitude (673). A very showy plant, and well worth cultivation.

Heuchera Rubescens, Torr. (Stansb. Rep. p. 388, t. 5).-Mount Graham, at 9,000 feet altitude (411).

Heuchera parvifolia, Nutt.-Colorado (804, 805), and rocky banks on Santa Fé Creek, New Mexico (61).

Parnassia fimbriata, Koenig.-Twin Lakes, Colorado (65).

Jamesia Americana, T. \& G.-Colorado, at middle altitudes, in rocky places (68), and near Santa Fé, N. Mex. (50).

Ribes oxycanthoides, L. (South Park, Colorado, 8, 11), is, according to Brewer and Watson (Fl. Cal. 1, p. 206), R. hirtellum, Mich.

Ribes leptanthum, Gray (Pl. Fendl. p. 53).-Poncho Pass, Colorado, Utah (4 and 7).

Ribes lacustre, Poir., var. Setosum, Gray.-Differing from the species in its hispid fruit, prickly young branches, fewer-flowered racemes, and smaller leaves.Colorado (3). 
Ribes cereus, Dougl.-Widely diffused. The expedition has it from Colorado (6), Zuni Mountains, New Mexico (176), and Nevada. The specimens from the Zuni Mountains exactly resemble those collected in 1851 by Sitgreaves' Expedition, and identified by Dr. Torrey.

Ribes viscosissimum, Pursh.-Utah.

Ribes aureum, Pursh.-San Luis Valley, Colorado (10). Northern Nevada also.

Ribes aureum, Pursh, var. tenuiflorum, Torr. (Ribes tenuiflorum, Lindl.)Distinguishable by liaving snaller flowers and fruit than aureum proper, yet closely shading into it.-New Mexico (109). Specimens insufficient.

Ribes WolfI, Rothrock (in American Naturalist, June, 1874). ( $R$. sanguineum, Pursh, var. variegalum, Watson, King's Report, vol. v, p. 100.) - 2 to 4 feet high. Neither prickly nor spiny. Moderately branclıing. Young branches light brown, minutely glandular-pubescent, somewhat angular by two ridges continued from the edges of the expanded bases of the petioles above. Branches of the previous year ashy-gray, with a deciduous epidermis, which, on being shed, shows the bark underneath dark brown.

Leaves cordate-orbicular, deeply 5 -cleft; lobes rather obtuse, unequally serrate, though hardly doubly serrate (average diameter of the largest leaves 2 to $2 \frac{1}{2}$ inches; depth of sinus at base in largest leaves $\frac{1}{2}$ inch), slightly viscid; under surface with a few glandular hairs, pale green; upper surface smoother and deeper green; petioles in fully developed leaves from 1 to $1 \frac{1}{3}$ inches long, margined by a continuation of the veins of the blade, expanded at base and becoming semi-amplexicaul, frequently strongly pectinately ciliate and glandular.

Peduncles 1 to 2 inches long, decidedly glandular-pubescent, 4- to 10flowered; bracts ovate-spatulate, obtuse, yellowish-white (occasionally verging toward red), 1 to $1 \frac{1}{2}$ lines long and 1 line shorter than the pedicels, which are a little longer than the flower.

Sepals red, lanceolate, obtuse, $1 \frac{1}{2}$ lines long, never reflexed; petals red, ovate-spatulate, half as long as the sepals, equalling the stamens; styles two, distinctly conical from the top of the ovary, red for half their length, parted to or below the middle, recurved; stigmas slightly capitate. 
Young fruit strongly glandular hairy, but never prickly, becoming smoother with age; mature fruit maroon or reddish-purple, globose, threeeighths of an inch in diameter, few- to many-seeded, edible; seeds distinctly wing-margined, with the inner coat, as seen through the gelatinous covering, longitudinally dotted.

It will be seen that this plant approaches both $R$. glutinosum, Benth., and $R$. sanguineum, P'ursh, though its nearer affinity is with the latter. It is distinguished from the former in being fewer-flowered, having shorter racemes and a rounder berry, and from the latter by its shorter racemes, relatively shorter bracts and longer pedicels, and erect calyx-lobes. It may prove to be a mere variety of $R$. sanguineum, though I think it sufficiently distinct to bear the name of its zealous discoverer, Professor Wolf.

Habitat.-Rocky places, at Twin Lakes and Mosquito Pass, at an altitude of from 10,000 to 11,000 feet.

\section{CRASSULACE $\mathrm{E}$.}

Tillea angustifolia, Nutt-Twin Lakes, Colorado (972, 326).

Sedum Rhodiola, DC.-South Park, Colorado (771).

Sedum Wrightir, Gray.-2-6' high; stems ascending from a decumbent base; radical leaves $2-4^{\prime \prime}$ long, obovate-spatulate, slightly pulverulent, margin whitish, very slightly denticulate; stem-leaves (and stem) purple-tinged, lanceolate, $3-5^{\prime \prime}$ long; inflorescence densely cymose, secund; petals 5 , white, with a tinge of red, apiculate, twice as long as the obtuse sepals; carpels abruptly contracted into a long, slender style-Mount Graham, Arizona, at 9,000 feet altitude, sending its fibrous roots down into the crevices of the damp rocks (756).

Sedum rhodanthum, Gray.-Colorado (769, 326).

Sedum stenopetalum, Pursh.-South Park, Colorado (770).

\section{HALORAGEA.}

Hippuris vulgaris, L.-Colorado, not rare (118).

Callitriche verna, L.-Twin Lakes (314).

Callitriche autumalis, L.-Rio Grande at Loma, Colorado (987). 


\section{LYTIIRARIET.}

Cupiea Wrightir, Gray (Pl. Wright. 2, p. 56).-Annual, 6-12' high, unbranched; stem, pedicels, and capsules viscidly pubescent or hispid; leaves lanceolate to oblong, 6-10" long, petioled, gradually reduced to bracts, glabrous or nearly so ; flowers either solitary or two or three in the axils; calyx with an inconspicuous spur, $3^{\prime \prime}$ long, naked in the throat; pedicels $3^{\prime \prime}$ long; purple petals hardly 2". long; stamens included; anthers, style, and seed smooth.-Sanoita Valley, Arizona (630).

Lythrum alatum, Pursh, var. lanceolatum, T. \& G.-- "Leaves lanceolate or elliptical, mostly opposite or whorled, acute at the base, often a little petioled, the upper ones much crowded, often shorter than the flowers" (T. \& G. Fl. N. Am. p. 481),-Nevada.

Var. hinearifolium, Gray. (L. Californicum, T. \& G.) - I have a set of specimens (309) from Ash Creek, Arizona, differing, so far as I can sce, from this form in nothing except that the accessory calyx-teeth are not quite obsolete.

\section{ONAGRARIE E.}

Epilobitim angustifolicm, L.-Colorado (143); Mount Graham, Arizona, at 9,000 feet altitude (438).

Epilubium latifolium, L.-Twin Lakes. Altitude, 9,600 feet. Wet, rocky places. August. We have in the collection the extreme forms of broadly lanceolate and narrow, lanceolate-linear leaves, with all gradations between. (142.)

Lilomium tetragonum, L-Twin Lakes, Colorado (145, 153, 156); Nevada and Utah.

Epilobium coloratum, Muhl-Colorado (154).

Epilobium palustre, L. var. $\beta$. albiflorum, T. \& G.-(156 bis.) These specimens were intermixed with 156 in the retained collection. So plainly marked were their characteristics-i.e., leaves entire, lance-linear, obtuse; stem few-flowered; flowers almost white; capsule hoary, at first almost sessile, afterward with a long pedicel-that I am half inclined to keep the form distinct as a species. Except for its manifesting little or no tendency to branch, it would be exactly E. rosmarinifolium of Pursh, Fl. 1, p. 259.South Park, Colorado. Altitude, 9,900 feet. 
Epilobium paniculatum, Nutt-Utah; San Luis Valley, Southern Colorado, at 6,400 feet altitude.

Zauschneria Californica, Presl_-Extending from California to Eastern Arizona.

Gayophytum ramosissimum, T. \& G.-Nevada; Colorado $(150,146$, 147).

Gayophytum racemosum, T. \& G.-Utah.

CEnothera biennis, L.-Utah and San Luis Valley, Colorado (131, 141). Var. grandiflora, T. \& G.-Nevada.

Var. hirsutissima, Gray. (E. Hookeri, Torr. \& Gray.)-Close to the last-i. e., var. grandiflora-but with a very lirsute ovary.-Sanoita Valley, Arizona (658).

CEnothera sinuata, L., var. grandiflora, S. Watson.-A poor specimen of what I take to be the above is found in the collection from Arizona, though I find it has hardly free tips to the calyx-lobes, and the flowers are nodding in the bud; seeds not seen. In this and the next species, there is a great difference in the length of the styles in plants from the same immediate locality, though it hardly suggests the idea of dimorphism.

CEnothera pinnatifida, Nutt.-Usually erect and somewhat branched, canescently pubescent and more or less hirsute; lower leaves petioled, entire, serrate or pinnatifid, upper ones linear-lanceolate, deeply and somewhat irregularly pinnatifid ; capsule sessile, linear, tapering, hirsute, $1^{\prime}$ long; calyxtube slender, dilating gradually, $2^{\prime}$ long; petals white or rose color, $1^{\prime}$ in diameter; calyx-lobes reflexed, not more than $1^{\prime}$ long, tips hardly free; seeds yellow, strongly pitted, slightly apiculate and oval.-Southern Arizona $(318,377)$; Colorado (125).

(Enothera trichocalyx, Nutt.-Erect, $4^{\circ}$ high, tomentose or somewhat canescent, hirsute; leaves sessile, tapering (in my specimens) into a petiole, oblanceolate, sinuate, denticulate ; capsule sessile, linear, tapering upward slightly ; seeds in a single row ; calyx-tube $1{ }_{4}^{3}$ long, calyx-tips free, throat naked ; petals yellow, $1 \frac{1}{2}^{\prime}$ long. Mr. Watson, to whom I am so greatly indebted, doubtfully assigns this rather rare plant here, adding in his remarks that it is 1068 of Wright.-Willow Spring, Arizona, at 7,195 feet altitude (223). 
Evothera albicaulis, Nutt.-Utah.

Var. Runcinata, Engelm.-Glabrous or eanescently pubescent, much branched, often from the decumbent base; leaves sessile, or nearly so, narrowly lanceolate, sometimes entire, but more frequently runcinately pinnatifid in their whole length.-Arizona, Dr. Oscar Loew.

Exothera coronopifolis, T. \& G.-Twin Lakes, Colorado, at 9,500 feet altitude (126).

CEnothera rosea, Ait.-Slender, branching from the base, sparingly puberulent; leaves lanceolate, tapering rather gradually to the apex, attenuated into a petiole $\frac{1}{4}^{\prime}$ long, entire or repandly denticulate; capsule ovate, 4-angled and 4-ribbed, 3-6" long; calyx-tube $4^{\prime \prime}$ long, longer than the lobes; petals bright rose color, equal to or somewhat shorter than the calyxtube; seeds nearly smooth.-Cienega (near Tucson), Ariz. (563).

CEnothera cespitosa, Nutt-Acaulescent, or with a very short stem, about $5^{\prime}$ high, more or less hirsute, especially on the margins and principal veins of the leaves; leaves broadly lanceolate, $2-8^{\prime}$ long, attenuate into a long petiole, rather acute, irregularly and sometimes deeply sinuate-toothed; calyx-tube 2-5' long, tips of the lobes united in the bud; capsules oblong, over an inch in length, strongly ribbed; "seeds in 2 rows in each cell, ovaloblong, not angled, very minutely and densely tubercled upon the back with thin flattened processes and with a narrow, longitudinal furrow on the ventral side."-South Park, Colorado, at 9,900 feet altitude (132).

Evothera triloba, Nutt-Calyx-tube 2-7' long; tips of the lobes free; petals obovate, $\frac{1}{2}-2^{\prime}$ long (the specimens giving so unusual a size of flower were from Willow Spring, Arizona); capsule 4-toothed, at the apex broadly 4 -winged; seeds 1-1 $\frac{1}{2}$ " long, angled, obscurely but densely tuberculate.-Willow Spring, Arizona (239); Denver and Twin Lakes, Colorado (123).

Genothera Nuttalli, T. \& G.

CEnothera heterantha, Nutt.-Utah.

Enotuera Hartwegi, Benth.-Suffruticose, usually about a foot high, branched (especially above); bark frequently shedding, as in $E$. Californica, pubeseent, though sometimes glabrous; leaves lanceolate, entire or irregulitly repaudly denticulate, somewhat ciliate, $8^{\prime \prime}-1 \frac{1}{2}^{\prime}$ long; calyx-tube variable, 
about $2^{\prime}$ long, broad in the throat; petals yellow, C-: $2^{\prime \prime}$ long; capsule $\frac{1}{2}-1^{\prime}$ long, hairy, though attenuated toward the base; seeds oval, indistinctly tuberculated; stamens shorter than the petals ; stigma discoid.-Camp Bowie, Ariz. (460). Var. lavandulefolia, S. Watson. (Enothera lavandulafolia, T. \& G.)-Much smaller; leaves linear, hairy, obtuse, 4-12" long; calyxtube much more slender and the "calyx-segments less attenuated above". Collected by Dr. Loew in Arizona. Widely different in appearance. Var. Fendleri, S. Watson, may be usually known at a glance by being glabrous, having oblong lanceolate leaves and larger flowers, with a broad throat. It comes from the same region.

CEnothera Greggir, Gray (Pl. Fendleri, p. 46).-_"Scarcely more than a variety of the last. More shrubby and diffuse, low, viscidly pubescent or more or less hirsute; leaves ovate to oblong, 1-3' long, acute, mostly sessile; flowers mostly terminal, calyx-tube slender, $8-15^{\prime \prime}$; petals acutish, 3-6" long, capsule $\frac{1}{2}^{\prime}$ long."-(Watson, Proc. Am. Acad. viii, p.

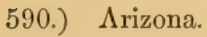

CEnothera alyssoides, Hook. \& Arn.-Utah.

CEnothera Boothi, Dougl--Nevada.

CEnothera scapoidea, Nutt.-Utah. Also, var. purpurascens. "Flowers larger, pinkish-white or purplish, rarely yellow, tube $2-3^{\prime \prime}$ long; petals $3-4^{\prime \prime}$ long."-(Watson.) Nevada.*

Gaura coccinea, Nutt.-Perennial, from a woody root, canescent; leaves lanceolate or linear, entire or irregularly sinuate dentate, $\frac{1}{2}-1 \frac{1}{4}^{\prime} l o n g$; bracts persistent, about as long as the mature fruit; reflexed calyx-lobes a little longer than the tube; style pilose at base; stigmatic indusium annular, margin entire or nearly so; fruit canescent, contracted in its lower third into a thick terete neck.-Nevada, Arizona, and Colorado (160, 161). Smooth form (159), Colorado.

Gaura sp. ?, No. 233.-Willow Spring, Arizona, 7,195 feet altitude. In the absence of proper fruit, on which I must depend to aid in assigning this specimen to a place, I felt inclined to regard it as merely a form of $G$. coccinea, which the structure of the flower much resembles. Dr. Gray (who

"It is but just that I should state (what is, however, obvious) that in descr,bing the species of Enothera I have drawn largely upon Mr. Watson's admirable monograph of the genus. See Proc. Am. Acad. rol. viii, pp. 573-618. 
las it, without fruit, from Dr. Palmer, obtained in New Mexico) is inclined to regard it as G. Drummondii. I believe it will prove distinct from either, in which case it might appropriately bear the name of G. Palmeri.

Gaura parvifolia, Torr. (in Ann. Lye. New York, 2, p. 200). (G.coccinea, Nutt., var. of T. \& G.)-Perennial, much branched from the base; branchlets, leaves, and fruit hoary puberulent; leaves $\frac{1}{4}-\frac{3}{4}^{\prime}$ long, linear, irregularly and sparingly denticulate; calyx-tube $3-5^{\prime \prime}$ long, a little longer than the lobes; stigmatic indusium decply 4-lobed, and slightly folded around the lobes of the stigma; appendages to the filaments rather large, $1^{\prime \prime}$ long; mature fruit suddenly contracted into a thickish neck at its lower third, above acutely 4-angled, intervening faces deeply concave, apex obtuse, acute, or even apiculate; style at base slightly villose. Evidently the nearer affinity of this plant is with $G$. coccinea, but since in addition to its smaller leaves the stigmatic indusium is constantly 4-lobed, I feel bound to keep up the distinction and restore the old name. The bracts too are smaller than in G. coccinea, and not caducous as in G. Drummondii, to which it has also some points of resemblance.-Cottonwood and Camp Grant, Ariz. (349).

Gaura suffulta, Engelm. (Pl. Lindh. p. 196) $-1-2^{\circ}$ high, villose, hearded with long, spreading hairs; branchlets, flowers, and bracts glabrous; leaves smoothish, lanceolate, attenuated at either end, repand-denticulate, lower ones broader, petioled; rachis roughened by the adnate pedicels from which the fruit has fallen; fruit ovate-pyramidal, glabrous, acutely fourangled, sides concave and hardly roughened. Flowers sometimes trimerous; appendages at the base of the filaments rather large; stigmatic indusium 4-parted and free (its tips at least) from the stigma.-Arizona.

Gaura Parviflora, Dougl.-Valley of the Gila, Arizona (768); Utah.

\section{LOASEA.}

Cevallia * sinuata, Lagasca--Genus of a single species so far as known.-Limestone rocks, Camp Bowie, Ariz. (480). Stings the hand like a genuine nettle.

- Cevillis, Lag.-Tube of the plumose calyx sbort, obloug; 5 linear lobes erect. Petals 5 , plumose, ereet, as long as and similar to the sepals. Stamens 5, erect, filaments very short; authers 
Petalonyx Thurberi, Gray (Bot. Mexican Boundary, tal. 22).-Southem Nevada.

Petalonyx nitidus, Watson (Amer. Naturalist, 7, 300).-Differing from the above in having its leaves distinctly petioled, serrate, "vitreous and shiny" and nearly alike in size (1-1 $\left.\frac{1}{4}^{\prime} \mathrm{long}\right)$ to the ends of the branches. Flowers also are in short, dense, cymose panicles.-Also from Southern Nevada.-Plate IV. Fig. 1. Branch nearly natural size. 2. Flower. 3. A single petal. 4. Diagonal section through pistil showing the single suspended ovule and two calyx-lobes. All except the branch enlarged.

Mentzelia nuda, T. \& G.-6-18' high, very rough, with short, almost cartilaginous bristles, usually branched from the root; leaves linear or lanceolate, nearly entire, or deeply pinnatifid; exterior filaments more or less dilated, antheriferous; petals nearly or about twice as long as the linear calyx-segments; seeds very numerous, winged, and somewhat flat.-Colorado (764, 765); Fort Wingate, N. Mex., Professor Loew, coll.

Mentzelia aspera, L.-Arnual; usually slender leaves, 3-lobed (the terminal lobe largest, irregularly toothed); petioles $4^{\prime \prime}$ long, slender ; flowers sessile or nearly so; petals $2^{\prime \prime}$ long, equalling the subulate calyx-teeth ; capsule $1^{\prime}$ long, regularly club-shaped. The few flattish seeds pendulous, under the lens marked with eurved longitudinal lines. Not winged.Sanoita Valley, Arizona, at 6,000 feet altitude (642). I had doubtfully named this $M$. albicaulis, Dougl., but from Mr. Watson's description in Fl. Cal. 1, p. 235, have assigned it here. Number 928 of Thurber's collection is in part the same, but is under $M$. albicaulis.

Mentzelia albicaulis, Dougl.-Colorado (768); Nevada.

Mentzelia lavicaulis, T. \& G.-Utah.

linear-oblong, pilose, 2-lobed at base, connective produced bejond the anther-cel.s into an elongated sub-iuflated process. Staminodia 0. Ovary inferior, 1-celled; style short, stigma ovoid. Solitary ovule hanging from tha apex of the cell. Frnit dry, indehiscent, oblong or obovoid, crowned by the calyx and corolla. Exalbuminons seed, conformed in shape to the cell; testa membranaceons, smootb; cotyledons amsgdaline; radicle very short.-Branchiug herbe, with the babit of Scabiosa, canescent-pubescent, setose, with lirger simple bristles arising ont of glands, smaller ones short, thick [transversely tubercular roughened]; bark white, shiuing. Sessile leaves alternate, sinuate-pinnatifid. Flowers terminating the poduncles, aggregated in hemispherical heads, silky hirsute. Involusre of linear-setaceous bracts.-BextiLM \& HoOKER. 


\section{CUCURBITACE $A$.}

Elaterium* Wrighti, Gray (Pl. Wright. 2, p. 61).-Stem slender, jubescent; leaves reniform or cordate, obscurely 5-lobed or angled; sinus deep; apex sometimes distinctly triangular-acuminate, slightly scabrous on the under surface and nearly smooth above; margin ciliate, and sometimes slightly and remotely denticulate; male flowers rather few, in a slender raceme, on capillary pedicels, abundantly covered with minute, globular, stalked glands (the pedicels of which are manifest on the margins of the corolla-lobes); corolla adnate to the calyx, the lobes of which are reduced to mere teeth; fruit $1-1 \frac{1}{2}^{\prime}$ long, $6^{\prime \prime}$ in diameter, covered with glandular, hairy prickles.-Cienega, Ariz. (581). Beyond doubt identical with 951 of Mex. Bound. Survey.

Apodanthera $\dagger$ undulata, Gray (Pl. Wright. 2, p. 60).-Trailing vine, several feet long. Fruit $3-\boldsymbol{1}^{\prime}$ in diameter.-Valley of the Rio Grande and Eastern Arizona (373).

Cucurbita $\ddagger$ digitata, Gray (Pl. Wright. 2, p.60)._-"Root large, fleshy;

- Elaterium, Linn.-Flowers monœcion8. Male flowers in a long raceme. Calyx-tube urceolate, rampanulate, or elongate-cylindrical. Corolla salver-shaped, tube short or elougated, inflated, or ryliuclical; lobes oblong, linear or lanceolate. Filaments united into an elongated column; anthe's rnited juto as small oblong or globose head; linear cells sigmoid, flexnose; connective sometimes froluced beyond the celle. No rudiment of an ovary. Female flowers solitary. Calyx and corolla as in the male flowers. No rudimentary stamens. Ovary obliquely ovoid, rostrate, hispid, or echinate, 1-6-cellerl, often 3-celled with 2 cells many-ovuled and the third empty, rarely 4-celled with one or two of them enipty, or with 4 small cells, 2 above and 2 below; style columuar or filiform, costracted nuder the large capitate stigma; ovules in cells 2-mauy, or a single ovule in each of the cellules. Fruit obliquely ovoid, rostrate, gibbous, fleshy, 1-many-celled ("debiscent at the apex," Gray). Seeds flat, with the margins often crenulate.-Annual, climbing herbs, smooth or 1 ubescent. Leaves cordate, entire, lobed or parted. Tendrils 2-3-parted.-BentHam \& Hooker.

tAponnturna, Arn.-Flowers morœcious or diœcione. Male flowers racemose. Tube of the calys funnel-shaped or cylindrical, dilated at the base, lobes 5, subulate. Corolla rotate, deeply 5-parted; segments oblong or linear. Stamens 3 or 4 , sessile in the throat of the calyx; anthers linear, counate in the middle; one, or two 1-celled, the remainder 2-celled, cells nearly straight, connective not prodnet d. No rudimentary ovary. Female flowers solitary. Calyx as in the male, bot more urceolate. Corolla like the male. No rudimentary Etamens! Ovary ovoid, with 3 placentas; style columuar, with a 3-lobe d fleshy stigma; ovules many, horizontal. Fruit fleshy, ovoid.-Climbing or prostrate berbs, pubescent or hispid. Leaves round, reniform, entire, or somewhat lobed. Flowers rather large, sellow.-BrNтHAM \& HOOKER.

†Cucurbrts, Linn.-Flowers monøcions, all solitary. Male flower:-Calyx-tube campanulate, rarely elongated, lobes 5; simple or foliaceous. Corolla campannlate, eleft to or below the midule. Apices of the lobes recurved. Stamens 3 , inserted in the botton of the calyx; filaments free; anthers linear, conflnent into a bead, one, 1-celled; two, 2-celled; cells elongated, siguoid dexnose. No rudjments of an ovary. Female flowers:-Calyx and corolla as in the nale. Three rndimentarj stamens in the bottom of the calyx. Ovary oblong, with 3 placentas; style short, stigmas 3, 2-lobert or forked; ovules many, horizontal. Fruit a berry, fleshy, often with a thek sind, indeliscent 
branches prostrate, running 10-20 feet." Segments of the upper leaves $2-4^{\prime \prime}$ wide and $3^{\prime}$ long; lower leaves wider and shorter, somewhat lobed. Corolla yellow, $3^{\prime}$ long, funnel-shaped-Arizona (441). Fruit $3^{\prime}$ in diameter, green, with white, longitudinal stripes.

\section{CACTE $\mathrm{A}$.}

\section{By Dr. George Engelmann.}

Mamillaria (Coryphantha) vivipara, Haworth, Engelm. in Watson's Bot. King's Expl. 117.-A common plant on the Western plains from the Missouri to Texas, extending in the mountain regions as far west as Arizona and South Utah, the large, deep rose-colored or purple flowers, with fringed sepals and lance-linear, acuminate petals, green, oval berries, with light brown, pitted seeds, readily distinguish the species. The form of the plains is lower and often densely cespitose-spreading; the mountain plant is often simple and larger. The largest form, which comes from Arizona, I had at one time distinguished as $M$. Arizonica, but must now consider it as only a gigantic vivipara, $3-5^{\prime}$ high, $4^{\prime}$ in diameter, with spines often over $1^{\prime}$ long on rather broad and spreading tubercles. Rothrock, 1874, (203), is a smaller form, from Camp Apache, Ariz.

Mamillaria (Cokyphantha) chlorantha, n. sp.-Similar to the last, but with broader yellow petals; stems oval to cylindrical, $3^{\prime}$ wide, sometimes 8-9' ligh; tubercles compressed from above; 20-25 outer spines gray, almost in 2 series; $6-8$ or 9 inner ones stouter, $\frac{1}{2}-1^{\prime}$ long, reddish or brownish only at the tip; flowers yellowish or greenish-yellow, crowded on the top of the plant, $\mathbf{1}^{\prime}{ }^{\prime}$ long and wide, often 1-2 small, fringed sepals on the ovary (which also occasionally is seen in vivipara); sepals lanceolate, fringed; petals lanceolate or linear-lanceolate, acute, denticulate; 7-9 whitish stigmas, erect-spreading.--Southern Utah, east of Saint George, Dr. Parry. I. E. Johnson.

Echinocactus Wislizeni, Engelm.-Very large, often over $3^{\circ}$ high and half as much in diameter; at first globose, then ovate to cylindrical,

and many-seeded. Seeds ovate or oblong. Stems annnal, roots perennial, often procnubent and rootiug. Leaves cordate at base and lobed. Tendrils 2-many-cleft. Flowers large, yellow. Fruit often very large.-BenthaM \& IIOOKEк. 
with 21-25 mather sharp rilss; the large linear-oblong areola (very woolly when young) bear three kinds of spines, first, 4 very stout, amnalated, reeldish ones, $1 \frac{1}{2}-21^{\prime}$ long, the 3 upper ones straight, the lower one hooked; second, 3-5 lower and usually 3 uppermost spines, slender, but straight, stiff, and amnulated, of reddish color; third, 12-20 whitish, bristle-like, flexuous, lateral spines: flowers 2-21' long, $1 \frac{1}{2}$ wide, yellow, outside greenish with purple-brown; ovary and finit imbricately corered with numerous (50-60) cordate or reniform crenulate sepals; sepals of tube oblong, ciliate; petals broadly linear, crenate, bristle-pointed; style deeply divided into 12-18 linear stigmas; secds $1^{\prime \prime}$ long or orer, reticulate or shallow-pitted.-Southern New Mexico.

Var. Le Conter. (E. Le Contei, Engelm.)-At last clavate from a slender base; lower central spine more flattened, curved or twisted, but not hooked; flower rather smaller and with fewer parts.-This is the Western form, from South Utah and Arizona to and beyond the Colorado River. Dr. Rothrock collected, at Camp Bowie, Ariz., a peculiar form (492), which may represent another variety, decipicns: globose, $1^{\circ}$ in diameter; spines shorter and ferver, no straight spines above the 4 central ones, none longer than 1-1 $\frac{1}{2}$ inches; $10-15$ thin flexuous spines on side and upper end of areolæ; only 20-25 sepals on ovary.

Echinocactus polycepualts, Engelm. \& Bigel. (see Watson in Bot. King's Expl.117).-From the Mojave region to Southwesteru Utal.. The numerous spiny-bristly sepals, and the linear, acute, yellow petals almost hidden in a dense cottony wool.

Echinocactus Whipplei, Engelm. \& Bigel; Watson, l. c. 116.-On the Lower Colorado River and northward into Utal.

Cerecs (Echinoccreus) Exarluanni, Parry; Watson, l. c. 117.Throughout Arizona and into Utah and Southern California. Flower purple, open only in mid-day sunshine.-Camp Bowie (1002), Mrs. Major Sumner. Flower only. May le this or an allied species.

Cereus (Echinocereus) phøxiceus, Engelm.-Globose or oval heads, $2-3^{\prime}$ high, about $2^{\prime}$ in diameter, several to a great many (sometimes over 100) from one base, 8-11-ribled; 8-15 slender, but straight, stiff, anıl very brittle spines in each bunch, $\frac{1}{2}-1 \frac{1^{\prime}}{2}$ long, $1-3$ of them more central and 
a little stouter; deep red flowers, $1 \frac{1}{2}-2 \frac{1}{2}^{\prime}$ long, half as wide, open equally day and night, spatulate, rather stiff petals, rounded at tip.-From West Texas to Southern Colorado and Arizona, as far west as the San Francisco Mountains, Bigelow, and from Fort Whipple, Palmer.

Cereus (Echinocereus) triglochidiatus, Engelm.-Few (2-5) globose or oval heads, 2-4' high, 2-21 thick, 6-7-ribbed; areolæ more distant than in the last; spines fewer, only 3-6, flattened or angular, usually curved, about $1^{\prime}$ long; flowers same as in last.-New Mexico, Santa Fé, 1874, Rothrock (39). C. gonacanthus, Engel. \& Bigel., which extends from New Mexico to the Arkansas River and westward to Zuñi, and is characterized by its stouter, longer, and rnore numerous spines, may belong to this species; and perhaps both, with numerous other so-called species, which vary only in the number of the ribs, the number or form of the spines, and the closeness of the spine-bunches, but have all similar flowers, may have to be considered as forms of one polymorphous type (C. phoeniceus).

Opuntia (Platopuntia) Basilaris, Engelm. \& Bigel.-A low plant, with broadly obovate, often retuse or fan-shaped joints, branching mostly from the base, pubescent, as well as the fruit; areolæ very close, without spines, but densely covered with short, yellowish-brown bristles; flowers large, rose-purple; fruit dry, subglobose, with rather few, large and thick seeds.-Southeastern California to Arizona. Distinct from all other species of this region by its mode of growth, its pubescence, the absence of spines proper, and the very large $\left(3 \frac{1}{2}-5^{\prime \prime}\right.$ wide) seeds. The large purple flowers, which in the season completely cover the plant, make a beautiful show.

Opuntia (Platopuntia) Missouriensis, DC.-Santa Fé, N. Mex., 1874, Rothrock (6). Common from the plains of the Missouri into the mountains. A low, very spiny (whence Nuttall's name, O. ferox) species, with yellow or sometimes (on the Upper Arkansas plains) purple flowers, and dry spiny pods, which contain large, much compressed, and broadly margined seeds.-Several more, probably half a dozen, flat-jointed Opuntia have been noticed in Arizona, some prostrate and with smaller joints; others tall, erect, with large joints (to a foot or more in length), many of them very spiny; of them not much is known, as the plants are difficult 9 BOT 
to preserve and flowers and fruit have not often been found or collected. Full notes, living joints, good fruit and seed, and pressed flowers are desirable, to make us sufficiently acquainted with these plants. The best method of preserving the flowers is to split them open before attenupting to dry them. Living plants or joints are very valuable, but alone are not sufficient, because in cultivation they very rarely flower and scarcely ever bear fruit.

Opuntia (Cylindropuntia) clavata, Engelm. $-\Lambda$ low, cespitose plant, with short (1-3' high, $1^{\prime}$ thick), clavate, ascending, strongly tuberculate joints, the upper areolæ bearing 4-7 ebony-white, flattened, striate spines, surrounded by a number of smaller, bristly ones; yellow flowers, $2^{\prime}$ wide; dry, yellow, oval pod, covered with numerous, large, woolly, and long-bristled areolæ.-El Rito, New Mexico, Rothrock, in 1874 (92). Also about Santa Fé, etc.

Opuntia (Cylindropuntia) pulchella, Engelm. (see Watson's Bot. King's Expl. 119; Simpson's Report, Botany, t. 3).-A very small, purpleflowered species of Nevada. A flower brought home by Mr. Bischoff was, by a singular error, enumerated in the Catalogue of 1874 as Cereus viridiflorus.

Opuntia (Cylindropuntia) arborescens, Engelm. (see Watson, $l$. $c$. 120).-Cuero, New Mexico (101), Rothrock, in 1874; Cienega, South Arizona (near Tucson), the same (584); and from Camp Bowie, Ariz. (1002), by Mrs. Major Sumner. This handsome species extends northward to the plains of Colorado and Pike's Peak, covering extensive tracts. Remarkable for its horizontal, often whorled, branches; purple flowers, $2-2 \frac{1}{2}^{\prime}$ in diameter; ovary often with some spiny bristles, which at maturity disappear. The skeleton, as the cactus wood is rather fancifully called after the soft tissues have rotted away, forms a heavy, hollow cylinder, with regular rhombic holes or meshes corresponding to the tubercles and spine-bunches of the plant, and makes excellent canes. This species is closely allied to the Mexican 0 . imbricata and 0 . decipiens, arborescens being the northern, larger-flowered form, but the seeds are different.

Opuntia (Cylindropuntia) Bigelovii, Engelm. (Pac. R. R. Rep. 4, 
Bot. 50, t 19).-An erect, bushy plant, 10-12 ${ }^{\circ}$ high, with oval or subcylindric joints, bearing on short oval tubercles $3-5$ large $\left(1^{\prime}\right.$ long) and many smaller spines, the larger ones loosely covered by glistening, whitish sheatlss; purple flowers, small, 1 inch wide; fleshy, greenish berry, numerous small and very irregular seeds, or often abortive; wood a wide, fragile tube with short meshes.

Opuntia (Cylindropuntia) tessellata, Engelm.-Very bushy, from a stout trunk, with solid wood, sometimes several inches thick; ultimate branches as thick as a swan's quill, covered with angular, flattened, ashygray tubercles, the uppermost bearing at their upper end single, long, loosely yellow-sheathed spines; flowers small (about $\frac{3}{4}$ of an inch wide), yellow; small fruit, oval, covered with long, soft, brown bristles. Pac. R. Rep. l.c. t. 21.- Un both sides of the Lower Colorado River, $6-7^{\circ}$ high; the yellow, shining spines, crowded on the upper end of each year's growth, together with the scale-like tubercles, give the plant a singular and striking appearance.

There are several other cylindric Opuntia in Arizona, not collected in these lixpeditions, and for the most part only imperfectly known. It is desired to direct attention to this interesting group, which, on account of the bulky forms and forbidding armament, are too much shunned by travellers.Opuntia echinocarpa, Engelm. \& Bigel., is a low and very spiny bush, with yellowish flowers and dry, spiny fruit. Opuntia acanthocarpa, Engelm. \& Bigel, is taller, with elongated tubercles, or rather ridges, copper-colored flowers, and dry fruit bearing few, but stouter spines. O. mamillata, Schott, and fulgida, Engelm. \& Bigel., are allied to O. Bigelovii, with thick tubercles or prominent crests, the former with small, the other with numerous long and shining, sheathed spines; fruit often abortive. Good specimens with flower, fruit, and good seed of the same plant (so that mixing species and forms may be avoided) are very desirable, as we know scarcely anything more about them than what the botanists of the Mexican Boundary Commission (often at the most unfavorable season) could find out, twenty-five years ago. Opuntia leptocaulis, DC. (O. frutescens, Engelm.), the most slender Opuntia known, bushy, with branches like pipe-stems, small yellow flowers, and red, somewhat fleshy berries, is common 
from North Mexico, through Texas, to Arizona. It has been said that its flowers, contrary to the habit of the genus (which has diurnal flowers-i.e., open in sunlight), are nocturnal, which, however, is now positively denied.

\section{FICOIDE正**}

Mollugo verticillata, L.-Point of Mountains, Arizona (723).

\section{UMBELLIFER AE.}

Eryngium Wrighti, Gray (Pl. Wright. 1, p. 78).-Erect, smooth, pale, somewhat branched; lower leaves narrowly spatulate, regularly pectinate or toothed, with each tooth terminating in a bristle; stem-leaves lanceolate, $3-5^{\prime}$ long, deeply cleft, with the divisions terminating in a bristle; upper leaves shorter, more deeply and palmately parted; petals blue, with a long, inflexed point; leaflets of the involucre longer than the head; inner bracts slightly exceeding the flowers.-Sanoita Valley, Arizona (603), at 6,500 feet altitude.

Musenium t trachyspermum, Nutt.-Branching from the base; radical leaves ascending, petioled, pinnately parted, with the segments pinnatifid; rachis broad, 1-2" ; fruit nearly as broad as long, and slightly roughened; involucel of 8-10 leaflets, 2-4" long, narrow, but slightly dilated upward.-Colorado (726).

Crcuta macui ata, L.-Nevada and Utah.

Carum Garrdneri, Benth. \& Hook.-Nevada, where, as in Utah, the tubers are an important article of food with the Indians.

"Ficordes.-"A miscellaneous group, chicfly of fleshy or sncculent plants, with mostly opposite leaves and no stipules; differing from Caryophyllacee and Portulacacee by having distinct partitions to the ovary and capsule (which are therefore 2-many-celled); the petals and stamens sometimes numerons in the mauner of Cactacece (but the former wanting in most of the genera); agreeing with all ibese orders in the campylotropous or anphitropous seeds; the slender embryo corved partly or completely round a mealy albumen."-Fl. Cal. p. 250.

† Museniom, Natt.-Calyz-teeth conspicuous. Petals clawed, obovate, point inflexed. Stylopodia small, depressed, styles ratber short. Fruit ovate, slightly compressed on the side, commissure rather broad; carpele 5-angled, a little compressed on the back, with the primary ribs filiform, rather prominent, lateral ones contiguons. Vittæ many. Carpophore bifid. Seed compressed a little on the back, with the sides a little incurved.-Perennial, cespitose herbs, branching from the base, snooth. Leaves pinnate or bipinnatifid, segmen:s pinnatifid. Many-rayıd umbel compound. Involucre none. Involueel of a few short leafletg. Flowers white or yillow.-Bentuam \& Hooker. 
Berula * angustifolia, Koch. (Sium angustifolium, L.)-San Luis Valley, Colorado, in hot springs, the temperature of which is $80^{\circ}$ Fahr., and in spring water at Fort Tejon, Cal,, where the water has a temperature of $62^{\circ}$ Fahr. In neither of these locations was there much of a yearly variation in temperature of the water, yet in one instance, as in the other, the plant grew luxuriantly, the difference in the temperature of the water at the two places being $18^{\circ}$ Fahr. $\quad(732,262$.)

Sium cicutafolium, Gmelin. (Apium lineare, Benth. \& Hook)-San Luis Valley, Colorado (730, 732).

Crmopterus alpinus, Gray.-Low annual shoots 2-5' high, from a perennial root; leaves bipinnatisect or bipinnate, segments $2-4^{\prime \prime}$ long, linear, acutish, glabrous, or very minutely puberulent; scape as long as or exceeding the leaves; involucels 5-7-parted, segments linear or lanceolate, as long as the flowers; calyx-teeth conspicuous, subulate; fruit thickish winged, with the marginal ones a little wider than the others; vittæ one in each interval and two on the commissure, all small. Flowers small, yellow.-I have taken the character of this fruit from No. 213 of Hall and Harbour. The material, moreover, is very scanty. If, however, the specimen examined by me is fairly a representative one, the resemblance between it and Enanthe is too obvious to escape attention, especially when we remember that with the other peculiarities it has no carpophore--Griffith's Peak, near Georgetown, Colo., at 11,500 feet altitude (725, 731); also accredited by Porter to Mount Lincoln, Colorado, at an elevation of 13,000 feet.

Cymopterus glomeratus, Raf.-3-8' high; caudex 1-2' high, branching from the summit; peduncles shorter than the leaves; leaves ternately divided, deeply bipinnatifid, on long petioles, which are dilated at base. Umbels on very short rays; involucels palmately parted, unilateral and sometimes coherent with the rays of the umbellets; flowers white; fruit in my specimen, No. 210, of Hall and Harbour, with marginal wings thin and expanded and with the dorsal ones only a little less so. I must confess my

* Berula, Koch.-Calyx-teeth minute. Stylopodium conical and styles short. Fruit nearly globose, with a broad commissure, emarginate at base, the ribs nerve-like, not raised above the thick epicarp; oil-tubes numerous and contiguons, surrounding the terete seed. Carpophore 2-parted, very slender.-A smooth, perennial aquatic; leaves pinnate and serrate ; involucres and involuccls of several leaflets; flowers white.-Fl. Cal., p. 260. 
inability to find any trace of earpophore, either free or allierent, to the carpels.-Denver, where in June it is quite common on the plains.

Ligusticum montanum, Bentham \& Hooker. (Thaspium ? montanum, Gray.)-1-2 ${ }^{\circ}$ ligh, often branched; leaves twice ternately divided; lobes linear, linear-lanceolate, or lanceolate, $9-18^{\prime \prime}$ long; petioles $1-4^{\prime}$ long, widely dilated into a sheath toward the base; fruit variable, oval or broadly oval, marginal wings broader than the others, or sometimes the dorsal as much dilated as the marginal; vittæ single or double in each interval; involucre none; involucels of 5-9 setaceous bracts, which are 2-4" long; flowers bright yellow.-Central Colorado, reaching as ligh as 12,000 feet altitude (716, 719, 720, 724), and in Arizona, at Willow Spring, at 7,195 feet altitude (253). In the majority of cases in my specimens, one carpel has entirely, or almost entirely aborted.

Ligusticum apinfolium, Benth. \& Hook.-Twin Lakes, Colorado (717).

Thaspium trifoliatum, Gray.-South Park, Colorado (727).

Axgelica Wheeleri, Watson (American Naturalist, 7, 301).—"Tall and stout, roughly puberulent, leaves biternate; leaflets ovate-oblong, $2-3^{\prime}$ long, acute, incisely serrate, the teeth broad and mucronate, middlo leaflets petiolulate; umbels naked; rays numerous, unequal, becoming $2-5^{\prime}$ long; pedicels and ovary hispid; petals apparently white; fruit broadelliptical, $3^{\prime \prime}$ long, sub-pubescent, the dorsal wings thick, narrower than the lateral ones, Utah."

Angelica lineariloba, Gray (Proc. Amer. Acad. vii, p. 347).-Southern Sierra Nevada, at 9,500 feet altitude (355).

Archangelica Greuini, DC.-Twin Lakes, Colorado (712).

Ferula multifida, Gray (?).-From Utah, the Expedition has simply the leaves of what Mr. Watson doubtfully refers here.

Prucedanum sativum, Benth. \& Hook. (Pastinaca sativa, L., Gray's Manual.)-Utah. Introduced.

Heracleum lanatum, Michx.-Twin Lakes, Colorado (713), and New Mexico? Hance.

CORNACEA.

Cornus pubescens, Nutt.-Utah. A specimen from Loma, Colorado, is doubtfully placed here. Specimens too poor. 
"Garrya* flavescens, Watson ( $\Lambda \mathrm{m}$. Naturalist, 7, 30:).-Silkyjubescent, with straight, appressed hairs ; leaves yellowish, elliptic-oblong, acute at each end, 1-2 $\frac{1^{\prime}}{2}$ long, glabrate above, entire, revolute on the margin; petioles $3-6^{\prime \prime}$ long; aments pendulous, the bracts broad-ovate, connate, foliaceous, acute or the lower ones acuminate, $6-10$ pairs ; sterilo aments rather loose, 1-2 inches long, the flowers $1-3$, on pedicels equalling or exceeding the ample bracts; fertile aments crowded, $1^{\prime}$ long, with solitary flowers and densely pubescent fruit.-From Southern Nevada and Utah to Arizona and New Mexico; growing $5-8^{\circ}$ high."

\section{CAPRIFOLIACE $A$.}

Adoxa $†$ Moschatellina, L.-Leaves mostly radical, 2-3' long, temately bi- or triternate, segments again trifid; flower-stems as long as, or longer than, the radical leaves, with a pair of trifid leaves. Head of about five greenish flowers terminating the stem, the terminal flower with fewer lobes to the calyx and corolla, and also fewer stamens than the lateral flowers. Berry green.-In shaded mountain ravines in Colorado, at 11,000 feet altitude.

Sambucus glauca, Nutt.-Willow Spring, Arizona (250); Utah.

Sambucus Mexicana, Presl.?-Camp Lowell, Ariz. (near Tucson); a small, much branched tree, $10^{\circ}$ high and $5^{\prime}$ in diameter; bark light brown; young branches and petioles densely canescent; leaves on the under surface less so, nearly glabrous above ; leaflets usually $5,1 \frac{1}{2}-3^{\prime}$ long, terminal one

* Garrya, Dougl. ex Lindl. Bot. Reg. t. 1C86.- Flowers diøcious; an ents between the united bracts. Male flowers, with a 4-parted calyx, with the sfreading linear segments valvate, apices sometimes cohering. Petals 0. Stamens 4, opposite or alternate to the sepals, filaments free; anthers fixed by the base, linear introrse or laterally dehiscent. Disk and rudiments of the ovary obscure. Female flovers, with the calyx-tube ovoid; lobes of the limb 2, opposite, short or obsolete. Rudiments of the stamens and disk 0. Ovary 1-celled; styles 2, filiform and erect, or short and recurved, longitudinally stigmatose within; ovules 2 , hanging parallel from the apex of the cell; funiculus elongated. Berry ovoid, crowned by the persistent styles, 1-2-seeded. Seeds oblorg, compressed, testa membranaceous, transversly rugose. Albumen copious, flesby; embryo cylindrical, minute, cotyledons oblong, radicle terete.-Shrubs, with 4-angled branches. Leaves opposite, petioled, entire or denticulate, peuninerved, evergreen, petioles connate at base. Flowers small, not articulated with the pedicelBENTH. \& Ноок.

† Adoxa, Linn. Gen. n. 501.-Leaves ternately divided. Calyx with two or three spreading teeth or lobes. Corolla with a very short tube, and 4 or 5 epreading divieions. Stamens 8 or 10 , in pairs, alternating with the divisions of the corolla, and inserted on a little ring at its base. St.yles 3-5, very short, united at the base. Ovary 3-5-celled, with one ovule in each cell. Fruit a berry.-Bentins, Hacduook of the British Flora. 
generally the largest, oblong, irregularly serrate to within $6^{\prime \prime}$ of the acute tip; infloreseence corymbose, "corymb 5-rayed"; stamens two-thirds as long as the petals; anthers oval or somewhat cordate. Fruit I have not seen. (712.)

Sambucus racemosa, L., var. pubens, Watson.-Clear Creek Cañon, Colorado.

Sxmphoricarpus rotundifolius, Gray (Pl. Wright. 2, 66).-“Leaves orbicular, or ovate-rotund, small and with the branches softly pubescent; flowers solitary in the axils; bracteoles shorter than the ovary, and with the teeth of the cup-shaped calyx ovate, obtuse and glabrous; corollit funnel-shaped, smooth within, lobes longer than the stamens. $3-4^{\circ}$ highl, much branched; leaves 5-9" long and nearly as wide, entire or often repand, petiole a line or less in length."-Nevada. Not having access to the specimen, I quote the above original description bodily from Pl. Wright. In vol. v, King's Report, Mr. Watson places this under S. montanus, II. B. K. Later, however, he keeps them apart in his catalogue published by this Survey in 1874, p. 10.

Symphoricarpus oreophilus, Gray (Revis. Symph. Jour. Linn. Soc. vol. xiv, p. 12).-Low, branching shrub, with a loose, grayish epidermis; leaves oblong, obtuse, sessile or nearly so, thickish, somewhat glaucous below, entire or slightly undulate; principal veins below more or less pubescent, $6-12^{\prime \prime}$ long and half as wide; inflorescence racemose along the short, lateral, leafy branchlets ; flowers rising from the axils of the leaves on short pedicels, which are terminated by a pair of minute bracts one-fourth as long as the mature capsule; ovary oval, constricted under the persistent calyx-lobes, which are $\frac{1}{2}$ ' long and very obtuse ; corolla cylindrical, 4-6" long, lobes $1_{2}^{\prime \prime}$ long, rounded, naked in the throat, but a little hairy inside toward the iottom; stamens included, on very short filaments rising just above the sinuses; anthers oblong, apiculate; stigma 2-lobed and one-third as long as the corolla-tube.-South Park, Colorado (18). Leaves smaller, but plant bearing a general resemblance to $S$. racemosus.

Linnea borealis, Gronov.-Twin Lakes, Colorado, at 11,000 feet altitude.

LONiCERA InVoLucrata, Banks.-Colorado (19). 


\section{RUBIACEA.}

Bouvanda * inttella, H. B. K., var. Quaternifolia. (B. quaternifolia, DC., Prod. vol. iv, p. 365).-Low shrub, often much branched; older shoots clay-colored, younger dark green and puberulent; leaves short-petioled, thickish, lanceolate to broadly oval, acute, commonly three in a whorl, sometimes more, or again reduced to two, opposite, slightly hispid on upper surface, nearly glabrous on lower (except on the principal veins), and ciliate on the margin, 1-2' long, 5-10" wide; corymbs trichotomous. Corolla 12-18" long, glandular puberulent, smooth or nearly so in the throat, lobes 1-2" long; stamens sessile, oblong and slightly emarginate at base; calyx covered with a short, stiff, white pubescence, tube half as long as the acutc, narrowly lanceolate lobes._Camp Bowie, Ariz., at 5,500 feet altitude (478). I can find no description that exactly answers for this plant, yet it comes nearest to Bouvardia quaternifolia, DC., which, with B. Jaquinii, I am persuaded (from the description) are merely forms of hirtelli. The species varies within wide limits.

Mitracarpium $\dagger$ breviflorum, Gray (Pl. Wright. 2, p. 68)-Annual, 4-8' high, unbranched, slightly four-angled, nearly smooth; leaves 10-14" long, 2-4" wide, having between their bases a dense capitulum of small, white flowers; bracts bristle-like, very delicate; calyx-teeth unequal, the two longer twice as long as the calyx-tube, subulate, the two shorter very small; terminal liead of flowers, according to Dr. Gray, is subtended by four leaves.Sanoita Valley, Arizona (605).

- Bouvardia, Salisb.-Flowers in clusters at the end of the branches. Calyx with 4 slender lobes. Corolla with a long and slender or sonewhat tiumpet-shaped tube and 4 short spreading lobes, valvate in the bud. Anthers 4, almost sessils in the throat. Style 1; stigma of 2 flat lips. Pod small, globular, 2-cel.ed; secds wing-nargined-GruY, in Field, Forest, and Garden Botany.

† MitiacanPICM, Zuccar.-Flowers hermaphrodite, capitato. Calyx-tube turbinate-obotoid, or sub-globose; teeth 4-5. Two often longer than the cthers, sorcetimes with smaller ones between, persistent. Corolla salver- or funnel-shaped, tube often encireled in ide by a hairy ring; lobes of the limb 4, valvate, spreading. Stamens 4, inserted on the throat of the corolla; anthers fixed by tho back. Disk fleshy. Ovary 2, rarely 3-celled. Style with two shortish, linear brauches; amphitropous ovules solitary in the cells. Fruit didymous, membranaceous, opening transversely at or below the middle, the npper part going with the calyx and exposing the seeds, the septa remaining in the other portion. Seerls oblong, globose, with the ventral face flat or 4-lobed; testa membranaccous, alburen dense, fleshy; cotyledons foliaceous.-Erect or prostrate herbs, root frequently perennial, branches 4-angled. Leaves opposite, linear-lanceolate or ovate, the upper ones often the longer, the setose, shcatling stipules connate with the petiole. Flowers in dense heads, minute, white, often intermixcd with bri_t!es.-Bextmay \& HOOKER. 
Galius micropirzlum, Gray (Pl. Wright. 1, p. 80).-Smooth, ascending, ribbed stems, quadrangular, with obtuse angles; four linear-lanceolate leaves in a whorl, $3-5^{\prime \prime}$ long, with distinet mid and marginal nerves, somewhat apiculate; peduncles axillary, one-flowered, or more frequently (in my specimens) proliferous from the involucre; fruit pruinose-Tunks south of Camp Apache, Ariz. (271). A well-marked species.

Galium asperrimum, Gray.-(425), from Mount Graham, Arizona, appears to be a form of this, with the fruit minutely tuberculate.

Galium asperrimus, Gray? (Pl. Fendl. p. 60).-Mount Graham, Arizona, $\complement, 000$ feet altitude (425). Ovary in my specimens minutely tubersulate, rather than hairy. Mature fruit I have not seen. Indeed, I am not sure that the specimen may not prove to be $G$. Aparine, to which it appears closely related. If so, then it must be truly indigenous.

Galium trifidum, L.-San Luis Valley, Colorado $(15,16)$.

Galium boreale, L.Common and variable, in Colorado (17); Utah

\section{VALERIANACEA}

Plectritis congesta, DC.-Nevada

Valeriana dioica, L., var. sylvatica, Watson.-South Park, Colorado, at 10,000 feet (773).

Valeriana edulis, Nutt ( . ciliata, T. \& G.) - Radical or stem leaves may be entire or pinnately parted, or with any degree of division between. Valerian odor is very strong in this species on boiling — South Park (774).

\section{COMPOSIT AE.}

Stevia * Canescens, Benth -Erect, $4-6^{\circ}$ high, glabrous or puberulent below, rather roughly canescent above; leaves linear or oblanceolate, with smaller ones fascicled in their axils, serrate toward the apex, entire and

"Stuvis, Cav.-Flowers of the head all perfect and tubular. Involucre of 5-6 narrow, hard, subequal bracts. Receptacle flat, naked. Corollas equal, regular, slender; limb sometimes rather large, 5-cleft. Stamens appendiculate, obtnse at base. Branches of the style long, slender, and obtuse. Achenia linear, 4-5-angled. Pappus of two kinds, i. e., small scales and bristle-like awns, one or both kinds present in the same flower.-Herbs or erect shrubs, not u: ually much branched. Lnaves opposite, or the upper alternate, often 3-nerved and serrate, or sometimes 3-cleft or entire. Heads irregularly loosely paniculate or in a close corymb. Flowers white or purple, sometines a little longer than the involucre. Achenia suooth or ciliolate on the angles, - Benthas \& Hooker. 
gradually tapering to a petiole below; scales of the involucre rather hard, acute, with distinct midribs, roughly pubescent; pappus of short scales and 4-5 upwardly barbed awns; achenium linear, with five ciliolate angles. Corolla narrowly tubular--Sanoita Valley, Arizona (607). So far as any mere description goes, this plant answers better to S. serrata, Cav. in Prod. v, p. 118, than to canescens. However, as it has been compared for me by Professor Gray, I cannot doubt it is correctly placed under the latter name. 732, from Mount Graham, Arizona, at an altitude of 9,C00 feet, appears to be a distinct species (probably new), with broader, shorter leaves, less attenuated at base, with an expanded tube to the corolla, larger scales in the pappus, and red tips to the pappus awns. Lacking proper means of comparison, I provisionally refer it here.

Eupatorium Berlandieri, DC. (Gray, Bot. Mex. Bound. p. 76, where its affinities are discussed).-Herbaceous, $2^{\circ}$ high, sub-puberulent below, puberulent above; leaves petioled, opposite, ovate or triangular-cordate, crenately serrate, 1-2' long and half as wide; flowers about 20 in a head; pappus not larger than the corolla; achenium very slightly scabrous on the angles; scales of the involucre in two series, acute and ciliolate.-Sanoita Valley, Arizona (606).

Eupatorium PURf UReum, L.-Utah.

Brickellia (Clavigera) longifolia, Watson (Amer. Naturalist, 7, 301) - "Very slender, with spreading branches, glabrous, with a slight scabrousness; leares linear, acuminate, 2-5 inches long, flat, entire or obscurely sinuate-toothed, rough-margined, 3-nerved, punctulate; flowers on short, slender pedicels, axillary, and in small, loose, terminal clusters; involucre glabrous, $2^{\prime \prime}$ long, the scales acutish or the inner linear ones obtuse or truncate, spreading; achenium 10-striate, slightly and minutely hairy on the angles, nearly a line long; pappus soft, minutely barbulate, but little longer than the achenium.- Southern Nevada. Also collected at Kanab, Southern Utah, by Mrs. E. P. Thomson."-Plate V. Branch, somewhat enlarged. Figure 1. A single head of flowers. 2. A single flower. 3. Style, enlarged about 15 diameters. 4. Receptacle and involucre. 5. Achenium and pappus. $b^{\circ}$ A bristle of the pappus, enlarged about 20 
diameters. Except where otherwise specified, the figures are enlarged about 10 diameters.

Brickellia betonicefolia, Gray (Pl. Wright. 2, 72) -Erect, covered with spreading, jointed hairs; leaves sessile, ovate, 3-nerved, crenate, hairy and somewhat glandular above and below, becoming smaller toward the top and gradually reduced to mere bracts; 2-4 heads of flowers on peduncles from the axils of the upper and opposite leaves; involucre in two or three series, all acute and ribbed, but the inner twice longer than the outer; pappus rough and achenium silky villose-Arizona, Prof. Oscar Loew.

Brickellia Wrighti, Gray (Pl. Wright. 2, 72).-Sub-shrubby, $4^{\circ}$ high, much branched, glabrous or puberulent below, sub-scabrous and glandular above; leaves petioled, cordate, irregularly crenately toothed; veins prominent below; inflorescence thyrsoid-paniculate, each branch from the axil of a small leaf or branch; pedicels distinctly glandular hairy; heads about 15 -flowered; corollas slender and styles much exserted; achenia hirto-puberulent; pappus roughish; scales of the involucre in about three series, purple-tipped, plainly nerved, obtuse-Black River, south of Camp Apache, Ariz., at 5,000 feet elevation (793).

Brickellia Califoricica, Gray.-Nevada and Útah.

Brickellia grandiflora, Nutt.-Colorado (422, 423).

Liatris scariosa, Willd-Dwarfed specimens from Trout Creek, Colorado (458).

Xanthocephal.um* Gymospenmoides, Benth. \& Hook. (Gutierrezia? gymnospermoides, Gray, Pl. Wright. 2, 79.)-Smooth, ereet, herbaceous, 2-3 ${ }^{\circ}$ high; leaves lanceolate, entire or nearly so, tapering into a petiole, slightly glistening with a gummy exudation, $2-3^{\prime}$ long, and about $6^{\prime \prime}$ wide; heads in a compound corymb; rays many, rather small, without pappus; diskflowers with a minute crown-like pappus of chaff, which in the central

-Xastuocepinalus, Willd.-Heads beterogamous; flowers of the ray pistillate, uumerous, about 1-seriate; disk-flowers perfect, fertile. Involucre lemispherical or broadly campanulate; bracts in many series, imbicated, coriaceons, with appressed or spreadiug tips, the outer ones smaller. Receptaclo plane, foveolate. Pistillate corolla ligulate, sob-entire, spreading, elongated or small; perfect flowe s regular, tubular; limb somewhat enlarged, 5-cleft at the apex. Anthers entire, obtnse at base. Style of the perfect flowers with flattened branches; appendages iriangular or lanceolate. Achenia hardly compressed, smooth or striate. Pappus of minute chaff, coroniform or none.-Herbs or shrubs, with erect or ascending stemn, often branching. Heads niddle or large sized, solitary, on the end of the branches or loosely corymbose. Flowens all yellow. Achenia smouth.-Bestusv \& Ilooker. 
flowers is sometimes prodiced into about six small, rigid bristles; involucre glutinous, with spreading tips; receptable flattish, alveolate. Separated from Gutierrezia by Bentham and Hooker on account of its numerous rays and coroniform pappus.-San Pedro River, Arizona (551), and old Camp Crittenden, Arizona (66 6 ).

Gutierrezia Euthamis, T. \& G.- $(411,4 ! 2,414,415)$.410 is the same, verging toward microcephala; from Colorado, Arizona, New Mexico. Number 378 of the Sutton Hayes Collection appears in my herbarium under name of G. microcephala, and doubtless correctly, but it is so near some forms obtained by the Expedition that pass for G. Euthamia that one may well doubt the propriety of keeping them distinct.

Grindelia squarrosa, Dunal--Colorado (Loew, 100). Utah.

Grindelia microcephala, DC. (G. inuloides, Willd, var. microcephala, Gray, Bot. Mex. Bound, p. 81.)-Stems erect, smooth, branching somewhat; leaves thick, rigid, oblong, entire or slightly toothed toward the apex. Amplexicaule or sessile, inflorescence cymose(?); pappus (in my specimen) none in the ray-flower, and of only two awns in the disk; scales of the involucre almost always destitute of subulate tips, thick, oblong, and acute in several series, the inner of which are the larger; achenia flattened, four-angled, with corky angles, smooth.-Southern Arizona (7!96).

НетекотнесA* scabra, DC.-Erect, much branching, somewhat rough, with long, spreading hairs arising from glandular bases; upper leaves rough, veiny, sessile or clasping, oblong or ovate, entire or toothed; lower ones petioled; inflorescence in a spreading panicle; achenia of the ray smooth, of the disk densely covered with appressed silky hairs.-Moist ground near Camp Lowell, Ariz. (703).

Chrysopsis villosa, Nutt.-From among the multitude of forms under

* Heterothkca, Cass.-Heads leter gemcue, raciate, with the rays in 1-2 series and pistillate; flowers of the disk perfect. Involuere hemisplerical or broadly campanulate; bracts imbricated in many series, narrow margin subscarious, exterior ones swaller. Receptacle flat, alveolate, fimbrillate. Femalo flowers wi:h ligulate, sub-entire corollas. Perfect flowers with regular, tubular corollas, somewhat enlarged above and 5-cleft. Anthers ob use, entire, or a little emarginate at base. Branches cf the styles of the perfect flowers flat, with long, narrow, or sometimes triangular and short appendages. Achenia flat, with a thickish margin and an obtuse apex. Pappus of the ray none, of the disk of au outer series of very short bristles, and an inner series of loug scabrous bristles.-Erect, rongh berbs, witb alternate and often dentate leaves. Heads ratber large, loosely paniculate or in a clope corymb. Flowers all jellow. Achevia glabrons or silky villous. Pappus rusty-colored.-Bentram \& Hooker. 
this species, I can recognize var. hispida, Gray, which is best marked, with its leaves lanceolate and acute, or spatulate, oblong and obtuse, from $\frac{3}{4}-1^{\prime}$ long; plant hispid, with short, stiffish, and more or less dense hairs. (555, 46 1 , from Colorado, 792 from Arizona, and an unnumbered one collected by Loew in New Mexico; var. foliosa, Watson, more leafy, with leaves obovatespatulate, $1^{\prime}$ long, and more or less canescent, running into $C^{2}$. canescens, $\mathrm{T}$. \& G. (791, 182, from Arizona, and 552 from Colorado). Canescent form (i24) from Southern Arizona is well marked.)

Var. Rutteni.-Stem erect, densely leafy; leaves 1-1 $\frac{1}{2}$ long, lanceolate, acute, densely covered with long, white, silky hairs; leaves gradually reduced to bracts under the involucre; ray-flowers $\frac{3^{\prime}}{4}$ long, $1-1 \frac{1}{2}{ }^{\prime \prime}$ wide.-Sanoita Valley, Arizona (662). This may be reduced to $C$. villosa var. canescens, which is apparently its nearest ally, jet it is quite different from any specimens of the latter that I have in my collection.

Aplopappus* Macronema, Gray (Proc. Amer. Acad. 6, p. 542).-Tivin Lakes, Colorado, 9-10,000 feet altitude (451).

"Aplopappus cervinus, Watson ( mer. Naturalist, 7, p. 301).-Low ( 6 inches high), suffruticose, resinous-scabrous, the short herbaceous stems leafy to the top; leaves oblong-lanceolate, 4-6" long, shortly cuspidate, attenuate to the base, entire, sub-scabrous, 3-nerved; heads 3-4" long, in corymbs of 3-5, terminating the branches; outer involucral scales linear, acuminate, with setaceous, spreading lips, the inner chartaceous, acutish, with scarious, lacerated margins, erect, nearly equalling the pappus; rays few, narrow, and but little exceeding the disk; style exserted; achenia linear, pubescent.-Nearest to A. suffruticosus, Gray, Antelope Cañon." Utah.-IVatson, l. c.-Plate VI. 1. Branch, natural size 2. Inner involucral scale. 3. Outer involucral scale. 4. Disk-flower. 5. Style and stigma. 6. Anther. All except the branch enlarged.

Aplopappus Fremontir, Gray (Jour. Bost. Nat. Hist. Soc. v. 5).Glabrous, $1^{\circ}$ high; corymbosely branched above, with the leafy branches

*APLoparic8, Cass.-Meads several- to many-flowired, beterogamons with fertile rays, or homo gamons aod destitute of rays. Involucre imbricated, in 2-several rows; seales with mostly acute and oftev somewhat spreading tips. Receptacle flat or nearly 80, foveolato or alveolute. Appendages of the st.yle usnally elongated-subulate. Acbenia variable in sbape. Pappus simple, of copions, unę̧nal, rigid, enpillars bristles, which nre more or less rougb.-Herbs or nuder-8brubs, with jellow flowers, and pappus tawny or reddish, not often white.-(After Gray, Fl. Cal. vol. 1, p. 310.) 
terminated by a rather large head; leaves oblong to linear-lanceolate, acute, sessile, coriaceous; scales of the involucre oblong, mucronate, in several series (inner ones much the longest), more or less ciliate; ray-flowers variable in length, but in my specimens one-third longer than the tarny pappus of the disk.-Loew, near Pueblo, Colo. (15).

Aplopappus Parryi, Gray.-Twin Lakes, Colorado (471).

Aploppapus Nuttallin, T. \& G.-6' high, from a woody base, more or less densely covered with a close, rather ashy pubescence; leaves obovate or lanceolate cuneate, thickish, serrate, the teeth tipped with long bristles; head smallish ( $3^{\prime \prime}$ in diameter); rays none; disk-flowers 20-25, harlly as long as the fulvous pappus; scales of the involucre in about three series, thickish, rather obtuse, and with scarious margins.-Loew, Arizona (17 a).

Aplopappus gracin Is, Gray.-10-18' high; many wiry stems from the same root, sparsely covered throughout with long and delicate white hairs; small lower leaves pinnatifid, lobes rounded; upper leaves entire, narrowly linear, 3-6" long; heads $3-5^{\prime \prime}$ in diameter; scales of the involucre in several series, acute and somewhat mucronate or hairy tipped, half as long as the rays; receptacle deeply fimbrillate; bristles of the pappus distinctly unequal.-Sanoita Valley and Camp Apache, Southern Arizona (596); and var. denudatus, Torr., also from Arizona.

Aplopappus spinulosus, DC.-Much branched, from a woody base, softly puberulent or canescent; leaves pinnately parted, 6-18" long, rather rigid; lobes again often variously divided, and tipped with a delicate bristle; involucre $4-6^{\prime \prime}$ in diameter; scales in about four series, lanceolate, slightly mucronate or bristle-pointed; tawny pappus of the disk about equal to the flowers; rays 6-9" long.-San Luis Valley, Colorado (470); and Santa Fé, N. Mex. (24).

Aplopappus lanceolatus, T. \& G.-San Luis Valley, Colorado (474, 485). This form is in some features intermediate between $A$. Vaseyi and $A$. tenuicaulis, D. C. Eaton, and probably likely, according to Prof. Asa Gray, to destroy the latter species. See Watson's Botany of the 40th Parallel, p. 160.

Aplopappits inuloides, T. \& G.-Low, and much branched, from a short stem, tomentose throughout or sometimes nearly glabrous; lower 
leaves linear-lanceolate or lanceolate, tapering (usually) into long petioles, entire or irregularly and sharply serrulate, acute; upper leaves few, smaller and sessile; heads large, generally solitary; involucre mostly woolly (sometimes beconing glabrous when old); scales in about three series, linceolate and rather obtuse; rays many and very variable in size and shape (in most of my specimens the rays are sterile); disk-flowers 2" long; achenia fusiform, villous; pappus light brown.-Union Creek Pass, Colorado, at 10,000 to 11,000 feet $(472,579)$.

Aplopappus laricifolius, Gray (Fl. Wright. 2, p. 80).-Shrubby, low, resinous-dotted, much branched; branchlets short, leafy; leaves numerous, linear or nearly so, with a slight thickening upward, 5-8" long; heads corymbose, terminating the branchlets; scales of the involucre in two series, acutish, with a brown midrib and scarious margin; rays $3-5$ and 4 " long; disk-flowers 8-12; pappus coft, unequal and somew hat club-shaped; achenia distinetly villous.

This plant, from its general habit, clearly justifies Bentham and Hooker in retaining it with others under the old genus Ericameria, Nutt. Professor Gray, however, has indicated (Proc. Amer. Acad. viii, p. 635) that to do this involves at least two other genera in confusion.-Mount Turnbull, Arizona, Prof. Oscar Loew.

Bigelovia* Wrightir, Gray.-Woody at base, smooth or roughish, several thin stems rising from the base a foot or more high; leaves linear, obtuse, somewhat falcate, glistening from a resinous exudation, $6-1 \gamma^{\prime \prime}$ long; heads rather small; scales of the involucre coriaceous, obtuse and regularly imbricated in about four rows; disk-flowers $8-15$, longer than the inner scales of the involucre; style-appendages shorter than the stigmatic part; achenia turbinate and hairy.-Arizona. Also the rougher var. hirtelloscabra, Gray, with smaller and less resinous leaves (Linosyris Wrightii, Gray, Pl. Wright. 1, p. 95).

- Bigelovia, DC.-Heads corjmbose or cymose-clustered, rarely paniculate, 5-30-flowered, homogamons, the flowers being all perfict and with tubular corollas. Ivvolucre imbicated; the scales dry, chartaceons or coriareons, chiefly destitute of foliaceons or berbaceous tips. Receptacle flat, foveolate or alveclate-denticulate, rarely with a cbaff-like projection in the centre. Appendages of the style-branches varying from ovate-lanceolate to subulate or filiform. Akenes narrow, terete or angular, eligbtly if at all ecmpressed. Pappus simple, of copions uncqnal capillary bristles as in Aplopappus, or sufter and more eqnal, fawny at waturity.-Herbs or under-shrubs, with narrow slteruate leavis, aud roostly small heails of yellow flowers, otc."-Gisay, Fl. Cal. p. 314. 
Bigelovia Parryi, Gray.-Woody at base, $1^{\circ}$ high, at first softly tomentose, at length nearly glabrous; leaves linear, 2-3' long, $2^{\prime \prime}$ wide; heads in a narrow thyrse, rather large; scales of the involucre loosely imbricated in about 3 series, acutish, or with the tips sometimes attenuated, about 12-flowered; teeth of the corolla rather large, tube puberulent; appendages of the style subulate or filiform.-Twin Lakes, Colorado, at 9,800 feet (453). (Linosyris Parryi, Gray, in Proc. Acad. Phila. 1863, p. 66.)

Bigelovia Bigelovir, Gray.-Woody at and a little above the base, much branched from below; whole plant somewhat ash-colored; leaves filiform, revolute, more or less recurved and scattering; heads 4-6-flowered, in a raceme or slender panicle; scales of the involucre coriaceous, lanceolate, often acute or acuminate and in 4 or 5 series; pappus quite tawny, as long as the very slender flower; achenia smooth, linear, 4-6-angled, and with a broad epigynous disk; appendages of the style long and filiform, a little roughish under the lens.-Headwaters of the Arkansas in Colorado (454).

Bigelovia graveolens, Gray. (Linosyris graveolens and albicaulis, T. \& G. Fl. 2, p. 234.)-Colorado, New Mexico, Arizona, Nevada, and Utah; also var. albicaulis, Gray, obtained from Nevada.

Bigelovia Douglasir, Gray (Linosyris viscidiflora, T. \& G.), var. serRulata, Gray; also var. tortifolia, Gray.-Twin Lakes, Colorado (413, 447). (478 is a broad-leaved form.)

Solidago Californica, Nutt., var. ?-Stem simple, whole plant more or less densely covered with a short pubescence; leaves thickish, entire, oblong, 1-3' long and 2-9' wide; heads crowded into a dense, contracted panicle; scales of the involucre thickish, obtuse, and the outer puberulent; rays 6-8 (less numerous than the disk-flowers), large (2-3"long); achenia pubescent.

This form (730) from Mount Graham, Arizona, and at an altitude of 9,000 feet, may prove a distinct species; believing, however, that its nearest affinity is as above indicated, I place it here for the present.

Solidago Virga-aurea, Linn., var. humilis, Gray.-(86 of Loew); $(409,404)$, from Colorado, and a specimen without number, collected by Loew from Mogollon Mesa in Arizona, 4,000 to 5,000 feet. Var. Alpina, Bigel. (407), Half-Moon Creek, Colorado, at 12,000 feet altitude.

Solidago Guiradonis, Gray (Proc. Amer. Acad. vi, p. 543).-Nevada. 10 вот 
Solidago pumla, T. \& G.-Stems several, from a woody procumbent caudex, $2-4^{\prime}$ long and leafy, angled, striate and nearly smooth; leaves rigid, mucronate, linear, or linear-lanceolate, 9-18" long; heads few-flowered, clustered in 3 or 4 , and disposed in a small corymb : scales of the involucre in several series, outer ones much shorter, rather acute, thickish; rays short and (like the disk-flowers) 2-4. Scales of the involucre appear (from my single specimen) to vary much in shape, acuteness, and thickness of the keel.-Eastern Arizona, at 6,500 feet, Loew.

Solidago nemoralis, Ait.-Twin Lakes, Colorado (408); also a variety from Nevada, Utah, and San Francisco Mountains, Arizona.

Solidago sparsiflora, Gray (Proc. Amer. Acad. xii, p. 58).—"Virgaurea, Virgata: Scabrous-puberulent; lower leaves unknown, upper ones and floral ones smallish, lanceolate (6-12" long); racemes loosely fewheaded and loosely thyrsoid; scales of the involucre linear, puberulent, at apex rather acute and greenish; ray-flowers about 10, ligules small; disk-flowers 4-5; achenia silky-pubescent-Camp Lowell, Arizona." (706.)

Solidago moluis, Bartl. (S. incana, T. \& G., var. $\beta$. ? ) -This rather remarkable form (782) from Arizona is canescent on the stem, $2-4^{\circ}$ high; leaves decidedly scabrous, tripli-nerved, entire or sharply toothed toward the apex; head medium-sized and densely crowded in a contracted, secund panicle; scales of the involucre lanceolate, acute, and somewhat scarious on the margin, and with a darker midrib; achenia pubescent; branchlets of the panicle and the pedicels densely and softly tomentose.

Solidago Marshalli_-Erect, nearly smooth, or slightly pubescent in lines; leaves linear-lanceolate or lanceolate, entire, sessile, tapering toward either end; glandular dots and veinlets transparent by transmitted light, 1-4' long and 2-7" wide; panicle compound, and with the branchlets strongly secund; heads medium-sized, rays 8 , disk-flowers 9 ; achenia short, cylindrical, hairy; scales of the involucre lanceolate or oblong, obtuse, thickish, and under the lens minutely roughened on the margin; pappus shorter than the disk-flower; bracts minute, almost subulate, about three on each of the slender smoothish pedicels. 
It is evident that this plant is near to $S$. adora, Ait., but it appears to differ in its leaves and in the obtuse scales of the involucre, as well as in the larger number of flowers (of both kinds) in the head, and in the absence of the characteristic odor of odora. I name it in honor of Lieut. Wm. L. Marshall, United States Engineers, for whose assistance in my work I am under many obligations.-Chiricahua Agency, Southern Arizona (530).

Solidago Missouriensis, Nutt.-Twin Lakes, Colorado (405).

Solidago Canadensis, L. (var. ?) - This form has been placed here by Dr. Gray. It is, however, nearly perfectly smooth, or at most only puberulent below and slightly pubescent above; leaves also are barely roughish above and glabrous below.-Twin Lakes, Colorado (406).

Aphanostephus * Ramosissimus, DC.-Stems much branched from a woody base, nearly glabrous, puberulent, or somewhat hispidly pubescent at tip; lower leaves narrowly spatulate or oblanceolate, variously toothed or divided at the apex, closely sessile, 1-2' long, 1-3" wide; upper leaves narrower, more entire and pubescent or hispidly pubescent; heads $3^{\prime \prime}$ in diameter; involucre-scales in two series, oblong, rather acute and pubescent, the apices and margins distinctly scarious; rays 2 -4 " long, narrow, at first a little pinkish and afterward yellowish or white; diskflowers yellow, hardly longer than the scales of the involucre (in my specimens, there is no evident thickening of the tube of the disk-flowers); pappus coroniform, of very short bristles; achenia obscurely angled, manyribbed (most distinctly so on the inner side), and with a few rather long hairs.-My specimens (336) from the Gila River, in Arizona (2,800 feet altitude), show considerable range of variation in shape of leaves, acuteness of involucral scales, and degree of pubescence.

"Aphanostephus, DC.-Heads heterogamous, radiate; ray-flowers fertile; disk-flowers perfect. Involucre hemispherical, the linear or lanceolate bracts imbricated in a few series, their apices and margins scarious [slightly], exterior ones somewhat sborter. Receptacle convex. Rays narrow, spreading and entire; disk-flowers tubular, the limb elongated, slightly enlarged, 5-toothed. Anthers entire and obtuse at the base. Branches of the style in the perfect flowers compressed, terminated by very short, oltuse appendages. Achenia subterete or obtusely 4-5-angled, many-ribbed. Pappus coroniform dentate, sometimes short.-Much branched, erect or ascending, canescently puberulent herbs. Heads solitary on the dilated apices of the branches. Rays white; disk yellow. Achenia smooth.-Bentris \& HOOKER. 
Townsendia* RothrockiI, Gray, $\dagger$ in herb. - Perennial, stemless; leaves narrowly spatulate, narrowed into a petiole as long as the blade, both together $1^{\prime}$ long; blade thickish, entire, smooth; petiole expanded toward its insertion, and with a few silky hairs; heads sessile, $1^{\prime}$ in diameter, obtuse scales of the involucre in 3-4 series, oblong or narrowly oval, purplish, thickish, margins distinctly ciliate, or toward the apex sometimes slightly fimbriate lacerate; rays fertile, blue or purplish, exceeding the disk by one-half, 1-1 $\frac{1}{2}$ " wide, entire or toothed; pappus somewhat united at base, squamellate-subulate, one-fourth as long as the tube, with one or two bristles exceeding the others; disk-flowers yellow, about as long as the rather unequal pappus; achenia rather hairy, oblong, flattened. Heads one or more from the same caudex. Apparently a somewhat variable species, but sufficiently distinct from $T$. sericea, to which it most nearly approaches by the obtuser scales to the involucre, the shorter and broader rays, and the short pappus of the ray-flowers. It will hence be observed that it approaches Nanastrum, though kept distinct by its perennial root.South Park, Colorado, at 13,500 feet (875). (Also either 418 or 417 of the already distributed sets, but from a mixing of labels I cannot determine which.)—Plate VII, A. Natural size. 1 Inner involucral scale. 2. Rayflowers. 3. Ray-style and stigma. 4. Portion of ray-pappus, magnified about 25 diameters. 5. Disk-flower. 6. Cross-section of achenium. 7. Style and stigma of disk-flower. 8. Bristle from ray-pappus. All enlarged about 10 diameters, except where otherwise specified.

Townsendia sericea, Hook.-Resembling the above in general habit, but differing in having silky-canescent and narrower leaves, acute scales to the involucre, longer and narrower rays, and a longer pappus to the ray-flowers.-Colorado (419), at Kit Carson (on the plains), and also a var. with shorter rays and more hairy and narrower leaves at Georgetown, among the mountains.

- Townsendia, Hook.-Heads radiate; rays fertile; disk-flowers perfect or sometimes [both I] infertile. Involucre bemispherical or broadly campanulate, the lanceolate bracts imbricated in a fow series, the exterior smaller, margins scarious. Receptacle plane, naked or finbrillate. Rays louger than the involucre, entire or tootbed; disk-flowers regular, tubular, the limb narrowly campauulate or a little dilated with 5 short teetb. Anthers at base obtuse, entire. Branches of the style in the disk-flowers flattened, with lanceolate appendages. Disk-achenia compressed, those of the ray 3-angled, the scabrous or barbellate pappus rigid, unequal.-Low perennial or annual herbs, more or less canescent.-Rocky Mountain Region between the Saskıtchewan and New Mexico.-Bextias \& Hooker.

t Dr. Grny has indicated T. scapigera, D.C. Eaton, as the nearest relative of this species. 
Townsendia strigosa, Nutt.-Valley of the Upper Arkansas, Colorado $(517,853)$.

Townsendia scapigera, D. C. Eaton (Vol. V of Fortieth Parallel Survey, p. 145 , pl. xvii, figs. $1-7$ ).-Nevada.

Aster tanacetifolius, H. B. K. (Macharanthera tanacetifolia, Nees.)Biennial, erect, $6^{\prime}-2^{\circ}$ high, usually much branched, pubescent or viscid, or sometimes nearly glabrous; leaves once to three times pinnatifid, the divisions bristle-tipped; involucre hemispherical, $3-8^{\prime \prime}$ in diameter; scales imbricated in several series, lanceolate or linear, always acute, and sometimes with very long, tapering, herbaceous tips; rays about 25 , violet, twice as long as the disk-flowers; achenia with two strong marginal ribs, and several on either face, very villous; mature pappus reddish.-Colorado (854, 491, 505, 19). Also from Arizona and New Mexico.

Aster canescens, Pursh. (Macharanthera canescens, Gray; also Eaton in Bot. King.) - Very variable, and obtained by the Expedition from Colorado, Arizona, New Mexico, Nevada, and Utah.

Aster Coloranoensis, Gray. (Proc. Amer. Acad. xi, 76.)-420 and 455 of the Colorado collection, in which it was distributed as Macharanthera canescens. Stems $2-4^{\prime}$ high, several from the same root, each terminated by a single head, tomentose or canescent ; leaves coriaceous, the lowest spatulate, the upper lanceolate or linear, all sharply serrate, having the teeth bristle-pointed; involucre hemispherical, the acute herbaceous-tipped scales narrowly lanceolate, canescent, and in 2-3 series; rays 35-40, large, bright purple; achenia ribbed, turbinate, and densely canescent or villose; pappus rusty-colored.

Prof. T. C. Porter raises the question as to whether this may not be Dieteria pulverulenta, Nutt. I have not access to authentic specimens of this; but there certainly are many strong resemblances from the description in Flora of North America by Torrey and Gray. See vol. 2, p. 101. Unlike the others of the same section, this (Aster Coloradoensis) is perennialPlate VII, B. Natural size. 9. Ray-flower. 10. Ray-flower style and stigma. 11. Disk-flower. 12. Disk-flower style and stigma. 13. Achenium and pappus of disk-flower. About 10 diameters. 
Aster adscendens, Lindl--Twin Lakes, Colorado, at 10,000 feet. (522); also from Utah. Var. ciliatifolius, T. \& G., stems with many linear leaves (1-3' long and 1-3' wide), somewhat ciliate; scales of the involucre ciliate, acutish; upper part of the stems rather hispidly pubescent.-Cottonwood Creek, Colorado (524). The leaves are in the main narrower and the scales of the involucre less acute than in 252 of Hall and Harbour's collection, with which my 509 more nearly compares. Nunber 492 of our Colorado collection is a slender, almost leafless state, with smaller rays and more acute tips to the involucre than the typical var. ciliatifolius. 523 approaches $A$. falcatus, Lindl. Number 525, marked by Dr. Gray as a curious form, is, except for its smooth involucral scales, very much like $A$. integrifolius, Nutt. (No. 6166 of Bolander's California collection), and so like the description of $A$. adscendens, var. Parryi, Eaton, that I am constrained to leave it there, and hence will probably be $A$. adscendens, Lindl. (?) (as considered by Dr. Gray in Fl. Cal. 1, 324); from Colorado. A specimen of adscendens, however, collected by me at the Soda Spring, on Kern River, in California, is like 525 in the involucral scales, but with much narrower leaves. Except this one from California and the one from Utah, all my material is from Colorado, at or above 10,000 feet altitude.

Aster Nuttallii, T. \& G. Fl. 2, p. 126 ; var. Fendleri, Torr. (A. Fendleri, Gray, Pl. Fendl. p. 66).-In the absence of the plant, I subjoin the following original description of Dr. Gray, entire, from Pl. Fendl.: "Span high, with many ascending, rigid, somewhat hispid stems from a subligneous root; branches monocephalous, corymbose-paniculate; leaves small, rigid, entire, linear, coriaceous, sessile, mucronulate, smooth and single-nerved, with the margins hispidly ciliate; the lowest subspathulate, and the upper very short; involucre campanulate, scales in 3 series, linearoblong, glandulose-scabrellate, mucronulate, the exterior herbaceous ones obtuse and lax, the interior a little longer, acute; achenia pubescent." (510.)

Aster falcatus, Lindl.-Valley of the Upper Arkansas, Colorado, and San Francisco Mountains, Arizona (488, 501).

Aster simplex, Willd-Devada.

Aster multiflorus, L., var. $\gamma$. сомmutatus, T. \& G.-Stem slender, unbranched, nearly sessile, $3-4^{\prime \prime}$ in diameter; scales of the involucre 
oblong-spatulate, thickish, roughish-pubescent. Leaves $6^{\prime \prime}$ long and 1-2" wide, with fascicles of smaller ones in their axils-Arizona coll., Oscar Loew. The Expedition has also a variety from Utah, which I have not seen. Aster glacialis, Nutt.-Utah.

Aster elegans, T. \& G., var. Engelmani, D. C. Eaton. (Aster Engelmanni, Gray.)-Utah.

Aster Douglasir, Lindl. ?-San Luis Valley, Colorado (500). Scales of the involucre narrowly lanceolate, very acute, with a narrow chartaceous margin; leaves $2-4^{\prime}$ long, $2-5^{\prime \prime}$ wide, with the margins distinctly hispidly ciliate.

Aster salsuginosus, Richards.- $(486,520,516,504$.$) From Colo-$ rado, and all good representatives of the species. Number 521, however, differs widely in appearance, both in the dried and living states, from the others, and might even by many be regarded as a distinct species compared with 516 and 520 . It is shorter, much more leafy, with the scales of the involucre oblong, obtuse, and almost smooth, except on the ciliate margins; the rays are wider, shorter, and more deep purple, to say nothing of its having a broader and smoother achenium. I do not, however, regard it as even a good variety, for all $(516,520$, and 521) were obtained from a single clump in a cool, shady location at 11,300 feet, on Union Creek Pass, in Colorado.

Aster Pauciflorus, Nutt.-Stem erect, simple, 1-2 ${ }^{\circ}$ high, smooth below, puberulent or viscidly puberulent above; stem-leaves linear, 2-6' long, 1-2" wide, indistinctly 3-nerved; entire margins thickish and smooth, becoming gradually reduced to subulate bracts above; heads few, terminating the branches, $3-5^{\prime \prime}$ in diameter; scales of the involucre in about three series, acutish, viscidly puberulent; rays purple, twice as long as the diskflowers; pappus light-colored, almost in a single series and nearly as long as the disk-flowers.-San Luis Valley, Colorado (508).

Aster spinosus, Benth.-Stem much branched, glabrous, striate, subangular above and terete below; leaves few, scattered, and reduced to subulate scales, 1-3"l long; heads solitary (rarely racemose), terminating the branches; scales of the involucre not longer than the disk, in three series, acute, and with scarious margins; achenia glabrous.-A most peculiarlooking plant extending across the southern part of the continent, from Texas to California; Southern Arizona (769). 
Aster* ericefolus, Rothrock (in Botanical Gazette, Jan., 1877).Willow Spring, Arizona (208); Santa Fé, N. Mex. (14).

Erigeron Canadense, L-Central Arizona (718, 764).

Erigeron compositum, Pursh-Colorado (493); also var. discoideus, Gray, from Utah. Number 496 from Colorado is a form near E. pedatum, Nutt, but still somewhat hirsute, and the leaves and petioles distinctly hispidly ciliate, and the involucre as hairy as the typical E. compositum.

Erigeron grandiflorum, Hook., var. elatius, Gray (Enum. Pl. Parry).-A foot or more high, with several heads; stems leafy almost to the summit; scales of the involucre with extremely delicate tips, and united into a woolly mass.-Mosquito Pass, Colorado (487, 490).

Erigeron ursinum, D. C. Eaton (in vol. V, King's Survey, p. 148).(495.)

Erigeron uniflorum, L., var.-4-10' high, more or less pubescent, a single head terminating the erect, sparsely leaved stem; lower leaves spatulate-oblong, tapering to a hispidly ciliate petiole; stem-leaves oblanceolate, sessile; scales of the involucre somewhat crowded, hairy, and usually with purple, tapering tips; rays about 60, purple, twice as long as the diskflowers (achenia too young); pappus almost uniform and a little shorter

* "Diplopappus Eiricoides, T. \& G.-To save labor to nome others who, like myself, work under the double disad vantage of a rather limited library and an herbarium (rich enough in the later new species) with but few specimens from the original sete made prior to 1862, I put the following in print. From our present standpoint it is evident tbat Diplopappus as formerly noderstood must be partitioned out among other neighboring genera, and of the species that concern ns here, one goes to section ERICAMERIA of Aplopappus, and the other to section ORTHomerts of Aster. In the unavoidable changiug of names a confosion arises under the name above given, i. e., Diplopappus ericoides, there being two plants that bear the name in herbaria and books. The following may in some sense clear up the matter:

Diplopappus ericoides, T. \& G. Eucephalus ericoi- | Diplopappus ericoides, Less. Aplopappus ericoides, des, Nutt. "Inula? ericoides, Torr.! in Ann. Lyc. New York, 2, p. 212. Chrysopsis ericoides, Eatob, Man. Bot."

Now placed in Aster under Sect. ORthomeris. As the name ericoides is preoccupied in this genus I suggest for it Aster ericafolius, which indicates eveu more closely its general habit.

See also Diplopappus ericoides, T. \& G., Vol. V., King's Report; Pl. Wright., p. 78; Pl. Fendl., p. 69 ; Bot. Mex. Bound., p. 78.

The two plants are so different in habit, - the one suggestive of (80 far as arrangement of the foliage goes) Erica, ani the other of Adenostoma fasciculatum, Hook. \& Arn., or of Eriogonum fasciculatum, Benth.- as well as in habitat, that any furtber description is unnccessary."-Botauical Gazette, January, 1877. 
than the disk-flowers.-Alpine summits of Colorado $(515,494)$. Near to Erigeron glandulosum, Porter.

Erigeron armeriefolium, * Turcz. (E. lonchophyllum, Hook. in Bot. King's Exped.) $-4-8$ ' high; many stems from a single root; entire plant hispidly pilose; root-leaves narrowly oblanceolate, tapering into long, slender petioles; stem-leaves sessile, linear; inflorescence corymbose or racemose, with a single head terminating a branch; scales of the involucre lax, hardly in two series, acute, and the purple tips often taper-pointed; achenia cylindrical, hairy; pappus with few or no smaller bristles intermixed; rays very narrow, longer than the involucre.-Twin Lakes, Colorado (527).

Erigeron Bellidiastrum, Nutt.-Like the following, except "in having a simple and wholly deciduous pappus, and its achenium is tipped with a broad and white epigynous disk." See Gray, in Proc. Amer. Acad. vol. viii, 648.-Sierra Blanca, Arizona, at 9,000) feet (811).

Erigeron divergens, T. \& G. (E. Bellidiastrum, Nutt, D. C. Eaton in Bot. King's Exped.) Vid. Gray, l. c.-Camp Grant (383), Arizona, and from the Zuñi Villages, New Mexico (169), where it is probably E. cinereum, Gray, Pl. Fendl. From McArthy's Ranch in New Mexico we have (100) a typical $E$. divergens.

Erigeron flagellare, Gray (Pl. Fendl. p. 68).-Perennial, 6-10' high, many slender stems arising from the same root; whole plant strigulose puberulent; lowest leaves spatulate or oblanceolate, narrowed to a petiole; upper leaves linear, sessile, $4-7^{\prime \prime}$ long; heads terminating the erect branches, which are naked near the summit; scales of the involucre linear, acute, with scarious margins; ligules slender, very numerous, white or slightly rose-colored; pappus in (both ray-and disk-flowers) two series, the exterior short, squamellate, the interior longer.-A well-marked species, readily recognized at sight by its horizontal, flowerless stolons. Apex, Colorado (518), and Santa Fé Creek (25), whence doubtless it was first taken by Mr. Fendler.

Erigeron delphinifolium, Willd. (Polyactidium delphinifolium, DC. Prod. v, 281-282.) - Perennial, with many erect, leafy, slender stems from the same root, hispidly pubescent; lower leaves pinnately parted or 
divided, tapering into a petiole; divisions linear or oblong, or sometimes the upper leaves entire, sessile; stems branching toward the summit, a single head terminating each branch; seales of the involucre in about three series, linear, acute, and with scarious margins; rays white, in about two series, fertile; disk-flowers perfect, in both the short coroniform pappus distinctly marked, with a few longer bristles intermixed; achenium with a distinct epigynous disk, somewhat flattened (sometimes with distinet marginal and facial ribs, as in Macharanthera).-Mount Graham, Arizona, at 9,000 feet altitude (731). Number 500, from Camp Bowie, Ariz., appears to be the canescently hirsute variety alluded to in Botany of Mexican Boundary, p. 78. In my specimen, the leaves are also much more finely divided toward the summit (to say nothing of some difference in the achenia) than in the typical form. I think this might be safely regarded as a distinct species.

Erigeron pumilum, Nutt.-Denver, Colo. (514).

Erigeron macranthum, Nutt.-Mount Graham, Arizona, at 9,000 feet altitude (736); also from Utah.

Erigeron Coulteri, Porter--In absence of sufficient material, I am obliged to quote the following good description of Professor Porter (Fl. Colorado, p. 61): "Stem simple, from a slender root, $6-12$ ' high, bearing a single head, smooth below, pilose-pubescent above, leafy to the top; leaves thinnish, pubescent, with ciliate margins, all more or less serrate-denticulate, mucronate, erect, gradually diminishing in size upward; lower ones oblong-spatulate or elliptical, tapering into a margined, ciliate petiole, upper ones oblong or lanceolate, acute or acuminate, sessile, and partly clasping; head large $1-2^{\prime}$ broad, including the numerous white rays; involucre about $9^{\prime \prime}$ broad, hemispherical, densely pilose, but scarcely woolly; scales lance-linear, with scarious margins, tips elongated, subulate, spreading, glandular; achenia pubescent; bristles of the pappus minutely scabrous, outer ones short and few; alveoli of the receptacle rough with lacerate margins." In my specimen, the plant is almost glabrous throughout, except the scales of the involucre, and the leaves are barely denticulate; flower also was purplish. In my preliminary report, I published this (51.y) as "E. macranthum verging toward grandifforum".-Union Creek Pass, Colorado, at 11,300 feet altitude. 
ERigeron SPECIOSUM, DC.-Stem erect, glabrous or nearly so, 1-2 ${ }^{\circ}$ high, strongly furrowed, branching; entire stem leafy, branched above; radical leaves spatulate, petioled, those of the stem sessile, acuminate, slightly ciliate; infloresence corymbose; scales of the involucre in two or three ser.es, crowded, linear, much attenuated at the tip, hirsute, and with scarious margins; rays over a hundred, narrow, purple; achenia slightly hairy, distinctly ribbed; outer pappus present, but not evident.-Western New Mexico, Loew. As this species would here appear to be much out of its range, it may not be out of place for me to state $I$ have compared the specimen with authentic specimens taken from the Cambridge Botanic Garden, and find them the same throughout.

Erigeron cespitosum, Nutt.-San Francisco Mountains, Arizona, and Utah.

Conyza* Coulteri, Gray.-Softly pubescent and very slightly viscid, erect, somewhat branched at summit, $6^{\prime}-2^{\circ}$ high, leafy to the top; leaves linear or linear-oblong, sessile, somewhat clasping (or the lower spatulate), entire or irregularly pinnatifid or toothed; panicle close and crowded; heads small, $2^{\prime \prime}$ long; scales of the involucre lanceolate, acute, with scarious margins and a green middle.-Mount Graham, Arizona, at 9,000 feet (743), where it is extremely common on the more open grounds, and strikingly suggestive, in habit, of Erigeron Canadense elsewhere.

BaCCHARis $\dagger$ C erulescens, DC.-Shrubby at base, $6-8^{\circ}$ high; branches slender; younger shoots and leaves smooth; leaves lanceolate, acute, irregularly sinuate-dentate, tapering to a short petiole, $3-7^{\prime}$ long and $4-7^{\prime \prime}$ wide; inflorescence in a loose paniculate corymb; each head on a slender pedicel with a small subulate bract at base; scales of involucre ovate, with a

* "Conyza Linn.-Heads many-flowered, heterogamous, but not radiate; the pistillate flowers in mavy series and more numerous than the fertile ones, with only a filiform truncate corolla shorter than the style; the few central flowers tubular and perfect, or some of them infertile. Involucre of narrow numerous scales. Receptacle flat or convex, naked. Style-appendages short. Achenes flattened, usually nerved only on the margins. Pappus as in Erigeron, in ours of simple scanty capillary bristles," etc.GraY, in Fl. Cal. 1, p. 332.

†ACCHaris, Linn.-Homogamous, diœcious. The sterile flowers with a perfect style, but an abortive ovary; style sometimes undivided; corolla tubular and pappus shorter and more tortuous. Fertile flowers pistillate only, corolla filiform and truncate. Achenia terete or somewhat compresued, ribbed. Heads many-flowered; scales of the involucre dry, in several series, the outer ones shorter; receptacle flat or flattish.-Herbaceons or low shrubby plants, with alternate leaves and dull-colored inconspicuous (somew hat conspicuous in B. Wrightii, Gray) flowers. 
delicate scarious margin; fertile flower with the style and stigma projecting one-fourth its length beyond the truncate, filiform corolla, the copious pappus reaching to the tip of the stigmas; achenia narrowly cylindrical, smooth, covered with minute papillæ: sterile flowers with a less copious pappus and the tube dilated upwardly, deeply cleft.-Southern Arizona, at about 5,000 feet altitude $(580,447)$.

Baccharis salicina, T. \& G.-Shrubby at base, erect, 6-8 $8^{\circ}$ high, smooth; leaves lanceolate, usually obtuse, entire or irregularly dentate, tapering to a petiole; inflorescence in a compound corymb; heads sessile or with a very short pedicel; scales of the involucre obtuse, broadly ovate, with scarious sub-fimbrillate margins; fertile flowers having a silky pappus twice as long as the truncate flower and its exserted stigma; achenia smooth, cylindrical, with many ribs; receptacle with distinctly fimbrillate alveoli; sterile flowers having less copious pappus and a rather slender tube; flower deeply cleft.-Southern Arizona and New Mexico (771); also from San Luis Valley, Colorado (456); Nevada.

Bacciraris halimifolia, L-Nevada and Arizona.

Baccharis Wrightil, Gray (Pl. Wright. 1, p. 101)-Herbaceous, glabrous, $1-2^{\circ}$ high, diffusely branched from the base, the branches somewhat flexuose and angular-striate; lower leaves spatulate, $4^{\prime \prime}$ long, upper gradually reduced; fertile flowers with lanceolate acute scales to involucre, the margins of which are scarious and the middle green; pappus tawny, $9^{\prime \prime}$ long; achenia $2^{\prime \prime}$ long, terete, plainly ribbed and with transverse rugosities between the ribs. I have not seen the sterile plant; a good description of it is found where the plant was first described.-Central New Mexico at 6,000 feet altitude (93).

Baccharis Emoryi, Gray (Bot. Mex. Bound, p. 83).-Shrubby, much branched, with the branches sharply ribbed and angular; leaves few, obtuse, linear, 2-7" long; heads small, terminal; scales of the involucre in 4-5 series, the outer ones ovate, obtuse, with finely denticulate scarious margins, the inner ones nearly twice as long, linear and acutish; fertile flower with copious white or light-brown pappus, which is $3-5^{\prime \prime}$ long; achenia less than a line long; sterile flower with tube gradually dilated upward; pappus of a few bristles, some of which are distinctly clavate-Arizona. 
Baccharis Sergiloides, Gray, 1.c.-Much branched and nearly leafless shrub; branchlets green, jointed; older branches brown; leaves oblanceolate or nearly linear, $3-8^{\prime \prime}$ long, or reduced to mere scales; heads panicled; scales ovate, thickish, with a green tip (or sometimes the inner ones linear); achenia few-nerved. The young green branchlets are often more or less covered with a glistening, gumny exudation. $\Lambda \mathrm{s}$ in the preceding ( $B$. Emoryi), the pappus of the sterile flower is clavate, though here it is more copious.

Pluchea camphorata, DC.-Telescope Mountain, Southeastern California.

Tessaria borealis, T. \& G.-Nevada.

Ganaphalium palustre, Nutt.-San Luis Valley, Colorado $(426,428)$.

Gnaphalium Sprengelin, Hook. \& Arn. (G. luteo-album, var. Sprengelii, in vol. v of King's Report.)-Cottonwood, Arizona (356); also from Utah.

Ganaphalium strictum, Gray.-Annual (?), simple or much branched from the root, canescently woolly throughout; leaves linear, $6-18^{\prime \prime}$ long; heads condensed into woolly glomerules, and one in each axil, forming thus an interrupted spike; outer involucral scales obtuse, rather ovate, as long as the disk-flowers, inner longer, narrower, and more acute; achenia oblong, smooth.-San Luis Valley, Colorado $(425,427)$, and a depauperate form from Twin Lakes, Colorado (423)

Antennaria diotca, Gaertn.-Colorado (444, 443, 436); common. The Survey has also the var. rosea from Nevada.

Antennaria Carpathica, R. Br.-South Park, Colorado (208, 433, 434).

Anaphalis* margaritacea, Benth. (Antennaria margaritacea, R. Br.)Collected by Dr Oscar Loew on the White Mountains of Arizona, probably at a considerable altitude.

*Anaphalis, DC.-"Heads discoid, incompletely diœcious; viz. the pistillate with filiform, 2-4toothed corollas very numerous, and a few (or occasionally no) hermaphrodite but sterile flowers, with tubular 5-lobed corollas in the centre; the staminate nearly as in Antenuaria. Involucre campanulate, of many ranks, of mostly snow-white scarious scales. Receptacle flat, naked. Style in the staminate flowers usually 2-cleft merely at the apex. Pappus a single series of capillary bristles, unconnected at base, in the sterile flowers (at least in our species) slightly thickened upwards."-GraY, in Fl. Cal, 1, p. 340 ; see, also, Gray in Proc. Amer. Acad. viii, p. 653. 
Melamipodium* cinereum, DC.-Woody at base, 4-12' high, simple or much branched, covered with a short silky pubescence; leaves numerous, linear or slightly linear-spatulate; rays white (about 8), emarginate, oblong or lanceolate-A common plant in the drier parts of New Mexico and Arizona $(96,327)$.

Berlandiera $\nmid$ Lyrata, Benth-Erect, branching at base; radical leaves lyrate on long petioles; terminal segment much the largest and (as well as the others) irregularly toothed; upper leaves lyrate but sessile; rays $6-8$, orange, with darker veins, emarginate, tomentose outside and especially on the veins. Whole plant is softly tomentose-Covero, N. Mex. (98).

Parthenium incanum, H. B. K.-Suffrutescent and much branched; younger branches and leaves canescently tomentose; leaves clustered, oblong, deeply cleft or pinnate, 5-8-parted; divisions obtuse, 9-15" long and : -6 " wide, ashy color from the dense, short pubescence; inflorescence corymbose-paniculate; involucral scales in two series, outer oblong, inner broadly oval or nearly round and scarious with a ciliate-fringed margin; rays short, ligules obcordate; achenia flattened obovate and with a pappus of two short, persistent awns; disk-flowers shorter than the obovate, hyaline, ciliate-fringed scales which enclose them--Camp Bowie, Southeastern Arizona (453).

Hymenoclea monogyra, T. \& G.-Arizona (778).

Ambrosia psilostachya, DC.-Utah, and $(529,697)$ Arizona.

Ambrosia aPtera, DC-Probably hardly sufficiently distinet from some forms of $A$. trifida, $\mathrm{L}$, but having, however, wingless margins to the petioles.-Southern Arizona $(695,696)$.

- Melampodrum, L.-Rass in a single series, fertile; flowers of the disk with an aljortive style. Involucre double, the onter series of (4-5) broad foliaceous bracts, which are often connate at base, the inner as many as the ray-flowers and enclosing their achenia. Receptacle strongly convex. Chaff thin, deciduous. Achenis (of the fertile flowers) oroid, embraced by the hooded inner scales of the involucre.

† Berlaxdiera, DC.-Many-flowered, ligulate rays pistillate. Disk-flowers with an undivided style. Scales of the involucre in three series, the onter small, oblong or oval, the second set larger and obovate, the inner ones largest, rhomboidal, reticulated, bearing on the inner faces the flat, wingless achenia of the ray-flowers. Pappus of the ray of two minute caducons teeth or short awns. Inner face of the ray-acbenium is mostly corered by the chaff of two sterile flowers. Pappus of the disk reduced to the merest crown or border. 
Franseria* Hookeriana, Nutt-Arizona, New Mexico, and Colorado.

Franseria dumisa, Gray.-Low, much branched, shrubby; leaves pinnatifid, with rounded lobes, or bipinnatifid, cinereous, with a short pubescence; mature involucre puberulent or glabrous; spines flat, more or less involute, long and slender.-Arizona.

Xanthium strumarium, L-Utah.

Zinnia $\nmid$ Grandiflora, Nutt. (fig. iv, Report of Major Emory, 1848).Low, much branched from the base, puberulent; leaves linear or linearlanceolate, connate at base, acute, rather rigid, distinctly 3-nerved; margins ciliate, 5-12" long; paleæ fimbriate; disk orange and rays yellow. In my specimens, the leaves are not always "impressed punctate", and are sometimes distinctly glandular-dotted.-New Mexico, Arizona, and Colorado. Collected by Dr. Loew and Professor Wolf.

Sanvitalia $\ddagger$ Aberti, Gray (Pl. Fendl. p. 87).-Annual, erect, $\gamma^{\prime}-2^{\circ}$ high; stem terete, striate, puberulent, simple or branched; leaves linear or lanceolate, 3-nerved, hispidly scabrous and hispidly ciliate, attenuated into a petiole; heads few-flowered; outer scales of the involucre lanceolate, dry, distinctly nerved and somewhat longer than the ray-achenium; chaff lanceolate, with scarious margins, longer than the disk-flower--Southern Arizona (519). An exceedingly variable plant.

Heliopsis Parvifolia, Gray (Pl. Wright. 2, p. 86).-Erect, smooth or nearly so, simple or branched from the base; leaves petioled, triangular or triangular-hastate, subserrate or sinuate, 12-18" long; peduncles elon-

* Franseria, Cav.- "Heads, flowers, \&c., as in Ambrosia, except that the fertile involucre is armed with more than one rank of prickles or spines, and is 1-4-celled and 1-4-flowered."-GRAY, in FI. Ca!. 1, p. 344 .

†ZrNsia, Linn.-Heads heterogamous, radiate; both ray- and disk-flowers fertile. Involucre campanulate or sub-cylindrical, the dry, broad, obtuse bracts imbricated in several series, the exterior much shorter; rays orbicular, cordate at the base, with an obcompressed acbenium destitute of pappus or with one or two short awns; disk-flowers regular, with a somewhat enlarged tube; anthers entire at base. Achevia angular, with a pappus of short awns produced from the angles; receptacle conical, with many chaffy scales embracing the disk-flowers.

† Sanvitalia, Linn.-Heads heterogamous, radiate, ray-flowers fertile, 1-2 series, disk-flowers perfect and fertile. Involucre bemispherical or broadly campanulate, bracts in $2-3$ series, somewhat unequal, dry or with herbaceous apices, which on 2-4 of the outer scales are ex panded into spreading leaves. Receptacle flat or convex, chaffy, chaff embracing the flowers. Ray-flowers without a tube, as long as the mature achenium, emarginate; achenium triangular, with a short, stont awn produced from each augle. Disk-flowers regular, tubular, but little enlarged upwardly, 5-dentate at the apex; achenia flattened, the outer ones roughened, nearly awnless, and the inner narrowly winged, indistinctly ciliate, and with two incouspicuons awns.-BENTH. \& НоOK, in part. 
gated, naked, and terminated by a single head $1 \frac{1}{2}-2^{\prime \prime}$ in dianeter; involuere with scales in about four series, all distinctly nerved, the outer ovate, obtuse, the inner lanceolate, acute; ligules persistent (fading away into a pale sulphur color), 2-3-toothed at the apex ; achenium (ray) 3-angled, rounded, and papillose on the outer side; disk-flowers narrowly tubular; achenia 4-angled; chaff hardly as long as the flower--Chiricahua Agency, Southern Arizona (536). My specimens are apparently much larger-flowered than those of Mr. Wright, on which the species was founded. They came, however, from near his locality.

Gymolomia * multiflora, Benth. \& Hook. (Heliomeris multiflora, Nutt.)-A very variable plant. Nevada, Arizona, Utah, Colorado (779, 551). See vol. v, King's Report, p. 170.

Rudbeckia laciniata, L-(171 of Loew.) Sangre de Cristo Pass, Colorado.

Rudbeckia columanas, Pursh, var. PUlcherrima. (Lepachys columnaris, T. \& G., B. pulcherrima, Don.)-Erect, simple, or branching from the base, strigose-pubescent; earliest leaves lanceolate and entire; stem-leaves pinnately parted, with linear divisions, petioled; upper ones similar, but sessile ; disk columnar, 9-15" long and $4^{\prime \prime}$ wide; ray-flowers dark purple, reflexed, $6^{\prime \prime}$ long and $4^{\prime \prime}$ wide.-Zuñi Village (159), and also collected by Dr. Oscar Loew in White Mountains of Arizona.

Var. TAGetes. (Lepachys columnaris, var. Tagetes, Gray, Pl. Wright. 1, p. 106.) - Similar to the above except in having small yellow or brown rays and a shorter disk. Arkansas Valley, Colorado (24, Loew); Valley of the Rio Grande, above Albuquerque (85).

Rudbeckia hirta, L. (apparently).-Trout Creek, Colorado (549, 550).

Rudbeckia occidentalis, Nutt.-Utah.

Balsamorhiza sagittata, Nutt.-Northern Nevada and Utah.

- Grmxoroma, H. B. et K.-Heac̀s heterogamous, radiate ; rass 1-seried, neutral ; disk-flowers perfect, fertile. Involucre hemispherical or broadly campanulate; bracts in 2-3 series, exterior herbaceous and a little shorter, interior thinner, all narrow, or rarely with the exterior or interior enlarged. Receptacle convex or conical; chaff concave and embracing the disk-flowers. Ray-flowers ligulate, spreading, entire or dentate. Disk-flowers regular; tube short or with a somewhat dilated base. Anthers entire at base or with two small auricles. Strles of the disk-flowers obtuse or sometines terminated by a short, acute appeudage. Achenia of the ray-flowers uarrow, empty; of disk-flowers sub-compressed, 4-angled, obtuse at apex (in our species destitute of pappus),-Erect, branching herbs,-BExTr. \& Ноок. 
Wyethia amplexicaulis, Nutt-Utah.

Wyethia Arizonica, Gray.-2-3 $3^{\circ}$ igh, roughish hirsute; heads 2-4; leaves broadly lanceolate; upper ones sessile; lower ones petioled, a foot or more long; scales of the involucre oblong or lanceolate, cinereous pubescent, ciliate; ligules 12, 10-14" long; achenia acutely angled, laterally compressed, 1-2- (or the outer ones often 3-4-) awned-Willow Spring, Arizona (222).-Plate IX. Branch, natural size. Figure 1. Section through receptacle showing ray-flower and disk-flower in position, the latter subtended by its chaff; somewhat enlarged. 2. Chaff of disk-flower. 3. Disk-flower. 4. Style and stigma of disk-flower. 5. Mature achenium of disk-flower. 6. Style and stigma of ray-flower. 7. Mature achenium of ray. Except where otherwise specified, all enlarged about 10 diameters.

Viguiera* laxa, DC., var. Brevipes, Gray (Pl. Lindh. 2, 228).-The loosely branching stem herbaceous, strigose-puberulent; leaves with short petioles, ovate or deltoid, plainly reticulated on the under surface, irregularly serrate, scabrous on both surfaces; petioles villose, especially on the upper surface; scales of the involucre in two series, lanceolate, pubescent, and nerved on the back, acute; chaff lanceolate, membranaceous; receptacle convex; achenia flattened and densely covered with an appressed pubescence.-Camp Bowie, Ariz. (501); also collected by Loew in Central Arizona.

Viguiera Reticulata, Watson (Amer. Naturalist, 7, 301).- "Whitetomentose; stems herbaceous; leaves subopposite, coriaceous and rigid, broad-ovate, 1-2 inches long, cordate at base, acute, entire, short-petioled, strongly reticulated beneath; bracts small, lancẻolate; heads 4-5 together, in short close corymbs; involucral scales imbricated in 3-4 or more series, lanceolate, thick, appressed or the tips spreading; rays entire; receptacle shortly conical; chaff acutish; achenia silky pubescent, the pappus-awns subulate at base; scales lacerate."-Telescope Mountain, Southeastern California. Will probably also appear in Nevada and Arizona. Not having access to a specimen of this species, I have availed myself of the above

*VIgUiera, H. B. et K.- "Head, flowers, \&c. as in Helianthus, but usually of smaller size; imbricated involncre less herbaceons; receptacle inclined to be conical; and, especially the pappus less deciduous or even persistent, consisting of 2 or more scarious chaffy scales on each side between the awns." GraY, in Fl. Cal. 1, p. 354.

$11 \mathrm{BOT}$ 
description of Mr. Watson.-Plate IV. Figure 6. A branch, natural size 7. A disk-flower. 8. Chaff of disk-flower. 9. Ray-flower. 10. Section through receptacle. All except the branch enlarged 10-20 diameters.

Helianthus petiolaris, Nutt.-Tall, erect, hispid; leaves scabrous (lower sometimes opposite, upper alternate), ovate or ovate-lanceolate, irregularly serrate-acuminate; petioles long (but variable in length); peduncles terminal; heads large; involucral scales lanceolate or broadly lanceolate, acute; disk-corolla hairy at base; achenia villous; pappus of "two chaffy awns"; rays large, over an inch long.-Southern Arizona, Nevada, and Colorado.

Helianthus annuus, L. (Helianthus lenticularis, Dougl., see Gray, Fl. Cal. 1, p. 353 ; also H. lenticularis, Dougl. vol. v, King's Report, and Preliminary Report of Mr. Watson in Wheeler's Survey, Washington, 1874.)-Utah and Colorado.

Helianthus Nuttalli, T. \& G.-Nevada and San Luis Valley, Colorado, with broader leaves (548).

Helianthus giganteus, L., var. Utahensis, Eaton - Utah.

Helianthella uniflora, T. \& G.-South Park, Colorado (546).

Actinomeris* Wrightir, Gray (Pl. Fendl. p. 85).-Erect, somewhat branching; stems canescently hispid; leaves sessile or slightly decurrent, lower opposite, upper alternate, oblong or lance-ovate, irregularly and strongly serrate, thick, scabrous, and distinctly veined, especially beneath; heads on naked peduncles (6-12' long), medium-sized; scales of the involucre in 2-4 series, with a short stout pubescence, outer ones shorter, oblong and obtuse, inner lanceolate and acute; rays short, entire or slightly toothed (or sometimes none). Achenia of the disk cuneate-oblong, with a distinct wing extending half-way down the achenium on either side,

*Actrnomeris, Nutt--Heads heterogamous, radiate; flowers of the ray neutral and in a single series; disk-flowers hermaphrodite, fertile; heads sometimes, by the deficiency of the rays, homogamons. Involucre bemispherical or campanulate; bracts 2-3-8eried, unequal, short or the outer ones elongated and foliaceous. Receptacle convex or at hength conical, covered with chaff, which embraces the diskflowers. Ray-corollas ligulate, spreading, entire or 2-3-toothed; disk-flowers regular, with a short tube; limb elongated-cylindrieal, 5-cleft at top. Anthers entire at base. Branches of the style in the diskflowers terminated by acute appendages. Achenia laterally compressed, with margins attenuated and distiuctly winged. Pappus usually of two persistent awns,-Scabrous herbs. Leaves opposite or alternate, petioled, sessile, or decurrent. Heads middle-sized, solitary, and with long pednneles or corymbose-paniculate.-BеNтн. \& Ноок. 
and produced above into a short, stout, inflexed awn (on either side). Chaff twice as long as the achenium; margins scarious and somewhat fimbriate or ciliate.-On limestone rocks, Camp Bowie, Ariz. (452). Comparing the above with the original description, it will be discovered that there are some important differences; but as the specimens have been compared by Mr. Watson with the types in Cambridge, I cannot hesitate to assign them here.-Puate VIII. Branches, natural size. 1. Ray-flower. 2. Disk-flower and subtending chaff. 3. Disk-corolla, style protruding. (1, 2 , and 3 magnified about 2 diameters.) 4. Style and stigma (20 diameters). 5. Mature achenium (15 diameters).

Actinomeris longifolia, Gray (Pl. Wright. 2, p. 89).-Stems erect, slender, terete, glabrous; leaves opposite, sub-opposite, or alternate, linearlanceolate, sessile, acute, denticulate or entire, plainly reticulate, scabrous on upper surface and hispidly scabrous beneath; peduncles corymbose, naked, hispid, monocephalous; heads $1-2^{\prime}$ in diameter; involucre with scales in two series, the outer of which are lanceolate and with attenuated tips, the inner are shorter and obtuse, resembling the chaff of the receptacle, which is hardly longer than the mature achenium; achenia oval, distinctly winged to the bottom, awnless or with a single short awn occasionally; ligules yellow, sometimes 2-3-toothed, 6-10" long. Leaves sometimes $8^{\prime}$ long and only $6^{\prime \prime}$ wide.-Sanoita Valley, Southern Arizona, (608), and probably not far from the original locality whence it was taken by Mr. Wright.

Verbesina* encelioides, Benth. \& Hook. (Ximenesia encelioides, Cav., T. \& G. Fl. ii, 359.)-Annual, hoary-pubescent, green and almost smooth, branched from or near the base; leaves triangular-ovate or cordate, or sub-hastate, irregularly sinuate-dentate; upper petioles winged and dilated at base into a lobed auricle; involucre with scales in 2-3 series, the outer lanceolate acute, pubescent, the inner shorter and smoother; rays numerous, cuneate-oblong, 4-7" long, 3-toothed at apex ; achenia of the disk with a wide and strong wing; pappus (disk) of two short, weak awns.-San

* Verbesixa, Linn.--Similar to the preceding genus (Actinomeris), except that the rays are fertilo and the disk-achenia are more distinctly 2-winged and 2-awned. 
Luis Valley, Colorado (421), Southern Arizona (772, 462), and Agua Azul, New Mexico (124). A polymorphic plant.

Verbesina podocephala, Gray (Pl. Wright. 2, p. 92).-Erect, 2-3 ${ }^{\circ}$ high, hispid, branching from a woody base; leaves serrate, sub-sessile or even, rarely slightly decurrent, lanceolate to orbicular, 3-5-nerved, with (beneath) veinlets conspicuously netted, beneath glandular hispid, and veins and veinlets with stiff, long, white hairs; peduncle $4-8^{\prime}$ long, monocephalous; scales of involucre in two series, the five outer ovate, roundish, the ten inner longer, chartaceous, and acute; achenia of ray sharply 3-angled or winged, slightly toothed on the angles, the inner flattish, with two (or by abortion one) stiff awns from the angles; flower $1^{\prime}$ in diameter; rays bright sulphur-yellow, oblong, entire or slightly toothed at the apex.Chiricahua, Ariz. (517).

Coreopsis tinctoria, Nutt.-Ash Creek, Arizona, at 5,000 feet altitude (317).

Coreopsis cardaminefolia, T. \& G.-Erect, smooth, slender, almost unbranched; leaves pinnately parted; exterior involucre small; "achenia winged, broadly oval, sometimes with 2 short, subulate teeth"; rays 3-toothed at the summit, twice as long as the interior involucre-Zuñi Village, Ariz., at 6,700 feet altitude (157).

Thelesperma* Lovgipes, Gray (Pl. Wright. 1, 109).- "Suffrutescent"; glabrous, much branched; branches short and leafy; leaves 3-5-parted; segments linear-filiform; peduncles $1^{\circ}$ long, almost filiform, terminated by a single rayless head; inner series of involucral scales with broad scarious margins; outer series small and obtuse; achenium without pappus (merely a very small crown-like border), slender, terete or nearly so, and tuberculate-rugose on the back; chaff not adhering to the cast-off achenia.-Camp Bowie, Ariz. (451).

- Thelesperma, Less.-Heads heterogamons, radiate; flowers of the ray neutral, in a single series; disk-flowers fertile; beads often homogamous from the rays being absent. Involucre double, broadly campanulate; the inner series of subequal membranaceons scales, which are united more than half-way to the summit; the exterior series of a few small bracts. Receptacle flat with many flat scarions palets which subtend the flowers of the disk. Ray-flowers, when present, ligulate, spreading; disk-flowere regular, limb broadly cylindrical or narrowly campanulate, 4-5-cleft. Anthers obtuse at base and entire; styles of the disk-florvers papillose-puberulent at the apex, terminated by an acute appendlage. Achenia linear or linear-oblong, somewhat obcompressed truncate at the apex and erostrate, with two retrorsely pectinate-ciliate awns or naked. Raye, when present, jellow; disk sometimes purplisb. Achenia smooth or tuberculate-BENTH. \& НоOK. 
Thelesperma gracilis, Gray.-Erect, much branched above, smooth; leaves pinnately 5-7-parted, the divisions linear and somewhat rigid; heads hemispherical, on peduncles $4-6^{\prime}$ long; outer series of involucral scales obtuse or acutish; inner series acutish, with margin slightly, if at all, scarious; rays none. ("Achenia oblong-linear, crowned with two stout subulate persistent spreading retrorsely pectinate-hispid awns."-Porter and Coulter in Fl. Col. p. 72.)-Arizona, Loew.

Cosmos* bipinnatus, Cav., var. Parviflorus, Gray. (Cosmos parvifiorus, H. B. K.)-Annual, erect, 6-12' high, glabrous, leafy ; leaves petioled bipinnately parted; segments narrowly linear or capillary; outer series of involucral scales lanceolate, acuminate, as long as or exceeding the inner, obtuse, and somewhat scarious-margined ones; outer achenia short, and the inner ones somewhat longer-beaked; awns variable in number, 2-4.-Arizona (639) and New Mexico.

Bidens tenuisecta, Gray.-Annual, glabrous, branching from the base, leafy ; leaves bipinnately parted; segments entire (rarely again divided) and lanceolate; scales of the involucre linear, hirsute, especially at base; rays (4-7) hardly exceeding the disk; "achenia attenuate-linear, glabrous subtetragonal"; awns nearly as long as the achenia and very strongly downwardly barbed.-Colorado, in the Arkansas Valley (544).

Bidens feniculifolia, DC.-Tall, branching, glabrous, or with the youngest branches puberulent; leaves 2-3 times pinnately divided; segments entire or sometimes lobed; involucre with the outer scales linear, ciliate, and nearly as long as the inner ones, which are oval, with yellowish, scarious margins; rays large, 5-6, 8" long, oval, deep yellow, with plain, brown veins. Achenia (I have not seen) given by Dr. Gray in Pl. Wright. 2, p. 90, as $2 \frac{1}{2}$ lines long (the "var. acheniis minoribus"), and by DC. Prod. v, p. 603 , as 3-31 lines long, and linear-tetragonal, hardly scabrous at the apex, 2-awned.-Sanoita Valley, Southern Arizona (671).

Bidens heterophylla, Ort.? var.?-Erect, smooth; lower leaves petioled, pinnately "5-7-parted"; segments distant, linear, entire, the terminal

* Cosmos, Cav.-Differs from Thelesperma in the inner series of involucral scales not being connate to or above the middle and the rays being rose- or violet-colored, and from Bidens in the achenia being more or less rostrate at the apex. 
one much longer than the others, $4^{\prime}$ long and $3^{\prime \prime}$ wide; upper leaves sessile. 3 -parted; outer series of involucral scales lanceolate, ciliate, as long as the broally margined inner series. Flowers in my specimen are all too young. Mr. Watson has kindly compared it for me, and pronounces it the same as 1233 of Mr. Wright's collection.

Laphamia Stansburir, Torr.-Utah.

"Laphamia megalocephala, Watson (Amer. Naturalist, 7, 301).Scabrous-pubescent; stems diffusely branched, a foot high ; branches simple; leaves alternate, broadly ovate, 2-3 lines long, smaller upon the branches, entire, very shortly petioled; heads large, 2-3 lines in diameter, terminal and solitary, discoid, many-flowered; achenia compressed, hispid; pappus none.-With nearly the habit of the last. Nevada." I have quoted the description from Mr. Watson. The specimen I have not seen.Plate XI. Figure 1. A branch, natural size. 2. A single flower. 3. Style and stigma. 4. - 5. Stamen. Enlarged about 10 diameters.

Perityle * Emoryi, Torr. (Bot. Mex. Bound. p. 82)._-"Sparsely hirsute as well as glandular: leaves round-cordate or fan-shaped in outline, 5-9cleft and the lobes copiously incised, the upper alternate and less lobed: scales of the involucre rather broad: rays short, white, broadly oval: styleappendages oblong and obtuse: akenes narrowly oblong, hispid-ciliate: awn of the pappus only one, very slender, sparsely barbellate above" (Gray in Fl. Cal. 1, p. 397). I have not seen the species. Arizona.

Riddellia† Cooperi, Gray (Proc. Amer. Acad. vii, p. 358).—"A foot

" "Peritrue, Benth.-Heads many-flowered, with pistillate rays, or occasionally none ; the flowers all fertile. Involucre campanulate, of nearly equal scales, slightly carinate on the back, in a single or donble series. Receptacle flattish or conical, naked. Rays 3-toothed; disk-corollas 4-toothed; the tube glandular. Style-branches tipped with (or insensibly changing into) a short and obtuse or more commonly subulate or filiform, bairy appendage. Akeues oblong, flat (laterally compressed), dark-colored, bordered by a cartilaginons mostly ciliate-bearded margin. Pappus a series of byaline or setiform scales, nsually more or less united into a cup or crown, and commonly a sleuder awn from one or both margins.-Rays white (or sometimes yellow ?): disk-flowers yellow."-GraY, Fl. Cal. 1, p. 396.

†RuDDeluta, Natt.-"Heads several-flowered, with 3 or 4 pistillate rays and 5 to 12 diskflowers, all fertile. Involucre narrow, cylindraceous, of 4 to 10 linear-oblong and coriaceous equal woolly scales, which are connivent but distinct, except at the very base, and a few thiuner or scarious ones within, sometimes a narrow external bract or two. Receptacle flat, naked and smooth. Rays large for the size of the head, very broad, abruptly contracted at the base into a short tube, truncate aud 3-lobed at the end, 5-7-nerved (the nerves converging and uniting in pairs within the lobes), becomiug papery, persisient on the akene. Disk-corollas elongated-cylindraceous, with a very short proper tube. 5-toothed at summit; the teeth glandular. Anthers linear, minutely sagittate, or emarginate at base. 
or two high, tomentose-canescent; somewhat naked with age: leaves narrowly linear, entire, minutely punctate : heads solitary on filiform peduncles terminating the branches: akenes glabrous: pappus of oblong eroselaciniate chaffy scales, about a quarter the length of the glandular disk corolla." Not having the specimen, I have been obliged to quote the above, from Fl. Cal. 1, p. 373. Arizona.

Riddellia tagetina, Nutt-A foot high, floccose-woolly or smoother with age, much branched; leaves sessile, narrowly spatulate or oblanceolate, 8-18" long; heads in clusters on the ends of the branches; scales of the pappus entire, about (or more than) half as long as the tube of the diskflowers; rays somewhat puberulent externally.-Camp Bowie, Ariz. (463), and Alcadonis, N. Mex. (82).

Chenactis Douglasir, Hook. \& Arn.-Colorado, about South Park (481, 482); also from Nevada and Utah.

Chanactis stevioides, Hook. \& Arn.-Independence Valley, Nevado. Hymenopappus luteus, Nutt.-Arizona, Colorado, and New Mexico.

Hymenopappus rlavescens, Gray (Pl. Fendl. p. 97).-Leaves less dissected and divisions larger than in the following variety, in which the flowers are a real yellow.-A somewhat variable species. Colorado.

Hymenopappus canescens, var. cano-tomentosus, Gray (Pl. Wright. 2, p. 94, and Pl. Fendl. p. 97).-Erect, floccose-tomentose; leaves bipinnately parted; segments $3^{\prime \prime}$ long and $\frac{1}{2}{ }^{\prime \prime}$ wide; inflorescence in a cymose panicle; heads $4^{\prime \prime}$ in diameter; scales of the involucre with petaloid and somewhat scarious tips ; chaff of the pappus entire, oval, one-half or one-third as long as the tube of the corolla; achenia turbinate, obscurely 3-5-angled, 15nerved, villose.-Western New Mexico, Loew.

Bahia leucophylla, DC.-Nevada.

Bahia absinthirolia, Benth., var. Dealbata, Gray.-Erect, branching from a sub-ligneous root, canescent-tomentose; leaves oblong, trifid at base, with middle division often toothed toward the apex or entire, linear-lanceolate obtuse; heads, including the rays, $8^{\prime \prime}$ in diameter ; invo-

Style-branches of the disk-flowers short, truncate-capitate at the apex. Akenes narrow, terete or nearly so, obscurely striate or angled, glabrous, or in one species cobwebby-villous. Pappus of 4 to 6 byaline nerveless and pointless chaffy seales.-Low and brancbing woolly herbs, probably ail pereunial; with alternate, spatulate or linear leares, either entire, or the radical ones piunately incised, and coryubose suall heads of golden yellow flowers."-GRaY, Fl. Cal. 1, p. 372. 
lucral scales lanceolate, thin, canescent, acutish; pappus scales oblong, searions, as long as the tube of the disk-flower, with a strong midrib, which does not reach the apex; achenia long-cylindrical or elavate, obscurely angled, pubescent. Entire plant densely covered with a close, white tomentum, which may be readily rubbed off-Camp Grant, Ariz., at 5,300 feet altitude (457).

Hymenothrix * WrightiI, Gray (Pl. Wright. 2, p. 97).-Erect, 2-3ㅇ highl, glial)rous, diffusely branched; lower leaves bi- or tripimately parted, divisions filiform; upper ones entire or trifid, with the divisions entire; involucre loose, inner series broadly hyaline-margined, purple-tipped; pappus of 12-15 scales, the awn of which is as long or nearly as long as the scale portion. Achenia narrowly turbinate, black, densely silky-villous; rays none.-Camp Grant, Ariz. (763).

Hymenothrix Wrslizenis, Gray (Pl. Fendl. p. 102).-Erect, puberulent, branching; lower leaves bipinnately parted, upper ones trifid or entire; lobes linear or linear lanceolate; rays bright sulphur-yellow, three-lobed; disk-flowers merely lobed, yellow ; pappus of 12-15 awns, which are barbellate above and slightly expanded into hyaline wings below; achenia whitish and somewhat silky-villous.-Cottonwood, Arizona, at 4,300 feet altitude (350).

Villanova $\dagger$ chrysanthemoides, Gray (Pl. Wright. 2, p. 96).-Erect,

" Hymenothrix, Gray (PI. Fendl. p. 102),-Heads heterogamons, or in absence of rajs homogamons; rays when present fertile aud in a single series; disk-flowers perfect. Involucre turbinate or narrowly campanulate, the appressed membranaceous bracts in two series, the interior of which have the margins and apices scarious or more or less colored; the exterior are shorter and narrower, and slightly, if at: all, scarious. Receptacle small and naked. Disk-flowers narrowly eampanulate and the limb deeply 5-lobed or 5-cleft. Anthers sagittate at base with small anrioles. Stgles of the disk-flowers with long branches, which are terminated by broad and acute or short subulate appendages. Achenia narrowly turbinate and more or less silky-villons. Pappus of many hyaline, awn-tipped suales.-Erect, diffusely branching herbs, which are smooth or a little pilose. Leaves alternate, once or twice pinnately parted or the upper ones simple. Heads middle-sized, irregularly paniculate or corymbose. Corollas yellow [or purplish].-BЕхтн. \& НоОк.

I VulLaxova, Lagasca.-Heads heterogamons, radiate; ray-and disk-flowers both fertile, or sometimes the innermost flowers sterile. Involucre campanulate, the few broad he rbaceous bracts sub-equal, subtending the ray-flowers, or even almost embracing their achenia. Small receptacle naked. Rayflowers ligulate, the blade small, 3-toothed. Disk-flowers regular, tubular; limb 5-cleft, campanulate. Anthers sagit:ate at base, with small auricles. Styles of disk-flowers haviug a short acute appendage terminating the branches; achenia cuneate-oblong, truncate, attenunted at base, more or less 3-augled, the exterior strongly and the interior slightly compressed upon the back, smootb, naked.-Diffuse, glandular, pubescent herbs. Inferior leaves opposite, sometimes the superior alternate, ternately or pinnately dissec ed or often only few-lobed. Heals small or middle-sized, peduncled, irregularly paniculate or corymbose. Corolla yellow. Achenia smooth.-Bentu. \& Hook. 
simple or branching toward the summit; leaves 1-2-ternately parted, the divisions spatulate or oblanceolate, obtuse, simple or lobed; scales of the involucre equal, acuminate, in 2-3 series; ray-flowers about 15 (disk-flowers many); blade toothed or lobed; tube of the disk-flowers externally glandular-hairy; achenia narrowly turbinate or clavate, black, slightly quadrangular, smooth, ribbed or striate, and longer than the corolla; pappus none-Arizona (812, 609).

Palafoxia linearis, Lag. (vide Botany of Fortieth Parallel, p. 424).Arizona.

Palafoxia Hookeriana, T. \& G. ?, probably var. subradiata, T. \& G.6-12' high, simple or branched; leaves linear or linear-lanceolate, hirsute, 1-1 $\frac{1}{2}$ long; pedicels and flowers viscidly glandular-hairy; scales of involucre lanceolate, acute, sub 2-seried; rays variable, large or small, regularly or irregularly 3-cleft; pappus (ray) reduced to small obtuse scales, half a line long; achenia sub 4-angled, hairy, broadly clavate; disk-flowers deeply 5-parted; tube long and slender, or short and thick; pappus of 5-8 lanceolate or oblong scales, which are nearlyas long as the hairy, clavate achenia.A plant which appears to be variable in almost everything about the flower except the disk-achenia. Deserts of New Mexico, Loew.

Porophyllum* macrocephalum, DC.-Annual, erect, glabrous ; lower leaves linear, upper broadly oval (all petioled and glaucous) and sinuatedentate; marginal glands nearly a line long and half as wide; flowers solitary, terminating the pedicels, which are hollow and dilated above; scales of the involucre linear, $10^{\prime \prime}$ long, with one or two lines of glands $1 \frac{1}{2}$ long and $\frac{1}{4}$ "wide; achenia clavate, hairy; pappus fulvous, rough, with delicate hairs, nearly or quite as long as the slender flower-tube; limb of the flower dark brown.-A striking species, found usually on or near limestone rocks. Sanoita Valley, Arizona, at 4,500 feet altitude (682).

* Porophylum, Vaillant.-Head several- to many-flowered, with all the flowers perfect. Involucre cylindrical or cyliudraceous, of 5 to 10 oblong or linear equal scales in a singleseries. Receptacle small, naked. Corollas with a slender or filiform tube and a narrow 5-cleft limb. Style-branches slender, tipped with a subulate-filiform hispid appendage. Akenes long and slender, nearly terete, striate or angled. Pappus of copious, rather rigid, scabrous, capillary bristles, about the length of the corolla.Herbs glabrous and often glancons; with slender branches terminated by pedunculate heads of yellow, whitish, or purplish flowers, and alternate, or below, opposite leaves; these and the scales of the involucre marked by scattered immersed oil-glands, in the manner of Tagetes, \&c., therefore strong-scented.-GraY, Fl. Cal. 1, p. 398. 
Tagetes* micrantha, Cav.-Annual, smooth, 2-6' high; stem simple or nearly so; leaves opposite, entire and filiform or pinnately parted, and the divisions filiform; flowers terminal; scales of the involucre in a single series somewhat united at base, abruptly truncate and sometimes bristletipped; rays white, 1-3 in a head, 1-2" long, entire or slightly denticulate; disk-flowers about 5; pappus of two rough awns nearly as long as the distinctly striate linear achenia, and of $2-3$ scales half as long as the awns, which they sometimes enclose.-Sanoita Valley, Southern Arizona, on rocky hillsides (616).

Pectis† filipes, Gray.-Annual, much branched; leaves smooth, narrowly linear, 12-18" long, less than $1^{\prime \prime}$ wide, with numerous glands, 2-3 bristles on either side at base; peduncles capillary, more than an inch long; involucre of five lanceolate scales, with more or less scarious margins, frequently gland-bearing; rays exserted half their length, not more in number than the disk-flowers (5); disk-flowers half as long as the rays; achenia linear, hairy ; pappus usually of two stiffish awns, which are somewhat thickened at base and slightly scabrous above, or occasionally reduced to one awn and a crown of minute scales. An exceedingly variable species, which Bentham and Hooker, in Gen. Plant, have assigned to the older $P$. Taliscana, Hook. \& Arn. I can see no warrant for this, if the description in Bot. Beechey be correct. It should, however, be stated that the plant appears there to have been described from imperfect material, and more

"TAGeTES, Linn.-Heads heterogamous, radiate; ray- and disk-flowers both fertile, or beads sometimes homogamous, the rays being absent. Involucre cylindrical, the bracts 1-8eried and more or less anited, rarely a single small exterior bract is present. Receptacle flat, often snall, naked or somewhat alveolate-fimbrillate. Ray-corolla ligulate; disk-flowers perfect and fertile, regular, tubular, the limb often enlarged, 5-cleft. Anthers at base obtuse, entire. Style-branches of the disk-flowers slender, truncate, penicillate or short appendicnlate. Achenia linear, attenuate at base, compressed or angled, bardly striate, with a [somewhat] conspicuous callosity at base. Pappus variable [in our species, mierantha, of 2 awns and 2-3 shorter scales ].-Ereet, branching or diffuse glabrous herbs, with the leaves and involucre Laving distinct, strongly scented glands.-BENTH. \& НоOK.

† Pectis, Lino.-Heads heterogamous, radiate; ray-flowers in a single series and fertile, as the disk-flowers also. Involucre cylindrical or campanulate, the free, equal bracts in a single series. Receptacle small, naked. Rays with a small or narrow blade, spreading, entire or 3-toothed; disk-flowers perfect, the ampliate tube short, equally or unequally 5-cleft. Anthers obtuse, sub-entire at the base. Styles of the disk flowers elougated, slender, somewhat lairy, with very short, obtuse branches. Achenia linear, somewhat angled, delicately striate. Pappus of few or many bristles, nfteuer swaller, fewer or simply reducud to scales in the ray than in the disk, or sometimes consisting entirely of small scales resembling a crown, or with these and the bristles intermixed.-Herbs, the leaves and involucral scales of which often abouud in strong-scented glands. Flowers yellow [in $P$. imberbis purple],-BExth. A. Hook. 
perfect specimens may have enabled those authors to place $\boldsymbol{P}$. filipes under P. Taliscana with certainty. Dr. Gray, Fl. Cal. 1, p. 400, still considers them distinct.-Southern Arizona (539) In one specimen, I find three awns to the disk-flowers, which alternate with three scales, each half as long as the achenium.

Pectis angustifolia, Torr.-Low, much branched, annual, 1-6' high ; leaves slightly connate and bristle-ciliate at base, bearing many oval glands, as also do the scales of the involucre; pappus in both ray-and disk-flowers a mere crown of small and somewhat dentate scales, or in some of the outer flowers of the head of one or two awns, when it is P. fastigiata, Gray (Pl. Fendl. p. 62); achenia a little hairy.-A very much dwarfed form of the species, not over half an inch high, is in the collection, obtained by Dr. Loew, probably from New Mexico. Colorado (467).

Pectis papposa, Gray.-"Annual, glabrous, diffusely much branched, a span to a foot high, 'lemon-scented': leaves elongated-linear (2-3' long, less than a line wide), furnished with very few bristles at base: heads slender-peduncled, scattered or corymbose, about 20-flowered: scales of the involucre 6-8-linear; rays, elongated, linear-oblong: pappus in the ray a scaly crown, in the disk of 15-20 capillary and very unequal barbellate bristles. Pl. Fendl. p. 62." Not having access to satisfactory specimens of the above species, I have been obliged to appropriate the above complete description from Fl. Cal. 1, p. 399.-Obtained by the Expedition in Arizona.

Pectis tenelda, DC.-Low and diffusely branched, smoothish; leaves 1-2' long, nearly a line wide; margins slightly revolute and bearing a few oval glands; rays twice (or nearly so) as long as the scales of the involucre, pappus (ray) a few small scales or rarely with an awn; disk-flowers about 10 , two-thirds as long as the ray; pappus (disk) of about 15 very unequal and strongly upwardly barbed bristles; achenia sub-angled and hairy. My specimens do not at all accord with the description in DC. Prod. vol. v, p. 99 , and I am unable to separate them clearly from the above description of P. papposa. Mr. Watson, however, has kindly compared them at Cambridge for me, and I accept his conclusion.-Camp Bowie, Ariz. (446); also obtained by Dr. Loew from Mount Turnbull, in the same region.

Pectis Longipes, Gray (Pl. Wright. 2, p. 69).-Annual, diffusely 
branched; branches procumbent or ascending, conspicuously angled and striate, smooth; leaves $1-2^{\prime}$ long, half a line wide, the margins copiously provided with roundish, lrown glands, with several long bristle-like hairs at base; peduncles $3-6^{\prime}$ long, with several small scale-like bractlets, filiform; involucral scales linear-lanceolate, glandless or with but a single gland; ray-flowers $7^{\prime \prime}$ long, pappus (ray) of two strong awns; disk-flowers $4^{\prime \prime}$ long, pappus (disk) of many unequal and scabrous bristles; achenia reddish, angled and roughish.-A well-marked species from the Sanoita Valley, Arizona (635).

Pectis rmberbis, Gray (Pl. Wright. 2, p. 70).-Erect, much branched herb, 1-2 ${ }^{\circ}$ high, smooth; leaves scattered, few, gland-dotted, filiform, 2-3' long; inflorescence paniculate-cymose; pedicels bracteolate; involucre scales lanceolate, obtuse, enfolding the ray-achenia; ray-flowers purple (as are also those of the disk and also the involucre scales); blade oval and twice as long as the tube; disk-flowers with the tube short and limb dilated upwardly, very slightly bilabiate, a dark gland on each lobe. Achenia (disk and ray) narrow, hairy; pappus of two small scales, with smaller ones between, and some more or less lacerate. The plant emits a terebinthinate odor, and is almost as naked as though it had no leaves.-Sanoita Valley, Arizona (636).

Pectis prostrata, Cav.-Prostrate, branching herb, puberulent; leaves broadly linear or lanceolate ( $1^{\prime}$ long and $1 \frac{1^{\prime \prime}}{}{ }^{\prime \prime}$ wide), entire, and strongly bristle-ciliate at base; heads sessile and somewhat congested; involucre of five oval scales, which are truncate at top and hyaline on the margins, not embracing the ray-achenia; limb of the ray-corolla less than twice as long as the tube, and both combined shorter than the achenium; pappus (ray) of '2-4 lanceolate, acute, somewhat lacerate scales, which are half as long as the hairy achenium; disk-flowers almost cylindrical, and not longer than the five lanceolate, hyaline, and very acute scales of the pappus. Achenia narrow and hairy (slmost hairy-tufted at the apex). The dark glands are scattered throughout the entire blade of the leaf--Dry open plains of Southern Arizona (722).

Helenium autumale; L.-Utah.

Helenium Hoopesit, Gray.-Sierra Blanca, Arizona, at 11,500 feet 
altitude (808). This plant was found blooming higher and later than any other species in Arizona. From the summit of Mount Graham, at 9,000 feet, we have the variety "canescens, pube lanulosa decidua indutum" (Gray), some heads of which have the rays almost entirely wanting. (404.) For a recent arrangement of the genus by Professor Gray, see Proc. Amer. Acad. ix, p. 202 et seq.

Gaillardia aristata, Pursh.-Perennial, $6^{\prime}-2^{\circ}$ high, pubescent (unbranched?); lower leaves linear-lanceolate, obspatulate or pinnatifid, on long-margined petioles, upper ones sessile and usually entire; heads $2-4^{\prime}$ in diameter; rays $1^{\prime}$ or more long, usually entire, yellow; pappus of the ray-flowers somewhat shorter than that of the disk; tube of the diskflowers short, limb cylindrical, glandular-hairy above, and with the lobes bristle-tipped; scaly pappus lanceolate, one-quarter as long as the limb, midrib produced into an awn nearly as long as the disk-flower; achenia slightly hairy; bristles of the receptacle stout, 3-4 times as long as the achenia, thickened at the base-Colorado, in South Park (483).

Gaillardia pulchella, Fougeroux.-Erect, branching, smooth; lower leaves petioled, lanceolate-spatulate, upper ones sessile, broadly lanceolate or oblong; peduncles $4-6^{\prime}$ long; scales of the involucre in two series (the inner shorter), tips much attenuated; rays orange-colored, cuneate, deeply three-lobed; disk-flower lobes purple, glandular-hairy, drawn out into a bristle tip; pappus (disk) with the scales broadly oblong and the midrib as long as the flowers; awns of the receptacle thickened and hardened at base, four times as long as the achenium, which is densely covered with ferrvginous hair (or, as expressed by Torrey and Gray, "involuerate with a viilous ferruginous tuft"). This and the above species often closely resemble one another in the flowers. Indeed, in a specimen from the Laramie Mountains, named by Dr. Gray G. aristata, I find the hairy achenium much more like that of $G$. pulchella (which, from the unbranched stem and pinnatifid leaves), it can hardly be -Cottonwood, Arizona (345).

Actinella acaulis, Nutt.-South Park, Colorado, at 12,000 feet elevation (457).

Actinella argentea, Gray (Pl. Fendl. p. 100).-Stem at base, short, thick, woody, and branched almost as in A. acaulis and leafy; above slender, 
with a few leaves, and terminating in a leafless peduncle 2-4 inches long; lower leaves 3-nerved, spatulate, tapering into a petiole, upper leaves sessile and spatulate, all (as also the stem and involucre) densely silky-pubescent; involucral scales thickish and lanceolate, in 2-3 series, and not longer than the disk-flowers; rays about 15 , cuneate, 3-lobed, nearly 6 "l long; hyaline scales of the pappus broadly ovate, short-awned, glistening; achenia hairy, cuneate-This beautiful little species was obtained from Santa Fé, N. Mex. (5), where it was first detected by Mr. Fendler in 1847.

Actinella Richardsonir, Nutt--South Park, Colorado (484); also from Western New Mexico, Loew.

ACtinelua Grandiflora, T. \& G.-Several erect branches, 6-12' high, from the short stem; entire plant more or less densely covered with a long, loose wool; lower leaves pinnately or sometimes bipinnately parted, the divisions linear; petioles margined with dilated and sheathing bases; involucre densely woolly; scales linear, acute, about as long as the hemispherical disk; head (including the rays) $1 \frac{1}{2}-2 \frac{1}{2}$ in diameter; rays oblong or cuneate, 6-12" long. Apex somewhat truncate, 3-toothed or lobed; disk-flower lobes rather short and obtuse, glandular-hairy; achenia roughish-hairy, with from 6-8 thin, lanceolate, acute pappus-scales.-In Colorado, the most striking plant blooming at an altitude of 12,000 feet (578).

Actinella scaposa, Nutt, var. linearis, Nutt.-Perennial, villous or cinereous-pubescent; scapes numerous, from a much-branched caudex; leaves many, narrowly linear, $2-4^{\prime}$ long and hardly a line wide, glandulardotted petioles expanded into sheathing bases; scapes 4-12' long, terminating in a single head, which, with the rays, is $18^{\prime \prime}$ across; scales of the involucre in two series, oblong, obtuse and quite villous; rays oval or euneate, oblong, 3-toothed, the tube hairy; achenia pyriform, hairy, of five oblong or oval scales, with or without short awns; disk-flowers with almost no tube. and an upwardly dilated, gland-dotted limb, the lobes obtuse, short, and glandular-hairy; achenia as in the ray, except that the pappus is conspicu ously tipped with a bristle-like awn.-Covero, N. Mex. (104).

Achillea Millefolium, L.-Nevada, Utah, Colorado, and Arizona, in the pine region of the White Mountains. 
Leucampyx * Newberryi, Gray (Porter and Coulter in Fl. Colorado, p. 77).-Herbaceous, erect, $1-2^{\circ}$ high, at first closely covered with a loose, fine wool, but becoming almost glabrous later; radical and lower stem-leaves petioled (the bases of the petioles are dilated and somewhat sheathing), bipinnately parted, the divisions linear, obtuse, and entire; upper leaves linear, entire, or remotely toothed; head (including rays) $2-2 \frac{1}{2}$ in diameter; scales of the involucre very woolly and somewhat exceeding the disk ; rayflowers yellow, fading into a "cream-color"; limb oblong or oval, and sometimes toothed at the apex; disk-flowers yellow; achenia black.Western New Mexico, at 6,500 feet altitude, Loew. This rare plant was also obtained in 1872 by Professor Porter at the "Soda Springs, 35 miles northwest of Cañon City", and a good description of it furnished in the Flora of Colorado-Plate XII. Natural size. Fig. 1. Vertical section through the receptacle, showing ray- and disk-flowers; also involucral scale and embracing chaff. 2. Single involucral scale. 3. Ray-flower. 4. Chaff of the receptacle. 5. Disk-flower. 6. Style and stigma. All except the branch enlarged about 7 diameters.

Baileya multiradiata, Gray (Pl. Fendl. p. 105).-More or less densely floccose-woolly, usually but little branched at the base; leaves once or twice pinnatifid; peduncles $4-12^{\prime}$ long, and terminated by a large head $1_{2}^{1}-2^{\prime}$ (including rays) across; rays yellow, very many, in two ranks, cuneate-oblong, somewhat sharply 3-toothed, $\frac{y^{\prime}}{2}$ long-Camp Bowie, Ariz. (495), and El Rito, N. Mex. (97). The Expedition has it also from Nevada.

Dr. Gray (PI. Fendl. p. 106) remarks of B. pleniradiata, "that the style branches exhibit a more or less distinct central mucronation, or slight cone; in the others [species] they are absolutely truncate." I find in the specimens of pleniradiata from Southern Utah, collected by Dr. Parry, that this

"Leucampyx, Gray.-Heads heteroganous, radiate; rays in one series, and, as also the diskflowers, fertile. Disk-flowers perfect. Involucre broadly hemispherical; bracts $2-3$ series, imbricated, broadly scarious at the apex. Receptacle somewhat convex, chaff membranaceons-hyaline, partly including the achenia. Tube of the ray-flowers slender; limb broad 3-toothed or 3-cleft. Disk-flowers tubular, regular; limb campanulate; apex 5-cleft. Anthers obtuse at base, entire. Style-branches of the disk-flowers at the apex short appendiculate, penicillate. Achenia cuneate, incurved, compressed on the back, sub 3-angled, attenuate at base, obtuse at apex ; pappus none.-BeNTH. \& Hook. 
cone is clearly defined, but in some of my Southern forms of what I can only consider as multiradiata that it is also slightly present-i. $e$, the style branches are not absolutely truncate. Whilst in the main I can recognize marked difterences between these two species, the wide range of variation in the rays, size, branching, etc., makes me regard the differences as in the highest sense simply one of degree. It is notewortiny, too, that these two forms appear to come nearer to each other as we go southward.

Artemisia dracunculoides, Pursh.-Twin Lakes, Colorado (530); also obtained from Arizona and Utah.

Artemisia borealis, Pallas.-South Park, Colorado (535, 536). Alpine.

Artemisia canadensis, Michx.-Arizona ; also from Colorado (532).

Artemisia tridentata, Nutt.-Twin Lakes, Colorado (431); also from the New Mexican deserts, Loew.

Artemisla discolor, Dougl--Southern Arizona (753).

Artemisia Ludoviciana, Nutt.-Colorado (529) Arizona, by the earlier explorations of the Survey, and later by Loew from Mount Turnbull. The latter specimen looking toward var. Mexicanu, Gray, having the upper leaves trifid and the margins revolute, and the entire plant (especially younger specimens) tomentose-canescent. From the San Luis Valley, Colorado, we have, in 1873 (539), a much narrower-leaved form (tenuifolia, Gray), which Dr. Gray intimates may be a distinct species.

Var. Douglasiana, D. C. Eaton, is from Southern Arizona (717) and from Utah. Varieties latiloba, Nutt., and latifolia, T. \& G., also from Utah. Artemisia frigida, Willd.-From plains between Denver, Colo., and the foot-hills (469). To this we frequently find Aphyllon fasciculatum, T' $\&$ G., attached; parasitic attachments uniting the rootlets of the two.

Artemisia scopulorum, Gray.-South Park, Colorado (430). Alpine. Arnica cordifolis, Hook.-Clear Creek, Colorado (570).

Arnica alpina, Læestad. (Arnica angustifolia, Vahl.)-Clear Creek, Colorado (569).

Arnica latifolia, Bongard.-Utah.

Arnica longifolia, D. C. Eaton.-Utah.

Arnica foliosa, Nutt.-More than a foot high, erect, simple, tomentose or glandular-pubescent; lower leaves petioled; upper ones sessile, 
slightly connate at base, lanceolate, callous-denticulate, sometimes with $3-5$ distinet ribs; flower, including rays, $18^{\prime \prime}$ in diameter.-Twin Lakes, Colorado (568).

Senecio lugens, Richardson, var. Hookeri, D. C. Eaton. (Senecio lugens, Hook.)-Nevada.

Var. Foliosus, Gray. (S. lugens, var. exaltatus, Eaton in Bot. King's Exped. [fide Gray].) - "Hoary with white wool up to the flowering state, and the stem conspicuously leafy almost to the top" (Gray, Fl. Cal. 1, p. 413.) —South Park and Twin Lakes, Colorado (567, 587).

Senecio triangularis, Hook.-Twin Lakes, Colorado (563); Utah.

Senecio Andinus, Nutt.-Mountains of Colorado near South Park $(564,565)$.

Senecio aureus, L., var. croceus, Gray.-Utah. Var. Borealis, T. \& G.-South Park, Colorado (566). Var. Wernerisefolius, Gray (Proc. Phila. Acad. Nat. Sci. March, 1863, p. 68).-Cæspitose, woolly at first; radical leaves entire, petioled, spatulate-lanceolate, thickish, margins slightly revolute, canescently tomentose beneath, more nearly glabrous above; scape leafless or with one or two bracts.-South Park, Colorado (588), where it appears to be a common form and to hold its characters well.

Senecio Douglasir, DC.-Glabrate form, from San Francisco Mountains, Arizona.

Senecio canus, Hook., var., with narrower, more entire leaves, and longer rays than usual.-South Park, Colorado (559).

Senecio cernuds, Gray (Silliman's Journ. n. s. vol. 33, p. 10).-“Glabrous stem slender, $1 \frac{1}{2}^{\circ}$ high, terminated by a many-headed panicle; leaves lanceolate attenuate at base into a long, margined, subciliate petiole, sparingly sharply toothed or subentire; heads smallish (hardly $6^{\prime \prime}$ ), discoid, nodding on a 1-2-bracteolate pedicel; involucre sub-calyculate, of lax bracteoles; ovary smooth."-Twin Lakes, Colorado (583). For want of the specimen, I have been obliged to quote the original description of Professor Gray.

Senecio longllobus, Benth., var Floccoso-Incana, Gray.- $2^{\circ}$ high, from a woody base, much branched; entire plant more or less white and floccose-canescent; leaves $1-3^{\prime}$ long, entire and narrowly linear or deeply 12 вот 
3-parted or pinnate, with the divisions all linear; inflorescence cymosepaniculate; pedicels few, l)racteolate below; involucre scales with two thick nerves; loosely calyculate beneath the head. A most variable species, already noted by Dr. Gray as being with $S$. spartioides and others inextricably confused.-New Mexico, where it is one of the commonest plants of the dry hill-sides.

Senecio spartioides, T. \& G.-Smooth, suffruticose, much branching; leaves 2-3' long and a line wide, entire or very sparingly toothed; heads corymbose, or corymbose-paniculate; peduncles short, minutely bracteolate, calyculate scales subulate or narrowly lanceolate; involucre cylindrical, scales thin, nerves delicate; achenia silky-caneseent.-Valley of the Upper Arkansas, Colorado (589).

Senecio eremophilus, Richards.-San Luis Valley, Colorado, a narrow-leaved form $(561,562)$; also New Mexico.

Senecio Fremontil, T. \& G.-Colorado; among the mountains at 11,500 feet and upward $(571,572,576)$; contracted above, smooth, striate. Mountains of Colorado, at 12,000 to 13,000 feet altitude $(573,575)$.

Senecio BigeloviI, Gray.-Erect, smooth, branching toward the top; lower leaves ' $5-8$ ' long, less than an inch wide, irregularly sinuate or dentate, the tips of the teeth callous, somewhat falcate, tapering toward the base into a margined petiole; upper leaves sessile and more reduced; heads large, homogamous, nodding, calyculate scales subulate, involucral scales in two series, lanceolate, the inner ones more decidedly scariousmargined than the outer. Achenia oblong, distinctly ribbed, and in some cases under the lens faintly glandular; root a eluster of fleshy fibres.Mount Graham, at and above 9,000 feet (762); also from the Sierra Blanca, Arizona; also var. Monocephalus (Gray?), Twin Lakes, Colorado (587, 674).

Senecio Fendleri, Gray (Pl. Fendl. p. 108).-Twin Lakes, Colorado (557).

Senecio Soldanella, Gray (Proc. Acad. Nat. Sci. Phila. March, 1863, p. 76).-Dwarf, sub-caulescent; root fibrous and fasciculate, glabrous and usually glaucous, monocephalous; lower leaves orbicular, $1 \frac{1}{2}-2^{\prime}$ in diameter, purplish beneath, on petioles $6^{\prime}$ long, which are widely scariousmargined; upper leaves smaller and on shorter petioles, the highest one 
reduced to a small lanceolate bract; head $1^{\prime}$ in diameter, calyculate scales linear, acute; inner scales (involucre proper) broader, acuminate, and somewhat wavy at apex; achenia somewhat cylindrical.

Tetradymia Canescens, DC., var. INermis, Gray.-Eastem Arizona, at 6,500 feet altitude, Loew; also from Southern Colorado (449, 855).

Cnicus Drummondi, T. \& G., (462); and also var. acaulescens, Gray (461). Colorado.

Cnicus undulatus, Gray (Proc. Amer. Acad. x, 42).- South of Camp Apache, at 5,900 feet (293); and Mount Graham, Arizona, at 9,000 feet (742).

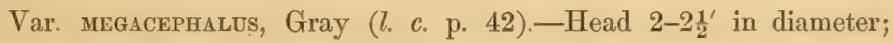
involucral scales broader than in the type of the species and spines (of scales) rather shorter.-Camp Apache, Ariz. (256); also elsewhere from Arizona and Utah.

Cnicus Arizonicus, Gray (l. c. p. 44). (Cirsium undulatum var., Gray, Pl. Wright. 2, p. 101.)-My specimen, a very smooth form, may be briefly described thus:-glabrous, 3-4 ${ }^{\circ}$ high, and loosely branched; leaves pinnatifid, with the divisions tipped with long spines; peduncles short; scales of involucre longer and comparatively narrower from without inward, the outermost distinctly spine-tipped (the innermost acute, but hardly spinetipped); "stigmatic tip to the style barely 4-6 times longer than thick and the node at its base manifest." -Central Arizona (289); Colorado (463).

Cnicus Neo-Mexicanus, Gray (l. c. p. 45). (Cirsium Neo-Mexicanum, Gray, Pl. Wright. 2, p. 101.) $-1-2^{\circ}$ high, covered with a dense, soft, white wool (becoming less so with age); lower leaves petioled, deeply pinnately parted, the lobes tipped with well-marked spines, with margins between spiny-ciliate; upper leaves sessile, less deeply pinnatifid and smaller, becoming gradually reduced to bracts; heads hemispherical, 1-2' in diameter; outer scales of the involucre reflexed, and with tips more strongly spinescent than the inner ones; corolla somewhat irregularly eleft; lobes twice as long as the throat; anthers with a minute spiny tip, longer than each anther is wide.-Santa Fé, N. Mex. (62).

Cnicus Parryi, Gray (l. c. p. 47).-Greenish, or even somewhat glaucous, slightly tomentose; leaves lanceolate, irregularly, deeply dentate, 
the tecth tipped with longer spines than are found on the inter-dental margins; heads many, $1-1 \frac{1}{2}^{\prime}$ in diameter, the subtending bracts spinymargined and tipped; outer involucral scales strongly ciliate-fringed; inner ones less so, except at the tip, which has a small, oblong, ciliate, spine-tipped appendage 1-2" long and half as wide; flowers light yellow.-Twin Lakes, Colorado (460).

Centaurea* Americana, Nutt.-Erect, 4 $4^{\circ}$ smooth; leaves sessile, entire, glabrous or nearly so, but with margins slightly ciliate; heads, including the long purple rays, $4^{\prime}$ in diameter; onter scales of the involucre very short and tipped with a lanceolate, brown, pectinate-ciliate appendage as long, or longer than the scales, the inner series becoming regularly longer and more scarious, the appendage remaining same size as in the outer series; pappus of rigid, similar, roughish bristles.-Chiricahua, Southern Arizona (527).

Pereziat WrightiI, Gray (Pl. Wright. 1, p. 127).—"Smoothish; the leafy herbaceous stem $2^{\circ}$ high, from a perennial root; leaves thin, membranaceous, oblong-ovate, spinulose-denticulate, the larger doubly dentate, sessile and at base often auriculate; compound corymb polycephalous; heads 8-10-flowered, sub-fasciculate, involucre viscid sub-puberulent, scales hardly in 3 series, oblong and rather obtuse; achenia glandular, the soft white pappus of delicate bristles. Well distinguished by its membranaceous leaves and small heads." Not having the plant, I have quoted the original description.-Arizona.

Plirezia nana, Gray (Pl. Fendl. p. 111). - 2-12' high, the singleheaded leafy branches erect from a woolly, creeping root; leaves thickish, strongly reticulate, ovate or a little cuneate at base, sessile, very irregularly toothed, teeth spiny or mucronate-tipped from the produced nerves; heads

" Centaunea, L.-Head $\triangleleft$ mauy-flowered; ray-flowers mostly large and sterile, sometimes wanting; iuvolucre various, imbricated. Receptacle setose. Achenia compressed. Pappus occasionally wantiug or nearly so, but usually composed of scabrons filiform bristles, in one or more series, the inner often smaller and somewhat counivent.-T. \& G.

$\nmid$ Perezi, Lagasca.- "Head several-mauy-flowered; the flowers all perfect. Involucre turbinate or cumpanulate; its scales imbricated, lanceolate or oblong, mostly chartaceous, Receptacle flat aud naked. Corolla with a slender tube and bilabiate limb; the outer lip much longer and 3-toothed; the inner 2-tootbed or 2-cleft. Anthers with long vuked tails at base, and a lanceolate terminal appendage. Akenes elongated-oblong, terete or slightly angled, ofteu obscurely narrowed at apex, commonly glaudular. Pappus of copions scabrous capillary bristles,-Herbs; with alternate and mostly rigid leaves, and solitary or usually paniculate heads of purple or white flowers."-Gray, Fl. Cal. 1, p. 422. 
about 25-flowered, sessile or on very short pedicels, and not higher than the topmost leaf, campanulate; scales of the involucre acute, faintly ciliolate, slightly mucronate, the inner ones much longer, the outer ovate; achenia glandular-puberulent-Arizona.

Crepis glauca, T. \& G. Fruit needed to decide, but probably this.Willow Spring, Arizona (218).

Crepis runcinata, T. \& G.-San Luis Valley, Colorado (664).

Crepis occidentalis, Nutt, var. gracilis, Eaton.-Nevada and Utah. Crepis acuminata, Nutt.-Nevada.

Malacothrix Fendleri, Gray (Pl. Wright. 2, p. 104)._-"Dwarf, glabrous; stems many, diffuse, from a delicate root; younger leaves sparingly arachnoid, radical runcinate-pinnatifid dentate or the lobes cuspidate mucronate, the cauline few, linear, the highest entire; achenia almost cylindrical. Many-ribbed [15-ribbed]; the apex manifestly cupulate, the cupule entire; pappus of a single persistent bristle, with a few smaller caducous ones." I have not the specimen in my collection.-Bowlder, Colo. (466).

Malacothrix sonchoides, T. \& G.-Similar to the above, except that "the entire pappus is deciduous in a ring", the summit of the achenia is not contracted, and of the 15 ribs some are stronger than the others, and the crown-like border of the akene is 15-denticulate.-Nevada and Utah.

Troximon aurantiacum, Hook., var. Parryi, Gray. (Macrorhyncus troximoides, T. \& G.)-Colorado $(66,668)$, Nevada, and Utah. Including here as a mere form (so considered by Dr. Gray), Troximon parviflorum, Nutt., from South Park, Colorado $\left(665,666^{\circ}\right)$.

Pyrrhopappus Rothrocki, Gray (Proc.Amer. Acad.xi,p. 80).--Slender; over a foot high, from a fusiform root, simple or leafy and branching below; one-few-headed; linear leaves entire or toward the base somewhat fringedpinnatifid or dentate; peduncle slender, almost naked; head narrow, about 20-flowered; the few exterior scales of the involucre subulate, appressed; achenia rugulose, above scabrous; mature pappus dirty white--Fisch's Ranch, Southern Arizona, at 5,000 feet altitude (699).-Plate XIV. Natural size. 1. Flower, enlarged about 5 diameters. 2. Style and stigma, about 15 diameters. 3. Young head closed, about 4 diameters. 4 Ache- 
nium and pappus, about 5 diameters. 5. Involucre reflexed, showing markings on convex receptacle, magnified about 4 diameters.

Lactuca Pulchella, DC. (Mulgedium pulchellum, Nutt.)-Cottonwood Creek, Colorado (670).

Sonchus ASPER, Vill.-Utah.

Chetadelpha* Wheeleri, Gray (Watson, Amer. Naturalist, 7, 301). Stems numerous, flexuose, $1^{\circ}$ high; leaves linear-lanceolate, 1-2' long, entire, acute, rather rigid; flowers apparently rose-color; involuere $6^{\prime \prime}$ long; achenia 3-4" long, the brownish pappus exceeding the involucre. With the habit of Lygodesmia juncea, in which genus Bentham and Hooker are disposed to place it.-Southern Nevada.-Plate XV. Natural size. 1. Involucre, enlarged about 4 diameters. 2. A single flower, about 5 diameters. 3. Style and tube of anthers laid open, about 10 diameters. 4. Mature achenium and pappus, 4 diameters. 5. A branching bristle of the pappus, 10 diameters.

Stephanomeria minor, Nutt.-Trout Creek, Colorado (671, 672); also Central Arizona (361, 205).

\section{CAMPANULACE五 (including LoBeliacez).}

Lobelia cardinalis, L., var. Texensis. $\dagger$ ( $L$. Texensis, Raf.)-Flowers as a rule smaller than in our Northern form, and upper anthers more hairy toward the apex; "leaves narrowly lanceolate." Closely resembling $L$. splendens, Willd., as seen in No. 209, Palmer, 1875, but is a coarser, more rigid plant, which may be merely accidental._Camp Bowie, Ariz. (448).

Lobelia gruina, Cav. (ic. 6 , p. 8, t. 511, f. 2)-Perennial, erect, slender, branching toward the top, glabrous or slightly puberulent below; lower leaves lanceolate, obtuse, somewhat puberulent, irregularly crenate-denticulate, $2-3^{\prime}$ long; upper leaves linear, acute, sometimes denticulate; slender flowering branches with the leaves fewer and smaller, narrowly linear

" Chatadelpha, Gray.- "Heads about 5-flowered, ligulate. Involucre cylindrical, of lanceolatelinear, membranaceons, keeled scales, enclosing the achenia, the exterior scales calyculate. Receptacle naked. Ligule short, appareutly rose-color. Achenia linear, truncate at each end, sub-5-angled, somewhat few-striate, with the apex broad and snb-repand. Pappus persistent, brownish of 5 stoat naked awns, to each of which there are 3-6 s maller divisions. Perennial herbs, recembling tle Eulygodesmia." Gray, Proc. Amer. Acad. ix, 218.

† Regarded now by Dr. Gray (Syn. Fl. part 1, p. 3) as belonging to L. splendens, Wilid. 
bracts 5-8" long, hardly exceeding the filiform, sigmoid, or curved pedicels; calyx-tube turbinate, half as long as the acute, ciliolate lobes, sinuses not appendaged; tube of the corolla $3^{\prime \prime}$ long, exceeding the calyx; two inferior anthers hairy-tufted at the apex, and the others pubescent on the back Flowers violet-blue-Sierra Blanca, Arizona, at 7,000 feet (797), and also collected by Dr. Loew on Quevelono Fork, Arizona.

Mr. Watson has kindly compared this for me with specimens in the Cambridge Herbarium, and I cannot doubt his conclusion, but I am bound to say the plant poorly accords with the description given in DC. Prod. 7, 373. See Fl. California, 1, p. 619, for the description of Palmerella debilis, var. serrata, Gray, a new and interesting genus of this order, and Plate XVI of this volume for its figure.

Specularia Perfoliata, A. DC. (Dysmicodon perfoliatum, Nutt.)-Ash Creek, Arizona (314), at 5,000 feet.

Campanula rotundifolis, L.-Mount Graham, Arizona, at 9,250 feet (414); Colorado, Grant Post Office (752).

Campanula uniflora, L.-Grant Post Office, Colorado (751).

Campanula Langsdorfiana, $†$ Fisch - Differing from $C$. uniflora, L., in having an "obconic ovary"; calyx glabrous and the "lobes serrulate on the margins". The flower, too, is larger, i. e., " 1 ' in diameter."

\section{ERICACEA.}

Vaccinium caspitosum, Michx-_South Park, Colorado (741).

Arbutus* Menziesir, Pursh.-Leaves oval, serrulate, pale beneath and bright green above; racemes dense, minutely tomentose; corolla almost globular, white; berries dry, orange-colored, with surface granulate.Santa Rita Mountains, at 7,050 feet altitude.

Arctostaphylos UVa-URSi, Spreng.-Mountain parts of Colorado (742). Said by the late accomplished author of Fl. Bor. Amer. to be used by natives of the Northwest to weaken their tobacco; rather, I should say, to eke it out.

*Akimutus, Tourn,-Corolla gamopetalous; calyx free. Ovary 5-celled, raised on a disk. Stamens 10 , included; anthers opening by pores and having 2 reflexed awns on the back. Placentas thick, on the inner angle of each cell. Berry rongh, several seeds in each cell. The Madroño of the Southwest and Pacific slope, which, toward its southern range, becomes a large tree, but, as seen by me in Southern Arizona, is not over 20 feet high and 2 feet in diameter. Used by the Mexicans in the manufacture of stirrups, ete. Wood hard.

+ Now assigned by Dr. Gray (Syu. Fl. part 1, p. 12) to C. Scheuzeri, Vill., var. heterodoxa, Gras. 
Arctostaphylos tomintosa, Dougl._Shrub, $10^{\circ}$ high; branchlets, younger petioles, and pedicels hispidly pulbescent; leaves oval, thick, (nitire; flowers in short, close racemes, white, pale red, or red; calyx-lobes ciliate, reflexed after fall of the fruit; fruit pale yellowish-red, hairy when young (not warty), several-seeded. One of the several shrubs known as manzanita (or little apple) by the natives. The berries of this are used to form a cooling acid drink.-Mount Graham, Arizona, at 7,000 feet.

Arctostaphylos gLAUCA, Lindl - "8-20 feet high, much branched"; leaves rigidly coriaceous, oblong to round, glaucous, sometimes slightly cordate; flowers flesh-colored; pedicels glandular-hairy, slender; fruit large, enclosing a 5 -celled stone $6^{\prime \prime}$ in diameter. Leaves twisting on their petioles become vertical._Nevada and Utah. feet (739).

Prrola secunda, L.-Shady ravines at Twin Lakes, Colorado, 10,500

Pyrola minor, L-Alpine ravines, Colorado, at 10,500 feet (740).

Pyrola rotundifolia, L., var. uliginosa, Gray.-Twin Lakes, Colorado, at 9,500 feet (738).

Moneses uniflora, Gray.-Twin Lakes, Colorado (743).

Pterospora Andromedea, Nutt-Mount Graham, Arizona, at 9,000 feet (413).

\section{PRIMULACEA.}

Primula Parryi, Gray.-Mountain ravines, Colorado, at 10-12,000 feet (734).

Primula angustifolia, Tort. (Ann. N. Y. Lye. 1, p. 34, t. 3, fig. 3).Root thick; many fibrous rootlets; radical leaves obtuse, lanceolate to spatulate, entire, $6^{\prime \prime}-2^{\prime}$ long; scape 1-3' high, naked or with a few bracts; calyx-tube cylindrical and with the obtuse, lanceolate, subulate teeth as long as the tube of the purple, sub-campanulate corolla (sometimes a little shorter); corolla 6-9" wide; stamens inserted low down in the tube, the short filaments not more than one-fourth as long as the oblong anthers; stigma broadly clavate or globose.-Colorado (736); alpine.

Primula farinosa, L.-South Park, Colorado (737).

Androsace septentrionalis, L-Colorado (356, 358, 359); Santa Fé (51). Collected also by Dr. Loew in Arizona, but locality not given. 
Dodecatheon Meadia, L., var. latilobum (Graj, Fl. Cal, 1, page 467).-One of the best-marked varieties of this troublesome species, characterized by the "thinner, broader, undulate-toothed leaves, which are suddenly contracted into a petiole, and calyx-lobes about half as long as the capsule".-Colorado, New Mexico (72); Arizona. (Albino form from Mount Graham, at 9,250 feet, 409.) Collected also by Loew in Arizona, but no locality assigned. Nevada.

Steironema lanceolatum, Gray? (Proc. Amer. Acad. xii, 63).-Tonto Basin, Arizona, Dr. Loew. A mere fragment, nearer the above than any other species I am acquainted with.

Steironema ciliatum, Gray, l. c.-Utah.

\section{OLEACE A.}

Menodora* scabra, Gray (Amer. Jour. Sei. 2, 14, 44; Torr., Pacif. R. R. Rep. 7, t. 7).-Branching from a woody base, $6^{\prime}-2^{\circ}$ high, slightly hispidly-puberulent; leaves thickish, entire, margins somewhat revolute, $1-2^{\prime \prime}$ wide and 3-10" long; yellow flowers, in a corymb or panicle, the 7-10 setaceous lobes of the calyx somewhat exceeding the tube of the corolla, and also a little longer than the mature capsule.-Santa Fé, N. Mex. (60), and Southern Arizona (561).

Menodora scoparia, Engelm. (Fl. Cal. 1, p. 471). (M. scabra, var. glabrescens, Gray in Watson's Cat. Pl. Wheeler, 15.)-Differs from the above in being smoother, having ordinarily only $5-6$ lobes to the calyx, and these not longer than the tube of the corolla-Arizona.

Fraxinus viridis, Michx.-Arizona.

Fraxinus anomala, Torr.-Arizona.

Fraxinds coriacea, Watson, Amer. Nat. 7, 302.-"Leaflets 1-2 pairs, coriaceous, obovate or oblong, $1-2^{\prime}$ long, truncate or rounded at the apex

"Menodora, H. B. K.- "Calyx with a short and turbinate tube, and 5-14 narrow lobes from its truncate border. Corolla campanulate, funnel form or almost rotate, mostly 5-lobed; the lobes imbricated in the bud. Stamens 2, sometimes 3, on the tabe of the corolla : anthers oblong or linear. Style slender; stigma obtuse or somewhat 2-lobed. Capsule didymous, mostiy 2-parted, membranaceous at maturity, circumcissile, the upper part of each lobe falling off as a lid leaving the scarions membranaceons base. Seeds 2 (or rarely fewer in each cell), ascending, large and with a fleshy, or when dry a spongy outer coat, destitute of albumen.-Low and undershrubby or nearly herbaceous plants; with sessile leaves, not rarely alternate and terminal, mostly somewhat cymose flowers, which are rather showy."-Fl. Cal. 1, p. 471. 
or acutish, attenuate or abruptly contracted at base, sparingly toothed, mostly rather long petiolulate, glabrous, or, with the petioles, pubescent when young: fruit $\mathbf{1}^{\prime}$ long, terete at base, widening into an oblong, obtuse wing, calyx persistent.-Ash Meadows, Nevada, and also collected by Dr. Bigrelow on the Mexican Boundary Survey, at Devil's Run Cañon, but not mentioned in the report. A stem of twelve year's' growth, $1 \frac{1}{2}$ inches in diameter, has a smooth grayish brown bark."-Not having access to specimen, I have taken the above from Mr. Watson in Cat. Pl. Wheeler, p. 15. Species reduced by Dr. Gray in Syn. Fl. N. Am. p. 74, to a variety of the following.-PLATE XXII.

Fraxinus pistaciefolia, Torr., forma tomentosa.-Tomentose, leaflets 5 , almost sessile, lanceolate, irregularly serrate, tomentose, especially beneath; samara $1^{\prime}$ long, seminiferous portion terete, $1^{\prime \prime}$ in diameter, $6^{\prime \prime}$ long, equalling the narrow, lanceolate wing. Very variable in shape and hairiness of the leaves, so much so that, in describing it a second time in the Botany of Whipple's Expedition, Dr. Torrey changed the name from $F$. velutina, as it appeared in Emory's report, to the present name-Ash Creek, Arizona, at 5,000 feet altitude (302). Grows to be 20 feet high, with a diameter of 18 inches.

Forestiera* Neo-Mexicana, Gray, Proc. Amer. Acad. xii, 63.Thickish leaves, lanceolate to oblong-spatulate, acute or obtuse, usually irregularly serrate; (staminate flowers not seen,) pistillate flowers in fascicles of from 4-7; immature drupe oval, blue and glaucous; young seed longitudinally wrinkled. $\Lambda$ much branching shrub, 8 feet high.-New Mexico (108).

\section{APOCYNACE A.}

Apocynum androsamifolium, L.-Twin Lakes, Colorado (45).

Afocynum cannabinum, L-Deer Spring, Arizona (191).

"Fonestuera, Poir-Flowers diœcions or polygamous. Calyx, when present, small, unequally 5-6cleft. Corolla none, or rarely 2-3 petals. Stameus 2-4, with shortish filanents; anthers ovate, snbextrorsely dehiscing. Ovary 2-celled; style delicate, stigma thickened or 2-clef ; ovales two in either cell, suspended from the apex of the c.ll. Drupes ovoid or subglobose. Endocarp coriaceous or thin. Seeds 1-2, pendulous; tests membranaceous; albumen fleshy; cotyledons flat, short radicle superior.Smooth or hairy shrubs. Leaves opposite, entiro or serrulate, deciduons, often fascicled in the axils. Flowers small, very like those of Fraxinus, section Fraxinasler; appearing before the leaves from the nodes of the brauches, fascicled or short racemose.-BЕлтнам \& Hoокег. 
Macrosiphonia* brachysiphon, Gray. (Echites brachysiphon, Torr. Bot. Mex. Bound. 158, 43.)-Low, branching from a woody base; branches puberulent; leaves opposite, entire or wavy, lanceolate to oval, usually acute; flowers yellowish-white, $1 \frac{1}{2}-2^{\prime}$ long; throat somewhat exceeding the cylindrical tube, $1 \frac{1^{\prime}}{2}$ across the expanded oval lobes; follicles (mature) 3-6' long, 2-3" wide, puberulent; coma rusty-brown, exceeding the seedLimestone soils, Southern Arizona, at 5-6,000 feet altitude $(646,497)$.

\section{ASCLEPIADE $\mathrm{E}$.}

\section{By Dr. George Engetmann.}

Philibertia cynanchoides, Gray, Proc. Amer Acad. 12, 95 . Synops. 87. (Sarcostemma cynanchoides, Decaisne in DC. Prod. 8, 541. S. bilobum, Torr. Bot. Mex. Bound. 160.)—Tall, climbing, glabrous or glabrate; leaves from deeply cordate to sagittate or hastate, abruptly cuspidate or shortacuminate, 1-2 $\frac{1}{2}^{\prime}$ long; peduncle 15-25-flowered; slender pedicels much longer than the flowers; corolla whitish, nearly half an inch wide; lobes acutish, somewhat ciliate, crowns separated by a very short column.Cienega, near Tueson, Ariz. (566), Rothrock, 1874, and to Western Texas.

Philibertia linearis, var. Heterophylla, Gray, ib. (Sarcostemma heterophyllum, Engelm. Bot. Mex. Bound. 161.)—Glabrous or upward pubescent; leaves 1-2' long, 1-2' wide, some tapering into a petiole, some with a rounded, others with a dilated or auriculate-cordate base; corolla $6^{\prime \prime}$ wide, yellowish, purplish, or whitish, lobes ovate, erowns contiguous.-

"Macrosipmonia, Muell. (Arg.).-Calyx 5-cleft, with many small glauds inside the base; lobes narrow. Tube of the corolla long, cylindrical; throat short, campanulate or sometimes broader and longer than the tube; no scales. Corolla-lobes 5, broad, often erisped. Stamens attached to the highest part of the tube, anthere conniving aroned the stigma and attached to it by a little below the middle; anthercells produced into blunt appendages below. Scales of the disk 5, of which 3 are free and 2 mited. Ovary of two distinet carpels; style filiform; stigma thickened coriaceous, 5 -ribbed, with the base produced into 5 reflexed lobes, acutely and somewhat 2-lobed apiculate; ovules numerous in either carpel. Follicles straight, terete, continuous or sub-torulose. Seeds oblong, crowned with a long (and at length deciduous) coma. Albumen thickish; cotyledons oblong; radicle short.-Undershrubs, erect, simple or branched. Leaves opposite or whorled, with the margin often undulate-crisped. Flowers in a terninal raceme or at length pseudo-axillary, few or solitary, on very short pedicels, white, yellow, or scarlet.BenthaM \& HOOKER.

†Philibertia, H. B. K.-Corolla rotate, deeply 5-parted; crown double, the exterior or membranaceons ring adnate to the base of the corolla, the interior of 5 (in ours tumid, hoodlike) scales adnate to the base of the very short column; pollinia suspended; follicles smooth, acuminate--Perennial, more or less twining herbs.-(Sarcostemma, H. B. K. Bot. Mex. Bound, etc., not R. Br.)-Benth. \& Ноок. Gen. 2, 750. Gray, Proe. Amer. Acad. 12, 95. 
Water-hole near Tueson, Ariz., Rothrock, 1874 (700). From Western Texas to Southem California and into Mexico.

AsclepiodorA* Decumbers, Gray, Proc. Amer. Acad. 12, 66. (Anantherit decumbens, Nutt, A Acerates decumbens, Decatisne, Watson, Bot. King.)Santa F'e, N. MEx. (283), Rothrock, 1874. From $\Lambda$ rkansas to Texas, New Mexico, and Utah.

Asclepias tuberosa, L. - Willow Spring, Arizona (200), Rothrock, 1874. Exactly like the common form of the States. Perhaps the most western locality of this beautiful species.

Asclepias speciosa, Torr. Ann. Lye. N. Y. 2, 218; Watson, l. c. 282.-Willow Spring, Arizona (249), Rothrock, 1874.

Ascleptas involucrata, Engelm. Bot. Mex. Bound. 163; Gray, Syn. 94-Minutely pubescent when young, at last glabrate; several weak, spreading stems from a stout root less than a span long; leaves opposite or alternate, linceolate-linear, tapering, on short petioles, the broader ones with a roundish, the others with a tapering base, the uppermost involucrating the mostly solitary, sessile, or short-peduncled umbel, and commonly overtopping it; flowers greenish with punple; ovate hoods rather longer than the anthers, the short incurved horn slightly exserted from about their middle; pods ovate, acuminate, smooth, pubescent-Algodones, N. Mex. (78), Rothrock, 1874; also in Arizona and adjacent Mexico.

Asclepias verticillata, L., var. subverticillata, Gray, Proc. Am. Acad. 12, 71; Syn. 97.-Taller and stouter than the usual form, with leaves $3-5$ l' long, opposite or ternate; peduncles alternate all along the stem, many times longer than the pedicels; flowers rather larger than those of the ordinary form.-Algodones, N. Mex. (77), Rothrock, 1874. Very similar to Fendler's No. 694 from the same region. It approaches nearer to $A$. Mexicana than to any of our varieties, but is readily distinguished by the scattered (not subterminal) umbels, the flat leaves, with slightly revolute margins, ete. The roots of all the forms of verticillata are fascicled, the

Asclefiodora, Gray, Proc. Amer. Acad. 12, C6; Synops. 88. (Anantherix, in part, Nutt. ; Aoerates, in part, Decaisne and others.)-Corolla rotate-8preading, afterwards closed; hoods inserted over the whole (short) column, spreading and assurgent, sac-shaped, upward 2-celled by a salient crest. Antherwings corneous, narrowed at base, angulate above the middle; pollinia dependent.-Stout, low, perennial herbs, with usually scattered leaves and large greouish flowers in subterminal umbels. 
lower part of the rootstock decaying, the remaining part throws out annually numerous strong fibres. The root of $A$. Mexicana ought to be compared with it.

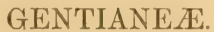

Br Dr. George Engelmann.

Erythrea Calycosa, Buckley; Gray, Synops. 113.-Simple or branching from an annual or biennial base; erect stems quadrangular-winged; leaves linear-lanceolate (about $1^{\prime}$ long), lower ones broader, as long or longer than the internodes; panicle rather contracted, loose-flowered; pedicels as long as or longer (or the upper ones shorter) than the large flowers (8-10" in diameter, rose-colored, with yellow centre); calyx about the length of the flower-tube; lobes of corolla oblong, acutish, often denticulate, scarcely shorter than their tube; seeds small, $0.3-0.4^{\mathrm{mm}}$ long.

In the Gila Valley, Rothrock, 1874 (325), and southeastward into Mexico, Gregg, etc.-Stems 1-1 $\frac{1}{2}^{\circ}$ high, the tallest of our species; leaves 1-1 $\frac{1}{2}$ long, distinguished by its large bi- or tri-colored flowers with acutish lobes. E. venusta, Gray, with which it has been confounded, is a smaller plant with larger deeper-colored flowers, broader obtuse corolla-lobes, and usually longer anthers and larger seeds.-The anthers of the different species of Erythrea are of different shape and size, from orbicular and oval to oblong and linear and $\frac{1}{2}-4$ or $5^{\mathrm{mm}}$ in length; all become at last spirally twisted after they have shed their pollen, the longer more conspicuously so, the shorter much less. The stigmas of this genus have often been misunderstood, probably because mostly observed in dried and pressed specimens. They are never capitate or funnel-shaped, but always bilobed. Before maturity, they remain elosed, and only after the anthers have shed their pollen do both halves separate and spread out, just as the Gentians behave. In the form of the stigma, I find valuable characters for grouping of the species, and especially for the distinction of the American ones from those of the Old World. The stigmas of the former are flabelliform and broader than long; those of the latter are orbicular-ovate or oblong to linear; shortest in E. spicata and linearifolia, and longest in major, where they are twice as long as wide, and in maritima, in which the length is 3 or 4 times 
as great as the width. E. Australis from Australia, as well as Cicendia from Lurope, have stigmas like the American species, but $E$. Chilensis (at least a specimen collected by Ochsenius in Valdivia, which I refer to that species) diflers from all the others in having elongated, cuneate, emarginate stigmas.

The seeds of Erythroea are identical with those of a large group of Gentianea, which comprise perhaps all of Grisebach's Chironiece and Chlorea, being very numerous and very small, from $\frac{1}{5}$ to scarcely more than $\frac{1}{2}^{\mathrm{mm}}$ in the longer diameter, and, when fully mature, globose or oval, with their surface farose-reticulate.

The North American genera belonging to this group may be arranged thus :

1. Stamens inserted in the tube: Erythræa. Eustoma.

2. Stamens inserted in the throat: Sabbatia. Microcala.

Chlora, Chironia, and Sebea of the Old World also belong here.

My investigations have convinced me that the genus Cicendia, or at least its typical and original species, C. pusilla, is nothing but a reduced form of Erythraa, distinguished from it only by its small oval anthers, less than $0.5^{\mathrm{mm}}$ in length, too short to twist much, but still, when drying, sometimes twisting a little. Its stigma is by no means capitate, but regularly bi-lamellate, and, much like that of the American species, triangular-flabellate, and broader than long. The flowers are 4-parted, which often occurs in genuine species of Erythrea; seeds $0.4^{\mathrm{mm}}$ long, large for the size of the plant. It will have to bear the name Erythrcea pusilla.

Erythrea Douglasil, Gray, Fl. Calif. 1, 480; Syn. 113.-Slender, a span to a foot high, loosely and paniculately branched, usually sparseflowered; leaves from oblong to linear, acutish; flowers on strict, slender pedicels, $4-5^{\prime \prime}$ wide; lobes of the pale pink corolla obtuse, much shorter than the tube; anthers usually only $1^{\mathrm{mm}}$ long, style short, stigma about $1^{\mathrm{mm}}$ wide; seeds sub-globose, $0.4^{\mathrm{mm}}$ in diameter-Arizona, Utah, and northwestward to Oregon. This plant has been confounded by Mr. Watson with his $E$. Nuttallii, which, however, is a smaller and more leafy plant, with larger flowers and much larger seeds $\left(0.65^{\mathrm{mm}}\right.$ long), but much smaller stigmas. 
Gentiana* humilis, Stev. Griseb. in DC. Prod. 9, 106. Engelm. Trans. Acad. St. Louis, 2, pl. 9, figs. 1-5. Gray, Syn. 120.-Biennial, with large, broadly oval, rosulate, white-margined basal leaves, and few or many ascending stems of a pale yellowish-green; cauline leaves small, linearoblong; flowers single, terminal; corolla greenish or whitish, 4-6" long, tubular, with acute lobes, and short, notched folds; anthers oval, introrse; capsule clavate-obovate, on a long stipe, usually much exceeding the corolla; seeds oblong.

Wet, grassy spots in the higher Rocky Mountains; also in Asia. The long, protruding capsules (trumpet-shaped when open), together with its pale, sickly look, give the little plant a very curious appearance.

Gentiana prostrata, Hænke; Griseb. l. c. Engelm. l. c. figs. 9-14. Gray, Syn. 120.-Annual, small, weak, 1-2' high, with horizontal or decumbent branches; leaves only $2-3^{\prime \prime}$ long, ovate, green with narrow white margins; flowers azure-blue, 4-parted, terminal on the branches, 5-6" long (or in luxuriant specimens sometimes larger); lobes ovate-lanceolate; appendages half as long, similar or sometimes notched; anthers oval,

* The presence or absence of folds or plaits between the lobes of the corolla and the mode of attachment of the anthers to the flament separate the Gentians into two large and very natural sections, already recognized by old authors: Gentianella (Bor kbausen), Gray, has a corolla without folds and the anthers versatile; Pneumonanthe (Necker), Gray, has a corolla with folds between the lobes and fixed anthers. It will not be useless to explain the term ver satile in respect to anthers, as many seern to misunderstand it, so that they speak of versatile anthers as accidental and unconnected with a physiological process. The fact is that in Gentianella the anthers are introrse in the bud and after it first opens; but as soon as the flower is fully expanded (generally toward the midd le of the day) the anthers gradually assume a horizontal position (the notched base raised and turned toward the as yet immature and closed stigma), open the cells upward, and begin to shed their pollen. Toward evening, the now effete anther is turned over backward, and on the next morniug we find it hanging on the back of the filament, the notched lower end turned up and the empty cells directed outward. Thus in about twelve hours it has described $d n$ almost complete circle. In my figures of Gentians in the Transactions of the Academy of Saint Lonis, vol. 2, pl. 7, 8, 9, and 11, versatile anthers are erroneously represented as turning indiscriminately outward or inward. This is a mistake, as the above account of the living action of the anthers shows. In the figures of $G$. humilis and prostrata, pl. 9, the anthers are also figured as vereatile in that unbatural manner, while in these species they are constantly erect and introrse, as well before opening as when effete.

In Pneumonanthe the anthers remain fixed in two forms. In one section, comprising mostly smaller plants, with smaller flowers (G. prostrata, verna, Altaica, humilis, utriculosa, etc.), they are introrse. In another section, the true perennial large-flowered Pneumonanthes, to which we must add also an annual, G. Douglasiana, and the European $G$. cruciata, they are extrorse. In the genera Halenia, Pleurogyne, Swertia, and Frasera, all represented by plants collected in these expeditions, we find the same arrangement of versatile anthers as in Gentianella. It therefore seems proper to enumerate, first, the Gentians with fixed anthers, and next those with versatile anthers, and then, joining them, the other genera with similar versatile antheral arrangement. 
introrse; capsule linear-oblong, short-stipitate, enclosed in the corolla; seeds oblong.-Alpine regions of the Rocky Mountains, also in Asia, and rare in Europe, where it is said to have usually 5-parted flowers.

Gentiana frigida, Hrnke. Griseb. l. c. 111. Gray, Syn. 120.-Cespitose stems, 1-5' high, with fibrous roots; leaves linear to spatulate, thickish, pale, 1-3' long, their bases forming a long sheath; calyx half as long as the corolla, with subulate lobes and, frequently, a cleft tube; flowers 1-3, crowded on top, funnel-shaped, $1 \frac{1^{\prime}}{2}$ long, yellowish or greenish-white, spotted with red and brown; lobes broad-triangular, acute; reddish plaits wide, oblique, undulate-crenulate, almost entire; anthers free; seeds broad, narrowly winged, with crested ridges.

Springy places, in the alpine regions of the Rocky Mountains, and in Asia; very rare in Europe.-A very handsome plant in the color of its flowers. Its mode of growth is entirely different from any other of our species. The flowering stems bear in the axils of their lowest leaf-pair, within its long sheath, or breaking through it, leaf-buds which in the succeeding year produce flowering stems, while the base of the old stem withers away. The roots are therefore only of one year's growth, thin and filiform, never thick, as those of most other Pneumonanthes, nor is there a real caudex.

Gentiana Parryi, Engelm. Trans. Acad. St. Louis, 2, 218, pl. 10. Gray, Syn. 121.-Few ascending stems from thick fasciculate roots, about a span high; leaves glaucescent, thickish, about $\mathbf{1}^{\prime}$ long, broadly ovate to oblong-lanceolate, with a sheathing base, especially in the lower ones; the uppermost boat-shaped and keeled, involucrating the single or few clustered flowers, concealing the calyx and often almost equal to the large deep-blue corolla; lobes of calyx linear, short, sometimes almost obliterated, shorter than the campanulate often once- or even twice-cleft tube; corolla $1 \frac{1}{2}$ long; somewhat ventricose, its lobes short, broad, acutish, not much exceeding the narrow deeply 2 -cleft appendages; anthers free; seeds linear-lanceolate, wingless.-Moist grassy places in the alpine and sub-alpine regions of Colorado and Utah.

Gentiana alfinis, Griseb. l.c. 114. Gray, Syn. 122.-Many stems, from a stout rootstock, with thick fasciculate roots, a span to a foot high, 
mostly ascending; leaves from oblong to lanceolate or linear; flowers small for the section, 1-1 $\frac{1^{\prime}}{4}$ long, usually clustered in the axils of the upper leaves, rarely few; bracts lance-linear; calyx-lobes linear, unequal, usually shorter than their sometimes cleft tube; lobes of the blue corolla acute, plaits bifid, anthers unconnected; sessile stigmas lanceolate; seeds narrowly, or sometimes more broadly, winged.

Wet, grassy places in the Rocky Mountains of Colorado and Utah. The numerous thin seeds are borne on the whole inner surface of the capsule, which thus not only has the function of a placenta, but really seems to be nothing but a thin, membranaceous expansion of the placentæ themselves, forming a free sac within the capsule, which originates from the commissures of the carpels, and remains attached to them only, and is at last otherwise entirely unconnected with the walls of the capsule. It is probable that all the Pneumonanthes with ovules from the entire inner surface of the capsule have this structure, and that in the others the ordinary arrangement of commissural placentæ prevails.

Gentiana serrata, Gun. Fl. Norveg. 10. Gray, Synops. 117. (G. detonsa, Rottb. Fries, Gray's Manual ed. 5th, 387.)-Low, simple specimens, a few inches high, with single flowers, 1-1 $\frac{1^{\prime}}{2}$ long. Mount Graham, Ariz. (751), at 9,000 feet altitude.

The Norwegian specimens of this plant in my herbarium have much smaller flowers than ours and much smaller seeds. The "scales" which roughen the surface of the seeds prove, when moistened, to be transparent vesicles, single protruding cells of the epidermis. In the Norwegian form, these vesicles are small, oblong, or cylindric; in the American specimens, they are much larger and mostly hemispherical; in the allied $G$. crinita, I find them large and oblong.

Gentiana barbellata, Engelm. Trans. Acad. St. Louis, 2, 216, pl. 11.-Has thus far been found only in the mountains of Colorado, near the timber-line, and is a very distinct species, which can in no way be confounded with serrata or simplex. I have already, in the first account of this species, given the diagnostic characters, and have also stated that it is the only perennial one of the section Crossopetalum in America, somewhat allied 
to the European $G$. ciliata, also a perennial species, which used to be claimed as an annual; barbellata, however, has seeds similar to those of serrata, though much smaller, while ciliata has the winged seeds of simplex, and has an indefinite number of leaves. I have since had the opportunity of studying barbellata in the mountains of Colorado, and found that it possesses a creeping, filiform rhizoma, 2-3 inches below the surface, from which at intervals filiform stems arise. These bear, at their thickened upper end, where they reach the surface of the soil, an undeveloped terminal bud of indefinite growth, and lateral annual flowering stems, the scars of which, enveloped by withered leaf-bases, can be traced sometimes for five or six years back. The vegetation of the plant is accomplished in the following manner.-Each season the terminal bud developes two pairs of basal leaves; from the axil of one of the outer leaves, the single flowering branch originates. Inside of the two leaf-pairs just mentioned, we find a third and a fourth pair undeveloped, about half an inch long, which are to grow into the basal leaves in the following season; and within these the four leaves of the next succeeding season, now only half a line long, are already preformed. The flowering branch, usually 3 or 4 inches high, normally bears one pair of leaves in the middle, and a second involucral pair just below the almost sessile flower; the four sepals are opposite these four leaves, and the four corollalobes alternate with the sepals, and so on. In the axil of one of the third pair of basal leaves preparing for next year, usually alternating with, or sometimes opposite to, the present flowering branch, the bud of next year's flowering apparatus is already four lines long; it shows plainly the two pairs of leaves and the calyx, and, in a very rudimentary state, also the corolla. Thus each year's vegetation exhibits at the flowering period (August and September), on the primary axis, two pairs of leaves for the present, two pairs for the next, and two for the third year, a secondary axis with two leaf-pairs and the flower, and another preformed secondary axis with the rudiments of the same organs for the next year. No other Gentian has, as far as I know, such a typical growth, with the regular preformation of all the organs, but we find the same among other plants in other families, a striking example of which is furnished by our Nelumbium. The regularity in our Gentian is not as absolute as in Nelumbium; for occa- 
sionally two flowering branches are found on the same plant, or three pairs of leaves in place of two, or, very rarely, the upper involucral leaves bear one or even two axillary flowers.

Gentuana Wisluzenit, Engelm. l.c.pl. 7; Gray, Syn. 119.-Annual, erect, a foot or less high, with the habit and the many-flowered thyrsoidpaniculate inflorescence of the next; leaves from lanceolate to ovate, $1^{\prime}$ or less long, with an obtuse or subcordate base; calyx of barely half the length of the tube of the corolla, with very small teeth, its membranaceous tube cleft, and often, in age, dejected; corolla pale purplish, 4- $5^{\prime \prime}$ long, acute lobes finged above the base; capsule linear; seeds subglobose.

White Mountains of Arizona, Rothrock (799), in 1874. This is the only known locality within our flora of this rare plant, which was discovered by Dr. Wislizenus over thirty years ago in the mounwins west of Chihuahua.

Gentiana Amarell., L., var. acura, Hook. f. Gray, Syn. 118. (G. acuta, Michx.).-Annual, 2-20' high; stems wing-angled, usually much branched; lowest leaves obovate, petiolate, upper ones lanceolate sessile; inflorescence paniculate or strictly thyrsoid, with shorter erect or in some forms with elongated patulous peduncles; calyx deeply 5-cleft; herbaceous lobes lance-linear, somewhat unequal, often as long as the tube of the bluish-purple corolla, the lobes of which are oblong, obtusish, beset at base with copious (or in the diminutive alpine form, few) setæ; sessile capsule linear; seeds subglobose.

Grassy places in the mountains of Colorado and northeastward. The true European G. Amarella has usually 4-parted flowers

Halemia Rothrockil, Gray, Proc. Amer. Acad. 11, 84; Syn. 127.Annual, a span or two high, loosely flowered; lower leaves small, spatulate, those of the stem distant, lance-linear, the uppermost closely approaching subverticillate; flowers cymose-subumbellate, on slender peduncles, of cen in sevens, nearly $6^{\prime \prime}$ long, bright yellow, ovate, acute lobes a little longer than the campanulate tube, the five spurs curved, horizontal or ascending, half as long as the corolla; stamens from the throat of the tube; anthers versatile; seeds subglobose-ovate

On Mount Graham, at 9,000 feet altitude; in flower in September, 
Rothrock (733), in 1874. Fvidently allied to three Mexican specries which have also umbelliform cymes; the innermost involucral leaves bear single flowers, the outer ones usually two, and a later secondary flower is borne on a shorter peduncle behind a primary one. This is the only Western species yet discovered.-Plate XXI. Natural size. 1. Flower, 5 diameters. 2. Mature capsule, cross-section, about 5 diameters. 3. Vertical section through flower, about 10 diameters.

Pleurogyne* rotata, Griseb. Gray, Syn. 124. (Swertia rotata, L.).Stems 2-10' high, the smallest ones one-flowered, others thyrsoid-branched, many-flowered; leaves lance-linear; sepals linear, acute, as long as the milk-white $\left(\frac{3}{4}-1^{\prime}\right.$ wide) corolla, acute at both ends

Moist, grassy places in Colorado, sometimes in large patches, and then disappearing again for years. The spreading flowers of this and the next two genera afford the best opportunity of observing the action of the versatile anthers as they slowly turn from the introrse to the horizontal, and then to the extrorsely reversed position, as explained above. The glands on the base of the corolla-lobes are distinct enough, but the surrounding scale is apparently not, as it is ignored by many botanists; I have seen it variable, longer or shorter, but always present; when fully developed, it forms a complete crested or fringed funnel The stigma of this plant is most peculiar, formed as it is directly on the commissure of both carpels

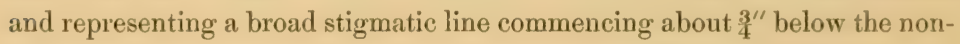
stigmatose apex, running down the sides to the same distance above the base, so that we have here a two-carpellary ovary with two lateral, but without any apical stigma. This line is beset with elongated stigmatic cells or papillæ about $0.1^{\mathrm{mm}}$ long and $\frac{1}{6}$ as wide. At the proper time, numerous pollen-grains are found adhering to the stigma, many of them developing their tubes. The seeds I have been able to examine were not fully matured, but such as they are, they appear oval-oblong, not flattened nor margined, but slightly angular and nearly $0.5^{\mathrm{mm}}$ in the longer diameter

- Plevrogyne, Escbsch.-Erect aunuals of cold or ulpine regions, with opposite leaves, fow or numerous whitish flowers in a fastigiate' $y$ nuch-brancbed panicle; corolla rotate, often 4-parted, in our species with a pair of nectariferous pits at the base of the lobes surrounded by a funnel-shaped crest or a fringed scale; stamens versatile; orary lanceolate, bearing the linear stigmas decurrent down the sides on the sutures; ovules abundant on the broad placenta on both sides of the sutures; capsule oval, compressed; seeds oblong, smootb. 
Swertia * Perennis, L., Gray, Syn. 124.-A span to a foot high; lowest leaves oblong or obovate, $2-4^{\prime}$ long; upper few and narrow, sessile; flowers $1^{\prime}$ wide.-Colorado and Utah mountains, in boggy places; also in Europe and Asia.

Frasera speciosa, Dougl. in Griseb. Gent. 329. Hook. Fl. 2, 66, tab. 153; Gray, Syn. 125.-Biennial; stem stout, $2-6^{\circ}$ high, very leafy; leaves in fours and sixes, nervose, the radical and lower cauline ones linearoblong, 6-10' long, acutish or obtuse, the upper narrower and shorter; flowers numerous, in a long leafy thyrsus; lobes of the greenish-white (rarely bluish) dotted corolla oval-oblong, acutish ( $6^{\prime \prime}$ long), bearing a pair of contiguous and densely long-fringed glands about the middle, and a distant transversely inserted and setaceously multifid scale-like crown near the base; anthers versatile; capsule compressed contrary to the deep boatshaped valves; oblong seeds flat, margined-Willow Spring, Arizona, Rothrock (251), in 1874; Colorado, Wolf (790), in 1873. A mountain species, found in the Rocky Mountains and westward to California and Oregon.

\section{POLEMONIACEAE.}

By Prof. T. C. Porter.

Phlox longifolia, Nutt. (Gray, Proc. Am. Acad. 8, p. 255; Watson in King's Rep. 5, p. 260).-Nevada, 1871, 1872, Watson's Rep.; Boulder, Colo., 1873, Loew (680); Central Colorado, 1873, Wolf (681).

Phlox longifolia, Nutt., var. StansbukiI, Gray.-Arizona and Nevada, 1871, 1872, Watson's Rep.

Phlox nana, Nutt. (Pl. Gamb. p. 4 ; Gray, Proc. Am. Acad. 8, p. 256; Watson, l. c. p. 464).-Santa Fé, N. Mex., June, 1874, Rothrock (8).

Phlox Dovglasi, Hook. (Gray, l.c. p. 254; Watson, l.c. p. 260).Nevada and Arizona, 1871, 1872, Watson's Rep.

Phlox caspitosa, Nutt (Gray, l. c. p. 253; Watson, l. c. p. 259).Nevada and Utah, 1871, 1872, Watson's Rep.; South Park, Colorado, July, 1873, Wolf.

\footnotetext{
* Swertia, L.-Single-stemmed perennials; leaves occasionally alternate, the lowest ones tapering into an elongated, margined petiole; inflorescence thyrsoid; flowers blue; corolla rotate, with a very short tabe; nectariferous pits at the base of its lobes crested with a fringe; anthers versatile; seeds flat, winged.
} 
Collomia linearis, Nutt (Watson, 7. c. p. 261).-Utah, Watson's Rep.; South Park, Colorado, July, 1873, Wolf $(686,687)$.

Collomia gracilis, Dougl. (Watson, l. c. p. 262).-Denver, Colo., June, 1873, Wolf (354).

Collomia gillo:des, Benth. (Gilia divaricata, Nutt. Pl. Gamb. p. 4; Watson, l. c. p. 464).-Willow Spring, Arizona, July, 1874, Rothrock (233).

Collomia Cavanillesiakia, Don. (Gray, $l$. c. p. 260 ; Watson, $l$. $c$. p. 465).-Big Dry Fork, Arizona, 1873, Loew (678); Camp Grant, at 5,250 feet elevation, Rothrock (439); Chiricahua Mountains, August 1, 1874, Rothrock (536); Black River, at 4,500 feet elevation, September, i 874, Rothrock (788).

Collomia longlflora, Gray (Proc. Am. Acad. 8, p. 261; Watson, l. c. p. 465).-San Francisco Mountains, Arizona, 1871, 1872, Watson's Rep.; Denver, Colo., June, 1873, Wolf $(675,677)$; deserts of New Mexico, 1873, Loew ; Camp Bowie, Aris., August, 18i4, Rothock (4i2); Deer Spring (180).

Collomia aggregata (Gilia aggregata, Spieng; Watson, l.c. p. 269).Arizona, Nevada, and Utah, 1871, 1872, Watson's Rep; Arizona, 1873, Loew (305, 744); Blue River, Colorado, June, 1873, Wolf (745); Rocky Cañon, Arizona, July, 1874, Rothrock (275); White Mountains, Arizona, at 9,000 feet elevation, September, 1874, Rothrock (810).-An examination of a goodly number of specimens of Gilia aggregata, Spreng., from different stations in the Rocky Mountains and California, brings to light a character in the species which has been overlooked,-the unequal insertion of the stamens. The degrees of variation in this respect are remarkable and so gradual as to rule out the supposition of dimorphism. In the extreme cases, they are included, on the one side, in the tube of the corolla and very unequally inserted at points wide apart, from the base upward, whilst, on the other, they are crowded toward the throat and more or less exserted. Then, the insertion sometimes is, or rather, perhaps, appears to be, equal. In a specimen of this kind from California, it would be hard to declare that the filaments in some of the flowers do not start out from the same horizontal line, whilst in other flowers on the same stalk their insertion is decidedly unequal. Now, as the main character which separates Collomia fiom Gitia is the unequal inser- 
tion of stamens, I have ventured to transfer this species to the former genus, where it naturally falls into Dr. Gray's section Phloganthea, and forms a link of transition between the two genera. It may be here remarked that the character of Gilia given by Bentham and Hooker (Genera, 2, p. 822), "semina nunquam spirillifera", is evidently an oversight, since Dr. Gray, whose elaboration of the genus is adopted in full, restricts it to the species with opposite and palmately-cleft leaves.

Gilia nudicaulis, Gray (Watson, l. c. p. 264).-South Park, Colorado, 1873 , Wolf.

Gilia Nuttalli, Gray (Watson, l. c. p. 264).-Oro City, Colo., July, 1873, Wolf (682); Arizona, 1873, Loew (164a).

Gilia Pungens, Benth.-Denver, Colo., June, 1873, Wolf; Nevada, 1871, 1872, Watson's Rep.

Gilia debilis, Watson (Am. Naturalist, 7, p. 302 ; Report for 1871, 1872).- Stems short and slender, 1-2 inches high, leafy above; pubescence minute or hirsute; leaves alternate, $\frac{1}{2}-1$ inch long, oblong, attenuate into a short petiole, entire, or some of them broader and 3-lobed; bracts entire, resembling the leaves, twice longer than the calyx; flowers nearly sessile; calyx with ovate-triangular teeth, shorter than the tube; corolla funnelform, 8 lines long, with elongated tube and deeply-lobed limb, light purple; stamens upon the throat exserted; capsule 1 line long, the cells 1-seeded; seeds without mucilage or spiricles.-Southern Utah, 1871, 1872.-PLATF XIX, Fig. A. Natural size. Figure 1. Flower, and, 2, Corolla split open, each enlarged about 5 diameters.

Gilis Demissa, in the same plate, not being collected by the Expedition, is not described. See Gray, Syn. Fl. N. Am. part 1, p. 137.

Gilla densifolia, Benth. (Watson, l.c.p. 468).-A foot or two high, from a perennial root; stems virgate from a woody base, leafy to the top; leaves rigid, linear, laciniate-pinnatifid or incised, the short lobes few or several, subulate; flowers numerous, in a compact head; corolla over half an inch in length, violet-blue, two or three times the length of the calyx (the lobes three lines long); anthers linear-sagittate; ovules several (Gray, in Bot. Cal. 1, p. 495).-Nevarla, 1871, 1872. 
Gilis filifolis, Nutt., var. Diffusa, Gray (Watson, l. c. p. 267).Nevada, 1871, 1872.

Gilia congesta, Hook. (Watson, l. c. p. 268).-Gray's Peak, Colorado, at 10-12,000 feet elevation, July, 1873 , Wolf $(748,749)$.

Gilia pinnatifida, Nutt. (Watson, l. c., p. 469).-Denver, Colo., June, 1873, Wolf (746).

Polemonium humile, Willd. (Watson, l. c. p. 470).-Utah, 1871, 1872 ; Georgetown, at 8,500 feet elevation, and Gray's Peak, Colorado, at 12,000 feet elevation, 1873, Wolf (685).

Polemonium ceruleum, Linn. (Gray's Man. p. 371).-Central Colorado, at 10-11,000 feet elevation, July, 1873, Wolf (683).

Polemonium ceruleum, L., var. foliosissimum, Gray (Watson, $l$. $c$. p. 272).-Utah, 1871, 1872.

Polemonium confertum; Gray (Watson, l. c. p. 272).-Utah, and Belmont, Nev., 1871, 1872; Central Colorado, at 12,000 feet elevation, July, 1873, Wolf (684).

\section{HYDROPHYLLACEA.}

Phacelia* circinata, Jacq. f.-Loew, Arizona. A widely distributed and polymorphic species.

Phacelia crenulata, Torr.-Nevada.

Phicelia glandulosa, Nutt-Annual, viscidly pubescent, somewhat glandulose; leaves bi-pinnately parted; lobes short and obtuse; seeds delicately impressed-punctate; calyx-lobes oblong, spatulate, obtuse; placentæ 2-ovuled; seeds vertical.-Agua Azule, N. Mex., 6,700 feet altitude (131). P. Popei, Torr. \& Gray, Pac. R. R. Rep. 2, p. 172, t. 10, is simply a less hairy form, having the lobes of the corolla entire. Colorado, along the Arkansas (99).

Var. Neo-Mexicana, Gray. (P.Neo-Mexicana,Thurb.in Bot. Mex. Bound.

- Princelua, Juse,_- Calsx deeply 5-parted; the divisione usually narrow and similar. Corolla from almost rotate to narrow-funnelform, deciduous, commonly with appendages upon the inside of the tube in the form of 10 vertical plateg or lamellæ approximate in pairs between the bases of the filaments, or else aduate more or less to their base, one on each side. Stanens equally inserted low town or at the lase of the corolla. Ovules and seeds from 4 (a pair to each placenta) to very numerous-Herbs, mostly branchen from the base; with simple or compound alternate leaves, or the lower oppesite, aud mure or less scorpnid spicate or sacemose cymose intiorescence. Corolla blne, violet, purple or white, never yellow, except semetimes the lube or throat."-Fl. Canifornia, 1, p. :066. 
p. 143) is distinguished chiefly by the more distinctly crenulate-denticulate lobes of the corolla, a character in which it varies much.-Neutria, N. Mex., at 7,000 feet altitude (155).

Phacelia tanacetifolia, Benth.-Valley of the Arkansas, Colorado (82). (By oversight published in catalogue (1874) as sub-alpine.)

Phacelia sericea, Gray.-Nevada.

Phacelia integrifolia, Torr--Deer Spring, Arizona, at 6,300 feet; hairy form, but hardly, I think, P. Palmeri, Torr., in Watson's Bot. King's Survey, p. 251 (181).

Hydrophyllum Virginicum, L.-Apex, Colo. (83).

Hydrophyllum capitatum, Dougl.-Utah.

Nama hispida, Gray.-Camp Bowie, Ariz., at 5,500 feet altitude (445).

Eriodictyon* glutinosum, Benth., var. angustifolium, Torr. ( $E$. angustifolium, Nutt. Pl. Gambel, 181).-Nearly smooth, with a sticky exudation; linear leaves with revolute margins; inflorescence cymose in a naked panicle; short campanulate corolla 2-3" long.-Southern Nevada.

\section{BORRAGINACEE.}

By Prof. T. C. Porter.

Coldenia hispidissima, Gray (Watson, Bot. King, p. 247).-Nevada, 1871, 1872, Watson's Rep. (Eddya, Torr. Pac. R R. Rep. 2, p. 170, pl. ix); Sunset Crossing, Ariz., 1873, Loew (160 a).

Coldenia Palmeri, Gray (Watson, l. c. p. 248).-Nevada, 1871, 1872, Watson's Rep.

Heliotropium Curassavicum, Linn. (Gray's Man. p. 366; Watson, Bot. King, p. 248).-Nevada, 1871, 1872, Watson's Rep.

Heliotropium convolvulaceum, Gray (Bot. Cal. 1, p. 521; Euploca, Nutt.).-Annual, with branches a span to a foot long spreading from the

* Eiriodictyon, Benth.-Calyx deeply 5-parted, the lobes or sepals not broader upward. Corolla funnel-form or approaching campanulate or salver-form. Stamens more or less included. Styles 2 , distinct to the base; their tips or stigmas clavate-capitate. Capsule crustaceous, small, globose-ovate and pointed, 2-celled, with dilated placentæ, 4-valved, i.e., at first loculicidal in the manner of the tribe, then septicidal, thus splitting into four hard and thick half.valves, elosed by a portion of the partition on one side and partly open on the other. Ovules rather numeruus, bat seeds few.-Low shrubs; leaves alteruate, of rigid coriaceous texture, their margins beset with rigid teeth, the base tapering into more or less of a petiole. Flowers in scorpioid cymes collected iu a terminal panicle; corolla violot or purple, varying to white. Filaments variably adnate to the tabe of the corollis.-GraY, Fl. Cal. 1, p. 518. 
base, hoary or strigose-hispid; leaves oblong-lanceolate or ovate, petioled; flowers scattered, short-pedicelled, sweet-scented; corolla white, with a rotate limb, plaited but scarcely lobed, and a hairy tube somewhat enlarged above, and the orifice narrowed; anthers with slightly cohering tips; style long; truncate cone of the stigma bearded with stiff bristles; fruit of two globose, solid lobes, each lobe or carpel splitting into two hemispherical one-seeded nutlets.-Deserts of New Mexico, 1873, Loew

Echinospermum Redowskir, Lehm. (Gray's Man. p. 365; Watson, Bot. King, p. 246).-Nevada, 1871, 1872, Watson's Rep.; Twin Lakes, Colorado, 1873, Wolf $(694,705)$; Pescado, N. Mex., at 7,000 feet elevation, July, 1874, Rothrock (154).

Echinospermum floribundus, Lehm. (E. deflexum, Lehm., var floribundum, Watson, Bot. King, p. 246).-Twin Lakes, Colorado, 1873, Wolf (697).

Eritrichium nanum, Schrad, var. aretioides, Herder. (Gray, Proc. Am. Acad. 10, p. 56 ; E. aretioides, DC. ; E. villosum, DC., var. aretioides, Gray; Watson, Bot. King, p. 241).-Mountains of Colorado, at 13,000 feet elevation; June, 1873, Wolf (708).

Eritrichium Californicum, DC. (Watson, Bot. King, p. 24\%).-Central Colorado, 1873, Wolf $(689,691,692)$.

Eritrichium angustirolium, Torr. (Watson, l.c. p. 241).-San Luis Valley, Colorado, September, 1873, Wolf (704).

Eritrichium crassisepalum, Torr. \& Gray (P. R. R. Survey, 2, p 171).-Annual, very hispid with spreading hairs; stem much branched from the base, branches ascending, 3 to 5 inches high; leaves obovate-lanceolate, rather obtuse; racemes bracteate below; fructiferous calyx ventricose at base, closed and contracted above the middle, the segments thickened and indurated on the back, finely pilose on the margins, with large, strong, hispid hairs on the back; nutlets heteromorphous, ovate, convex on the back, three of them muricate-granulate, the fourth larger and nearly or quite glabrous.-Colorado, 1873, Wolf.

Eritrichium Jamesir, Torr. (Marey's Rep. p. 294).-Hirsute, much branched from a suffruticose base; branches 6 to 10 inches high; leaves linear-lanceolate, tapering to the base, 1 to 2 inches long; spikes terminal, 
numerous; flowers on very short pedicels; calyx campanulate, at first scarcely longer than the tube of the corolla, but in fruit elongated and closed, segments ovate; corolla ochroleucous, tube shorter than the calyxteeth, spreading limb 2 to 3 lines wide, lobes very obtuse; nutlets 4 , similar, depressed, conniving at the top, but separated at the sides, very convex and smooth on the back, shining, edges very acute, ventral suture adhering to the style above the middle.-Denver, Colorado, June, 1873, Wolf (696); Western New Mexico, at 6,500 feet elevation, July, 1874, Rothrock (130).

Eritrichium glomerateum, DC. (Watson, Bot. King, p. 242).-Twin Lakes, Colorado, July, 1873, Wolf (700, 702).

Mertensia oblongifolia, DC. (Watson, Bot. King, p. 238).-Apex, Colo., 1873, Wolf (709 a).

Mertensia Sibirica, Don.-Utah, 1871, 1872, Watson's Rep.; Colorado, 1873 , Wolf $(709 b)$.

Mertensia paniculata, Don.-Arizona, 1873, Loew (162 a) ; Colorado, 1873; Wolf (709).

Mertensia lanceolata, DC. Prod. 10, p. 88 (Pulmonaria lanceolata, Pursh, and P. marginata, Nutt., Gray, Proc. Am. Acad. 10, p. 53).- Stem erect, glabrous, about one foot high; leaves glaucescent, somewhat fleshy, ciliate, lower oblong-spatulate or oblong-ovate, upper ovate, acute, partly clasping; racemes 4- to 8-flowered, sub-fasciculate, scarcely longer than the leaves; corolla with a funnel-form tube twice longer than the calyx; stamens inserted in the throat; anthers sagittate - Willow Spring, Arizona, at 7,400 feet elevation, July, 1874, Rothrock (246).

Lithospermum pilosum, Nutt. (Watson, Bot. King, p. 238).-Utah, 1871, 1872, Watson's Rep.

Lithospermum multiflorum, Torr. (Watson, Bot. King, p. 238, under L. pilosum, Gray, Proc. Am. Acad. 10, p. 51).-New Mexico, 1873, Loew (161 a); Grant Post Office, Colo., July;, 1873, Wolf (698); Willow Spring, Arizona, at 7,i95 feet elevation, July, 1874, Rothrock (201).

Lithospermum canescens, Lehm., var. (Gray's Man. p. 363).-Tonto Basin, Arizona, 1873, Loew (162 a) ; Willow Spring, at 8,000 feet elevation, and Sanoita Valley, Southern Arizona, at 4,000 feet elevation, 1874, Rothrock $(202,633)$. 
Onosmodium Thurberi, Gray, Syn. Fl. p. 205. (Macromeria viridiflora, Torr. in Mex. Bound. Surv. p. 139, not of A. DC.)-Stem erect, 2 to 3 feet high hispid with spreading hairs; leaves ovatc-lanceolate, 2 to $3 \frac{1}{2}$ inches long, 6 to 12 lines wide, covered on both sides with a close appressed pubescence, hispid also on the upper side with stiffish, erect hairs arising from a callous base, and on the under side with softer, somewhat villous hairs, especially on the rib-like nerves, sessile and partly clasping; flowers one inch and a half long, tubular-funnelform, greenish and very hairy on the outside, yellow within; calyx about one-fourth the length of the corolla, the divisions much elongated in fruit; stamens at first included, but at length exserted; nutlets ovate, more than a line long, smooth and shining. Willow Spring, Arizona, 1874, Rothrock (227).

\section{CONVOLVULACE E.}

Ipomea hederacea, Jacq. Gray, Syn. Fl. part 1, p. 210. (Ipomoa Nil, Roth.)-Southern Arizona (505, 524), where it forms dense masses, often an acre in area.

Ipomega Mexicana, Gray, Syn. Fl. part 1, p. 210. (Ipomoea Nil, var. diversifolia, Choisy in DC. Prod. ix, p. 343. Pharbitis diversifolia, Lindl. Bot. Reg. t. 1988)-Probably only a form, distinguished (so far as my specimen shows) by its shorter, broader calyx-lobes, and also, on authority of Choisy, by the lower leaves being cordate-acuminate, and the others 3-lobed.-Arizona (150 $a$, Loew).

Ipomøa muricata, Cav.-Nearly smooth, with a tuberose root; stem prostrate; leaves deeply palmately-parted, the 6-8 divisions narrowly linear, but slightly dilated upward, 4-9" long, petiole $1^{\prime \prime}$ long; corolla 12-14" long, purple, tube slender; sepals ovate or lance-ovate, obtuse or slightly mucronate, evidently muriculate on the back. The slender stems hardly a foot long; flowers infundibuliform and somewhat disproportionately large.-Sanoita Valley, Arizona (623).

Iромба costellata, Torr.-Herbaceous, smoothish or somewhat hairy, branching, slender; leaves palmately-parted, 5-7 divisions, which are linear to lanceolate-spatulate, and sometimes sparingly ciliate, 4-7" long; petioles $2-5$ " long; pedicels slightly thickened; flowers purple or whitish, funnel- 
shaped; lobes short; sepals oblong, margins slightly scarious, distinctly 2-3keeled; style entire, the 2-lobed stigma very slightly roughened; seeds in my specimens smooth or nearly so. (590 a hairy form.)-Southern Arizona (631, 679, 623 a); common.

IPOMCE LePTOPHyLla, Torr.-Perennial ; stems smooth, often erect and bushy, usually prostrate; leaves thickish, sessile, entire, acute, lance-linear, $3^{\prime}$ long, veiny; peduncles 1-3-flowered; sepals ovate, obtuse, somewhat mucronate. Corolla with a spreading border, $1_{2}^{1^{\prime}}$ across; tube $1_{\frac{2}{2}}^{\prime}$ long; filaments hairy below, inserted near the base of the corolla; style equalling the stamens, lobes of the stigma capitate.-Loew; probably from along the Arkansas.

Ipomøa coccinea, L. (Quamoclit coccinea, Mœnch).-Southern Arizona (559).

Convolvulus sepium, L., var. RePens, Gray (Calystegia sepium, R. Br., var. pubescens, Gray).-Zuñi, N. Mex, 6,500 feet altitude (162).

Convolvulus incanus, Vahl.-Twining, silky-hairy; stems terete; leaves linear-lanceolate, 9-18 $8^{\prime \prime}$ long, somewhat cordate, and distinctly auricled at base; auricles diverging and recurved, entire or more or less deeply 2-3-lobed; petioles 2-6" long; peduncles $1-2 \frac{1}{2}^{\prime}$ long, bearing a pair of small bracts above the middle; sepals villous, ovate, rather obtuse, half as long as the broadly infundibuliform hairy corolla; lobes of corolla distinctly hairy-tipped.-Arizona (Loew, 150 a); (482) at 5,300 feet altitude.

Convolvulus longipes, Watson (American Naturalist, 7, 302).—"Glabrous, glaucous, twining; leaves linear, 1 inch long or less, entire or auricled at base, petioled; peduncles elongated, 2-6 inches long, mostly strict, 2-3bracted, usually 1-flowered; bracts linear; calyx-lobes rounded, obtuse or

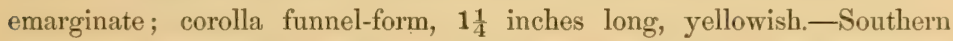
Nevada."-Plate XX. Fig. 1. Natural size. 2 Pistil. 3. Cross-section of ovary. 4. Stamen. Figs. 2, 3, and 4 enlarged.

Evolvulus* SERICeus, Swartz.-Spreading, procumbent, branches 4-8' long; leaves sessile, lanceolate to oblong, acute or obtuse, smooth or nearly so above, densely silky-hairy below; pedicels axillary, 1-3" long; sepals

*Evolvulus, L.-A genus of about 70 species, natives mostly of Tropical America; distinguished from Convolvulus in having two styles, and each of these being divided into two linear-filiform stigmas : and also by the ovary being sometimes 1 -celled from the disappearance of the partition. 
lanceolate, hairy, acute, as long as or exceeding the pedicels; corolla whitish, 6" long. Choisy, in DC. Prod. vol. ix, p. 443, speaks of the peduncles as being 1-3-flowered. In all my specimens, the flowers are solitary.-Ash Creek, Arizona (152 a, Loew, and 307).

Evolvulus Arizonicus, Gray.-Procumbent or ascending, 6-12' long, silky-hairy; leaves linear-lanceolate to lanceolate, acute, 4-10" long; peduncles capillary, 6-18" long, bractoate at the forks and bearing 1-3 flowers (usually 3 ); flowers blue, $6-8^{\prime \prime}$ in diameter, salver-shaped; sepals acute; anthers distinetly auriculate at base; pedicels reflexed after fall of the flower; ovary 1-celled.-Camp Grant, Ariz. (376 and 151 a, Loew, Arizona).

Cressa Cretica, L., var. Truxillensis, Chois--Arizona.

\section{CUSCUTER.}

By Dr. George Engelmann.

Cuscuta (Chistogrammica) salina, Engelm.-Stems slender, low; flowers ( $1 \frac{1}{2}-2 \frac{1}{2}$ lines long) delicate white, pedicelled in loose cymes; calyxlobes ovate-lanceolate acute, as long as the similar but mostly broader and overlapping denticulate lobes, and as the shallow-campanulate tube of the corolla ; filaments about as long as the oval anthers; fringed scales mostly shorter than the tube, sometimes incomplete; styles equalling or shorter than the somewhat pointed ovary; capsule surrounded (not covered) by the withering corolla, mostly 1 -seeded.

Saline or brackish marshes in the Gila Valley on Sucda, Rothrock (333), 1874; also on the California coast, near Santa Barbara, on Frankenia and Salsola, Rothrock (101), 1875. Similar to C. Californica, from which it is at once distinguished by its larger flowers and the presence of the infra-stanineal scales.

Cuscuta (Clistogramaica) arvensis, Beyrich-Ash Creek, on Solidago, Rothrock (311), 1874, and Camp Lowell, on Datura meteloides, Rothrock (71:8), 1874. These specimens, especially the latter, growing on a very juicy nurse-plant, have coarser stems than the Southeastern form and larger flowers and fruit; the calyx is not angular, its lobes rounded; those of the corolla very acute. 
Cuscuta (Clistogrammica) decora, Choisy, Engelm.-In the Gila Valley on a low, spiny, rhamaceous shrub. Rothrock (326), 1874. A large form, the same as the one from California.

\section{SOLANACEA.}

Solanum nigrum, L., var. Douglasir, Gray ( $S$. Douglasii, Dunal, in DC. Prod. xiii, p. 48).-Glabrous or even tomentose-puberulent leaves (sometimes in California specimens thickish, on short petioles) deeply and irregularly crenate; flowers $6^{\prime \prime}$ in diameter.-Camp Grant, Ariz. (388).

Var. Dillenir, Gray (or near it, fide Professor Gray). (S. Dillenii, Dunal, DC. Prod. xiii, p. 47.) —-Slightly puberulent; leaves entire or nearly so, acute, attenuate into a petiole, $2-3 \frac{1}{2}^{\prime}$ long and one-third as wide; flowers umbellate, erect; short filaments more or less hairy; fruit reflexed; style hairy, especially at base, and geniculate toward the capitate stigma; flowers $4^{\prime \prime}$ in diameter.-Camp Lowell, Ariz. (707). Very slender and straggling herb. Probably the same as S. nodiflorum of the Mex. Bound. Survey.

Solanum Jamesir, Torr. (in Ann. Lyc. N. Y. 2, p. 227, and Gray in Sill. Jour. n. ser. 22, p. 284).-Glabrous, or with a few longish hairs; leaves oval; leaflets 7-11, decreasing and becoming distant toward the base, slightly decurrent; calyx-lobes triangular-ovate, half as long as the corolla; filaments smooth; style smooth, moderateły thickened upwardly; stigma slightly two. lobed and capitate; inner valve of the anthers so conspicuously shorter than the outer as to make the anthers (seen from the extremity) almost bilabiate; racemes extra-axillary, 4-5-flowered-Loew, Arizona (158 a).

Solanum triflorum, Nutt.-Herbaceous or a little woody at base, unarmed, much branched, somewhat chaffy-hairy; leaves petioled, lanceolate to oval, deeply sinuate, or runcinate-lobed; calyx-lobes oblong, obtuse, somewhat hairy; flower $4^{\prime \prime}$ in diameter, whitish; fruit $6^{\prime \prime}$ in diameter, smooth, dark, reflexed.-South Park and Colorado Springs, Colorado (88).

Solanum rostratum, Dunal-A well-marked, prickly species, with a slightly irregular, yellow corolla, one anther larger than the rest, and prolonged into a somewhat curved beak, the prickly calyx inclosing the fruit-Arizona, Loew.

Solanum elexagifolium, Cav.--Stems and midribs usually with short 
and rather weak prickles; entire plant whitish, with a dense stellate pubescence; leaves lanceolate, entire, or wavy-margined (sometimes slightly lobed); flower blue, $9^{\prime \prime}$ in diameter, the linear anthers opening .only at the tip; ovary tomentose ; mature berry black, $6^{\prime \prime}$ in diameterNew Mexico and Arizona (83, 342).

Chamesaracha* sordida, Gray (Withania? sordida, Dunal, in DC. Prod. xiii, p. 456; also in Bot. Mex. Bound. p. 155).-Branching, somewhat glandular-pubescent; leaves oblanceolate, entire, attenuate into a petiole; calyx glandular-hairy, with forked hairs; corolla sulphur-yellow, $6^{\prime \prime}$ in diameter; stamens sub-exserted; style clavate; stigma sub-capitate.Camp Bowie, Arizona, at 5,300 feet (471).

Chamesaracha Coronopus, Gray (Withania? Coronopus, Torr. Bot. Mex. Bound. p. 155).-Smoothish or slightly glandular-hairy, branching; leaves linear-lanceolate, attenuate into a petiole, irregularly deeply sinuatetoothed, thickish; calyx with forked hairs. Corolla light yellow; stamens sub-included; style clavate; stigma sub-capitate-McArthy's Ranch, New Mexico (111). Notwithstanding the difference in leaves usually manifested by these two species, there is a decided tendency for them to vary toward each other; this along with the similar pubescence, the close resemblance of the flowers, and the same prominently ridged and roughened campylotropous seeds, make me feel almost sure they will have to come together.

Physalis lobata, Torr.-Low, spreading; root perennial; leaves oval or spatulate, tapering into a margined petiole. Corolla violet-purple; fruiting calyx $6^{\prime \prime}$ in diameter, winged, inflated; entire plant glabrous, except the young calyx and pedicels, which are "mealy"; seeds thickish, somewhat tuberculate roughened.-Deer Spring, Arizona, 6,000 feet altitude (189).

Physalis viscosa, L.-Utah.

"Physalis — - Near P. pubescens, but leaves small and mostly

* "Сhamesaracha, Gray.-Calyx 5-lobed, enlarging after flowering, bnt remaining rather berbaceons, not reticulated, incompletely investing the rather dry-globose berry. Corolla rotate, 5-angulate. Authers short, on slender (not at all convivent) flaments, the cells opening lengthwise throughout.-Low. Texano-Californian berbs; with the corolla of Saracha and a calyx between that of Solanum and Physalis, with rather narrow leaves tapering into margined petioles, and in their axils filiform solitary or sometimes geminate pedicels, which are mostly refracted, or recurved in fruit. Corolla white, yellowish, or tinged witls violet."-GkaY, Fl. Cal. 1, p. 540. 
suborbicular; stems flexuose--Arizona."-(Watson in Wheeler's Preliminary Report, 1874, p. 14.)

Lycium Pallidum, Miers.-Fruit eaten, but insipid. El Puerco, N. Mex., at 5,000 feet altitude, on dry gravel soils or mesas (90).

Lycium Andersoni, Gray, var. Wrightir, Gray.-The variety is only a more leafy, fewer- and smaller-flowered, spiny form of the species.-Camp Bowie, Ariz. (448). Nevada.

Datura meteloides, DC.-Perennial, 2-4 ${ }^{\circ}$ high, whitish from a very close soft pubescence ; calyx (flowering) $2-4^{\prime}$ long, $6-8^{\prime \prime}$ in diameter; corolla pale blue, regularly funnel-shaped, 6-9' long and about $5^{\prime}$ in diameter across the mouth, with 5 slender, delicate lobes 6-12" long. Capsule prickly, nodding on a short peduncle, when ripe opening irregularly; seeds surrounded with a cord-like margin. This is the common Datura Wrightii of the gardens.-Common in the southern and southwestern part of the United States, and extending into Mexico-Camp Grant, Ariz. (381).

Nicotiana trigonophylla, Dunal--Usually rather slender, $2^{\circ}$ high, from a hardened or woody base. Viscidly pubescent; leaves lanceolateoblong, obtuse or acute, tapering to a petiole, or dilated auriculate at base; flowers pedicellate, somewhat unilateral by a curve in some of the pedicels, greenish or yellowish-white, about $\mathbf{1}^{\prime}$ long; orifice often a little constricted; lobes short, spreading slightly; calyx-lobes variable, from narrowly to broadly triangular.-Camp Crittenden, Southern Arizona, at 5,000 feet altitude. No. 354, from Cottonwood, Arizona, appears to be a form of this species, but has longer, narrower calyx-lobes, and much more spreading and acute lobes to the corolla. It is withal also a much more branching plant.

Nicotiana attenuata, Torr.-Nevada and Utah.

\section{SCROPHULARINE E.}

By Prof. T. C. Porter.

Verbascum Thapsus, Linn. (Gray's Man. p. 325).-Utah, 1871, 1872, Watson's Report.

Antirrhinum maurandioides, Gray (Proc. Am. Acad. 7, p. 376. 14 вот 
Maurandia antirrhinifora, Willd. DC. Prod. 10, p. 296).-Glabrous, diffusely branching; branches slender, climbing high by the flexuose and prehensile petioles and peduncles; leaves numerous, triangular-hastate or sagittate, rarely cordate-hastate, angulate; pedicels axillary; segments of the calyx lanceolate, 5 to 6 lines long, very smooth; corolla scarce an inch long, smooth, its prominent palate pilose and almost elosing the throat.-Arizona, 1871, 1872, Watson's Report ; 1874, Rothrock (93 a); Cottonwood, Arizona, at 4,500 feet elevation, July, 1874, Rothrock (353); Camp Crittenden, September, 1874, Rothrock (680).

Scrophularia nodosa, Linn. (Gray's Man. p. 327).-Mount Graham, Arizona, at 9,250 feet elevation, August, 1874, Rothrock (410).

Collinsia Parviflora, Dougl. (Gray's Man. p. 327).-Nevada, 1871, 1872, Watson's Report; Apex, Colo, 1873, Wolf (328).

Pentstemon barbatus, Nutt., var. Torreyi, Gray (Watson's, Bot. King, p. 452).-Arizona, 1873, Loew (304).

Pentstemon barbatus, Nutt, var. trichander, Gray (Proc. Am. Acad. 11, p. 94).-Anthers sparingly bearded with long wool.-Zuñi Mountains, New Mexico, at 7,000 feet elevation, July, 1874, Rothrock (151).

Pentstemon glaber, Pursh (Watson, l. c. p. 217).-Nevada and Utah, 1871, 1872, Watson's Report; Plains of Colorado, 1873, Wolf (299); Neutria, N. Mex., at 7,100 feet elevation (147).

Pentstemon Fremonti, T. \& G. (Watson, l. c. p. 218).-Nevada and Utah, 1871, 1872, Watson's Report.

Pentstemon caruleus, Nutt. (Watson, l. c. p. 218).-Denver, Colo., 1873, Wolf (291, 296).

Pentstemon acuminatus, Dougl. (Watson, l. c. p. 218).--South Park, Colorado, 1873, Wolf (302).

Pentstemon secundiflonus, Benth. (DC. Prod. 10, p. 325).-Glabrous,

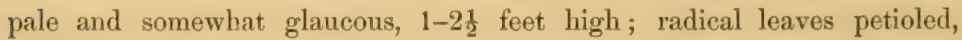
elliptic-spatulate or narrowly lanceolate, obtuse or acute, upper ones lanceolate or linear-lanceolate, sessile, middle ones 3 to 4 inches long, erect; thyrsus elongated, narrow, 6 to 9 inches long, interrupted; cymes secund, few- to many-flowered; segments of the calyx oval-oblong, acute or acutish, with membranous margins; tube of the corolla more or less abruptly 
enlarged below the middle; anthers glabrous or very minutely puberulent; sterile filament dilated at the apex, bearded or smooth.-Arizona?, 1873, Loew (159 a); South Park, Colorado, August, 1873, Wolf (300); Mount Graham, Arizona, at 9,250 feet elevation, August, 1874, Rothrock (400).

Pentstemon Eatoni, Gray, Proc. Am. Acad. 8, p. 395 (P. centranthifolius, Watson, Bot. King, p. 219, not Benth).-Utah ; Belmont, Nev., 1871, 1872, Watson's Report.

Pentstemon Wrightil, Hook. (Watson, l. c. p. 453).-Utah, 1871, 1872, Watson's Report.

Pentstemon virgatus, Gray (Watson, l. c. p 453).-Neutria, N. Mex., at 7,100 feet elevation, July, 1874, Rothrock (150.)-Arizona, Rothrock (264).

Pentstemon ambiguus, Torr. (Ann. N. Y. Lye. 2, p. 228; Marey's Rep. p. 279, t. 16).-Glabrous, 1 to 2 feet high, paniculately branching from a woody base; lower leaves linear, attenuated below, upper ones subulatefiliform or acerose-subulate; racemes loosely flowered; peduncles opposite ; corolla scarcely bilabiate, 5 to 8 lines long; tube 6 lines long, little dilated above, often incurved, the spreading limb 6 lines in diameter; sterile filaments glabrous.-Western New Mexico and Eastern Arizona, 1873, Loew $(688,860)$; Algodones, N. Mex , at 6,000 feet elevation, June, 1874, Rothrock (79); Camp Grant, August, 1874, Rothrock (440).

Pentstemon linarioides, Gray (Proc. Am. Acad. 6, p 66).-Minutely pruinose-puberulent; stems 6 to 18 inches high, many, from a woody base, very leafy; leaves 1 inch long or less, spatulate-linear to subulate; peduncles and pedicels short, alternate; panicle narrow, sub-secund; corolla purplish, short-bilabiate, over $\frac{1}{2}$ an inch long, much dilated above; palate and sterile filament bearded-Arizona, 1871, 1872, Watson's Report; "Tanks," south of Camp Apache, July, 1874, Rothrock (265).

Pentstemon albidus, Nutt (Gray, l. $c$ p. p7) -Stem puberulent, 6 to 9 inches high; lower leaves petioled, oblong, obtuse, sub-entire, upper ones serrate, lanceolate, glabrous or puberulent; thyrsus oblong, subverticillately interrupted; cymes subsessile, few-flowered; sepals lanceolate, very viscid-pubescent; tube of the corolla widened above, three-fourths of 
an inch long, purplish-white, the limb beardless; beard of the sterile filament rather short, somewhat interrupted.-Colorado, 1873, Wolf (292).

Pentstemon cristatus, Nutt. (Watson, Bot King, p. 219).-Agua Azul, N. Mex., July, 1874, Rothrock (129).

Pexistemon Jamesir, Benth. (Gray, l. c. p. 67).-Puberulent, 4 to 12 inches high; leaves linear-lanceolate, often denticulate, rigid; cymelets 3- to 4-flowered in a spicate panicle; sepals viscid-puberulent; corolla I inch or more long, pale purple, abruptly campanulate above, the lip and sterile filaments less bearded than in $P$. cristatus. - Santa Fé, N. Mex., June 1874, Rothrock (2).

Pentstemon humilis, Nutt. (Watson, l. c. p. 220).-South Park, Colorado, 1873, Wolf.

Pentstemon glaucus, Grah., var stenosepalus, Gray (Watson, $l$. c. p. 221).-Utah, 1871, 1872, Watson's Rep. ; mountains of Colorado, 1873, Wolf $(297,298,301)$.

Pentstemon Hallin, Gray (Proc. Am. Acad. 6, p. 70).-Stems 3 to 5 inches high, numerous, glabrous except the very minutely glandular inflorescence; leaves entire, pale, linear-spatulate or linear-attenuate at base; raceme simple, 4-10-flowered with short pedicels; sepals ovate or oblong with scarious and often erose margins; corolla deep blue, about 1 inch long, ventricose-campanulate above the short base, the lips short; the sterile filament short-bearded.-South Park, Colorado, July, 1873, Wolf (303). Var. Arizonicus, Gray, Mount Graham, Arizona, at 9,250 feet elevation, August, 1874, Rothrock (426).

Pentstemon confertus, Dougl., var cereruleo-Purpureus, Gray (Watson, l. c. p. 221).-Nevada and Utah, 1871, 1872, Watson's Rep ; South Park, Colorado, 1873, Wolf (293, 294).

Pentstemon Deustus, Dougl. (Watson, l. c. p. 221).-Nevada, 1871, 1872, Watson's Rep.

Pentstemon L.etus, Gray (Watson, l. c. p. 455).--Mineral Hill, Nevada, 1871, 1872, Watson's Rep.

Chionophila JAMESII, Benth.-Low, glabrous, from a thick rootstock; stem seapiform, 1 to 4 inches high, with a pair of leaves above the middle, terminated by a crowded spike of flowers; radical leaves tapering into the 
expanded, membranaceous, hyaline bases, spatulate or oblong-linear, obtuse, very entire, thickish; flowers 2 to 4 , crowded; bracts opposite, ovate, connate at base, obtuse or acute, unequal; flowers yellowish, on very short pedicels; calyx 4 to 5 lines long, campanulate; teeth broad, obtuse; corolla a little longer; lower lip densely tomentose within.-High alpine. Mountains of Colorado, 1873, Wolf (332).

Mimulus BigeloviI, Gray (Eunanus Bigelovii, Gray, Watson's Bot. King, p. 226).-Nevada, 1871, 1872, Watson's Report.

Mimulus nanus, Hook. \& Arn. (Eunanus Fremonti, Watson, Bot. King, p. 226, not of Benth.).-Nevada, 1871, 1872; Watson's Report.

Mimulus Cardinalis, Dougl. (Gray, Bot. Calif 1, p. 566).-Perennial, 1 to 2 feet or more high, villous with viscid hairs; leaves ovate, the upper often connate, erosely dentate; calyx oblong, prismatic, the short teeth nearly equal; corolla scarlet, $1 \frac{1}{2}$ to 2 inches long, its tube but little longer than the calyx; limb oblique, with the upper lobe erect and the two lateral ones and the lower reflexed; stamens projecting, villous or pubescent.Mount Graham, Arizona, at 9,250 feet elevation, August, 1874, Rothrock (401). Var-Low, with leaves attenuate to the base, Arizona, 1871, 1872, Watson's Report.

Mrmulus Luteus, Linn. (Watson, $l$. c. p. 223).-Nevada, Arizona, and Utah, 1871, 1872, Watson's Report; Twin Lakes, Colorado, at 10,000 feet elevation, 1873, Wolf (313); Santa Fé, N. Mex., 1874, Rothrock (28), at 7,044 feet elevation; Cave Spring, Arizona, July, 1874, Rothrock (193); Eastern Arizona, 1873, Loew (310).

Mimulus Luteus, Linn., var. Alpinus, Gray (Watson, l. c. p. 224).Twin Lakes, Colorado, 1873, Wolf (313 bis).

Mrmulus Jamesi, Torr. (Gray's Man. p. 328).-Denver, Colorado, June, 1873, Wolf (312).

Mrmulus floribundus, Dougl. (Watson, l.c.p. 224).-San Luis Valley, Colorado, September, 1873, Wolf (311).

Mimulus pilosus, Watson (Bot. King, p. 224).-Nevada, Watson's Report.

Herpistis chamedryoides, H. B. K. (DC. Prod. 10, p 393).-Low, decumbent, branching; leaves short-petioled, ovate, cuneate or rarely 
rounded at the base, dentate, commonly 6 to 9 lines long; pedicels solitary, about equalling the leaves in length or a little longer, bractless; calyx in fruit 3 to 5 lines long, the posterior segment ovate, the anterior ovate or oblong, the corolla a little longer than the calyx, the upper lip emarginate.-In wet sand, Camp Lowell, Arizona, September, 1873, Rothrock (709).

Conobea intermedia, Gray (Bound. Surv. p. 117).-Annual, erect, spreading, 2 to 6 inches high, viscid-pubescent; leaves subpimnately-parted; flowers very short-peduncled, purple, twice as large as those of $C$. multifida; cells of the anthers subcontiguous; capsule 3 to 4 lines long, ovate-lanceolate, pointed, one-half longer than the somewhat unequal calyx.-Sanoita Valley, Arizona, at 5,000 feet elevation, July, 1874, Rothrock (649).

Gratiola Virginiana, Linn. (Gray's Man. p. 330).-_San Luis Valley, Colorado, September, 1873, Wolf (323).

Limosella aquatica, Linn. (Gray's Man. p. 331).-The typical form. Leaves with a spatulate-oblong blade.-Twin Lakes and San Luis Valley, Colorado, 1873, Wolf $(972,973,986)$.

Synthyris plantaginea, Benth. (DC. Prod. 10, p. 455).-Woollypubescent, becoming smooth; radical leaves oblong, crenate, thick, coriaceous, 3 to 6 inches long, 2 to $3 \frac{1}{2}$ broad, abruptly narrowed at base and somewhat decurrent on the petiole; petioles 2 to 3 inches long, somewhat pilose on the veins and ribs; scape 6 to 12 inches high, furnished with numerous oblong, or orbicular, nearly sessile bracts; flowers in a dense spike, 6 inches long in fruit; fruit scarcely exceeding the round-ovate, persistent bracts.-Western New Mexico, at 6,500 feet elevation, 1873, Loew (317); Clear Creek and South Park, Colorado, at 8-10,000 feet elevation, June, 1873, Wolf (316).

SyntuYris alpina, Gray (Sillim. Journ. 2d ser. 34, p. 251) -Somewhat woolly, becoming smooth; radical leaves elliptic or oval, sometimes obcordate, closely crenate, 1 to 2 inches long; on slender petioles; scape 2 to 6 inches high, leafy-bracted; spike short, dense, 9 to 12 lines long; sepals lanceolate, villous on the outside toward the edge wifh long hairs as well as the bracts; corolla 2-parted; lobes narrow, purplish-blue; stigma capitate; stamens exserted.-South Park, Colorado, 1873, Wolf. 
Veronica Americana, Schweinitz.-South Park, Colorado, 1873, Wolf (336); Santa Fé, N. Mex, at 7,044 feet elevation, June, 1874, Rothrock (30).

Veronica alpina, Linn.-Mosquito Pass, Colorado, July, 1873, Wolf (332).

Veronica SERPyllifolia, Linn.-Colorado, 1873, Wolf (331, 333).

Veronica PEREgrina, Linn.-Twin Lakes, Colorado, July, 1873, Wolf (330).

Veronica PEREgrina, Linn., var. DIFFusa, Rothrock-Widely and diffusely branched; bracts entirely like the leaves —On alkaline flats, San Luis Valley, Colorado, 1873, Wolf (335).

Gerardia Wrighti, Gray (Bot. Bound. Survey, p. 118).-Stems simple, from a perennial root, virgate, very scabrous, as well as the linearfiliform, sharply mucronate leaves; peduncles as long as the flowers; calyx truncate, with 5 short teeth; corolla yellow, broadly campanulate from a very short tube, pubescent on the outside, very smooth within; filaments short, only villose at the apex; anthers similar, naked, very obtuse, sagittate at base; cells subulate-awned; stigma clavate — Sanoita Valley, Arizona, at 5,500 feet elevation, August, 1874, Rothrock (643). The specinen agrees in every respect with the original description, except that the stem is not simple, but branched. It is probably like our Eastern G. purpurea, which has stems of both kinds. The flowers in the dried state have a yellowish and not a purple tinge.

Castilleia affinis, Hook. \& Arn. (Watson, Bot. King, p. 228).-Zuñi, N. Mex., at 6,500 feet elevation, July, 1874, Rothrock (161); Camp Bowie, Arizona, at 5,300 feet elevation, August, 1874, Rothrock (475).

Castilleia minor, Gray (C. affinis, var. minor, Gray, Watson, $l$. c. p. 228).-Nevada and Utah, 1871, 1872, Watson's Report.

Castilleia linariefolia, Benth. (Watson, $l$. c. p. 228) -Twin Lakes, Colorado, at 9-10,000 feet elevation, July, 1873, Wolf (288).

Castilleia parviflora, Bong. (Watson, l. c. p. 229).-Nevada, 1871, 1872, Watson's Report; Arizona, 1873, Loew (286).

Castilleia integra, Gray (Watson, l. c. p. 456). -San Francisco Mountains, Arizona, 1871, 1872, Watson's Report; Western New Mexico, at 
6,500 feet elevation, July, 1874, Rothrock (128); Colorado, 1873, Wolf $(289,290)$.

C'astilleia Pallida, Kunth (Watson, l. c. p. 229).-Utah, 1871, 1872, Watson's Report; South Park, Colorado, 1873, Wolf (285); Gray's Peak (287); Sanoita Valley, Arizona, at 6,500 feet elevation, August, 1874, Rothrock (626).

Orthocarpus luteus, Nutt. (Watson, l. c. p. 231).-Twin Lakes, Colorado, August, 1873, Wolf (319).

Orthocarpus Tolmiei, Hook. \& Arn. (Watson, l. c. p. 230).-Utah, 1871, 1872, Watson's Report.

Cordylanthus Wrightir, Gray (Watson, l.c. p. 459).-Mesa south of Black River, Arizona, at 5,700 feet elevation, September, 1874, Rothrock (795).

Cordylanthus laxiflorus, Gray (Watson, $l$. c. p. 232).-." Point of Mountain", Arizona, September, 1874, Rothrock (721).

Pedicularis Grgenlandica, Retz. (Watson, l. c. p. 233).-South Park, Colorado, 1873, Wolf (281).

Pedicularis crenulata, Benth--Pubescent; stems erect, simple, 6 to 12 inches high; leaves all linear-oblong, obtuse, doubly crenate, 9 to 15 lines long; spikes short, densely flowered; calyx cleft on the upper side, minutely 2-3-toothed; galea hooded, subincurved, 2-toothed under the " apex.-South Park, Colorado, J873, Wolf $(283,851)$.

Pedicularis Sudetica, Willd.-Erect, simple, 8 to 12 inches high, glabrous except the spike; lower leaves pinnately-parted, narrowly lanceolate in outline; segments lanceolate, crenate, or subincised-serrate; upper ones pinnatifid; spike short, densely hirsute-woolly; calyx 5 -toothed, teeth entire or the lateral denticulate; galea of the reddish-purple corolla arcuate, scarcely hooded, shortly and broadly subrostrate, 2 -toothed under the apex. Var. with smoother spikes and no teeth on the tip of the galea.- South Park, Colorado, 1873, Wolf (279); Mogollon Mesa, Arizona, 187?, Loew (280).

Pedicularis procera, Gray - Stem $1 \frac{1}{2}$ to 3 feet high, stout, leafy, bearing above a dense-flowered, softly pubescent spike 9 to 18 inches long; leaves glabrous, pinnately-parted; segments lanceolate, laciniate-pinnatifid, lobes serrate or incised, radical ones 1 to $1 \frac{1}{2}$ feet long; bracts elongated, 
linear from an ovate-lanceolate base, lower ones pectinate-pinnatifid, exceeding the flowers; calyx about equally 5-cleft, lobes lanceolate, entire, about half shorter than the tube; corolla 1 inch or more long, striate, dirty-green; galea hooded at the apex, not beaked, truncate, 2-toothed, scarcely equalling the 3-lobed lip-Mosquito Pass, Colorado, 1873, Wolf (284); Willow Spring, Arizona, July, 1874, Rothrock (212); Mount Graham, August (45 a).

Pridicularis racemosa, Dougl. (Watson, l.c. p. 234).-Twin Lakes, Colorado, 1873, Wolf (320).

Pedicularis Parryi, Gray.-Very smooth, except the ciliated bracts; stem 6 to 12 inches high, more or less bracted; leaves linear-lanceolate, pectinate-pinnatifid, petioled, cauline ones small, segments linear, acute, about 3 lines long, cartilaginous-serrate; bracts small, trifid; flowers numerous, short-pedicelled, in a narrow spike 1 to 2 inches long, dirtyyellow; calyx membranaceous, marked with 5 striæ, at length subinflated; teeth 5, short, lanceolate, very entire, lanuginose within; galea narrow, apex incurved, gradually produced into a longish, emarginate beak, which is sometimes decurved, much surpassing the lower lip; filaments very smooth — South Park, Colorado, July, 1873, Wolf (282).

\section{OROBANCHACEA.}

Aphyllon fasciculatum, Gray.-Colorado. Attached by its rootlets to those of Artemisia frigida, Willd.

Aphyllon multiflorum, Gray (A. erianthera, Engelm. Proc. Amer. Acad. vii, p. 372).-Low, stem 1-3' high; lower flowers pedicellate; flowers purplish, $8^{\prime \prime}$ long; calyx-lobes linear, acute, $6^{\prime \prime}$ long; anthers very woolly.Utah.

\section{BIGNONIACE E.}

Martynia proboscidea, Glox-—San Francisco Mountains, Arizona.

Martynia, probably violacea, Engelm.-Too poor to determine.Rock Creek Cañon, Arizona (313).

Chilopsis* saligna, Don (C. linearis, DC. Prod. ix, 227, and of Bot.

"Chilopsis, Dun._ "Calyx membranaceons, ovate in the bucl, irregnlarly bilabiate, often split deeper on one side. Corolla funnelform, ventricose above, with an ample bilabiately 5-lobed spreading limb; the rounded lobes erose and undulate. Stamens 4 and a sterile filament; cells of the anther 
Mex. Bound. 1. 110).-Small tree, six inches in diameter at the base, 20 feet ligh, with many slender branches; wood resembling willow; leaves : 6 ' long, 2-4" wide, slightly falcate, entire, and the older ones somewhat sticky. The white or purple flowers $18^{\prime \prime}$ long in a terminal raceme; capsules linear, 6-8' long.-Camp Goodwin, Arizona (344), where, from its appearance and habitat, it is known as Desert Willow.

\section{ACANTHACEAE.}

Calophanes* Decumbens, Gray, Syn. Fl. 1, 325 (C. oblongifolia, Torr. Bot. Mex. Bound. p. 123, not Don).-Procumbent or ascending; herbaceous, except at base; leaves and axillary clusters of flowers secund; stem pubescent, upper surfaces of the leaves slightly so, under surfaces almost smooth, margins and midribs (below) a little hispid; corolla light blue?, funnel-shaped, tube 7-8" long, border $6^{\prime \prime}$ in diameter, lobes ovate, calyxlobes linear, setaceous, equal in length to the tube of the corolla, but shorter than the lanceolate bracts; seeds four.-Sanoita Valley, Southern Arizona, at 5,500 feet altitude (637)

Ruellia† tuberosa, Linn., var. occidentalis, Gray (Syn. Fl. 1, p. 325).-A pubescent herb, $3^{\circ}$ high, branched; leaves oval, somewhat firm, slightly hairy, tapering into a margined petiole; margins crenate or somewhat undulate; terminal panicle naked; flowers blue or purple, 1-2' long; tube $6-8^{\prime \prime}$ long, suddenly expanded into a wide throat; lobes roundish; stamens and style included; calyx-lobes linear, setaceous pubescent; capsule somewhat hairy, lanceolate or club-shaped, 8-16-seeded.-Cienega, Southern Arizona (560). Probably a good species.

naked and diverging. Capsule long and linear, terete, resembling that of Cafalpa, 2-celled, with the at length loose narrow partition contrary to the valves. Seeds oblong, thin, with the wing at each end dissected into a woolly or finely bristly tuft. Cotyledons 2-lobed."-Fl. Cal. 1, p. 587.

- Calopinanes, Don.-Calyx deeply 5-cleft; lobes setaceo-acuminate. Corolla-tube straight, narrowly cylindrical, somewhat dilated above; limb somewhat spreading and slightly 2-labiate, the 5 obovate lobes somewhat unequal. Stamens 4, perfect, slightly didynamons, inserted in pairs and connate below; included; anthers fixed by the back, oblong, the cells nearly parallel, a little mucronate at base. Style slender, cnrved above, hispid; ovules 2 in either eell. Capsule oblong-linear, contracted at 1 he base into a solid stipe, somewhat thickened abore, 2-4-seeded. Seeds orbicular, flat, borne on acnte placental processes.-Herbs, with woody bases, erect or procumbent, the leaves entire, opposite or often fascicled at the axils. The blue or pale flowers sub-sessile in the axils, few or many in a cluster, rarely short cуmose--ВеNтн. \& Ноок. I have kept this genus apart from Ruellia solely in deference to Bentham and Hooker.

†RUkr.tsa, Linn.-Like Calophames, except that the cells of the capsule bave each more than two serels, aud the ant hers are pointless below. 
Sirhonogyossa* LONGIFlora, Gray (Syn. Fl. 1, p 328)--Low, uniformly pubescent; leaves opposite, on short petioles, rhombic-ovate to lanceolate, thickish, 6-18" long; petiole 2-4" long; flowers yellowish-white; tube very slender, 8-12" long; stamens included; filaments membranaceous, a little longer than the anther; style very slender, much exceeding the flower, evidently 2-lipped; capsule dark brown, oval; seeds with the margin dis tinctly notched at the point of attachment.-Specimen was a mere fragment. Cienega, Southern Arizona (573).

Anisacanthus $\dagger$ pumilus, Nees (Drejera puberula, Torr. in Bot. Mex. Bound. p. 121; and Watson in 1874 Report, p. 13).-_"The pubescent branches distichous; leaves oblong-lanceolate or linear-lanceolate, pubernlent, short-petioled; the short leafy spikes axillary and terminal; the deeply 5-cleft calyx glandular-pubescent, the lobes linear-subulate; tube of the corolla narrow, many times longer than the calyx, inferior lip 3-parted, the lobes lanceolate-linear. Corolla $18^{\prime \prime}$ long, purplish-red Capsule smooth, 6-7" long, the upper half rhombic-ovate and seminiferous, the lower attenuated to a narrow stipe and empty. Shrub $4-8^{\circ}$ high."-Arizona. I have not seen the specimen, and have quoted largely from Bot. Mex. Bound. $l$ c.

Dicliptera $\ddagger$ Resupinata, Juss.-Stem erect, simple or much branched from a woody base; leaves opposite, glabrous to slightly pubescent, lanceolate to oblong, on a slender petiole, which is $3-6^{\prime \prime}$ long; inflorescence in a compound cymose umbel, with the common peduncle as long as or exceed-

* Siphoxoglossa, Erst.-Culyx 4-5-parted, the short segments narrow. Corolla-tube elougated, narrowly eylindrical, slightly or not at all dilated above; limb spreading, 2-lipped, the posterior lip interior, entire or 2-cleft, the other widely spreading, 3-cleft. Stanens 2, affixed near the apex of the tube; anthers 2-celled, with one cell higher tban the other; cells somewbat sharp pointed or spurred; staminodia none. Style filiform, the obtuse apex with 2 short lobes; 2 ovules in either cell. Capsule oblong, contracted at the base into a solid stipe. Seeds 4 , or by abortion fewer, suborbicular, compressed marginate, tubercnlate-rugose; placental processes obtuse.-Sub-shrubby [or herbaceous]. low, spreading, pubescent. Leaves ovate, entire. The subsessile flowers solitary in the axils. The linear bracts short, BитTII. \& НоOК.

+ Anisacanthus, Nees.-Shrub, posterior lobes of the imbricated corolla interior in the bud. Oval capsule elevated on a conspicuous stipe; ovules two in each cell, attached to the placental processes by the edge; seeds flat; stamens two ; anther cells two. equal ; rudiments none.

†Dichiptkra, Juss.- "Bracts a pair, valvately inclosing 1-3 flower-buds. Corolla tubular, bilabiate; the upper lip interior in the bud, flat or concave, emarginate o: entire; the lower spreading, toothed or lobed. Stamens 2: anthers with 2 cells, one bigher than the other, both pointless. Capsule short, flattened contrary to the partition, 4-seeded, the base stedless and stalk-like, the strong processes that bear the seeds curving upward and becoming hook-like at debiscence. Seeds flat.-Mostly herbs: with 6-angled stems, broadish and petioled leaves, and eit ber scattered or elustered flowers: mainly tropical, two or three species reaching the United States."-Fl. Cal vol. 1, p. 589. 
ing the special peduncle; bracts ovate-cordate, 2-5-flowered (some of them aborting); flowers $8-10^{\prime \prime}$ long, light purple, lower lip 3-toothed, upper lip ovate. Very variable in foliage and inflorescence.-Cienega, Southern Arizona. Besides this form, I have another resembling it in all respects, save that the inflorescence is more simple; two or three peduncles, $1-1 \frac{1}{2}^{\prime}$ long, rising from the axils at a node, and each terminated by a single pair of the usual ovate-cordate bracts. This difference is constant in my specimen (571), and might entitle it to a specific rank were it not for the variability in just this respect in $D$. resupinata. Also from Cienega, Arizona.

Tetramerium* hispidum, Nees ( $T$. nervosum, Nees, "var. hispidum foliis ovato-oblongis obtusiusculis vel acutis (non acuminatis)", Torr. Bot. Mex. Bound. p. 125).-Bracts conspicuously ciliate, oblong; flower yellowish-white (with the anthers visible through a lobe of the lower lip as a brown spot), 5-7" long.-In the Sanoita Valley, Arizona (686), near (probably) where the specimens described in Bot. Mex. Bound. l. c. were obtained.

\section{VERBENACEÆ.}

Lipfia Wrightir, Gray (Torr. in Bot. Mex. Bound. p. 126). (Aloysia scorodonoides, H. B. K. Nov. Gen. et Sp. 2, p. 260, is a different plant.) -Shrub, 2-4 feet high, much branched; leares oral, 3-8"long, thickish, deeply crenate, rugose above and white tomentose-pubescent below, abruptly tapering to a short petiole ; hairy spikes 1-1 $\frac{1^{\prime}}{2}$ long, paniculate; flowers white, 1-2" long, tubular, with a spreading, subregular border; stamens subequal, short. Calyx with long, spreading, white hairs. The mature fruit readily separates into two nutlets.-Mount Turnbull (170 a, Loew), and elsewhere in Arizona.

Lippia nodiflora, Michx.-Herbaceous or somewhat woody; stem creeping, rooting at the joints; peduncles long, slender; entire plant finely pubescent; leaves oblanceolate or cuneate, serrate toward the apex; white

" Tetramerium, Nees,-Herbaceous bracts narrow, more or less convate in pairs, including single flowers witb or without rudiments of others. Calyx short, 5-cleft; lobes linear, delicate. Tube of corolla slunder, cyliudrical ; limb 2-lipped, the hinder lip interior, obovate or oblong, erect, entire, concave, the lower lip 3-parted, with the oblong lobes flat, spreading, the middle one outside. Stamens 2, inserted in the throat and sub-equalling the corolla ; anthers 2-celled, the cqual, pointless, parallel cells separated by a broadish connective; staminodia 0 . Disk rather thick. Siyle filiform, the stigmatose subclavate apex with 2 very short lobes; 2 ovules in either cell. Capsule ovate-oblong, tapering into a solid stipe at base; placenta during dehiscence torn loose from the valves. Seeds 4, or fewer by abortion, plano-conpressed, sub-orbicular.-Pubescent herbs, often slurubby at base. Leaves entire. Flowers rather surall, pallid.-BENTII. \& Ноок. 
flowers in a dense head on a peduncle much longer than the leaves; calyx flattened, "2-cleft, 2-keeled; fruit corky and not readily separating into the 2 nutlets."-New Mexico, Loew.

Verbena hastata, L.-Utah.

Verbena bracteosa, Michaux.-Utah.

Verbena Aubletia, L.-Arizona; New Mexico, at Santa Fé (12); also in Rocky Cañon, Arizona.

\section{LABIAT E.}

By Prof. T. C. Porter.

Mentha viridis, Linn.-Camp Bowie, Arizona, at 5,300 feet elevation, August, 1874, Rothrock (491). Introduced?

Mentha Canadensis, Linn.-Utah, 1871, 1872, Watson's Report; Zuñi, N. Mex, at 6,500 feet elevation, July, 1874, Rothrock (168); Sanoita Valley, Arizona, at 4,350 feet elevation, September, 1874, Rothrock (687).Var. glabrata, Benth., Upper Arkansas, Colorado, 1873, Wolf (778).

Lrcopus sinuatus, Ell.-Utah, 1871, 1872, Watson's Report. An imperfect specimen of a Lycopus, collected in San Luis Valley, Colorado, September, 1873, by Professor Wolf (782), appears to be L.lucidus, Turcz., var. Americanus, Gray (Proc. Am. Acad. 8, p. 286)

Monardella odoratissima, Benth. (Watson, Bot. King, p. 235).Nevada and Utah, 1871, 1872, Watson's Report.

Hedeoma hyssopifolia, Gray (Proc. Am. Acad. 11, p. 96).-Nearly glabrous ; stems from a perennial branching caudex, slender, scarcely a foot high; leaves crowded, nerved, the main ones linear-lanceolate, $\frac{1}{2}$ to $\frac{3}{4}$ of an inch long and a line wide, the parallel veins running toward the apex, the upper gradually reduced until shorter than the calyx, the lowest much shorter and broader, with strong and more diverging nerves beneath; whorls loosely 3 - to 5-flowered; calyx narrow-tubular, slightly hairy, the setaceous teeth incurved, the lower ones exceeding the upper; corolla 7 to 8 lines long and twice the length of the calyx; upper lip 2-lobed-Mount Graham, Arizona, at 9,000 feet elevation, August, 1874, Rothrock (418); Arizona, 1873, Loew (780).-Plate XVII. Natural size. Fig. 1. Flower, enlarged 5 diameters. Fig. 2. Longitudinal section through flower, 5 
diameters. Fig. 3. Calyx, 5 diameters. Fig. 4 Corolla opened longitudinally, showing nutlets, style, and the two perfect and two rudimentary stamens, 5 diameters.

Hedeoma dentata, Tort. (Bot. Bound. Survey, p. 130).-Annual; much branched from the base; branches erect, scarcely 1 foot high, slender, pubescent; leaves oblong-lanceolate, about 5 lines in length, acute, tapering into a short petiole, with 3 to 4 acute teeth on each margin, the veins underneath prominent and thicker at the extremity; whorls usually 6 -flowered; teeth of the slightly gibbous calyx unequal, from a broad, subulate base, those of the lower nearly twice as long as those of the upper lip; corolla almost twice as long as the calyx, the upper lip emarginate, the lower 3-lobed, the middle lobe notched.-Camp Grant, Ariz., at 4,753 feet elevation, August, 1874, Rothrock (458), and in Sanoita Valley, at 6,300 feet elevation (628).

Salvia lakceiolata, Willd-Hoary pubescent; stems 3 to 15 inches high, herbaceous, ascending, branched ; leaves lanceolate or oblong linear, 1 to 2 inches long, rather obtuse or acuminate, narrowed at the base into a long, slender petiole, sparsely and obtusely serrulate in the middle; bracts subulate, a little longer than the short pedicels; raceme simple, 2 to 4 inches long; whorls about 2-flowered, all remote; calyx tubular, striate, puberulent, enlarged in fruit, inflated at the base, teeth acute; corolla blue, a little longer than the calyx, 4 lines long; style short-bearded.-Arizona, 1873, Loew (786); Mount Graham, at ",250 feet elevation (407), Camp Apache, at 5,000 feet elevation (813), and Canp Crittenden, at 5,000 feet elevation (678), 1874, Rothrock.

Audibertia incana, Benth. (Watson, Bot. King, p. 235).-Nevada, 1871, 1872, Watson's Report.

Monarda fistulosa, Linn-Willow Spring, Arizona, at 7,195 feet elevation, July, 1874, Rothrock (159 a, 242).

Monarda citriodora, Cervantes ( $M$. aristata, Nutt.).-Canescent; a foot high, with numerous spreading branches; leaves linear or oblonglanceolate, narrowed at the base, sharply and remotely serrate; floral ones and outer bracts sessile, somewhat colored, tipped with a long, subulate awn; whorls many-flowered, compact, remote; calyx striate, pubescent, 
bearded in the throat; teeth nearly equal, long, subulate, pilose, penicillate at the apex; tube of the corolla scarcely longer than the calyx-teeth.-Fort Wingate, N. Mex., 1873, Loew (781, 789); Arizona, at Camp Grant, elevation 4,753 feet, July (385); Sanoita Valley, August; Mount Graham, at 9,000 feet elevation, September, 1874, Rothrock (729).

Lophanthus urticerfolius, Benth. (Watson, Bot. King, p. 236).Utah, 1871, 1872, Watson's Report; Mount Graham, at 9,000 feet elevation, September, 1874, Rothrock (746).

Nepeta Cataria, Linn.-Utah, 1871, 1872, Watson's Report. Introduced.

Dracocephalum Parviflorum, Nutt. (Gray's Man. p. 353).-Twin Lakes, Colorado, 1873, Wolf (784).

Salazaria Mexicana, Torr. (Watson, l. c. p. 237).-Nevada, 1871, 1872, Watson's Report.

Scutellaria antirrhinoides, Benth. ( $S$. resinosa of Watson, Bot. King, p. 237, not Torr.).-Nevada, 1871, 1872, Watson's Report

Scutellaria Resinosa, Torr (DC. Prod.12, p. 428).-Glandular-pubescent; stems low, erect, much branched; leaves short-petioled, broadly ovate, obtuse, very entire, rounded at base, floral ones similar; flowers axillary, opposite, secund; corolla villous, more than four times longer than the calyx.-Denver, Colo., June, 1873, Wolf (780). Leaves green on both sides, prominently veined beneath, finely pubescent or glabrate, the hairs tipped with minute resinous glands, the lowest shorter and broader, more rounded at base, but never cordate, the upper 5 to 9 lines long, varying from ovate to lance-ovate, more or less attenuate at base; corolla blue, densely villous, erect or ascending, the tube often curved below.

Scutellaria galericulata, Linn. (Gray's Man. p. 357).-San Luis Valley, Colorado, September, 1873, Wolf (779, 781); Willow Spring, Arizona, at 7,195 feet elevation, July, 1874, Rothrock (245).

Brunella vulgaris, Linn.-Summit Spring, Arizona, at 8,000 feet elevation, July, 1874, and Sanoita Valley, August, 1874, at 5,500 feet elevation, Rothrock $(198,650)$.

Stachys coccinea, Jacq. (DC. Prod. 12, p. 467).-Herbaceous, erect, 
softly pubescent, villous or hispid ; leaves petioled, ovate-lanceolate, obtuse or acute, crenate, cordate at base; racemes elongated; whorls 6-flowered, all distant; corolla pubescent, nearly thrice longer than the calyx, the tube much exserted.-Camp Grant, Arizona, at 4,753 feet elevation, and Camp Bowie, at 5,300 feet elevation, August, 1874, Rothrock (386, 461, 483). Stems 1 to 2 feet high; hairs clothing the leaves and stems soft and short, or more rigirl, especially on the angles of the stem, or alnost wanting ; leaves deeply or shortly crenate, larger ones sometimes 2 or even 3 inches long; whorls of flowers few, very distant or numerous in a short or long raceme; calyx sessile or pedicellate, with a tube 2 to 3 lines long, and short or long teeth, which are either subspinescent, erect, or somewhat sprearling, or long subulate-acuminate; corolla varying from barely 9 lines to more than an inch in length.

Stachys albens, Gray (Proc. Am. Acad. 7, p. 387).-Tall, 3 to 5 feet high and rather strict, soft-tomentose throughout, with white or whitish wool, leafy; leaves oblong or ovate and mostly cordate, obtuse, crenate, 2 to 3 inches long, the lower short-petioled, the upper nearly sessile; flowers several or numerous in the capitate clusters, which mostly exceed the floral leaves, and form an interrupted, at length elongated, virgate spike from 3 to 9 inches long; calyx turbinate-campanulate, its teeth triangular and awnpointed; corolla white, with purple dots on the lower lip, glabrous, except the villous beard on the back of the upper lip.-Arizona, 1871, 1872, Watson's Report.

Stachys Rothrockit, Gray (Proc. Am. Acad. 12, p. 82).-A span high, branching from the base, covered with a coat of villous wool; root apparently perennial; leaves all sessile, lanceolate, more or less obtuse, sub-entire, about 1 inch long, the upper floral ones not surpassing the flowers; whorls usually 3 -flowered, in a crowded spike ; calyx sessile. subcanıanulate, teeth subovate, awnless; corolla 4 to 5 lines long, tube scarcely longer than the calyx; upper lip villous on the outside.-Zuñi Village, N. Mex., at 6,500 feet elevation, July, 1874, Rothrock (177).

Stachys Palustris, Linn. (Gray's Man. p. 358).-Trout Creek and San Luis Valley, Colorado, 1873, Wolf (783, 785); Willow Spring, Arizona, at 7,195 feet elevation, July, 1874, Rothrock (240). 
Lamium amplexicaule, Linn.-Mosquito Pass, Colorado, July, 1873, Wolf (777). Introduced.

Trichostema Arizonicum, Gray (Proc. Am. Acad. 8, p. 371).-Puberulent ; much branched, from a perennial, woody caudex; branches mostly simple, $\frac{1}{2}$ to $1 \frac{1}{2}$ feet high; leaves oval and ovate, short-petioled, floral leaves small; bracts minute; peduncles racemose, about 1 inch long, slender, twice or thrice shorter than the 3- to 5-flowered cyme; calyx campanulate, slightly unequal, but equally 5-cleft; lobes ovate-lanceolate, equalling the tube of the corolla; lobes of the corolla spatulate-oblong, declined; filaments not quite an inch long.-Sanoita Valley, Southern Arizona, at 6,500 feet elevation, August, 1874, Rothrock (621).

Tetraclea* Coulteri, Gray (Sillim. Journ. 2d s. 16, p. 98).-Herbaceous, from a suffruticose base, puberulent, branches erect; leaves opposite, petioled, ovate, subdentate, floral ones similar but smaller; whorls loose, axillary; cymes peduncled, usually 3 -flowered; flowers short-pedicelled, white, becoming yellowish after anthesis.-Cienega, Ariz., August, 1874, Rothrock (558).

Teucrium Canadense, Linn.-Arizona, 1873, Loew.

\section{PLANTAGINE $\mathrm{E}$.}

Plantago Patagonica, Jacq., var. gnaphaliomes, Gray.-Denver.

Plantago major, L.-Cienega, Southern Arizona (555).

NYCTAGINEA.

Mirabilis multiflora, Gray.-Common throughout Arizona, New Mexico, and open grounds of Southern and Central Colorado.

Mirabilis longiflora, L.-Cottonwood, Arizona, at 4,500 feet (359).

Oxybaphus nyctagineus, Sweet, var. Latifolius, Gray.-Differing from the type in having the involucre and younger branches hairy, the leaves

"Tetraclea, Gray (Benth. \& Hook. Gen. 2, p. 1220)-Calyx broadly campanulate, 10-nerved, deeply 5-cleft; lobes nearly equal. Tube of the corolla exserted, slender, cylindrical; limb spreading, 5-cleft, lobes oboval-oblong, nearly equal. Stamens 4, didynamons, with the anterior pair longer, jucurved-ascending, much exserted; anthers 2-celled, cells distinct, parallel. Disk equal, short. Ovary shortly 4-lobed at the apex; stjle 2-cleft at the apex; lobes subulate, vearly equal. Nntlets obovoid, hard, reticulate-rugose, attuched by a broad, keeled areola, extended beyond tho middle, leaving no gynophore when d. tach d. Seeds affixed lateraily.

$15 \mathrm{BOT}$ 
broader, subcordate at base, and quite membranaceous - Mount Graham, Arizona, at 9,250 feet altitude (423).

"Oxybaphus nyctagineus, Sweet, var. oblongifolius, Gray.-With small flowers and leaves. Nevada."-Watson.

Oxyвaphus hirsutus, Sweet, var-Leaves lanceolate-linear; stem glabrous or nearly so.-Willow Spring, Arizona, at 7,195 feet (206).

Oxybaphus angustifolius, Sweet-Colorado $(810,811,814)$, and Nevada and Arizona.

Oxybaphus coccineus, Torr--Erect, glabrous; leaves $2-4^{\prime}$ long, 1- $3^{\prime \prime}$ wide; inflorescence in a loose, terminal panicle; perianth 3-flowered, tinged with purple, pubescent; calyx 6-8" long, pubescent externally; stamens 5 , exserted; fruit with 5 corky wings, somewhat roughened.

Allionia incarnata, L-(324), Ash Creek, Arizona. $156 a$, collected by Loew in Arizona, and having the marginal teeth on the fruit quite glandlike, and comparing well with Palmer's specimen in 1875 from St. George, Utah, which I find Mr. Watson marks with a doubt. Besides this, I have 107 from Covero, New Mexico, in which the leaves are quite oval, obtuse, and veiny beneath, and the marginal wings of the fruit developed into strong, uncinate, glandular teeth, much larger than the central ones, which they conceal. This may be a distinct species. My specimens are quite variable, some having 4, 5, and even 6 stamens, either included or exserted. The Expedition has it also from Nevada.

Abronia fragrans, Nutt-Colorado $(808,812,813)$, and New Mexico (127), where, in the evening, it was the most fragrant of flowers.

Abronia turbinata, Torr-Gila Valley, Arizona $(340,765)$

Abronia villosa, Watson (American Naturalist, vii, p. 302).--"Covered throughout with a more or less dense villous subglandular spreading pubescence; stems weak and slender; leaves small, $1-1$ inch long, oblong or ovate, obtuse or acutish, attenuate into the slender petiole; heads 5-.0flowered; involucral scales narrowly lanceolate, long-acuminate, 3-4 lines long; flowers pink, the lobes obcordate, with a deep sinus; fruit with a firm body, strongly reticulate-pitted, the $3-5$ broad wings, consisting of a simple lamina, usually truncate above. Nearest to A. umbeldata." - (Watson in Wheeler's Preliminary Report, 1874, p. 15.) I have not seen the speci- 
men, and have therefore been obliged to quote the description entirePlate XXIII. Fig. 1. Branch, natural size. Fig. 2. Flower, laid open, enlarged about 5 diameters. Fig. 3. Cross-section of fruit.

Abronia cycloptera, Gray.-Southern Colorado $(809,815)$ and deserts of New Mexico.

BoerhaAvia* Wrightit, Gray (Amer. Jour. Sci. 2, 15, 322).-Arizona. Erect, branching, viscidly glandular-pubescent, especially above; leaves petioled (or sessile above), lanceolate; inflorescence in a loose, branching panicle; bracts purplish, 3 to each flower, fimbriate ciliate on the margin; calyx border spreading, salver-shaped; stamens 2 ; fruit obovate, 4-angled or ribbed, somewhat wrinkled, roughened between the angles, 1-2" long.Cienega, Arizona, at an altitude of 3,500 feet (570). (157 a, Loew, Arizona )

BoerhaAvia ERECTA, L.-Erect, "branching from the base, swollen at the nodes," glabrous or nearly so ; leaves petioled lanceolate to oval, dark glandular-dotted and slightly pubescent; panicle disposed in 3-5-flowered clusters; stamens 2. The narrowly obconical fruit evidently truncate, distinctly 5-angled, "flowers small, purple".-Cienega, Arizona (588), along with the preceding.

Buerhaavia Grahami, Gray.-Erect (not climbing, but spreading over lower herbs), woody at base, herbaceous above and glabrous and glaucous; leaves $1-1 \frac{1}{4}^{\prime}$ long, nearly as wide, margin somewhat undulate, cordate at base; petioles 4-6" long; common peduncles axillary, much exceeding the leaves; special peduncles about six, 2-4" long, umbellate; scales of involucre 1-2 long, greenish, pruinose, perigonium black below, greenish and somewhat short pubescent above; pistils and stamens exserted; stigma capitate; fruit terete, glandular at the apex. Dr. Torrey, in Bot. Mex. Bound. p. 172, thinks this may. safely be assigned to B. scandens, L. So far as Choisy's description of it goes, DC. Prod. vol. 13, pars 2, p. 454, I can see no reason why it should not, and have simply described it under this name, because it has been so identified by my friend Dr. Gray.-Head of the "Cienega", Southern Arizona (590).

BuerhaAvia spicata, Choisy--Erect, annual, somewhat pubescent;

* BoemhaAvis, L.-See Appendix to vol. v, King's Report, p. 475. 
lower leaves ovate, often slightly cordate at base, upper ones lanceolate undulate on margin; inflorescence paniculate; racenes few-flowered, termimating the branches; stamens 3, exserted; fruit 5-angled or winged, clubshaped; flowering racemes short, but much elongated when in fruit (378 a, Arizona, Loew).

\section{PHYTOLACCEA}

Rivina* Levis, Linn.-Herbaceous above, sub-shrubby below, branching from the base; stem striate and with the leaves puberulent; leaves broadly ovate or ovate-cordate, on slender petioles half their length; flowers purplish; calyx-lobes ovate, as long as the four stamens; anthers oblong; filaments thickish; style 1-2" long, somewhat curved; stigma capitate, oblique, distinctly papillose.-In clefts of rocks, Southern Arizona (582).

\section{POLYGONACEA.}

By Prof. T. C. Porter.

Eriogonum alatum, Torr. (Sitgreaves's Rep. p. 168, t. 8).-Perennial; root stout and blackish; stem erect, 1 to 3 feet high, arising from a short, thick caudex, clothed with the remains of leaves, subflexuons, leafy: branches alternate, erect, paniculate; radical leaves spatulate or oblanceolate, 2 to 4 inches long, 3 to 5 lines wide, hirsute; peduncles terminal, in threes; flowers yellowish; involucre solitary, campanulate, 5-cleft; perigonia glabrous, segments equal; achenia 4 lines long, winged nearly to the base; wings broad, thin; seeds ovate, triangular-Colorado, 1873, Wolf (806); Willow Spring, Arizona, at 7,195 feet elevation, 1874, Rothrock (204).

Eriogonum Jamesir, Benth - Stems 5 to 12 inches high, cæspitose, from a branched, few-leaved, woody caudex; radical leaves spatulate-ovate or narrowly lanceolate, cauline in verticils of 3 to 5 , spatulate or oblong,

- Rivina, Plum.-Flowers bermapbrodite, 3-bracted; calyx 4-parted, the equal lobes sub. corolline. Corolla none. Stamens 4-8, sub-hypogynous, the 4 exterior alternate with the laciniæ of the calyx. F.laments filiform-subnlate. Authers ovate-cordate to narrowly oblong. One-celled ovary simple, with a single amphitropons ovule fixed by the base. The longish style sublateral; capitate stigma papillose; sub-globose berry at length dry. Seed vertical, sub-globose or ovoid, the testa crnstaceous; albumen central, mealy, surrounded by the ringulike embryo; radiclo descending; cotyledons membranaceous, exterior one larger and embracing the inner; sub-shrubby [or, as in my species, rather berbaceous, except at the slightly woody base]. Moquin, in DC. Prod, vol, 13, pars 2, p. 10. 
subsessile, white-tomentose beneath; eyme dichotomous, leafy; involucres in the forks or sessile on the branches, many-flowered, loosely silky-villous externally; segments obovate or spatulate; perigonia somewhat petal-like, white or whitish, the 3 interior segments often becoming longer-Upper Arkansas River, Colorado, 1873, Wolf (25); Camp Bowie, Arizona, August, 1874, Rothrock (473).

Eriogonum flavum, Nutt.-Perennial, canescent with a silky-woolly or hoary pubescence; stems scapiform, 3 to 6 inches high, from a thick, many-parted caudex; leaves spatulate or oblong-spatulate, becoming more or less glabrate above, radical ones crowded on the caudex, those of the involucre about equalling the 2 to 8 rays and of the same number; perigonia golden-yellow, 3 lines long, silky-villous on the outside, funnel-form at base, somewhat produced into a stipe; ovary hirsute at the apex.-South Park, Colorado, 1873, Wolf (26).--Var. Elatius, Watson, Twin Lakes, Colorado, August, 1873, Wolf (28); Arizona, 1873, Loew (153 a).

Eriogonum Cespitosum, Nutt. (Watson, Bot. King, p. 298).-Utah, and Halleck Station, Nevada, 1871, 1872, Watson's Report.

Eriogonum stellatum, Benth. (E. polyanthum, Benth.; Watson, $l$. c. p. 478).-Utah, 1871, 1872, Watson's Report.

Eriogonum heracleoides, Nutt. (Watson, l. c. p. 299).-Utah, 1871, 1872, Watson's Report.

Eriogonum umbeliatum, Torr. (Watson, l.c. p. 300).-Utah and Nevada, 1871, 18i2, Watson's Report; South Park, Colorado, 1873, Wolf (24).

Eriogonum ovalifolium, Nutt. (Watson, l. c. p. 301).-Northern Nevada, 1871, 1872, Watson's Report.

Eriogonum pauciflorum, Pursh.-Low, cæspitose; branches of the caudex very short and crowded; leaves linear or subspatulate, revolutemargined, attenuated into a petiole, at length nearly smooth; scape 4 to 6 inches high, bearing a single head; involucres 5 to 10 , turbinate-campanulate, 5-toothed; calyx white, glabrous, lobes oval; filaments pubescent below.-Torr. \& Gray, Rev. Eriog. Proc. Am. Acad. 8, p. 166.-Sulphur Springs, South Park, Colorado, August, 1873, Rothrock (27).

Eriogonum elatum, Dougl. (Watson, l. c. p. 302).-Nevada, 1871, 1872, Watson's Report (260). 
Ericgonum fasciculatum, Benth, var. polifolium, Gray (Watson, $l$. c. p. 302).-Nevada, 1871, 1872, Watson's Report.

Eriogonum corymiosum, Benth. (Watson, $l$. c. p. 303).-Arizona, 1871, 1872, Watson's Report.

Eriogonum microthecum, Nutt. (Watson, l. c. p. 303).-Utah, 1871, 1872, Watson's Report; also var. effusum, T. \& G., Arizona, and a form between var. confertiflonum, T. \& G., and var Fendlerianum, Benth., but with larger flowers than usual. Var. EFFusum, T. \& G., Upper Arkansas, Colorado, September, 1873, Wolf (22).

Ertogonum brevicaule, Nutt. (Watson, l. c. p. 304).-Utah, 1871, 1872, Watson's Report.

Eriogonum racemosum, Nutt. (Watson, l. c. p. 304).-Nevada and Utah, 1871, 1872, Watson's Report.

Eriogonum Wrigitit, Torr. (Watson, l. c. p. 305).-Sanoita Valley, Arizona, at 5,850 feet elevation, August, 1874, Rothrock (593), and Camp Grant, September (726).

Eriogonum gracile, Benth., var. effusum, T. \& G. (Watson, l.c. p. 305).-Nevada, 1871, 1872, Watson's Report.

Ertogonum Hermanis, Dur. \& Hilg. (Watson, l.c. p. 306).-Nevada, 1871, 1872, Watson's Report.

Eriogonum deflexum, Torr. (Watson, l. c. p. 30 3).-Arizona, 1871, 1872, Watson's Report.

Eriogonum cernuum, Nutt. (Watson, l. c. p. 308).-Twin Lakes, Colorado, July, 1873, Wolf (23). Var. Tenue, T. \& G., Nevada, 1871, 1872, Watson's Report.

Eriogonum trichopodum, Torr. (Watson, l. c. p. 309). - Ash Creek, Arizona, at 3,080 feet elevation, July, 1874, Rothrock (332).

Eriogonum inflatum, Torr. (Watson, l. c. p. 309).-Nevada and Arizona, 1871, 1872, Watson's Report.

Eriogonum Abertianum, Torr. (in Emory's Reconn. p. 151; Torr. \& Gray, Proc. Am. Acad. 8, p. 189).-Villous or loosely and softly pubescent, paniculately branched, 1 to $1 \frac{1}{2}$ feet high; branches ereet, often leafy almost to the apex; lower leaves ovate or subcordate, petioled, often undulate, those of the branches lanceolate or linear, subsessile; involucres more or 
less peduncled, many-flowered, deeply 5 - to 8-cleft, lobes foliaceous; calyx petaloid, glabrous, rose-colored, outer segments rounded, deeply cordate, becoming nearly 2 lines long, the inner linear-oblong, retuse-Cottonwood, Arizona, at 4,750 feet elevation, July, 1874, Rothrock (355).

Eriogonum pharnaceoides, Torr. (in Sitgreaves's Rep. p. 167, t. 11 ; Torr. \& Gray, l. c. p. 189).-Pubescent, very slender, effusely panicled, 1 foot high; internodes elongated; cauline leaves narrow-linear, sometimes revolute on the margins, hoary-tomentose beneath, becoming glabrous above, about 1 inch long; pedicels eapillary, smooth, 1 to 2 inches long; involucres 5- to 8-cleft, 8- to 12 -flowered, bracteoles filiform, villous; calyx petaloid, glabrous, white or rose-colored, outer segments broadly ovate, concave, in fruit bi-gibbous at base, the inner longer, oblong-linear, retuse; anthers dark.-Arizona, 1873, Loew (154a). Var.-Taller, 12 to 18 inches high, softly villous-pubescent throughout; branches much stouter and erect; lower leaves ovate-lanceolate; heads and flowers larger.-Sanoita Valley, at 5,850 feet elevation, September, 1874, Rothrock (664).

Chorizanthe Rigida, Torr. (Watson, $l$. c. p. 312).-Nevada or Arizona, 1871, 1872, Watson's Report.

Oxyria digrna, Campd. (Gray's Man. p. 419).-South Park, Colorado, July, 1873, Wolf (42).

Rumex occidentalis, Watson, Proc. Am. Acad. 12, p. 253 (R. longifolius, DC., Watson, l.c. 314).-Twin Lakes and San Luis Valley, Colorado, 1873, Wolf $(29,33)$.

Rumex salicifolius, Weinm. (Gray's Man. p. 420).-San Luis Valley, Colorado, 1873, Wolf (31). Var. with lance-ovate leaves and inner valves of the calyx larger and broad-cordate, Cienega, Arizona, August, 1874, Rothrock (564).

Polygonum aviculare, Linn.-Utah, I871, 1872, Watson's Report; Twin Lakes, Colorado, 1873, Wolf $(34,35)$.

Polygonum erectum, Linn.-Utah, 1871, 1872, Watson's Report; San Luis Valley, Colorado, 1873, Wolf (41).

Polygonem tenue, Michx., var. latifolium, Engelm.-Mount Graham, Arizona, at 9,000 feet elevation, 1874, Rothrock (758); Upper Arkansas, Colorado, 1873, Wolf (39). 
Polygonum imbricatum, Nutt. (Watson, in Am. Naturalist, 7, p. 665).Low, 1 to 8 inches high, slender, often diffusely branched, smooth; spikes short, dense; bracts loosely imbricated, linear or oblong, 2 to 4 lines long, with sometimes a narrow scarious margin, acute; sepals colored; stamens 3 or 5; styles one-third as long as the ovary; achenium glabrous - South Park, Colorado, July, 1873, Wolf (36).

Polygonum amphibium, Linn.-Utah, 1871, 1872, Watson's Report ; Colorado, 1873, Wolf (38).

Polygonum amphibium, L., var. Muhlenbergi, Meisn. in DC. Prod. 14, p. 116 -Camp Crittenden, Arizona, at 5,000 feet elevation, September, 1874, Rothrock (670). As in some of our Eastern specimens, the peduncles are glandular-scabrous.

Polygonum Persicaria, Linn.-Utah, 1871, 1872, Watson's Report. Introduced.

Polygonum nodoscm, Pers. (Meisner in DC. Prod. 14, p. 118)-Stem with the nodes much enlarged, 2 to 6 feet high; ochreæ loose, becoming glabrate, minutely ciliolate; leaves oblong or lanceolate, glandular-punctate beneath, the lowest short-oval or ovate, the highest linear, the middle ones 6 to 8 inches long and 1 to 2 wide, tapering into a long acumination; spikes racemose, linear, attenuated upward, loose, nodding, on glabrous peduncles; bractlets orate, acute, naked, longer than the pedicels; calyx flesh-colored or white, without glandular dots, slightly nerved, including the 6 stamens and 2-parted style; achenium lenticular, rarely triangular-San Luis Valley, Colorado, September, 1873, Wolf (40); Zuñi Village, New Mexico, at 6,500 feet elevation, July, 1874, Rothrock (160); Camp Lowell, Southern Arizona, August, 1874, Rothrock (702).

Polygoncm Hydropiper, Linn.-Sanoita Valley, Arizona, at 4,500 feet elevation, September, 1874, Rothrock (688). Introduced?

Polygonum viviparum, Linn.-South Park, Colorado, July, 1873, Wolf (43).

Polygonum Bistorta, Linn.--South Park, Colorado, July, 1873, Wolf (44). Var. obloxgifolium, Meisner, Willow Spring, Arizona, at 7,202 feet elevation, July, 1874, Rothrock (228). 


\section{AMARANTACEA.}

Gossypianthus* Rigidiklonus, Hook.-Stem prostrate, diffusely branched; cauline leaves secund, 2-4" long, 1-2" wide, acute, tapering to a rather broad base; flowers in axillary clusters; sepals membranous; filaments a little longer than the oblong anthers; stigma 2-lobed-Camp Bowie, Arizona, on limestone soil (507). Whole head of flowers densely covered with long cottony hairs, which, under a low-powered objective, are found to be transparent, jointed, and slightly swollen at the proximal side of the joint on account of the granular matter which accumulates there.

Alternanthera lanuginosa, Torr--Arizona (557). Apparently an excessively variable plant, so far as my imperfect specimens enable me to decide.

Nitrophila occidentalis, Watson (Banalia, Moq.).-Nevada.

Gomphrena nitida.-Erect, 6-14' high, branching from the axils; branches sometimes nearly as long as the main stem; stem and branches somewhat silky-hairy; leaves oblong-spatulate, 1-3' long, 4-8" wide, obtuse, mucronulate, cinereous, somewhat silky (younger ones densely so, and under an inch objective the hairs are seen to be beautifully jointed); heads sessile or nearly so, pearly-white (no trace of red), subtended by two (or more) large leaves; bracts membranous, usually somewhat laceratetoothed or crested on the back, broadly lanceolate, tapering into a very acute point; sepals very acute, membranous, abundantly hairy below and outside, somewhat shorter than the bracts; stamineal tube united to the top, middle lobe of the filament nearly obsolete, anthers oblong; style threefourths as long as the tube-Chiricahua Mountains, in Southern Arizona, on rocky knolls (520). The hair on the back of the sepals is (under a moderate power) seen to be quite long comparatively, and with the peculiar

* Gossypinthus, Hook.-Flowers hermaphrodite [2-3-bracted]. Calyx of 5 erect, subequal, very villose sepals. Stamens 5, free. Filaments subulate. Anthers unilocular, ovate. Single-celled ovary with one ovule. Style very short, roundish. Stigma emarginate, 2-3-lobed. Single-seeded utricle ovate, ralveless, included in the calyx. Seed vertical, ovate-lenticular, sub-reniform ; testa crustaceous. Embryo coiled around the central, farinaceous albumen; radicle ascending.-North American perenuial herbs, with procumbent, flexuose, woolly stems. Radical leaves petioled or sub-sessile, obovate or elongated-spathulate, rigid, sub-coriaceous; cauline opposite, sessile, much smaller, ovate, entire, more or less silky-woolly. Flowers axillary, densely aggregated, covered with copions flexuose wool, the deciduoue, delicate bracts keeled and concave-Moquin, DC. Prod. 13, pars 2, p. 337. 
twist of the cotton fibre, though, of course, too seant and short to be utilized. I am indebted to Mr. Watson for the following statement:

"It is the same as 1751 Wright, 946 and 1013 Thurber, 191 Wislizenus; also collected by Coulter and Berlandier. It is G. globosa, var. albiflora, Moq. in Bot. Mex. Bound. It is (without critical comparison), however, very much nearer $G$. decumbens, but has acuter bracts."

I am led to regard it as distinct from globosa, var. albiflora (which is "G. eriopoda, Gillies in Herb. Hook"), and certainly it is not G. decumbens, as in the latter only the interior sepals are silky, and the outer ones are obtuse, whereas in my specimens all are silky and acute.

Frelichia* Floridana, Moq.-Cinereous-tomentose or woolly, erect, $1-3^{\circ}$ high. Stem leafy below, nearly naked above; radical leaves lanceolate, obtuse, on rather long petioles; inflorescence in racemose spikes $6-12^{\prime \prime}$ long, and covered with a fulvous wool ; bracts dark, shorter than the calyx, which is woolly when young and hardens with age, becoming flattened, cristate and tuberculate at the base.-Camp Bowie, Arizona (488).

Amarantus fimbriata, Benth. (Sarratia Berlandicri, var. fimbriata, Torr. in Bot Mex. Bound. p 179. Amblogyne fimbriata, Gray, Proc. Amer. $\Lambda$ cad. v, p. 168).- "Stem and branches virgate; leaves linear-lanceolate, the globose glomerules sessile in the axils of the leaves, and in nearly leafless spikes above, approximate or crowded, the pointless bracts shorter than the calyx; sepals of the male flowers obtuse, of the female connate, sub. equal, narrowed at the base, flabelliform-cuneate, at the apex dentatefimbriate, widely spreading in fruit. Utricle circumcissile."-Nevada and Arizona.

Amarantus Torbeyi, Benth. (Sarratia Berlandieri, cum var. emarginata, Torr. l. c. Amblogyne Torreyi, Gray, Proc. Amer. Acad. v, p. 169).- "Diœcious, leaves ovate-oblong or oblong-lanceolate; glomerules paniculatespiked and axillary; bracts and sepals of the male flowers cuspidateacuminate. Sepals of the female flowers united below, equal, obovate-

"Freuchia, Mœnch.-" Flowers perfect, 3-bracted. Calyx tnbular, 5-cleft, indurated and spioycrested in fruit. Stamens 5, united into a long tube. Sterile filaments entire, anthers seseile. Stigma capitate or many-cleft. Utricle indehiscent, 1-seeded, included in the calyx. Seed vertical. Radicle ascending. Woolly or hairy annuals. [My specimens appen to bare a biennial or perennial root.] Leaves opposite. Spikes opposite, and terminating the naked peduncle-like summit of the stem."Chapmau's Flora of the Southern United States, p. 383. 
spatulate, the single nerve simple or slightly pinnately branched, apex round, entire, retuse or emarginate. Utricle circumcissile."-San Franciseo Mountains, Arizona. Not having access to specimens, I have quoted the description of this and the preceding species mainly from Gray, $l$. $c$.

Amarantus (Amblogyne) Palmeri, Watson (Proc. Amer. Acad. xii, p. 274).-Dicecious, erect, branching, smooth or nearly so; leaves oblongovate or rhombic-ovate, somewhat shorter than the slender petioles, entire or undulate, the upper ones sometimes linear-lanceolate; flowers in axillary clusters or elongated leafy spikes; male flowers with sepals one-nerved, acute, nearly equal, slightly exceeding the stamens; anthers introrse, fixed in a versatile way to the short filament; cells somewhat diverging below; bracts membranaceous, oval, and with a long awn-like tip, exceeding the calyx; female flowers with sepals distinct or nearly so, membranaceous, unequal-i.e., two larger and conspicuously tipped with an awn-like point, the others oblong, obtuse, retuse, entire, or somewhat dentate-fimbriate; stigmas 2 or 3 ; bracts much longer than the flowers, terminating in a stout, somewhat recurved, awn.-Camp Grant, Arizona (379).

Amarantus Wrighti, Watson (Proc. Amer. Acad. xii, p. 275).Smooth or nearly so, erect, simple or branching; leaves lanceolate to oblong, obtuse, 4-8" long, equalling the petioles; leafy spikes compound, short branchlets (of spike) zigzag, very slightly margined; sepals of fertile flower equal, obtuse, thickened, and somewhat gibbous at base, a little exceeding the utricle; stigmas 3 ; seeds black or brown, orbicular; subulate bracts rigid.-Valley of the Upper Arkansas, Colorado (275).

Amarantus retroflexus, L.-Twin Lakes, Colorado (274).

Amarantus albus, L.-Arizona and Utah.

\section{CHENOPODIE A.}

Sarcobatus vermiculatus, Torr.—“Chico," Utah; San Luis Valley, Colorado, common $(265,263)$. New Mexico (87, and by Loew 265). Male flowers, Utah.

SudedA DIFFusa, Watson (Suceda maritima, Watson, in King's Report 5, 294).-Growing 4 feet ligh, abundantly, on the banks of the Gila River in Arizona (773); also from Nevada and Utah. 
StanA derressa, Watson.-Salt-works in South Park, Colorado (267); and also the var. ERECTA, Watson, $1-2^{\circ}$ high, branches short and leaves narrow (276), South Park.

Teloxys* CORnuta, Torr-Erect, low herb, simple or branched; leaves (with petiole) $6-18^{\prime \prime}$ long, lanceolate, sinuate-pinnatifid, the usually perfect flowers $\frac{1}{2}-1^{\prime \prime}$ in diameter; calyx resinous-dotted and the lobes keelcrested-Mount Graham, Arizona, at 9,000 feet elevation (737). Nevada.

Kochia Americana, Watson (Proc. Amer. Acad. ix, p. 93).-

Chenopodium Fremontin, Watson.-Twin Lakes, Colorado (253); Mount Graham, Arizona, at 9,000 feet elevation (747); Utah.

Chenopodium album, L-Colorado, Arizona, New Mexico, and Utah.

Chenopodum olidum, Watson (Chenopodium album, in King's Report v, p. 287 in part).-Differs from $C$. album in the smaller leaves, the more loosely panicled, close clusters of flowers, and in the large seed being closely adherent to the calyx.-Twin Lakes, Colorado (258).

Chenopodium ambrosioides, L., var. axthelminticum, Gray.-Old Camp Goodwin, Arizona, at 3,000 feet elevation (343).

Cienopodium leptophyludi, Nutt. (Chenopodium album, var. leptophyllum, in King's Report, v, 287).-Valley of the Arkansas, Colorado (264).

Blitum† RUbrum, Reich., var. humile, Moquin (Blitum polymorphum, var. humile, in King's Report, vol. v, p. 288).-Hot Springs of San Luis Valley, Colorado (water about $80^{\circ}$ Fahr.) (272).

Blitum capitatum, L.-Colorado (269, 271).

Blitum gladcum, Koch (Chenopodium glaucum, L, Gray's Man.).Colorado (260, 261, 254).

Monolepis chenopodioides, Moq.-Twin Lakes, Colorado (256).

"Teloxys, Moquin.-" Flowers perfect or sometimes pistillate. Calyx 5- (rarely 4-) parted, the lobes more or less prominently carinate and subcrested. Stamen 1 ( 5 , Moquin) or wanting. Ovary ovate: styles 2, free or united at base. Fruit partially covered by the loosely appressed calyx; pericarp membranons. Seed lenticular, with a crustaceovs testa.-Herbaceous annuals, ereet and diffuse; the minute solitary flowers very shortly pedicelled, axillary and terminal upon the repeatedly dichotonons nearly naked branches; terminal flowers abortive and deciduous, leaving the ultimate branchlets epinulose ; leaves thin, alternate."-W ATron, Revision of North American Chenopodiaceæ, Proc. Aner. Acad. vol. ix, p. 90. dages.

t Butum differs from Cuenorodium in having the seed vertical and the calyx destitute of appen- 
Atriplex* Patula, L., var. hastata, Gray, Colorado (262, and 259 in part); var. LitTuralis, Gray, Colorado (259 in part).

Atriplex expansa, Watson (Proc. Amer. Acad. ix, p. 116).-Annual, erect, much branched; leaves almost sessile, thin, ovate-triangular, or subhastate at base, lower ones opposite; fruiting bracts nearly sessile, broadly cuneate or roundish, distinctly reticulate or muriculate and pale below, herbaceous and irregularly toothed along the free, herbaceous margins, united to above the middle; the interrupted staminate spikes slender and naked above.-A common straggling species growing abundantly on the alkaline flats of the San Luis Valley, Colorado (278).

Atriplex Wolfir, Watson, l.c. p. 112.-Annual, low, scurfy-pubescent, branching, reddish; leaves linear, entire, thickish, margins slightly revolute; "androgynous axillary clusters of flowers very small"; fruiting bracts $\frac{3}{4}$ "long and as broad, united to the top; upper lateral teeth thick, slightly truncate, middle one smaller and somewhat acute; styles short.-San Luis Valley, Colorado (277).-P Pate XXIV. Natural size. Fig. 1. Staminate flower, about 12-15 diameters. 2. Pistillate flower, about 10 diameters. 3. Pistil, about 10 diameters. 4. Section through figure 2. Figs. 5, mature fruit; 6 , vertical section of same; 7, annular embryo; all enlarged about 10 diameters.

Atriplex confertifol.ia, Watson (Obione confertifolia, in King's Report, v, 289).-Nevada and Utah.

Atriplex hymenelytra, Watson (Obione hymenelytra, Tortr. in King's Report, v, p. 290).-Nevada.

Atriplex canescens, James (Obione canescens, Moq.).-This is the 982 in vol. v, King's Report, p. 289, but not 981 of same place. It differs from the latter, which is $A$. Nuttallii, Watson, in having the indurated, fruiting bracts united to the apex, contracted above to a narrow orifice and pedicelled, and not muriculate; the fruiting bracts of $A$. Nuttallii, Watson, being united to above the middle, the orifice hardly contracted, and the sides usually muriculate-toothed, and fruit mostly sessile. See Watson, Revis. Chenopod.l.c. p. 120.-Colorado (268). Specimens from New Mexico,

"AtripleX.—" Bracts compressed, more or less united : testa double"-Watson, Revision of N. Am. Chenopod. l. c. 
too young, and in doubt placed here $(126,112)$, were much fiequented by a large black insect an inch or more long. Attached to these were some flies engaged in sucking the juices of the larger insect.* We found many of the flies still active and adhering to their defunct victims.-Southern Arizona $(555,556)$; Nevada.

Eurotia lanata, Moq.-Common throughout the West, where it goes among the herdsmen under the name of White Sage and Winter-fat,-a really valuable forage eagerly eaten by stock.

Corispermum hyssopifolium, L.-Colorado (37, 866, 872).

Spirostachys occidentalis, Watson (Halostachys occidentalis, Watson in King's Report, v, 293).-Nevada, Arizona, and Utah.

\section{PARONYCHIEA.}

Paronychia pulvinata, Gray.-South Park, Colorado, at 12-13,000 feet elevation (46).

\section{ELAAGNEA.}

Shepherdia Canadensis, Nutt.-Colorado $(58,59)$.

Eleagnus argentea, Pursh.-Colorado (60).

UR'TICEAE.

Celtis reticulata, Torr. (Ann. N. Y. Lyc. 2, 247, and Nutt. Sylva, 1, 133, t. 39).-Leaves somewhat acute, obliquely cordate-ovate, and the nearly entire margins somewhat revolute; veins strongly reticulated on the lower surface and deeply impressed on the upper, papillose-scabrous above, less rough below; fruiting pedicels longer than the petioles; the pisiform berry glaucous, with a somewhat reticulate-rugose nucleus.-Nevada. Not having seen a specimen, I have drawn this description largely from Planchon, in DC. Prod. 17, p. 178.

Number 367, from Camp Grant, Arizona, Mr. Watson regard.s as a new species, for which he has indicated the name of $C$. curtipes. I do not feel like attempting a description from the material at hand. It is a tree 20 feet high, with a diameter of 18 inches, and has a smoothish, white bark.

Urtica gracilis, Ait., San Luis Valley, Colorado (71), and U. aracilis,

" Since this observation was made in 1874 the relations existing between insects and fowering plants have come to be more generally acknowledged, because more fully understuod. I now snspect that the case given above has a deeper history thau appears on the surface. 
Ait, var. occidentalis, Watson (U. dioica, L., var. occidentalis, Watson, vol. v, King's Report, p. 321), Utah.

Urtica dioica, L.-Western New Mexico, Loew.

Urtica Breweri, Watson (Proc. Amer. Acad. x, p. 348).-Perennial, erect, rather slender, spinulose; leaves quite thin, very coarsely and somewhat irregularly toothed, $3-5^{\prime}$ long, $1-1 \frac{1}{2}^{\prime}$ wide, cuneate, rounded, or subcordate at base; petioles slender, $1 \frac{1}{2}-3^{\prime}$ long; flowering panicles loose, about as long as the petioles; ovate achenium $\frac{y^{\prime}}{2}$ long, included in the obovate, hispid perianth. Very variable.-Southern Colorado (71).-PLAte XXV. Natural size. Fig. 1. Staminate flower. Fig. 2. Pistillate flower. Fig: 3. Achenium, enclosed by the large inner sepals. Fig. 4. Calyx opened, showing mature achenium. All enlarged about 10 diameters.

Humulus Lupulus, L.-Utah and Colorado (53).

\section{BETULACE $\nexists$.}

Betula occidentalis, Hook.-Northern Nevada, Utah, and Colorado (841).

Betula glandulosa, Michx.-Colorado $(838,839)$.

Alsus incana, Willd, var. glauca, Ait.-Arizona, Utah, and Colorado (840).

Alnus oblongifolia, Torr. (in Bot. Mex. Bound. p. 204).—"Branches smooth and shining; leaves oblong-lanceolate, acute at each end, somewhat doubly serrate, smooth above and minutely pubescent beneath, with surfaces green; nutlets wingless. Tree $30^{\circ}$ high. Leaves $2 \frac{1}{2}-3 \frac{1^{\prime}}{2}$ long and $1-1 \frac{1}{2}^{\prime}$ wide, unequally serrate, serratures glandular at the tip. Petiole about one-third as long as the lamina. Catkins somewhat paniculate, ovate. Nutlets orbicular-obovate, without any trace of a wing." I have not seen the plant, and hence have quoted the above from Bot. Mex. Bound. l. c.Arizona.

\section{PLATANE $Æ$.}

Platanus racemosa, Nutt-Leaves broadly cordate, deeply 5-cleft, divisions sharp pointed, lanceolate, the lower smaller, sometimes only 3-cleft from suppression of the lowest lobes. Upper surface at first covered - with branching, yellow hairs; under surface always whitish woolly; fertile 
heads in long, drooping racemes, 3-5. Styles long; "stigmas at first of a deep and bright brown."-Arizona.

\section{SALICACEAE.}

Salix amygdaloides, Anders. (Sal. Bor.-Amer.) (S. nigra, Marsh, var. amygdaloides, Anders. DC. Prod. 16, 2, 201.)-Leaves broadly lanceolate, 3-6' long, $\frac{1}{2}-1 \frac{1}{2}$ ' wide, with a long tapering point, glaucous beneath, closely serrate, petioles long and slender, stipules minute and very early deciduous: aments leafy-perluncled, elongated-cylindrical, pendulous; the fertile when in fruit lax, 3-4' long, $\frac{1^{\prime}}{2}$ thick; scales in the male ament ovate, villous with crisp hairs, in the female narrower, somewhat smooth, fugacious: capsules globose-conical, glabrous, long-pedicelled; style very short or obsolete, stigmas notched. Denver, Colorado (823). From Utah to Missouri; frequent along the Platte; northward to Red River and eastward to the shores of Lake Erie. In aspect very unlike S. nigra, and in fact more frequently mistaken for S. lucida. The broad leaves, being supported by long and slender petioles, are mored by the slightest breeze, displaying in rapid, fluttering suceession their conspicuous white under surfaces, thus producing an effect in striking contrast with the changeless, soft light reflected from masses of the foliage of $S$. nigra when swayed gently by the wind.

Salix longrolia, Muhl.-Santa Fé, N. Mex., Denver, Colo., June (822).

Salix rostrata, Richards. (S. livida, Wahl., var. occidentalis, Gray. S. vagans, var. rostrata, Anders.) - South Park (821); Georgetown (number 826 in part); Arizona.

Salix Nove Anglie, Anders., var. pseudo-cordata, Anders. (Sal. Monogr. 161, and DC. Prod. 16, 2, 253).-Leaves oblong-lanceolate, acute or acuminate, the earliest obovate-oblong and somewhat obtuse, closely and slightly serrulate or crenate, bright green and glabrous on both sides, reticulate-veined, the young drying black, stipules on vigorous shoots large, semicordate, on twigs and flowering branches small or none; aments short, oblong-cylindrical, about $1^{\prime}$ long, densely flowered, at first wrapped in the

* For the elaboration of this geuus I an indebted to Mr. M. S. Bebb, who, more than auy other American, is placing onr knowledge of this most difficult gronp on a satisfactory basis. 
leaves of the short peduncle; scales obovate, black, villous with white hairs; capsules conic-rostrate, glabrous; pedicels about twice the length of the nectary; style medium-sized, pale, stigmas entire, erect. South Park, Colorado (825); also Georgetown (826 in part). Differs from S. cordata in the more compact aments, subsessile capsules, and leaves green on both sides and slightly crenate-not glandular-serrate. Apparently a common willow in the Rocky Mountains of Colorado, having been collected there by Hall, Greene, Porter, Patterson, Brandegee, and others. Under the inappropriate name of S. Nova Anglice (for British American), Professor Andersson has arranged a series of forms, intermediate, as it were, between our $S$. cordata and S. Myrsinites of Northern and Arctic Europe and Asia, probably including several good species, which, with better material, may hereafter be separated.

Salix desertorum, Richardson (DC. Prod. 16, 2, 281; Porter, Fl. Col. 128).-Leaves narrowly oblong, rigid, more or less whitish-tomentose beneath; aments very short, subglobose, densely flowered; scales pale rose-color, densely white villous; capsules ovate-conical, white-woolly, sessile; style 2-parted, brown. A low, scraggy, much branched shrub, rising to the height of two or three feet, or even more, when it descends into the valleys.-South Park, Colorado, June $(819,829)$. To this species should be referred Hall \& Harbour's No. 523 (very similar to Drummond's No. 657) and most of the so-called S. glauca of the Colorado Mountains.

Salix Wolfir, Bebb, sp. nov.-Leaves oblanceolate, or the lower narrowly oblong, acute, entire, silky when young, with a tendency to blacken in drying, at length smooth, rigid, and green on both sides; stipules none; aments small, subglobose (less than $\frac{1^{\prime}}{2}$ long), densely flowered, scarcely peduncled, with $3-4$ bracts at base, which exceed in length the mature, fertile ament; scales obtuse, black, very sparingly villous ; capsules conical, from an ovate base, pointed, glabrous, subsessile, greenish or dull red; pedicels barely equalling the gland; style slender, greenish or dull; stigmas small, bifid or entire.-South Park, Colorado (820, 824, 828; also collected by Dr. Parry on Wind River, 263, in Captain Jones's Wyoming Expedition, 1873). Resembles the foregoing in habit and in the form of the leaves and aments, but distinguished by the perfectly 16 вот 
smooth, reddish capsules, the black, scantily villous scales, and the leaves colored alike on both sides; aments somewhat as in S. Novæ Anglie, var. pseudo-myrsinites, Anders., but that has beaked capsules and glabrous, crenate leaves, which are membranous in texture and prominently reticulate-veined.

Salix Reticulata, L. (Watson, vol. v, King's Report, p. 327; Porter, Fl. Col. 128).-Half Moon Creek, Colorado, at 13,000 feet elevation (830).

Populus monilifera, Ait.-Nevada.

Populus balsamifera, L., var. angustifolia, Watson-Nevada and Utah, and San Luis Valley and Denver, Colo. (833, 834). Var. candican's, Gray, Colorado (835).

Populus tremuloides, Michx.-San Francisco Mountains, Arizona; also South Park, Colorado (832).

Populus angulata, Ait.-Denver (831).

\section{EUPHORBIACEA.}

By Dr. George Engelmann.

Croton corymbulosus.-Many erect stems from a ligneous base, a span to a foot high, simple below, branching upward; stipules subulate, deciduous; petioles about half as long as the oval or oblong, mostly acutish, leaves, which are $\frac{3}{4}-1 \frac{1}{4}^{\prime} l o n g$, the lowest ones broader and shorter and often acutish at base, all triplinerved at base, penninerved upward, whitish below, greenish-gray above; stellate hairs slightly united to scales above, almost free and loose below; inflorescence short, loose-flowered, corymb-like, 6-8" wide, mostly monœeious; pedicels $2-3^{\prime \prime}$ long, much longer than the flowers; male flowers with 5 spatulate or lanceolate bearded petals alternating with the 5 lobes of the disk; 6-13 stamens with bearded filaments; female flowers mostly apetalous; styles bifid to below the middle or usually to the base, and together with the ovary and the oblong ( $3^{\prime \prime}$ long) capsule stellate scaly; seeds linear-oblong, $2^{\prime \prime}$ long, delicately punctate-reticulate- Camp Bowie, New Mexico, Rothrock, $1 \times 74$ (506). Through Western Texas (Wright, 641, 1805) into Mexico (Saltillo and Buena Vista, Gregg, 71, 288). This species was first described by Torrey in Bot. Mex. Boundary, p. 194, under the name of $C$. Lindheimerianus, in which Mïller, DC. Prod. 15, 2, 579, followed him. But Scheele's plant thus named and described in 
Linnæa, 25, 580, is an annual, mistaken by him for a shrub, which was collected by Lindheimer near New Braunfels, Tex., in 1846, and distributed in his sets under No. 526, and lately rediscovered along a railroad in the Indian Territory by G. D. Butler. This plant was by Müller taken for Nuttall's C.ellipticus, from Saint Louis, which is, however, identical with $C$. monanthogynus, Michx., and in Gray's Manual, ed. 5, 438, the same species was again described as $C$. eutrigynus.

Croton Texensis, Müll. l. c. 692.-An annual, erect, diceious plant of the southwestern plains, Texas and New Mexico, 1-3 ${ }^{\circ}$ high, canescent or greenish-gray (when it is $C$. virens, Müll. l. c. 690), with linear-oblong leaves $2 \frac{1^{\prime}}{2}$ long on petioles $\frac{1}{4}-\frac{1^{\prime}}{2}$ long, without any glands; stellate hair free, not scaly; flowers apetalous; stamens usually 10-13; filaments hairy; styles twice or thrice 2-cleft at base, and, like the capsules, stellate-canescent; seeds orbicular-ovate, somewhat compressed, with a small deciduous caruncula below the apex.-Santa Fé, N. Mex., Rothrock, 1874 (37), originally described by Nuttall as C. muricatus, a name already preoccupied. Hendecandra Texensis, Klotzsch, and $H$. multiflora, Torr., are other synonyms for this plant. Nuttall's name refers to the curious knobs or almost spines on the capsule, which are covered with prominent tufts of stellate hairs. The styles are twice or often three times cleft, so that there are 12 to 24 stigmas.

Acalypha Lindheimeri, Müll. l. c. 875.-Many weak, ascending, downy stems from a thick ligneous root, a span to a foot high, branching from the base: leaves lanceolate-ovate, acute at both ends, serrate upward, hairy, on short petioles, lower ones broader and shorter; slender, dense-flowered, terminal spikes $2-3^{\prime}$ long, staminate upward; shorter spikes from the uppermost leaf-axils ; bracts oval, deeply dentate; styles divided into many very slender, long-protruding, red branches--Ash Creek, Arizona, Rothrock, 1874 (299), and through New Mexico to Western Texas.-Very near the Mexican A. phleoides, Cav., with which Torrey, Bot. Mex. Bound. 199, was inclined to unite it. The slender spikes with the delicate bright red fringes give the plant a very elegant appearance.

Jatropha macrorhiza, Benth. Pl. Hartw. 8; Müll. l. c. 1087, var. SEPTEMFIDA.-Stems a span to a foot high, glabrous, very leafy; leaves 
glalorous, with the nerves of the upper surface puberulent, cordate, with an acute sinus, broader than long, divided about $\frac{3}{4}$ or more into 7 ovate or ovate-lanceolate, incisely dentate, aristate lobes; stipules (2-3" long) setaceously divided; petioles about $\frac{1}{2}-3$ the length of the leaf; cymes densely many-flowered, short-peduncled, somewhat puberulent, with subulate-setaceous, entire, or the lower ones setaceously ciliate, bracts; sterile flowers $\frac{1}{2}$ long, with lanceolate, aristate, usually entire calyx-lobes, half as long as the spatulate petals; 5 (or rarely 6 ) exterior and 3 longer interior stamens, all united to about half their length, bearing equal, linear-oblong anthers; calyx-lobes of fertile flowers broader, lirger, spinulose-dentate; styles 3, each with 2 oblong stigmas; capsule obtusely triangular, oblong, $\frac{1}{2}$ or more long; seeds linear-oblong ( $4-5^{\prime}$ long), with a large hoodlike, cut-fringed caruncle.Sulphur Springs, Arizona, Rothrock, 1874 (546), and to Southern New Mexico and Chihuahua, Wislizenus. Leaves in the smallest specimens (Wislizenus, Chihuahua) $2^{\prime}$ long by $2 \frac{1}{2}^{\prime}$ wide, in Rothrock's largest $6^{\prime}$ by $8^{\prime}$, always with 7 lobes and usually with 2 smaller additional ones at base. Evidently a form of the Mexican J. macrorhiza, and with the same curious caruncle of the seed, distinguished by the longer petioles, the much more deeply divided leaves, with more numerous and more deeply cuttoothed lobes, and an acute (not wide or truncate) sinus Torrey's, J. multifida, Bot. Mex. Bound. p. 198 (not Linn.), is evidently the same thing, as already suggested by the author himself, and probably nearer Bentham's type than our plant, as the leaves are said to be only 3-5-lobed.

Luphorbia (Anisophyllum) albomarginata, Tort. \& Gray in Pacif. R. R. Report, 2, 174; Bot. Mex. Bound. 186; Boissier in DC. Prod. 15, 2, 30.-A prostrate, much branched, glabrous, glaucous perennial, with orbiculate-cordate, entire, rather fleshy leaves (2-3" wide) and conspicuous, triangular, membranaceous, whitish stipules; involucres axillary, solitary, or sometimes crowded into foliaceous cymules, broadly campanulate with conspicuous, white, transverse, entire or undulate appendages of the glands; capsules triangular; seeds reddish-gray, linear or oblong, smooth or sometimes very slightly undulate.-Zuñi, Rothrock (173 in part), 1874, to Fort Tejon, California (274), 1875, and generally from Westem Texas to Southorn Califormia and into adjoining Mexico. A very distinct species, easily 
recognized by its glaucous color and whitish stipules and white appendages. In Arizona it is called "Rattlesnake-weed", as its acrid juice is considered an antidote against the venom of that reptile. In Mexico, to this, as well as to other allied species, known under the name of Golondrina, great medicinal virtues are ascribed.

Euphorbia (Anisophyllum) flagelliformis, Engelm. in Hayden's Bull. Geol. and Geog. Surv. Terr. 2, No. 3, 243. E. petaloidea, var. flagelliformis, Engelm. in Bot. Mex. Bound. 185. E. zygophylloides, var. flagelliformis, Engelm. in Boiss. l. c. 29-A glabrous annual, with prostrate or ascending branches a span to a foot long; linear or oblong-linear entire leaves, acutish at both ends, $4-6^{\prime \prime}$ long, $1^{\prime \prime}$ wide; conspicuous triangular incised stipules and olternate loose-flowered leafy corymbs; involucres broadly campanulate, with 2-4 large, concave, narrow-margined or inappendiculate glands; broad triangular capsule; smooth gray seeds thick and short, triangular, acute.-Camp Goodwin, Gila Valley, Arizona, Rothrock (339), 1874. Apparently a common plant in the sandy valleys of the Rio Grande (Wright, Brandegee) and Gila, but very rarely collected. Dr. Rothrock's specimens have a ligneous, very stout, tapering root $3^{\prime \prime}$ in diameter, with many stems (1-1 $\frac{1}{2}{ }^{\prime \prime}$ thick) from the neck, just as we sometimes see other annual Anisophylla, E. hypericifolia among them, so that they simulate and actually become perennials; real perennials, however, such as the next species, have cylindric or tuberous roots, usually with slender and even filiform bases to the stems, which are buried beneath the surface. The slender leaves and the short, leafy, alternate flowering branchlets, much shorter than the internodes of the elongated stems, characterize this species at once. Like the Californian E. ocellata, it is distinguished by large cupshaped glands, usually less than four in number, and scarcely or not at all margined.

Euphorbia (Anisopyhllum) Fendeeri, Torr. \& Gray, Pacif. R. R. Rep. 2, 175; Bot. Mex. Bound. 186 ; Boiss. l. c. 38; E. rupicola, Scheele, not Boiss.-Glabrous; many subereet or ascending, short, rigid stems of a finger's length from a perennial root; thick leaves, obliquely triangularovate to lanceolate, $1-2 \frac{1}{2}$ long, entire, often reddish; stipules subulate or somewhat lanceolate; involucres in terminal and lateral leafy cymules; 
glands with narrow or with longer, sometimes triangular, entire or dentate or lobed, greenish or reddish appendages, or without any ; seeds quadrangular-oblong, undulate and scrobiculate.-Santa Fé, Rothrock (13), 1874; number 1003 is the same from Arizona. Not rare from Western Texas, through New Mexico and Southern Colorado to Arizona. A diminutive, suberect bush of many stems and branches, very variable in the width of its leaves, but readily recognized by the characters enumerated.

Euphorbia (Anisophyllum) polycarpa, Benth. Bot. Sulph. 50; Bot. Mex. Bound. 186; Boiss. l. c. 44.-A perennial, often flowering in the first year as an annual, prostrate or erectish, glabrous, sometimes pubescent (or even tomentose in a variety), with orbicular-cordate or oblong entire leaves, always with linear, delicately ciliate stipules; involucres axillary, rarely crowded into few-flowered cymes; appendages of the dark red (or, when dry, black) glands large and conspicuous, or smaller; seeds grayreddish, linear-oblong, quadrangular, smooth or slightly undulate. The typical, large-flowered, glabrous form is found principally along the Pacifice coast from Cape St. Lucas to the southern part of the State of California; inland, and especially in the California Desert and up the Gila, where Dr. Rothrock collected it in 1874, a larger, wide-spreading, very much ramified form is found, with smaller, glabrous or pubescent, oblong or oblong-linear leaves $\frac{1}{2}-1 \frac{1}{2}$ l long, with smaller involucres, very small, almost or entirely inappendiculate glands, and very short styles, but seeds of the same size and form as in the type. The stipules of all forms are alike, linear, entire, minutely ciliate. E. micromera, Boiss. l. c. 44, seems identical with this last form, and we will have to consider E. melanadenia, Torr. Pacif. R. R. Rep. 4, 135, as a tomentose variety, as suggested by S. Watson; an intermediate form is $E$. cinerascens, Engelm. Bot. Mex. Bound. 186.

Euphorbia (Anisophyllum) serpyllifolia, Pers. Ench. 2, 14; Boiss. l. c. 43; Gray, Man. 432; E. inaquilatera, Engelm. Bot. Mex. Bound. 187; not Sonder.-Zuñi, Rothrock, 1874 (173). An extremely variable species, but readily recognized by its glabrous, obovate leaves, acute at the unequal base, broader and serrulate at the rounded tip; stipules setaceously divided; involucres in lateral leafy elusters; seeds gray, linear, acutely 4-angled, slightly wrinkled or pitted. The closely allied E. glyptosperma, Engelm., 
may always be distinguished by the broad semicordate base of the leaves, the lower half of which is protracted and almost auriculate, and by the sharply cross ribbed and at the angles, notched seeds. The form collected at Zuñi is suberect, nearly a span high, with leaves more sharply serrate than usual, and more distinctly rugose.

Euphorbia (Anisophyllum) pediculifera, Engelm. Bot. Mex. Bound. 186 ; Boiss. l. c. 48.-Plant, pale dull green, covered with a short, scanty pubescence; many prostrate stems from a perennial root, a span to a foot long; leaves rather large ( $6^{\prime \prime}$ long or more), oblique, oblong, obtuse, entire; small stipules triangular-subulate; involucres in few-flowered, lateral, leafy cymes; glands with broad, dentate appendages; capsules canescent; seeds oblong, angular, strongly marked with 4 deep transverse grooves, deeply notched on the edges.-Cienega, near Tueson, Ariz., Rothrock, 1874 (576). A native of our extreme Southwest, from Arizona to Southern California and into adjoining Mexico; well marked by its larger, dull grayish-green leaves, and especially by the (for the section) large, deeply grooved and notched seeds, which curiousty simulate some insect.

Euphorbia (Anisophyllum) hypericifolia, Linn.; Bot. Mex. Bound. 188; Gray, Man. 432.-Two forms were collected by Dr. Rothrock in 1874. The common form (672) from Camp Crittenden, Southern Arizona, is that of the States, called E. Preslii, Guss., Boiss. l. c. 22, glabrous, with rather small, blackish, much cross-wrinkled seeds The other form (720), from Camp Lowell, Southern Arizona, has seeds larger than the last, in size between those of E. Brasiliensis, Lam., and the large-seeded E. Bahiensis, Boiss., and in form similar to them; all of these have thick, short, almost ovatecubic, black seeds, with few prominent tubercles arranged in about 2 interrupted transverse ridges. Our plant is nearly glabrous; leaves very pale below, with long, sparse ciliæ on the upper edge near the base.-The different species allied to E. hypericifolia require further study, as it is a mooted question whether the pubescence of the plant and even that of the capsules, and the size, the color, and the markings of the seed, constitute here specific differences. If they do not, then we have here one of the most polymorphous species, spread over all the warmer countries of the 
glohe, anc most difficult to define by floral and carpological, but easily recognized by the vegetative characters.

Euphorbia (Poinsettia) cuphospekma, Boiss. l. c. $73 ;$ E. dentata, var. cuphosperma, Engelm. Bot. Mex. Bound. 190.-A slender, erect annual, 1-1 $1{ }_{2}^{\circ}$ high, simple or with few erect branches, nearly glabrous, with few bristly hairs ; leaves lance-linear, 1-2' long, upper involucral ones longer and a little wider, but scarcely discolored at base, all entire or with a few teeth on the revolute, scabrous margins; the large involucres in loose clusters, deeply campanulate, with 1 or 2, rarely more, slender, almost tubular glands; seeds short and thick, triangular, truncate at base, cross-ridged and tuberculate, with a minute caruncle.-Cienega (Creek), Arizona, near Tucson, Rothrock, 1874 (577).

A rare plant, found only once before, by Wright, mistaken by me for a form of $E$. dentata, but well distinguished from that species (which extends far into Mexico) by its involucres and seeds. E. dentata has much smaller turbinate involucres, with broad glands, and smaller ovate or subglobose, minutely tuberculated seeds.

Euphorbia (Tithymalus) dictyosperma, Fisch. \& Mey.; Boiss. l.c. 135; Gray, Man. 434.-Camp Grant, Arizona, Rothrock (370), 1874.

Euphorbia (Tirnymalus) campestris, Cham. \& Schlecht, Linn. 1830, 84; Boiss. l.c. 146 ; E. esulaformis, Schauer, Linn. 1847, 729; Bot. Mex. Bound. 192.-Several erect stems, $1-1 \frac{1}{2}^{\circ}$ high, from a stout perennial root; glabrous leaves linear-lanceolate; lower branches sterile with narrower leaves, upper ones flower-bearing; terminal umbel 5-rayed; exterior floral leaves ovate-lanceolate, interior ones shorter, but all longer than wide; involucres turbinate-campanulate, on pedicels of nearly their own length; glands semilunate, with short horns; styles longer than the ovary, united at base, bifid upward; seeds ovate, gray, marked with irregular, shallow, dark impressions.

Willow Spring, Arizona, Rothrock, 1874 (213); and southward and southwestward throughout Mexico.-The narrow leaves, especially on the sterile branches, and the narrow floral leaves, distinguish this species from its allies in the Southwest, and approach it, in habit at least, to the European E. Esula. 


\section{SAURURE无.}

Anemopsis Californica, Hook.-New Mexico, Arizona, and Nevada $(554,88)$. This is the Yerba de Mansa of the Mexican population.

\section{JUGLANDE 王.}

Juglans Californica, Watson(Proc. Amer. Acad. x, p. 349).-Floccosetomentose or glabrous; leaflets 5-8 pairs, oblong-lanceolate, usually tapering upward to a point, somewhat falcate, obscurely crenate-serrate, 2-3' long; "male aments $4-8$ ' long, often in pairs; sepals acute or obtuse, veined, $1 \frac{1}{2}$ " long; stamens 30-40, the anthers a line long, with the apex of the connective very short and bifid; fruit globose, slightly compressed, $\frac{3}{4}-1^{\prime}$ in diameter: nut shallowly sulcate, the walls rather thin and with two broad cavities upon each side (J. rupestris, var. major, Torr. in Sitgreaves's Report, p. 171, t. 16)." From the imperfect character of my own material, I have had to quote the above largely from Mr. Watson's description. Tree 20 feet high, and bark somewhat resembling that of the White Walnut.-Southern Arizona, at 5,500 feet (No. 276).

\section{CUPULIFER E.}

\section{Bx Dr. George Engelmann.}

Quercus undulata, Torr. Ann. Lyc. N. Y. 2, p. 248, t. 4; Engelm. in Trans. St. Louis Acad. 3, 382, 392.-A scrubby White Oak of the Rocky Mountains and through Arizona, with annual maturation, very variable in foliage, and to some extent also in stature and habit; leaves from $3-4^{\prime}$ to $1^{\prime}$ or less in length, bluntly lobed or even pinnatifid to spinous-dentate or entire, deciduous to persistent, always downy below, at last glabrate above; anthers 6-8, small, glabrous; stigmas sessile or on short styles; acorns subsessile, or on shorter or longer peduncles; cups deep, scales generally tumid, nut oblong, sometimes elongated, sweet.

Var. GAMbeliI, Engelm. l. c.; Q. Gambelii, Nutt.-A bush or small tree, with larger, bluntly lobed (lobes often retuse or notched), dark green, deciduous leaves, and commonly larger elliptic nuts, in deep, strongly tuberculated cups.-Collected by the different Expeditions over the whole 
territory. A tree 20-30 feet high, at Willow Spring, Arizona, at an altitude of 7,500 feet, Rothrock (252), 1874.

Var. ptacias, kingelm. l.c; Q. pungens, Liebm.-Shrubly, leaves much smaller, often only $\mathrm{I}^{\prime}$ long, of paler color and rigid coriaceous texture, spiny-dentate, often somewhat persistent; acorns smaller, mostly elongated, with tomentose, scaly, usually less knobby cups. Collected throughout Arizona by the different Expeditions.

Var. oblosgata; Q. oblongifolia, Torr. Bot. Mex. Bound. 206, not Bot. Sitgr.-Shrub or small tree with small (1-1 $\frac{1}{2}$ long), oblong, more or less entire, pale, coriaceous leaves, smooth and shining above, scarcely reticulate below; acorns long-peduncled.-On the Mesa south of Black River, Arizona, and in Rocky Cañon, Arizona, Rothrock (292), 1874. A form of this, var. grandifolia, Engelm. l.c., with leaves $3-5^{\prime}$ long, and peduncles $2-3^{\prime}$ in length, occurs occasionally from Southern Colorado to Arizona.

Var. GRISEA, Engelm. l.c.; Q. grisea, Liebm.-With similar-shaped, entire or irregularly dentate, very thick leaves, often cordate at base, below strongly reticulate, and, like the branchlets, yellowish pubescent, with larger, subsessile or short-peduncled acorns. A bush or small tree, $20^{\circ}$ high.Camp Apache, Dr. Girard, G. K. Gilbert, and at Camp Bowie, Rothrock (508), 1874. This form evidently connects with the next species.

Quercus reticulata, H. B K.-A shrubby White Oak, with coarse, persistent, short-petioled, obovate leaves, cordate at base, broader and obtuse above, repandly spinous-dentate, strongly reticulate, and below, together with the branchlets, fulvous-tomentose, sparsely stellate-hairy above; fruit-peduncles about balf as long as the leaves or shorter, bearing one to several acorns in deep, strongly tuberculate cups.-On Mount Graham, Arizona, at 9,500 feet altitude, Rothroek, 1874 (759). A shrub, 2-4 feet ligh, with leaves $2^{\prime}$ long and $1 \frac{1^{\prime}}{2}$ wide. It agrees perfectly with the Mexican forms, which, however, seem to make large trees, often with larger leaves; the leaves of the previous year are found to be persistent even as late as September.

Quercus Emoryi, 'Torrey, Bot. Emory's Exped 1848, 151, t. 9, not of Bot. Mex. Bound.; Engelm. l. c. 382 and 394; Quercus hastata, Liebm.-A shrubby or arborescent Black Oak, with rough, black bark, and dark-green 
foliage, downy when young, glossy and almost glabrous when old, and persistent until the new leaves have come out; branchlets downy; leaves coriaceous, $1 \frac{1}{2}-2 \frac{1^{\prime}}{2}$ long, 5-9" wide, on very short, downy petioles, lanceolate with a cordate or (by the two lowest teeth spreading) hastate base, tapering to a sharp point, repandly spinous-dentate or rarely entire; staminate flowers with 4-5 large anthers, pistillate ones with long, recurved styles; sessile fruit maturing in the first year; cup hemispherical, with brown, triangular, obtuse, almost flat scales, and covering about $\frac{1}{3}$ of the oblong, long-pointed nut.-Rocky Cañon, Arizona, Rothrock, 1874 (287). Extends through Arizona and New Mexico to Western Texas. Botanically a most interesting species, as it combines many characters of the White Oaks, viz., the annual maturation and especially the position of the abortive ovules at the base of the nut, with characters of the Black Oaks, viz., the black bark and coarse wood, the small number and large size of the stamens, the long, recurved styles, and the tomentose inner coating of the shell; the leaves show, as they do in many Black Oaks, a stronger reticulation on the upper than on the lower side.

Quercus hypoleuca, Engelm. l. c. p. 384 ; Q. confertifolia, Torr. Bot. Mex. Bound. 207, not H. B. K.-An evergreen Black Oak, with annual maturation of fruit, forming a middle-sized tree, with dark, rough bark; leaves coriaceous, lanceolate or oblong-lanceolate, tapering into a short petiole, $2-3 \frac{1^{\prime}}{2}$ long, $\frac{1}{2}-1^{\prime}$ wide, revolute on the margin, entire or with a few broad teeth toward the tip, glabrous and shining above, white-tomentose, with smoother and darker ribs below; 4 glabrous anthers in the 5-lobed calyx; styles recurved; acorns sessile or short-peduncled; cup-scales ovatetriangular, obtuse, bright brown.-Sanoita Valley, Southern Arizona, at 7,000 feet altitude, Rothrock, 1874 (653); also found on the San Francisco Mountains. A very conspicuous and as yet little known species, which Dr. Rothrock found 30 feet high and 1 foot in diameter.

\section{LORANTHACEA.}

By Dr. George Engelinann.

Phoradendron flavescens, Nutt.-The collection contains a number of specimens, which represent two distinct forms, different from the com- 
mon Eastern type. The first may be characterized as var. macrophyllum, with large orbicular-obovate, glabrate leaves, only in the young state with an evanescent pubescence, $1 \frac{1}{2}-2 \frac{1}{2}$ long, 3 - and often 5-nerved ; staminate spikes unusually thick, with 4 or 5 short joints, each with 10-40, comparatively large, pubescent flowers.-They grow on soft woods (Ash, Willow, Poplar, Sycamore, and Sapindus) on the Gila and Bonita Rivers, and extend into Southem California, G. K. Gilbert, Dr. Rothrock.

Var. villosum (Phor. villosum, Nutt.), with woolly, obovate, and var. oRBiculatum, with rourided, pubescent leaves, are found on hard woods, principally on Oaks, in Oregon, California, Arizona, and southeastward. On the mountains about Camp Apache, Arizona, they grow on different varieties of Quercus undulata.

Phoradendron Californicus, Nutt. Pl. Gambel. p. 185.-Slender, terete, much branched, leafless stems, $1-2^{\circ}$ long, bearing, in the axils of the opposite, connate, acute, spreading scales, numerous short, pubescent, 1- or few-jointed spikes, each joint with 2-6 flowers; staminate flowers with oblong anthers, the cells opening longitudinally-Arizona and Southern California, G. K. Gilbert, Dr. Rothrock, on Mimosea, Larrea, and a few other shrubs.

Phoradendron juniperinum, Engelm. Pl. Fendl. p. 58.-Half a foot to a span high, densely branched; small, obtusish leaf-scales ciliate; staminate spikes very short, mostly with a single 6-8-flowered joint, pistillate ones with only two opposite flowers.-Common on different species of Juniper throughout Arizona and in the adjacent districts; collected by all the different Expeditions. The short joints are so fragile that the dried specimens easily break up.

Arceuthobium* Americanum, Nutt.; Engelm. Pl. Lindh. 214.-Slender, dichotomously and verticillately much branched, greenishl-yellow; staminate

- Arceutrobium, Bieb.-Flowera diacions, axillary and terninal, single or soreral from the same axil; staminate flowers mostly 3- (rarely 2-, 4-, or 5-) parted; the axillary buds compressed, the teruinal oves globose; circular anthers aduate to the lobes, 1-celled, after opeving saucer-shaped; pollen-graius spinuiose; pistillate flowers compressed, ovate, subsessile; pedicel at length elougated, and at maturity recurved; berry compressed, flesby, dehiscent at the circumselssilo base. Glabrous, jointed, shrubby parasites of Conifers, of greenish or brownish color, with quadrangular branches and scale-like leaves conuate into sheathing cups ; flowers often crowded into apparent epikes or panicles, opening in spring, summer, or autumo; berries mature in the second autumu, when they suddenly and forcibly eject the glutinous seeds to the distance of soveral yards. 
plants, $2-4^{\prime}$ high, $1-1^{\prime \prime}$ thick at base; fertile plants much smaller; flowers small, staminate ones $1^{\prime \prime}$ wide, lobes ovate-orbicular, acutish; pistillate flowers $\frac{1}{2}-1^{\prime \prime}$, fruit $2^{\prime \prime}$ long.-Only on Pinus contorta, Rocky Mountains to Oregon and California; near Breckenridge, at 10,000 feet altitude, Wolf, 1873. Flowers late in autumn.-In this and the next species, accessory flowers or flowering branchlets are developed on the fruiting specimens, in this lateral, in the next dorsal to the fruits or fruiting branches. In these two we find no other secondary formation on the fertile plants, but in the other species sterile branchlets are developed on them which would flower in the following year; thus these latter continue their existence for a longer time than the two first ones.

Arceutнoвium Douglasir, Engelm. ined.-Slender, small, 1-1' high, greenish-yellow, dichotomously branched; branches suberect, single or with accessory ones behind the first; flowers in short, usually 5-flowered, spikes, staminate ones less than $1^{\prime \prime}$ wide, with orbicular-ovate acutish lobes; fruit $2 \frac{1}{2}$ " long.-On Pseudotsuga Douglasii from New Mexico (on Santa Fé River, Rothrock, No. 69, 1874) to Utah, Parry, Siler, and Northern Arizona, Camp Apache, G. K. Gilbert (109), 1873.-Flowers May-June.Similar to the last, but smaller, and never with verticillate branchlets or flowers, which are so common in that species The thallus-like tissue or stroma, which creeps along within the bark of the nurse plant, buds out in autumn all along the three years old shoot; after about 12 months, the flower-buds are formed, to open in the following spring, after which the life of the male plant is exhausted; but it takes another year to perfect the fruit. The female parasite, now fully three years old, generally dies, but sometimes lives and fructifies another season. The Northeastern A. pusillum, Peck, behaves in the same manner, while in $A$. Americanum and some other species the buds of the parasite make their appearance at first only among the older bud-scales of the pine branch.

Var. ? microcarpum is parasitic on Picea Engelmanni, found by. Mr. Gilbert in 1873 (100 and 102) in the Sierra Blanca, Arizona; it is a little taller, 1-2' high, but has much smaller fruit, only $1 \frac{3^{\prime \prime}}{4}$ long, the smallest of any American species.

Arceuthobium divaricatum, Engelm. ined. A. campylopodum, var. 
Engelm. Pl. Lindh. 114-Much stouter than the last, 2-4' high, below $1^{\prime \prime}$ in diameter, olive-green or light brownish; branches spreading, often recurved; staminate flowers few and scattered, or in 3-7-flowered spikes, $1^{\prime \prime}$ in diameter, with ovate, acute lobes; inflorescence often bearing sterile branches from the same axils as the fruiting ones and behind them; fruit $1 \frac{1}{2}-1 \frac{3 \prime \prime}{4}$ long.

On Nut-pines ( $P$. edulis and monophyllos) from Southern Colorado through New Mexico to Arizona, G. K. Gilbert, 1873 (116), Dr. J. B. Girard, 1874. Flowers August and September. Intermediate in size and color between the last and the following; well marked by its divaricate habit and its scanty flowers.

Arceuthoilim robustum, Engelm. Pl. Fendl. p. 59 ; A. cryptopodum, Engelm. Pl. Lindh. p. 214.-Stout, $2-4^{\prime}$ high, 2-3" thick at base, paniculate, much branched, brownish-yellow to dark olive-brown; staminate plants smaller than the pistillate ones; staminate spikes with much-compressed, adpressed buds; flowers mostly 3 -parted, $1 \frac{1}{4}-1 \frac{1}{2}{ }^{\prime \prime}$ wide; anthers attached above the middle of the ovate, acute lobes; ripe fruit $2 \frac{1}{3}$ " long.

Only on Pinus ponderosa, Colorado, New Mexico, and Arizona; Camp Apache (G. K. Gilbert, 1873) and Mount Graham (Rothrock, 787); 1874. Flowers in June. Fruit mature in August and September. The closely allied A. occidentale, Engelm., is distinguished by more elongated spikes, ventricose, divaricate buds of the staminate, mostly 4-parted, larger flowers, with lanceolate, acuminate lobes and anthers attached below their centre; it also occurs on Pinus ponderosa, but more frequently on other Conifers. Both persist for several years, the female plants always longer than the male.

\section{SANTALACER.}

Comandra pallida, var. angustifolia, Alph. DC-Rocky Cañon, Arizona (273).

Comandra umbellata, Nutt.-Nevada. 


\section{CONIFER E.}

\section{Br Dr. George Engelmann.}

Abies* subalpina, Engelm. Am. Nat. 1876, p. 554; Trans. Ac. St. Louis, 3, 597; Abies grandis in part, of the Rocky Mountain botanists.A large tree, $60-80^{\circ}$ high, with very pale and thin, smooth, or, only in very old trees, cracked, and ashy-gray bark; leaves $\frac{3}{4}-1^{\prime}$ long, dark green above, paler or whitish underneath, on the lower branches flat, grooved above, notched at tip and distichous, those of fertile or of erect shoots all around the axis, sharp-pointed and convex and often with stomata above; cones cylindrical-oblong, retuse, $2 \frac{1}{2}-3^{\prime}$ or $3 \frac{1^{\prime}}{2}$ long, $1-1 \frac{1^{\prime}}{3}$ thick, of purplish-brown color; bracts broadly oval, denticulate, mucronate, much shorter than the nearly orbicular or sometimes somewhat quadrangular seale; purplish wings of seeds nearly twice longer than wide; cotyledons 4-5.

Colorado to Utah on the higher mountains and near to the timberline; extending north and northwestwardly. A poor, soft, almost spongy timber, with paler bark than any other American species. The resin ducts of the leaves are imbedded in the parenchyma, about equidistant from the upper and the lower surface.

Abies concolor, Lindley; Engelm. Trans. 1. c. 600.-A large tree, $80-150^{\circ}$ high, with ash-colored, at last thick and much cracked bark, with longer and broader leaves than the last (in young trees often 2-3' long, shorter in old ones), 2-ranked, and when young glaucous, later pale dull green, with stomata on both sides; leaves on the upper branches obtuse, convex above, often falcate; cones cylindrical-oblong, obtuse, $3-4^{\prime}$ or even $5^{\prime}$ long, $1 \frac{1}{2}-1 \frac{3}{4}^{\prime}$ thick, mostly apple-green, sometimes purplish-gray; bracts orbicular-ovate, mostly mucronate, much shorter than the very

*ABIks, Link, not Don ; Abics sect. (Firs), Gray's Mav. ; Pinus sect. Abies, Enul. Parlat. ; Picé, Don.-Coniferous trees with more or less flattened, and on the sterile branchlets, by a twist near their bases, two-ranked, sessile, persistent leaves, which eventually leave on the branches cirenlar, flat scars; flowering from the axils of the leaves of the previons rear; staminate flowers (usually called staminate aments) in the form of an oval or cylindrical ament; anthers without crests, bursting transversely with large $\left(0.11-0.14^{\mathrm{mm}}\right.$ in the larger diameter) 2-lobed pollen-grains; cones erect on the more or lese horizontal branchlets, unaturing in one season; their scales with their enclosed or exsert membranaceous bracts falling from the persistent axis; seeds covered with balsam-receptacles, and partially but permanently enclosed in the pergamentaccous base of the wing, which covers the onter and laps over the inner surface.-Stately trees of rapid growth, but with brittle and rapidly decaying wood. 
broud, transversely dilated scale; wings of seeds pale, very oblique, as long as wide; cotyledons $5-7$, usually 6 .

Common on the mountains of New Mexico and Arizona. Thence extending through Southern Colorado and Utah and throughout the California Sierras. A tree of beautiful foliage, highly prized in cultivation; furnishing better timber than the last, from which (besides the characters already enumerated) it can always readily be distinguished by the two resin-ducts of its leaves lying close to the epidermis of the under surface. In Colorado as well as in California it has often been named A. grandis, a species which properly belongs to the coast regions of Oregon, the Lower Columbia River, Vancouver Island, etc.

Picea* Engelmanni, Engelm.; Abies Engelmanni, Parry; Pinus commutata, Parlat-Large trees, $60-100^{\circ}$ high, with thin, cinnamon-brown, scaly bark; branchlets mostly pubescent; leaves 4-sided, slender and acute or acuminate in younger, and shorter, stouter, short-pointed, and curved in older trees (especially in higher altitudes), with stomata on both sides; cones oval or oblong, about $2^{\prime \prime}$ long, paler or purplish, falling off at maturity; scales thin, erose-denticulate, broad, with a rounded edge or usually somewhat prolonged upward and truncate; seeds half as long as the very oblique wing, usually with 6 cotyledons.

San Francisco Mountains, Bischoff; Sierra Blanca, Gilbert; Mount Graham, Rothrock (784). The most southern localities known of this northern and sub-alphine species, which extends through the Rocky Mountains to British Columbia and to Oregon, forming extensive forests. A beautiful tree, often $2^{\circ}$ and even $3^{\circ}$ in diameter; timber similar to that of $P$. nigra of the Northeast and $P$. excelsa of Europe: above timber-line, it dwarfs down to mere shrubs, often prostrate, but loaded with cones.

- Picsa, Liuk, not Don; Abies, Don; Alies scet. (Sprnces), Gray's Man.; Pinus sect. Picfa, Endl., Parlat.-Conife rous trees with single evergreeu, more or less 4-sided leaves, which at last separate from a prominent, persistent, ligneous base; flowering from the axils of the leaves of the previous year; staninato flowers as in Abieg, but stanens tipped with a large, nearly orbicular, denticnlate crest; cells opening longitudinally ; pollen as in $A b i e s, 0.09-0.13 \mathrm{~mm}$ in longer diameter; cones pendulous from the ends of short or elongated branchlets, maturing iu one senson; seales and small enclosed membranaceous bracts persistent on the axis ; seeds withont 1 alsam-vesicles, inbedded in the excavation of tho membranaceons base of the wing, which leaves tueir under side nealy free and permits them tu drop out.-Trees of slower growth than the firs, with white, soft, but tongh, cloke, and highly esteemed timber. 
Pseudotsuga* Douglasir, Carrière; Alies Douglasii, Lindl-—Often one of the tallest trees known (in favorable localities, in Oregon, even 300-350 feot high), with very thick, much cracked, brown bark, spreading branches, conspicuous, somewhat persistent bud-scales, slender, flat, linear, obtuse or acutish leaves, $\frac{3}{4}-1 \frac{1}{4}$, rarely $1 \frac{1}{2}$ inches long; cones ovateoblong, usually $2-3^{\prime}$ long, brown, well marked by the protruding, longcuspidate bracts; scales orbicular, concave; oval wings about as long as the somewhat triangular, pale seeds; cotyledons 6-8.

Common through Arizona, as it is through all the western mountain regions, down into Mexico.-Leaves stomatose and whitish only on the lower surface, with 2 resin-ducts close to the epidermis of the under side.

Pinust flexilis, James; Parlat. in DC. Prod. 16, 2, 403.-A middlesized tree, with a smoothish, or, in old trees, lightly furrowed, pale or ash-gray bark; leaves in fives, mostly entire and smooth-edged, $1 \frac{1}{4}-2^{\prime}$ long, in a loose, deciduous sheath, about $\frac{1}{2}$ in length; involucre of the oval staminate flowers composed of 8-9 oval, obtuse scales; anthers with a short lacerate or toothed crest; cones sub-terminal, $\ddagger$ spreading, or slightly reflexed, ovate-cylindrical,

* Pseudotsuga, Carr. Conif. ed. 2, 256; Abies, sect. Tsuga (in part), Endl-Coniferous trees, with flattened, entire, somewhat 2-ranked, distinctly petioled leaves, leaving on the branchlets scarcely prominent, transversely oval scars; flowering from the axils of the leaves of the previous year; staminate flowers resembling an oval or subcylindrical ament; anthers with a recurved, spurlike point; cells rpeniug longitndinally; pollen oval-subglobose; sessile cones subpendulous, maturing in one season; seales and their much elongated bracts persistent on their axis; seeds without balsam-vesicles, not separating from the wing,-Very large trees, with very thick balk and reddish or jellowish wood, of secondary value, which is characterized and well distinguished from the wood of all the allied genera, and of most coniferous woods, by the abundance of spiral vessels, otherwise so rare in this family. The difference in the pollen, the seeds, and the leaf structure make a separation of this genus from $A b i e s$ as wull as from Truga necessary.

† To the character of the geuus Pinus may be added: Staminate flowers surrounded by an involncrum, of a somewhat definite number of scales (3-15 or 20), the lowest, lateral, pair of which are strongly keeled; pollen-grains lobed, similar to that of Abies and Picea, but only half as large, $0.04-0.06^{\mathrm{mm}}$ wide. The bracts of the cones, which, in the sllied genera, remain membranaceons, become here much thickened aud corky, and, together with the scale below them, form a sort of cell for the reception of the seeds. The base of the wing only partially covers the upper side of the seed, and usually forms a mere rim around the seed, which easily separates from it; in a few species, the wing is firmly attached to the seed, and in a fow otbers it is reduced to a narrow margin; the seed never shows balsam-vesicles.

$\ddagger$ The fertile aments of Pinus, and consequently the cones, are usually called terminal, but they never are that, but alwags lateral, and either appear between the uppermost leaves and the terminal lnd, when they nay be called sub-terminal ( $P$. resinosa, Strobus, sylvestris), or the axis continues to clongate after the formation of the aments, when these and consequeutly the cones becomo lateral, the axis bearing leaves and sometimes other auents above then ( $P$. Toda, aud especially inops, and in Lurope, $P$. Halepensis). In some species both forms occur, or only a few leaf-bundles interveus between 17 BOT 
$3-4 y^{\prime}$ long, squarrose by the more or less protruding thin-edged scales, the free part of which is rounded or more or less triangular, rarely reflexed; seeds 5 or 6 " long, somewhat angled, with a narrow deciduous wing-rim; cotyledons 6-7.

Var. $\alpha$. serrulata.-Leaves slender, slightly and distantly serrulate, and as in the two following varieties, with few or scarcely any stomata on the back; cones of the ordinary form.

Var. $\beta$. macrocarpa.-Leaves slender, entire; cones cylindric, 6-8' long, $2 \frac{1}{2}^{\prime}$ in diameter, the apophysis of the seales short, rounded.

Var. $\gamma$. REFLeXa.-Leaves as in last; cones ovate-cylindrical, about $4^{\prime}$ long; apophysis elongated, reflexed.

A middle-sized tree, rarely more than 50 feet high, on the higher mountains of Colorado, New Mexico, and Arizona, extending to Southern California. Var. $\alpha$ was found by Dr. Rothrock on Mount Graham (783); var. $\gamma$, by the same, on Santa Rita Mountain (east of Tucson) and in the Sanoita Valley (6.54 and 1001). The cone of 1001 resembles that of the Asiatic $P$. Koraiensis, or of a small $P$. Ayacahuite from Mexico. Var. $\beta$ was collected on the San Francisco Mountains by Mr. Ferdinand Bischoff in 1871. - The species is intermediate between the true Strobi and Cembra; of the former it has the peripheral resin-ducts, usually 2 , on the dorsal side; with the latter it has the large, almost wingless seeds in common; from both it is distinguished by the back of the leaf being marked by a single, or a few series of stomata. It thus becomes the type of a third section of the Strobus-like Pines, which may be arranged as follows:

1. Cembra, with large, almost wingless seeds; dorsal face of leaves without stomata; resin-ducts of the serrulate leaves imbedded in the parenchyma; $P$. Cembra of Europe and $\Lambda$ sia with appressed, and $P$. Koraiensis of Northeastern Asia with squarrose cone-scales. 2. Flexiles, with similar seeds, but entire or nearly entire leaves, with a few series of stomata on back, with peripheral ducts; $P$. flexilis, $P$. albicautis, and the Asiatic $P$. pygmaa. This last is thus entirely distinct from $P$. Cembra, as a variety of which it has long been considered by Parlatore and other botanists, while $P$. Mandschurica, at least

the anents anel the terminal bud. When, iu the fullowing season, the axis elongates, whilo the amunt matures to a cone, this latter naturally bicomes quite lateral, but we contiune to designate it as sustorminal, in relation to its owu, coütaneons, part of tho axis. 
what I have seen under that name, is a true Cembra, not to be thrown together with $P$. pygmaa, as has been done, and distinguished from Cembra itself by the denticulate Strobus-like leaf-tips. 3. Eustrobi, with distinctly winged seeds, leaves sharply serrulate on the edges and generally denticulate all over the tip, mostly without stomata on the back, and with peripheral ducts, like the last. Of this subsection we have $P$. Strobus, monticola, and Lambertiana; Mexico has P. Ayacahuite; Japan, P. parviflora; the East Indies and Turkey, $P$. excelsa with $P$. Peuce.

Pinus monophyllos, Torr. \& Frem. Report Expl. Exped. 1842-1844, p. 319 , t. 4 ; Parlat. l. c. 378 -A small tree, of scraggy growth, with gray bark and stout, mostly single,* terete leaves (rarely in pairs, and then semicylindrical and entire on the margins), $1 \frac{1}{2}-2^{\prime}$ long, $\frac{1}{2}-1^{\prime \prime}$ thick or wide, with a deciduous sheath; involucre of the staminate flowers of about 6 scales; anthers with a short, entire or denticulate knob; cones subterminal, ovate-subglobose, 2 or $2 \frac{1}{2}^{\prime}$ long and nearly as thick, consisting of few large scales with thick pyramidal apophyses, but without prickles; oval seeds about $\frac{1^{\prime}}{2}$ long, with a wing nearly $1^{\prime \prime}$ wide; cotyledons 7-10.

The oft-described Nut-pine of Fremont's first expeditions, 35 years ago, common from Arizona to Utah and California. This and the following species furnish an important article of food to the Indians and other natives. That single leaf, before its nature was properly understood, troubled botanists a good deal, so that Endlicher, supposing that the single leaf consisted of two agglutinated ones, went so far as to change the name into $P$. Fremontii. They are really single leaves, and the only instance of such leaves in the genus (I do not speak of the primary leaves of seedlings or young shoots, but only of the secondary leaves, which grow in bundles on what we must take for reduced branchlets).

* The fresh leaves of pines, when single, are terete, aud when dry, become grooved and ridged; the leaves which grow in pairs are semiterete, flat on the upper or inner, and convex on the lower or outer side, and only when (on the tree as well as still more in the herbarium) they become dry, they assume that channt lled form which we tind so often described as characteristic of a species; those leaves that grow in bundles of 3 or 5 are convex on the dorsal and ridged on the npper side; those with 3 are flattish, about half as thick as wide; those with 5 are triangular and nearly as thick as wide. It is therefore superfluous to minutely describe the form of the leaves, as that is already given when the number within the shesath is stated, nor is it proper to describe the dried and shrivelled condition. The serratures, their closeness, the size of the minute teeth or their absence (only in a fow Western American species the edges of the leaves are without teeth) are of much greater importance, and to some extent the nature of the tip is also of value. 
Pisus edulis, Engelm. in Wisliz. Mem. note 2.-Similar to the last, but with more slender, entire leaves, mostly in pairs, rarely in threes; stamnate flowers surrounded by a 4-leaved involucre; anthers with a knob or short spur; cones and seeds similar to those of the last species, only a little smaller; cones usually but $1 \frac{y^{\prime}}{2}$ long; cotyledons as in previous species.

Camp Bowie, Arizona, Rothrock (493). Common from Southern Colorado through New Mexico to Arizona. The two species here deseriberl, together with the slender and 3-leaved $P$. cembroides, with harder shells to the larger seeds, and 8-12 cotyledons, and the little-known 4-5-leaved P. Parryana of the northern part of Lower California, constitute a small group of very peculiar Pines, which we may designate as the Cembroid Pines, characterized by the leaves of the flexilis group (with entire margins, peripheral ducts, and deciduous sheaths), by the seeds of Cembra and liy the cones and scales of Pinaster. Perhaps it would be proper not to lay too much stress on the number of leaves and minor characters, nor on their geographical difference, and to unite them under the oldest and most appropriate name of $P$. cembroides, Zucc., though systematists, counting the leaves, have separated them widely in their books.

There is no pine entirely analogous to them in the Old World, unless we should refer here the little-known P. Bungeana, Zucc.; Murr. Conif. Jap. 18, of Northern China. It has similar, small, subglobose cones, though with less prominent knobs, but armed with recurved prickles; the seeds are smaller, with a very distinct wing, the leaves in threes lose their sheaths as our Nut-pines do, but are serrulate, and have several peripheral ducts, but, singularly enough, also usually a single interior or parenchymatous one, forming thus a link between several groups.

Pinus Arizonica, n. sp.-A middle-sized tree, $40^{\circ}$ high, $2-3^{\circ}$ in diameter; branches squarrose, with persistent bracts; leaves in fives, $5-7^{\prime}$ long, $\frac{1}{2}$ "wide, closely serrulate, in a sheath over $1^{\prime}$ long (when old less than half as long); oval cone $2 \frac{3}{4}^{\prime}$ long, $1 \frac{1}{2}^{\prime}$ thick; scales with a prominent knob, which in the lower ones is recurved, armed with a recurved prickle.

On the Santa Rita Mountains, in Southern Arizona, Rothrock (652), in 1874. "The best lumber of that region, there called yellow pine." 'This scems to be a meagre account to found a new species upon in a genus 
so difficult as Pinus, but I find it impossible to unite it with any other of the allied species. It has the cone of $P$. ponderosa, especially of that form figured by Torrey as $P$. deflexa, and, like all forms of that species, it has the peculiarity that the fallen cones, found on the ground, are always imperfect, their lowest part remaining attached to the branch for another season; I do not know of any other pine with this singular character. But we could not well class this 5 -leaved pine with the 3 -leaved ponderosa. On the other hand, the form of the cone and its scales will not permit us to refer it to the Mexican $P$. Montezume, though the structure of the leaf is very similar to that of this polymorphous species, which appears to includo even $P$. Hartwegii. The three parenchymatous ducts of the leaf and the strengthening cells* within the sheath of the vessels are exactly as we find them in Montezuma, and different from ponderosa.

Pinus ponderosa, Dougl. Parlat. l.c. 305.-A large tree, with large and spreading head, thick, deeply cracked, red-brown bark, and heavy, resinous, yellowish wood; thick branchlets, rough from leaf-scars and the persistent remnants of bracts; leaves in twos or mostly in threes, $4-8^{\prime}$, in some rare forms $10-12^{\prime}$, long, $3^{\prime \prime}$ wide, with sheaths at first $1^{\prime}$ long, when old withering to 2 or $3^{\prime \prime}$ long; staminate flowers cylindric, with an involucre of 10 or 12 scales, the lowest pair of which is about two-thirds as long as the innermost; anthers with a large sub-orbicular crest; fertile aments subterminal; patulous cones oval or rarely elongated, very variable in size, $2-6$ ' long; knob of the scales more or less prominent, and in some forms even recurved, bearing a rather stout prickle; seeds black, ridged on the lower side, wing broadest in the middle; cotyledons $6-8$, or in the largest seeds as many as 10 .

Colorado, New Mexico, and Arizona, extending through the Northern Rocky Mountains and adjacent regions to Oregon and California, mostly in the middle altitudes; the most common and most useful timber of many

*This name has been given to longitudinal cells with rery thick walls, flestitute of chlorophy!l, which are characteristic of most pine-leaves, and by their different disposition aid in distinguishing them from one another. They are generally arranged close to the epidermis, and especially in the angles of the leaves, and have usually about the same diameter as the epidermis-cells themselves. We find them also occasionally surrounding the ducts, e. g. in P. ponderosa, also in the Cembroid Pines and in $P$. Balfouriana and $P$. aristata; while in $P$. flexilis they always leave the ducts free, a character by which we can readily distinguish the leaves of these species, otherwise so similar. Not rarely are they found within the sheath, strengthening, as it seems, the centre of the leaf. 
parts of that district and generally known there as "yellow pine". A most variable tree, several forms of which have received distinct specific appellations, but the specimens collected in these expeditions all appear to belong to the ordinary smaller-leaved and smaller-fruited form. Whenever the macroscopic characters leave any doubt, the microscopic structure of the leaf appears to offer a sure guide. The leaves contain two or three or often more parenchymatous resin-ducts, usually of uneommonly small dianieter, always with some, and often surrounded by many, of those strengthening cells of which I have spoken before; the same cells occur within the sheath, above and below the bundles of vessels. I have examined the leaves of 20-30 specimens from the whole range of the species, and have never failed to discover this same structure, which I must therefore consider as characteristic of the species.

Pinus Chinuahuana, Engelm. in Wislizen. Mem. note 26 ; Parlat. $l$. $c$. 397.-A middle-sized tree, with ternate, closely serrulate leaves $2 \frac{1}{2}-4^{\prime}$ long; the loose glistening sheaths $\frac{1^{\prime}}{2}$ long, deciduous after the first season; staminate flowers slender, cylindric, about $\frac{y^{\prime}}{2}$ long, sometimes interspersed among the foliage; involucre as long as the nearly entire-margined bract, of 8-10 scales, the outer about half as long as the inner ones; anthers with an almost orbicular crest; oval cones sub-terminal, small, $1 \frac{1}{2}$ long; knobs of the scales bearing recurved, deciduous prickles.

Southern Arizona, in Sanoita Valley, at 6,500 feet altitude, Rothrock (649), in 1874; also Wright, and in Western C'hihuahua, Wislizenus.- $\mathrm{\Lambda}$ tree 30-50 $0^{\circ}$ high, "with bark resembling yellow pine "; easily distinguished by the characters given, and especially by its deciduous sheaths. All the Strobi and Cembroids have such deciduous sheaths, but among the Pinasters the sheaths are persistent, except in one or two Mexican species, in $P$. Bungeana, above mentioned, and in this species. Leaves strongly and closely serrulate, and with three or often four parenchymatous ducts.

Pinus contorta, Dougl., var. Latifolia, Engelm.; P. Murrayana, Balf. Oreg. Com. Rep. $\mathrm{A}$ middle-sized tree, sometimes $60-80^{\circ}$ high, and $2-1^{\circ}$ in diameter, with thin, scaly bark of grayish to red-brown color, and close, white, rather soft wood; leaves in pairs, $1_{2}^{1}-2^{\prime}$ or rarely $3^{\prime}$ long and $1^{\prime \prime}$ wide; staminate flowers oblong, $6^{\prime \prime}$ in length, their involucre commonly of 
6 scales; crest of the anthers rounded; pistillate aments subterminal, their scales with erect or spreading points ; cones oval, usually very oblique, and often curved, reflexed, $1 \frac{1}{2}-2^{\prime}$ long; scales, especially the lower ones, with largely developed pyramidal knobs in the centre, much smaller on the inner side, armed with strong or sometimes slender, awnlike prickles; seeds black, rough, ridged on the lower side; wing widest below the middle; cotyledons usually 5 .

Southern Colorado to California, apparently not noticed in Arizona. $\Lambda$ valuable timber tree of the northern mountain regions, forming large forests in the higher altitudes of the Rocky and California mountains, reaching into the British Possessions. The original form, discovered by Douglas near the mouth of the Columbia River (P. Bolanderi, Parlat.), is a seaside tree, extending up and down the coast, resisting the ocean storms, as does $P$. Halepensis those of the Mediterranean, and protecting the inside vegetation; it is distinguished by its low, scrubby, and often shrubby growth (whence probably the name), and its slender leaves, not more than $\frac{1}{2}-\frac{2}{3}$ " wide; northward, in British Columbia and Alaska, both forms completely run together. The species was formerly confounded with the Eastern $\boldsymbol{P}$. inops, which differs by its lateral, more or less pedunculated cones; it is more closely allied with the Northern $P$. Banksiana, which, however, bears its scarcely prickly or entirely unarmed, mostly lateral, rarely subterminal, cones erect or patulous, never recurved: a very unusual occurrence among pines. The cones of the Rocky Mountain form, and also those of the seaside scrub, are usually persistent for many years, and often remain closed after maturity (serotinous), while in the variety of the Sierras they appear to open on maturity, and to drop before the following season, as Prof. C. S. Sargent observed.

Juniperus Virginiana, Linn,; Engelm. American Junip. in Trans. Ac. St. Louis, 3, 591.-Santa Fé, N. Mex., Rothrock, in 1874 (43). Readily distinguished by its slender branchlets and leaves with entire margins.

Juniperus occidentalis, Hook., var. MonosPerma, Engelm. Junip.590.A small tree or a bush, with fibrous bark, squarrose branches, and obtuse, minutely denticulate leaves in twos and threes; berries globose, blue-black, or sometimes copper-colored, 3-5" thick, resinous, pulpy; seeds 1 or 2. 
Chiricahua $\Lambda$ gency, Arizona, Rothrock. A form common from Southem Colorado to New Mexico and westward; distinguished from the origrinal $J$. occidentalis of Oregon and California by its more squarrose growth, thinner branches, and smaller fruit.

Juniperus pachyphles, Torr. Bot. Whipp. in Pac. R. R. Rep. 4, 142; Engelm. l. c. 589.-A middle-sized tree, with spreading head and thick, fissured bark; branchlets slender; leaves elongated, often resiniferous on the back, with slightly denticulate margins; berries large, glaucous, manyseeded.

An important tree in Western New Mexico (Fort Wingate, Rothrock, number 140, in 1874) and Northern Arizona; readily distinguished from all the other species by its bark, which Dr. Rothrock compares with that of the white oak, and others with the bark of pine.

Juniperus Californica, Carr., var. Utahensis, Engelm. Junip. 588. More slender than the western type, J. Californica, with thinner branches and smaller, not so strongly fringed leaves, often in twos; smaller; more globose berries; embryo with 5 cotyledons, as in the species.

Camp Apache, Arizona, Gilbert, Rothrock.

\section{GNETACE E.}

Ephenra antisypulimitica, C. A. Meyer-Arizona and New Mexico. Emedra trifurca, Torr--Arizona and New Mexico.

\section{ENDOGENS.}

\section{ORCHIDE Æ.}

Microstylis montana. - Bulb $1^{\prime}$ in diameter; stem $6^{\prime}-15^{\prime}$ high, with 2-3 broad sheatls at base; 1-2 oblong-lanceolate, obtuse leaves, tapering below into sheaths; flowers many, sessile in a narrow spike (which is $2-5^{\prime}$ long), yellowish-white, without the ovary $1^{\prime \prime}$ long, each one subtended by an oval bract $1^{\prime \prime}$ long; sepals equal or nearly so, oval, rather obtuse; lip next the axis, somewhat triangular-ovate, conspicuously sagittate at base, but obtuse or occasionally notched at apex; lateral petals filiform (usually coiled up), somewhat longer than the sepals; column very short, tapering to a point, and with a very minute tooth on either side below; stigma a small depres- 
sion or pit; anther nearly sessile, of two paralld cells, open above, and free above from column, pollen masses two, not divided, or with a mere sulcation, attached to the minute gland on the tip of the column; mature capsules 3-4" long, oval.

It is particulary remarkable in having a dense spike of sessile flowers. Mount Graham, Arizona, at an elevation of 9,500 feet (734). It appears to be extremely rare. I am indebted to Mr. Watson for indicating the genus, and also for the information that the plant was probably undescribed.

Habenaria leucostachys, - ? - Stem leafy; leaves oblong-lanceolate, obtuse; spike long, densely flowered; bracts about as long as the flower. My specimen from Willow Spring, Arizona (269), shows a well-marked, hooded, posterior sepal, such as we might expect to find in $H$. dilatata, but is without the dilated base to the lip and the trowel-shaped rostellum of the latter species; lip lanceolate, not longer than the somewhat curved spur. The locality whence this specimen was obtained was a very cold, damp one (even though in Arizona), at an altitude of 7,195 feet.

HABENARIA HYPERBoREA, R. Br.-Colorado (965).

Habenaria dilatata, Gray.-Colorado; in company with the above. Quite too near some forms of the above species, as the characters on which the distinctions are founded vary immensely.

Epipactis gigantea, Dougl.-Nevada.

Goodyera Menziesir, Lindl-_Entirely in accord with the figure (Spiranthes decipiens, Hook.), 204, Hook. Fl. Bor. Amer., except that on either side of the base of the lip, in some of my specimens, there is a distinctly serrated crest. Other flowers from the same spike have a single crest in the median line.

Mount Graham, Arizona, at 9,500 feet elevation (749).

Spiranthes Romanzoviana, Chamisso.-Mount Graham, Arizona, at 9,500 feet elevation (752); Utah; Colorado.

Corallorhiza MACREI, Gray?-I name this specimen so with great doubt. It will more likely prove to be new, I think. It differs from the genuine C.Macrei in its smaller flowers, short, thick column, spur short, thick, and truncate, the lip oval, and with a distinct auricle on either side at base.

Mount Graham, Arizona, at 9,500 feet (750).-This peak appears to 
be especially a rendervous of our more northern forms of Orchids. It is not unlikely that the summits of the White Mountains of Arizona still further north would show even a greater number.

\section{IRIDE E}

Iris Tolmieana, Herb. Bot. Beechey.-South Park, Colorado, common (967). Dr. Loew also collected an imperfect specimen from further south, probably New Mexico.

Sisyrinchivm mucronatum, Michx. (S. Bermudiana, L., of Preliminary Report, 1874).-Regarded by Mr. Watson as distinguished from S. Bermudiana, L, "by its low and usually very slender halvit, the scape always terminated by a single spathe sessile within the terminal longer bract, and the flowers small, with segments setosely mucronate and capsules globose" (Proc. Apaer. Acad. xii, p. 277). My specimen (945) from Colorado has larger flowers, and is probably somewhat out of range; still I regard it as belonging to this form.

Sisyrinchium Bellum Watson (Proc. Amer. Acad. l. c.).-6-18' high; leaves narrow, smooth, shorter than the smooth stems; terminal bracts 1-3' long, not longer than the peduncle; spathes 2, enclosing 4-7 flowers and maturing 2-4 capsules, which are somewhat obovate and transversely wrinkled when mature; seeds obtusely angled and distinctly roughened, about 10 to the cell, light purple; petals 4-6" long, toothed or slightly mucronate; stamineal column nearly $3^{\prime \prime}$ long and pubescent at the base. The stem is narrowly margined.-Zuñi, New Mexico, 6,500 feet elevation (171).

Sisyrinchium Arizonicum, Rothrock, Bot. Gazette, vol. 2, p. 125.-1-2 feet high; stem proper smooth, ancipital; leaves 6-12 inches long, 2-6 lines wide, gradually attenuate into an acute point, $2-4$ distinct white ribs in centre, and one or more less distinct toward either margin, minutely pruinose-glandular, slightly roughened on the margin; spathe of two lanceolate leaves regularly tapering to the top, somewhat shorter than the peduncles, of which each branch bears from $2-5$ (most frequently 2 ); flowers yellow, $1-1 \frac{1}{2}$ in diameter, bright yellow segments of the perianth broadly lanceolate; anthers 6 lines long, linear, twice as long as the dilated fila- 
ments, which are united about one-third their length; style cleft half-way down into linear divisions; seeds (immature) oval or nearly round, margined, on a funiculus longer than their diameter.-Puate XXVI. Natural size. Fig. 1. Stamen, seen from outside. Fig. 2. The same, seen from inside the flower. Fig. 3. Style. Fig. 4. Flower, with perianth removed. Fig. 5. Mature capsule. All except the first enlarged about 5 diameters.

This handsome species (238) I discovered at Willow Spring, Arizona, at an altitude of 7,195 feet; grows in damp places. There are indications of its presence elsewhere in Arizona, and allied species are found in Mexico.

\section{AMARYLLIDE $E$.}

\section{By Dr. George Engelmann.}

Agave Utahensis, Engelm., Bot. King's Report, 497; Engelm. Agav. in Trans. Acad. St. Louis, 3, 308.-Stemless ; leaves suberect, or outer ones spreading, lanceolate, tapering from a broad base, concave, 6-12' long, 1-2' wide, not constricted above the base, very thick, hard, glaucous and rough, terminating in a long ( 1 inch) pale spine, with broad whitish teeth on the margin; flowering stalk $5-7^{\circ}$ high, with a spike-like raceme of yellow flowers each $1^{\prime}$ long, in pairs, or often in clusters of 4 , on distinct pedicels ; lobes 3 times longer than the funnel-shaped tube, which bears the stamens in the middle; filaments and style not much longer than the perigon; capsule oval subcylindric, about $1^{\prime}$ long.

Northern Arizona, Bischoff, to Southern Utah.

Agave Parryi, Engelm. Agave, l.c.311. (A. Amcricana, var. ?latifolia, Torr. Bot. Mex. Bound. 213.)-Stemless; numerous short and broad (9-12' long and $3-3 \frac{1^{\prime}}{2}$ wide) leaves crowded around the base of the stalk pale, glaucous, with small, almost black, spiny, straightish teeth, and with a dark, horny margin toward the cuspidate tip, which terminates in a robust, somewhat triangular, black spine $1^{\prime}$ in length; stout scape $8-12^{\circ}$ high, bearing a large, branched panicle of cream-colored flowers over $2^{\prime}$ in length; perigon deeply 6-parted; lobes twice as long as tube, which bears the long-exsert stamens in its throat; capsule broadly oval, sessile; seeds larger than in either of the other species. 
Western New Mexico and Northern Arizona; Rocky Cañon, Rothrock (274), in 1874. Parry, Bischoff, only fruit. Dr. Rothrock's observations and very complete specimens enabled me to give a connected account of this species, of which fragments only had been known for many years. Rev. Mr. Greene noticed the abundant secretion of a sweetish liquid filling the tube, which has also been observed in other species. The rootstock is used as a substitute for soap by the natives, under the name of Amole, much like that of Yueca, and, when roasted, is considered a great delicacy, named Mezcal.

Agave Palmeri, Engelm. Agave, l. c. 319.-Stemless; leaves lanceolate, $10-20^{\prime}$ long by $2-21_{2}^{\prime}$ wide, attenuate into a slender, terete, narrowly channelled, brown spine; marginal teeth flexuous or recurved, dark brown; scape as in the last; panicle loosely branched; flowers $2^{\prime}$ long; perigon whitish, lobes a little shorter than tube, stamens from its middle, and, together with anthers and style, long exsert, purplish; capsule cylindric, stipitate; seeds small, roughish.

Camp Bowie, Arizona, Rothrock (496), 1874; Palmer, in Southern Arizona. Similar to the last, but reacily distinguished by its longer, narrower leaves and the other characters enumerated. Used for the same purposes as the last.

\section{ALISMACE E.}

Triglochin Palustre, L.-South Park, Colorado (952).

Triglocinn maritimus, L.-Alkaline plains of South Park and San Luis Valley, Colorado (942, 951).

\section{NAIADE 2 .}

Potamogeton aramineus, L., var. heterophyllus, Fries.-South Park, at 10,000 feet elevation (961). No mature fruit.

Potamogeton perfoliatus, L., var. Lanceolatus, Robbins\%-Twin Lakes, Colorado (960).

Potamogeton marinus, L.-Twin Lakes and San Luis Valley, Colorado (955).

Potamogeton pectinatus, L. (959).

NaIAS MAJOR, Roth.-Huntington Valley, Nevada. 
TYPIIACEAE.

Sparganium Eurycarpum, Engelm.-Swamps of the San Luis Valley (956).

Sparganium simplex, Huds-Twin Lakes (957); swamps of the San Luis Valley (958).

\section{LIIIACE E.}

Fritillaria atropurpurea, Nutt.-Nevada.

Fritillaria Pudica, Spreng.-Nevada.

Lilium Philadelphicum, L.-Central Colorado.

Lloyuia serotina, Reich.-South Park, Colorado (943).

Calochortus Nuttalli, T. \& G.-Utah; also a small-flowered form from Fort Wingate, New Mexico (148).

Calochortus Gunnisoni, Watson (vol. v, King's Report, p. 348).Central Colorado (941); also Eastern New Mexico.

Leucocrinum montanum, Nutt-Clear Creek Cañon, Colorado (944).

Aluium cernuum, Roth.-South Park, Colorado (948).

Allium atrorubens, S. Watson (King's Report, vol. v, plate xxxviii).Nevada.

Allium Reticulatum, Fras.-Denver, Colo. (946).

Allium mutabile, Mx.-South Park, Colorado (947); Willow Spring, Arizona, 7,195 feet elevation (237).

Allium scaposim, Benth,-Small-flowered form from White Mountains of Arizona, at 8,200 feet elevation (197). Vol. v, King's Report, plate xxxviii, figs. 10 and 11 .

Allium anceps, Kellogg.-Mineral Hill, Nevada.

Camassia esculenta, Lindl - Independence Valley, Nevada.

Milla Biflora, Cav.-Southem Arizona at 5,550 feet elevation (523).

Echeandia* Terniflora, Ortega.-Smooth, $6^{\prime}-2^{\circ}$ high; linear leaves

* Echeasdia, Ortega.-Divisions of the perianth 6, with three nerves in the midale of each. Stamens 6, inserted on the base of the perianth divisions, subbypogynous ; filaments retrorsely serrulate. Authers oblong, divided below; style sonewhat club-shaped; stigma three-lobed (slightly) avd papillese; capsnle globose, 3-relled; ovules in 2 rows in each cell; seeds orbicular, compressed ; roots fibrousfascicled; le_ves linear, radicai, ensiforn ; infloresceuce racemose, with two to three flowery, on jointed pedi els, from each bract. 
lardly as long as the scape; flowers $8^{\prime \prime}$ in diameter, dark orange-yellow, on pedicels jointed at or below the middle; seeds 4-7 in each cell, black. Stamens shorter than the style. From the descriptions and from the scanty material at my command, I infer that this is an excessively variable plant--Southern Arizona (537).

Smilacina stellata, Desf-CUtah, and South Park, Colorado (\$53).

YuCCA* BaCCATA, Torr.-A stout species, northward stemless, southward with a low or higher trunk; leaves rigid and rough, $1-3^{\circ}$ long, $1-2^{\prime}$ wide, with a stout terminal spine, the margin with few but thick fibres; panicle oval, almost sessile, with large, thick, whitish bracts; flowers mostly large, 2-3' long; fruit pendulous, pulpy, containing numerous thick seeds.Bot. Mex Bound 221; Engelm. Trans. Ac. St. Louis, 3, 44.

Arizona (only fruit collected) to New Mexico and South Colorado, extending into Southern California and Northern Mexico--One of the coarsest-looking species of this beautiful genus, remarkable especially for its pendulous, edible fruit, which are called dates or bananas by the settlers, and are eaten by the Indians and others.

Yucca angustifolia, Pursh-A stemless or almost stemless plant, with very rigid and sharp-pointed, linear, sparingly filamentose leaves $1-2^{\circ}$ long and $3-6^{\prime \prime}$ wide; raceme almost simple, spike-like, sessile; flowers usually greenish-white; dry capsule erect, large (21-3' long ard half as wide), opening with three valves through the dissepiments, each usually splitting again at tip; seeds very thin, flat, 5-6" in diameter-Engelm. l. c. 50.

Santa Fé, New Mexico, Rothrock (66), and from the Missouri plains to 'Texas and Arizona.

A more showy variety is $\beta$. elata, Engelm. l. c., with a trunk several feet high, very rigid, glaucous leaves, often almost without fibres on the edge; an expanded branching panicle, with larger, showy, white flowers.-Camp Grant, Arizona, Rothrock (382), and Dr. Palmer.

Veratrum $\dagger$ album, L.-Mount Graham, Arizona, at 9,500 feet elevation (395); Utah.

"Dr. Eugelmanu bas kindly furuisbed tho portion un Yucca.

$\nmid$ This + pecimen was first named as abovi. Since this, bowever, Mr. Watson has marked a specimen for the Philad. Acad. Nat. Sciences as Veratrum Californicum, Durand. In vol. v, King's Report, p.

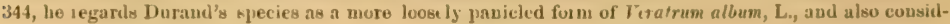


Zygadenus glaucus, Nutt.-Colorado (950). Also from the Mogollon Mesa of Arizona a form corresponding well with the description and with other specimens, save in the shape of the gland, which extends across the lobes of the perianth, but has sometimes no upward heart-shaped divisions whatever (103), Loew. The shape of the gland, I am convinced, is quite too inconstant to serve as a specific test. A specimen from Anticosti Island has exactly the gland of $Z$. Fremontii, Torr., and yet is in all other respects a good Z. glaucus.

Zygadenus elegans, Pursh (Fl. N. Am. vol. 1, p. 241).-1-2 $2^{\circ}$ high, slender, upper leaves few, one or two somewhat elongated but not exceeding the stem; lower leaves narrow (4-6" wide), equal to or exceeding the stem; pedicels in the developed flower 8-12" long, slender, exceeding the narrowly lanceolate, thin, veined bracts; flowers "white" or yellowishwhite, $8-10^{\prime \prime}$ in diameter; divisions of perianth oblong, obtuse, longer than the stamens; racemes often paniculate at base ; oblong ovules in two rows, 20-25 in each cell. In my specimens of this species, the glands are usually deeply and obtusely two-lobed, with the lobes entire and the veins indistinctly seen. In a specimen of $Z$. chloranthus, Rich. (for which species I at first took this), from Fort Yukon, Alaska, the glands are less deeply lobed, with the lobes truncate and distinctly toothed, and the veins quite plainly seen. Not only do these shapes and divisions differ in the same species, but often markedly in the same flower.

By Pursh, the flower is said to be white, the petals acute, and the gland cinnabar-colored, in which points my specimens certainly do not agree with the description. Mr. Watson, on comparing this with the plants in the Cambridge herbarium, names it as above; and I do not hesitate to accept his determination - Mogollon Mesa, Arizona, Loew (103); Willow Spring, Arizona, at 7,195 feet elevation (243).

Zygadenus Nuttallit, Gray.-Apex, Colorado (944).

ers our eastern $V$. riride, Ait., as diffeling frcm $V$. album, L., "ovly in the green herbaceous perianth, the segments perhaps rather less attenuate at $l$ are, the panicle nore open and witb longer branches." The Oiegon form (probably the same with whic h Dnand rontrasted his $V$. Californicum in Plant. Prutten. Calif. p. 103) Mr. Watson decides to be V. Eschsclioltzii, Gray.

Cunparing the spesimen (395) from Mount Grabam with an eastern $\nabla$. viride, Ait., I find the lat. ter to bave much longer (relatively) and more delicate filameuts, and the unopened authers to b. just a little reture at the apex, giving them, when fully opened, the appearanre of a slightly four-lobed disk. 


\section{XEROTIDEA.}

Dasylirion* Graminifolium, $†$ Zucc.-Caudex $4^{\circ}$ high; scape 8-10 high, $2^{\prime}$ in diameter; leaves $2^{\circ}$ long, $6-10^{\prime \prime}$ wide, spiny serrated; spikes of the flowering panicle subtended by lanceolate, clasping bracts; perianth white or whitish; filaments much exceeding the lobes; embryo cylindrical, in the centre of a hard, horny albumen and nearly as long; fruit whitish, with a purple tinge, conspicuously 3-winged.-Soutliern Arizona (329, 655).

Dasylirium erumpens, Torr.-Caudex and scape $6^{\circ}$ high; leaves linear, 2-3 ${ }^{\circ}$ long, 4- $6^{\prime \prime}$ wide at base, and regularly tapering to the tip, semiterete below, channelled above, edges rough; fruit 3-lobed, 3-celled, and not winged (but appearing so from the diverging cells), broader than long, thin, membranous, and burst by the maturing seed; the sheathing bract at base of each primary branch attenuate into a long filiform tip.-Rocky Cañon, Arizona (278).

This my friend Mr. Watson has named Lindheimerianum, but it corresponds so well in its fruit and leaves that I have named it as above.

\section{JUNCEAE.}

\section{By Dr. George Engelimann.}

Juncus Balticus, Deth., $\gamma$. montanus, Engelm. Revis. Junc. in Trans. Acad. Saint Louis, 2, 442.-A smaller inland form of this species, with nearly equal segments of the perigon, longer, beaked capsule, and slender, pointed seeds.-Colorado; New Mexico to Nevada; Rothrock (23).

Juncus triguumis, Linn-Crespitose, with short subulate leaves, channelled near the base; naked stems $3-5^{\prime}$ high, bearing a terminal head of 2 or 3 flowers, enclosed in large broad bracts; obtusish sepals shorter than the oblong, obtuse, mucronate capsule; filaments many times longer than the small anthers; large seeds loosely enveloped in the striated coat, appen-

"DAsyminon, Zucc.-Fl wers diacions. Male-flowers 2-3 in clusters, enclosed in thin, hyuline, somewhat fimbriate bructs; pedicels 1-2" long, jointed above; perianth of 6 similar white or whitish alivisions; filaments attacbed to the base of 1 he divisions; pistil abortive. Female flowers in bracteate clusters, like the males; ovary sometimes 1-, sonetimes 3-celled, with usually 6 orules, of which but one or two mature into secls.-Erect, hard herbs, with clust. rs of narrow, recurved leaves crowuitig the caudex. Scupe 6-14\% high, terminated by large masses of small flowers. The euds of tho leaves nsually split up into white, thin, strong fibres, which could doubtless be utilized in the mannfacture of cordage.

† Dasylirion graminifolium, Znee. Since tho above was put in type, Mr. Watson has determined this plaut to bo a now and clearly distinct species, which he names $D$. Whiceleri. See uote under Table of Orilery, at eml of volume. 
daged at both ends.- Twin Lakes, Colorado (J. Wolf), and generally on the alpine summits of the Rocky Mountains and northward; also in Europe.

Juncus castaneus, Smith - Stems from a ereeping rhizoma, about a span high, naked or with one or two leaves; basal leaves shorter than the stem, rather stout, channelled below, nearly terete upwards; single or few large, few-flowered heads generally from a foliaceous sheath; deep brown flowers $\frac{1}{4}$ long; anthers half as long as filaments; prismatic capsules much longer than flowers ; seeds $\frac{1}{2}$, , or with the appendages $1 \frac{1}{2}{ }^{\prime \prime}$ long.-Mosquito Pass, Colorado, J. Wolf (933), and generally on the alpine heights of the Rocky Mountains, to the northwest coast, and in similar regions of the Old World. A very conspicuous form; flowers aud seeds among the largest in the genus.

Juncus tenurs, Willd.-Throughout Colorado and New Mexico.Rothrock (45), in 1874.

Juncus bufonrus, Linn.-San Luis Valley, Colorado.

Juncus Longistylis, Torr. Bot. Mex. Bound. 223; Engelm. Junc. 453.-Cæspitose, stoloniferous plants, with flat, grass-like leaves, erect stems $1-2^{\circ}$ high, bearing large, few-flowered heads, single or several in an elongated, strict panicle; flowers $2 \frac{1}{2}-3^{\prime \prime}$ long, with ovate-lanceolate, acute sepals, of nearly equal length; anthers much longer than the filaments; prismatic capsule obtuse, mucronate, about as long as sepals; seeds ovate, abruptly pointed at both ends, striate-reticulate.-Rocky Mountains to California; Twin Lakes and South Park, Colorado, Wolf; Santa F'é, Rothrock (1005), with fewer and larger heads, and Ash Creek, Arizona (308), with smaller, few-flowered heads in a panicle $3-5^{\prime}$ long.

Juncus marginatus, Rostk.-Camp Lowell, Arizona, Rothrock (711), the most western locality known for this species. A form with all the sepals acute and aristulate.

Juncus nodosus, Linn., var. Megacephalus, Torr.-San Luis Valley, Colorado, J. Wolf; Rothrock (174), from Zuñi, New Mexico.

Juncus Mertensianus, Bong.--Stems crespitose, from a stout creeping rhizoma, a span to a foot high, weak, compressed, leafy ; leaves compressed from the sides, indistinctly cross-partitioned, mostly auricled at the sheaths;

18 вот 
heads few, rather large, deep brown or blackish; flowers about $2^{\prime \prime}$ long. outer sepals acute, inner mostly shorter and obtuse, mucronate, rarely similar to the outer ones; stamens 6 , or sometimes 3 ; filaments as long as anthers, or longer; ovary and capsule obovate, obtuse, abruptly pointed by the short style; seeds obovate, short-tailed at both ends.-Highest mountains of Colorado; Mosquito Pass; Twin Lakes, Wolf; and northwestward to Alaska.

Juncus xiphioides, E. Meyer, var. montanus, Engelm. Junc. 1. c. 481.-Stems flattened, $\frac{1}{2}-12^{\circ}$ ligh, with laterally compressed, slightly crosspartitioned leaves, mostly auriculate at sheaths; heads few, many-flowered, light or darker brown; flowers smaller than in the last; all sepals acute, inner ones shorter; stamens 6 ; capsule oval, rostrate, about as long as sepals; seeds oblanceolate, and pointed at both ends.

Sierra Blanca, Arizona, Rothrock (808), at 12,000 feet altitude, and through the Rocky Mountains to California and Oregon. Our specimens show only 1-3 heads, but at Zuñi, New Mexico, Dr. Rothrock collected a form $(170)$ over $2^{\circ}$ high, with few- (3-5-) flowered heads in compound panicles; sepals very acute, of equal length; anthers half as long as filaments; capsule (immature) rostrate. This form seems to stand near the original type from the Pacific coast, or to form a transition from it to J. oxymeris.

\section{COMMELYNEE.}

Tradescantia Virginica, L-The narrow-leaved forms $(372,118)$, New Mexico; also Camp Grant, Arizona.

\section{CYPERACE}

Cyperdes Nuttallin, Torr.-A small form, with three stamens and three stigmas.-Sanoita Valley, Southern Arizona (599).

Cyperus inflexus, Muhl.-San Luis Valley, Colorado (979), and Southern Arizona (600 a, 602, 369).

Cyperus SchweinitziI, Torr-Colorado; also Willow Spring, Arizona, at 7,500 feet elevation.

Cyperus cephalanthus, Torr.-Culm sharply 3-angled; angles decidedly rough; sides hispidly pubesent; leaves shorter than the stem, rough- 
margined, 3-4" wide (radical, and toward lower part of the stem); involucre 3-leaved, leaves much exceeding the umbel; 3-4 rays of the umbel erect, many 8-14-flowered spikelets agglomerated into an oblong head; scales ovate, obtuse, 7-9-nerved, sides brown and midrib green; the bracts subtending the spikelets setaceous, nearly as long as the spikelet; achenia triangular-ovate, somewhat shorter than the scales; stigmas 3 ; stamens 3.-Sanoita Valley, Arizona (600, 601).

Cyperus rotundatus, L., var. Hydra, Gray.-Nevada.

Cyperus phymatodes, Muhl. (C. repens, Ell.; Bot. Mex. Bound.).Southern Arizona $(365,400 a)$.

Hemicarpha subsquarrosa, Nees.-A luxuriant specimen from Camp Lowell, Southern Arizona (715). It appears to me as though this genus rests on insufficient foundation, the inner scale being so often reduced to a minimum, and at times is wanting altogether.

Eleocharis palustris, R. Br-Camp Grant, Arizona, furnishes a specimen (380) with the bristles shorter than the achenium; San Luis Valley, Colorado (927, 977).

Eleocharis acicularis, R. Br-Alkaline flats of San Luis Valley, Colorado (928). Bristles twice as long as the achenium.

Scirpus PaUciflorus, Lightfoot.-Twin Lakes, Colorado (926).

Scirpus pungens, Vahl.-Denver (925), and Gila Valley, Arizona, at 3,080 feet elevation (336). Nevada.

Scirpus validus, Vahl.-San Luis Valley (930); Western New Mexico, at 6,500 feet elevation (104, Loew); also Arizona (330 a), with bristles to fruit longer than achenium; and Nevada.

Scirpus maritimus, L.-Nevada.

ERIophorum polystachyon, L.-Twin Lakes (968).

Fimbristylis CaPiLlaris, Gray.-Southem Arizona $(611,624)$. Quite variable in size and in shape of fruit.

Cladium effusum, Torr-Culms nearly terete, $3-7^{\circ}$ high ; elongated, linear leaves acutely sorrate on back and margin; spikes small, several in a cluster, forming large, loose panicles; scales $4-7$, the lowest empty, the top one with a perfect flower, and the one below it with a staminate flower.-Nevada. 
Komresta* scirpisa, Willd-Crspitose, 5-8' high; leaves shorter than the stem, the few small brown spikelets clustered into a short terminal spike; lower flowers are female, and the upper ones male.-Colorado.

Carex† grnocrates, Wormsk.-Mosquito, Colorado (1000); Twin Lakes, Colorado, Professor Wolf.

Carex scirpoidea, MIx.-South Park, Colorado (1002); Mosquito, Colorado; Professor Wolf.

Carex polytrichoides, Muhl.-Twin Lakes, Wolf (1004).

Carex obtusata, Lilij.-South Park, Colorado (1003).

Carex Lyoni, Boott.-Twin Lakes, Colorado (1001).

Carex siccata, Dew.-South Park (1009); Mosquito, Colorado (1008).

Carex Douglasir, Boott.-Santa Fé, N. Mex. (31); Denver (1010). Var. MINOR at Twin Lakes (1011).

Carex Gayana, Desv. $-1-2^{\circ}$ high, slightly scabrous above; leaves 1-2" wide, shorter than the culm; spikes ovate or oblong, of numerons crowded spikelets, the lower sometimes compound, diøcious, or male with a few female flowers, or female with a few male flowers, naked or with one or two clasping setaceous bracts shorter than the spike; perigynia dark chestnut-colored, shining, plano-convex, tapering to a very short conical beak, whitish at the nearly entire orifice, serrate above on the obtuse margins, marked in front toward the somewhat cordate base with a longitudinal furrow and a few nerves, nerveless on the back, the walls thick and spongy; stigmas 2; scale chestnut-colored, more or less hyaline on the margins, ovate-acuminate, cuspidate, longer than the perigynia; achene orbicular, dark chestnut.-Willow Spring, Arizona (232); South Park, Colorado (225, 383, 384, very young). Otto Böckeler, in the Linnæa, vol. 39, p. 54, quotes C. Gayana as a synonym of $C$. divisa, Huds. But the often diuecious spike of Gayana, its few-nerved, furrowed perigynium with

- Kómesia, Willd-" Pereunial berbs, with grass-like leuves, radieal or sheathi.g the stems at the b se. Spikelets sessilo in a terminal spike, simple or rarely brauched at the base, witb a glume-like bract under each spikelet. In each spikelet the lowest glome encloses an ovary with a long trifid style the vext one, or rarely 2 glumes, enclose 3 stanens, and there is often a small rudimentary glume or awn terminating the axis. Some spikelets have only one glume, enclosing an ovary, aud some, near the eut of the spike, bave ouly one glume with 3 stamens."-Beutban's Haudbouk of the British Flora, p. 99.4. of Boston.

Canex. - l'or the foliowing eareful elaboration of this geuns, I am indebtud to Mr. William Ibutt. 
obtuse margins and nearly entire beak, appear to distinguish it from divisa, which has a bidentate, many-striate perigynium, wing-margined above.

Carex marcida, Boott.-Twin Lakes (1012); Santa Fé, N. Mex.

Carex vulpinoidea, Mx.-Tanks 26 miles south of Camp Apache, Arizona (267).

Carex muricata, L.-Santa Fé, N. Mex. (46, is a very small form). Var. Gracilis, Boott (C. Hookeriana, Dew.), South Park, Colorado (1006).

Carex stenophylla, Wahl.-South Park (1012).

Carex tenella, Schk.-Twin Lakes (1016).

Carex canescens, L-Twin Lakes (1017) (1018 possibly C. canescens, Blytt).

Carex echinata, Murray (C. stellulata, Good.) (1018 in part).-Twin Lakes; also (214) from Willow Spring, Arizona, at 7,400 feet.

Carex Liddoni, Boott.-Colorado (1030 and 1031); Mount Graham, Arizona, at 9,000 feet elevation (427). Dr. Boott founded this species on specimens brought from the Columbia River by Dr. Seouler, and noticed its affinity to $C$. arida. It has since been found to have a wide range at the West, and to be very variable, approaching $C$.leporina, $\mathrm{L}$.

Carex leporina, L.-Colorado, Wolf $(1024,1025)$.

Carex festiva, Dew.-Mosquito, Colorado (1020); Mount Graham, Arizona, at $9,0 \backsim 0$ feet (430).

Carex adusta, Boott.-Colorado, Wolf (1028, 1029).

Carex rigida, Good. (C. vulgaris, Fries, var. alpina, Boott.)-Chiricaluua Creek, Arizona ; also Mosquito, Colorado (1035, 1036), Wolf.

Carex vulgaris, Fries.-Twin Lakes, Colorado (1039.)

Carex aquatilis, Wahl —South Park (1034). Var., Twin Lakes (1037, 1038, Wolf), 18' high, very slender, with 1-2 male and 1-2 linearclavate, loosely flowered, exsertly pedunculate female spikes; bracts shorter than the culm; perigynia (very young) obovate, nerveless, abruptly terminated by an extremely short, entire beak, broader and shorter than the lanceolate purple scales which have a pale midrib.

Carex Jamesir, Torr.-Denver, Colorado (1032); Willow Spring, Arizona, at 7,195 feet (216). (No. 245, from Willow Spring, resembles $C$. acuta, L., but the bracts are shorter and the perigynia bidentate.) 
Carex decidus, Boott.-Willow Spring, Arizona, at 7,195 fect elevation (233), Rothrock.

Carex Buxbaumir, Wahl.-Twin Lakes, Colorado (1042).

Carex atrata, L. - South Park (1046). Var. nigra (C. nigra, All.)Oro City, Colorado (1047). Var. ovata (C. ovata, Rudge.)-South Park (1050, 1051). Var. from Mount Graham, Arizona, at 9,000 feet (431), with cylindrical spikes on elongated weak peduncles.

Carex alpina, Sw.-South Park, Wolf (1013).

Carex Parryana, Dew.-Smoothish, 4-18' high; leaves $\mathbf{8}^{\prime}{ }^{\prime}$ wide, with revolute margins, tapering to a long slender point, shorter than the culm; spikes oblong or cylindrical, either single, diøcious, or 1-4, the uppermo:t much the largest, about $1^{\prime}$ long, male, or female with scattered male flowers, the others female; bracts 1-2, slender, the lowest shorter than the culm, w:th connate purple auricles forming a short $\left(1-2^{\prime \prime}\right.$ long) sheath; perigynia triquetrous, broadly ovate or obovate, emarginate, serrate-ciliate on the margins above, about the length of the broadly ovate, obtuse, mucronate, purple scales with hyaline margins; nerves 2, marginal; stigmas 3; achene obovate, triquetrous.-South Park (1040, 1041).

Carex aurea, Nutt.-Twin Lakes, Colorado (1052-1057). Willow Spring, Arizona, at 7,195 feet (215); a tall form, with short bracts.

Carex Rossir, Boott.-Twin Lakes (1058).

Carex capillaris, L.-South Park (1059). Var. elongata, Torr., T'win Lakes (1060).

Carex lanuginosa, Mx--Twin Lakes $(1061,1062)$. Willow Spring, Arizona, at 7,195 feet (241).

Carex aristata, R. Br.-A single specimen without number or ticket.

Carex sp ? (1064), Colorado. Too young to determine.

Carex utriculata, Boott.-Twin Lakes, Colorado (1069) (1068, with more globular fruit, resembling $C$. ampullacca, Good., common in the Eastern States). Var. gLobosa, Olney, Sierra Blanea, Arizona (806).

Carex vesicaria, L., var. alpigena, Fries. (C. saxatilis, L.; C. pulla, Good.; C. Grahamii, Boott.)-6-2t' high, sharply angled, rough above; leaves $2^{\prime \prime}$ wide, shorter than the culm, tapering to a long, triquetrous apex; male spikes 1-2, about $1^{\prime}$ long, female 1-3' long, $3^{\prime \prime}$ wide, oblong or eylin- 
drical, subremote, the lowest peduncled; perigynia shining, pale or purple, oblong-ovate, tapering to a cylindrical bidentate beak, nerveless or faintly nerved, twice the length of the scale; scales purple, with pale midnerve, male oblong obtuse, female ovate acute; bracts leafy, clasping, longer than the culm, evaginate, or occasionally there is below the fertile spikes an empty bract with a vagina $\frac{1}{2}-1^{\prime}$ long; stigmas $2-3$ (1071-1072, 1070).

Drejer, Revista Crítica, p. 57, says that the Greenland specimens of pulla are two or three times larger and more robust than Iceland ones, occurring with 1-3 approximate or very remote round ovate, acutish or elongated cylindrical, obtuse female spikes; with scales obtuse, shorter, or acute, longer than the perigynia; stigmas 2-3. In the Linn. Trans., Dr. Boott states that Lapland specimens in the Linnæan Herbarium and the description in the Flora Lapponica prove C. pulla, Good., to be the original $C$. saxatilis of Linnæus, but that afterwards Linnæus in the Flora Suecica and the Species Plantarum confounded it with C. rigida, Good, which has since with European botanists generally borne the name of saxatilis. Hooker and Arnott in the British Fl. consider C. Grahamii to be a variety of the original saxatilis of Linnæus. Anderson, Cyper. Scand., names it C. vesicaria, var. dichroa. Dr. Boott finally thought it to be the var. alpigena, Fries, of vesicaria.

The following, belonging to the vesicaria group, with immature fruit, do not admit of accurate determination or full description.

Carex sp.?, probably new, $2^{\circ}$ and over high, pale, slender, smooth and spongy at bottom, slightly scabrous above; leaves $3^{\prime \prime}$ wide, much exceeding the culm; male spikes $3-4,1 \frac{7}{8}$ inches long, contiguous (in one specimen male spikes 4 , distant, occupying a space of $4^{\prime}$ on the culm); female spikes $3-4$, oblong cylindrical, $1-2^{\prime}$ long, $\frac{3}{8}$ ' wide, $1-3^{\prime}$ below the male, and $1-5 \frac{1^{\prime}}{2}$ apart, the uppermost sometimes staminate at top and at bottom, the lowest on short peduncles; bract of lower male spike filiform, exceeding its spikelet; bracts of femalc spikes evaginate, clasping conduplicate at base, much longer than the culm; perigynia (very young) widely spreading, ovate, with a rather long, cylindrical, sharply toothed beak, conspicuously nerved; scale 3-nerved, purple, with pale midnerve, the male oblong-linear, obtuse, female lanceolate or lanceolate-ovate, taper- 
ing to a rough point, shorter than the perigynia; 4 specimens of the Expedition collection received from Washington without number or ticket.

Carex sp. $8-1 \frac{1}{2}{ }^{\circ}$ high, smoothish; leaves (broken) $\frac{1}{8}^{\prime}$ wide; bracts evaginate, the lower male filiform, exceeding the spikelet, the female broad, plane, exceeding the culm; male spikes 3-1, overlapping, uppermost 1' long; female spikes $1-2$, oblong or cylindrical, $1^{\prime}$ long, $3^{\prime \prime}$ wide, $1-3^{\prime}$ below the male, 1-2' apart, occasionally with an empty bract 4-8' below the spikes; perigynia (very young) ovate, spreading, tapering to a cylindrical beak, with short teeth, delieately nerved ; stigmas 3 ; seales 3 -nerved, purple, with pale margins and midnorve, the male oblanceolate obtuse, the female lanceolate or ovate, shorter than the perigynia; vagina of empty bract $6^{\prime \prime}$ long.Willow Spring, Arizona, Rothrock (231).

CAREX sp. $?-2^{c}$ high or more, stout, glaucous, smooth and spongy below, slightly scabrous above, and with the leaves thickly nodose-reticulated; leaves $3^{\prime \prime}$ wide, much longer than the culm; male spikes 4 , overlapping, about $1^{\prime}$ long, rarely with a few female flowers at top and at bottom; female spikes $2, \frac{3}{4}-1 \frac{1^{\prime}}{2}$ long, $\frac{3^{\prime}}{8}$ wide, about $9^{\prime \prime}$ below the male, $1-4^{\prime}$ apart; sometimes staminate at top, the lowest on a short peduncle; bracts of the lowest male spike shorter than the eulm, clasping, with connate purple auricles; bracts of the female spikes much longer than the culm, with vaginæ $\frac{1}{8}-1^{\prime}$ long. In the vagina of the lowest spike, the lamina opposite the bract is extended above to an obtuse point. Below the female spikes there is sometimes an empty bract with a vagina 9" long; perigynia (very young) squarrose, broadly ovate, abruptly ending in a stout, cylindrical, obliquely cut, minutely toothed, strongly nerved beak, purple at the orifice; stigmas 3 ; scales 3-nerved, purple, with pale midnerve, the male oblong linear, obtuse, the female lanceolate acute, as long as the perigynia. The pale fruit and purple scales give the female spikes a variegated appearance-Colorado (460).

Carex sp.?-Culm and leaves as in the last; male spikes 3-4, contiguous, the upper 1-2' long, naked or rarely the lower with a filiform, clasping bract exceeding its spikelet; ferti'e spikes 2 , narrow-eylindrical, often staminate to near the base, $1 \frac{1}{2}-2^{\prime}$ long, $1-21^{\prime}$ below the male, and about $2^{\prime}$ apart, sometimes with a lower, $4-S^{\prime}$ distant, empty bract, the upper sessile, the lower 
in a short, included peduncle; perigynia ovate, nerved, tapering to a cylindrical beak, with short teeth; bracts of female spikes evaginate, clasping, or of the empty bract with a vagina $6^{\prime \prime}$ long, exceeding the culm; scales 3-nerved, purple, with pale margins and midnerve, the male linear-oblong, acutish, the female lanceolate, tapering to a sharp rough point, longer than the perigynia.-Saguache Creek, Colorado, Wolf (1065). While the culm, leaves, and male spikes in these specimens are fully developed, the female spikes appear to have been arrested in their growth. In the disposition of the spikes, they resemble aristata, but the short teeth of the perigynia exclude them from that specics.

\section{GRAMINE E.}

\section{By George Vasey, M. D.}

Alopecurus aristula'ids, Michx. - Twin Lakes, Colorado, 1873 (1073); Santa Fe, N. Mex., 1874 (32). Varies much in the length of the awn, which is sometimes shorter, sometimes longer than the palet,- -sometimes, indeed, as in No. 390, Palmer, 1868 , twice as long as the palet, in which case it is hardly to be distinguished from $A$. geniculatus, L., of which it is considered a variety by Steudel. There is an equal variation in the stoutness of the culm.

Phleum alpinum, L.-Twin Lakes and South Park, Colorado, 1873 (1074).

Hilaria* cenchroides, H. B. K-Culms stoloniferous, 1 foot or less high, frequently rooting at the pubescent nodes; leaves flat, narrorvly linear; spike terminal; rachis flattened, flexuous, of $8-10$ joints ; spikelets in threes, which are connate at the base and alternate on the rachis.-Sanoita Valley, Arizona (595).

Vilfa cuspidata, Torr.-Twin Lakes, Colorado, 1873 (1075, 1076). In some specimens, the glumes are acute and in others obtuse; indeed,

- Hrumis, H. B. K.-Panicle spike-like, spikelets sessile, in threes, which are connate at the base, the two anterior ones male and from 1- to 3-flowered, the posterior female and 1-flowered. Male flowers: glnmes 2, unequal, the lower one bifid and aristate, the upper one emarginate and mucronate; palets linear-oblong, emarginate and rounded at the apex, stamens 3.-Female flowers: glumes 2 , opposite, alike, uneqnally 2-lubed, aristate between the lobes; palets 2 , expanded at the base, and abruptly narrowed into a long neck, inferior one 3-nerved, superior one 2-nerved : styles 2; grain oblong, compressed, frec botween the 2 valves. 
there seem to be no good characters to distinguish this from Vilfa depauperata, Torx.

Vilfa minima, Vasey.-Culms erect, 1-1 $\frac{1}{2}$ high, branched at the base, slender; spikes simple, few-flowered, terminal and lateral, the lateral ones partly enclosed in the loose sheaths; flowers alternate, half a line long, pointed; glumes membranaceous, obtuse, about half as long as the flowers; palets nearly equal in length; leaves mostly radical, short $\left(\begin{array}{l}1 \\ 4\end{array}-\frac{1}{2} 2^{\prime}\right)$, strongly nerved; lower sheaths inflated. This diminutive grass appears to be annual, very slender and delicate--On wet, sandy shores around Tivin Lakes, Colorado, 1873 (1077), appears somewhat like $V$. depauperata, var. filiformis, but is distinct-PLATE XXVII. Fig. 7. Plant, natural size. Fig. 8. Flower, magnified 15 diameters. Fig. 9. Cross-section of stem, greatly magnified.

Vilfa (Sporobolus) cryptandra, Torr.-Nevada, Arizona, and Utal, 1871, and 1872 ; Arkansas Valley, 1873 (1078). Var. rlexuosus, Thurb., Nevada and Arizona, 1871 and 1872. In the variety, the panicle is longer and more slender, and the branches are capillary and flexuous.

Vilfa (Sporobolus) airoides, Trin. (Watson's Botany 40th Parallel).Called salt-grass and used for pasturage. Grows in alkaline soil. Nevada, 1871 and 1872; Colorado, 1873 (1079); Deer Springs, Arizona, 1874 (185); Albuquerque, N. Mex., 1874 -(122); Sulphur Springs, Arizona, 1874 $(550)$. The leaves of this species and also of the preceding furnish a strong fibre, which might be utilized in making paper or cordage.

Vilfa (Sporobolus) asperifolia, N. \& M.-Nevada and Utah, 1871 and 1872; Cottonwood Creek, Colorado, 1873 (1081); Saguache Creek, Colorado, 1873 (1082); Sanoita Valley, Arizona, 1874 (692). No. 1082, from Colorado, is a very luxuriant form, in which many of the specimens have 2-3-flowered spikelets. Many of these have the grain affected with a black smut. No. 692 is a long-stemmed, procumbent form.

Vilfa (Sporobolus) ramulosa, H. B. K. (Watson's Botany of the 40th Parallel).-Saguache Creek, Colorado, 1873 (1080).

Vilfa tricholepis, Torr. (Synopsis of Flora of Colorado),-Mount Graham, Arizona, 1874 (745); Sierra Blanea (801). Called bunch-grass in Arizona ; makes an excellent forage (Dr. Rothrock). 
VILFA Rigens, Trin.?-Culm erect, 2-3 high, simple; leaves erect, coriaceous, convolute, pungent; radical ones very long ( $1^{\circ}$ or more); panicle strict, erect, 1-1 $12^{\circ} \mathrm{long}$, interrupted below, the base frequently included in the upper sheath; rays short, appressed, floriferous to the base; spikelets $2^{\prime \prime}$ long, smooth; inferior glume one-fourth shorter than the valve. Arizona, 1871 and 1872 .

Agrostis Perennans, Tuck. ?-Wet ground among the timber; Colorado, 1873 (1085).

Agrostis scabra, Willd.-Low ground, Twin Lakes, Colorado, 1873 (1083) ; South Park, Colorado, 1873 (1084); Willow Spring, Arizona, 1874 (225). A very slender form.

Agrostis exarata, Trin. (Watson's Botany 40th Parallel).-Twin Lakes, Colorado, 1873 (1086); Camp Apache, Arizona, 1874 (258).

Agrostis verticillata, Vill.-Root fibrous, culm procumbent, geniculate at the rooting or ascending nodes, sheaths smooth or pubescent, ligule 1-2" long; leaves lanceolate-linear, 1-3' long, 1-3" broad, scabrous on the margins and above, rarely glabrous; panicle dense, $1-4^{\prime}$ long, more or less interrupted below; rays more or less verticillate (3-8 together), at the base branching and densely floriferous; glumes acute, nearly equal, 1-nerved; palets subequal, awnless, $\frac{1}{3}$ to $\frac{1}{2}$ shorter than the glumes.-Camp Bowie, Arizona, 1874 (449); Central New Mexico, 1874 (114).

Agrostis vulgaris, With.-Twin Lakes, Colorado, 1873 (10\$7); probably introduced.

Munlenbergia disticiophylla, Kunth-Root firm, fibrous; culm erect, 3-4 ${ }^{\circ}$ high, smooth, compressed, sheathed at the base by the distichous, coarse sheaths; leaves very long, rigid, flat or somewhat involute, compressed at the base, scabrous on the margin and keel; panicle often $1^{\circ}$ or more long, contracted; rays solitary, thin, appressed, branched; glumes subequal, scabrous on the back, shorter than the palets; inferior palet 3-nerved, short pilose on the margin below; apex prolonged into a bristle $2 \frac{1}{2}$ to $5^{\prime \prime}$ long; superior palet 2 -nerved. The awn is wanting in some forms.-Rocky Cañon, Arizona, 1874 (282); an awnless form (283).

Munlenbergia Texana, Thurb. (Symopsis of Flora of Colorada, p. 144).-Arizona, 1871 ; Cienega, Arizona, 1874 (574). 
Munlenbergia pungens, Thurb. (Proc. Acad. Plil. 1863, p. 78; Synopsis of Flora of Colorado, p. 144).-Fort Garland, Colorado, 1873 (1088).

Muhlenbergia gracillima, Tort. (Syn. of Flora of Colorado, p. 144).San Luis Valley, Colorado, 1873 (1091).

Muhlenbergin gracilis, Trin. (Steudel, Gram. p. 179).-Root fibrous; culm erect, slender, branching at the base, $8^{\prime}$ to $1 \frac{1}{2}$ or $21^{\circ}$ high, minutely scabrous, as well as the sheaths; leaves erect, narrowly linear, $1-12^{\prime}$ long, plane or convolute, rigid, retrorsely scabrous; panicle contracted, $2-8^{\prime}$ long; branches solitary, appressed; pedicels very short; glumes ovate, the lower 1-nerved and acuminate, the upper 3-nerved and 3-toothed, the teeth awlpointed; palets lance-oblong, " 2 "long, nearly equal, minutely scabrous, or somewhat pubescent on the nerves below, the upper with an awn $2-6$ " long - Twin Lakes, Colorado, 1873 (1089). The species as here defined embraces several varieties, two of which are represented in the collections.

MIuillenbergia gracilis, Trin., var. breviaristata-Cespitose, low (8-1 ¿' high), often growing in ring-like patches; leaves very short, 1-3', involute and rigid; panicle short, $2-3^{\prime}$, very close; awn of the upper palet about its own length.-Twin Lakes, Colorado, 1873 (1098).

Munlenbergia gracilis, Trin., var. Major.-Culm tall, 2 to $22^{\circ}$, slender; leaves 6 to $8^{\prime}$ long; panicle 6 to $8^{\prime}$ long, lax, strict; glumes half as long as the palcts; palets equal, minutely scabrous; awn 3-4 times as long as the palet-Mount Graham, Arizona, 1874 (744). These forms seem to be sufficiently distinct for species, and may have been described under other names.

Muhlenbergin syldatica, T. \& G., var flexuosa, Vasey, perhaps a new species. It is $731, \mathrm{C}$. Wright, New Mexico.-Culms about $2^{\circ}$ long, slender, branching from the base and the lower half of the culm, the branches also floriferous; leaves narrow, $3^{\prime}$ long; panicle graceful, drooping, loose, somewhat contracted above, 3-5' long; branches mostly single (below somewhat distant), lower ones $1 \frac{1}{2}^{\prime}$ long, divided, and flowering to the base; pedicels very short; glumes $\frac{2}{3}$ to $\frac{3}{4}$ the length of the flower, scarious, lanceolate, acute, 1 -nerved, shortly 2 -toothed, or with 1 or 2 short hairs (setæ) at the apex, scabrous on the midrib; palets conspicuously 
pubescent below, especially on the nerves, nearly equal, lower one 3-nerved, upper 2-nerved; awn 7 to $10^{\prime \prime}$ long. Panicle looser and awns longer than in M. sylvatica.-Camp Crittenden, Southern Arizona, 1874 (681).

Vaseya comata, Thurb. (Watson's Botany 40th Parallel).-Gravelly shores, Twin Lakes, Colorado, 1873 (1092).

Calamagrostis Canadensis, L., var. robusta.-A robust form, approaching C. Langsdorffi, Trin.-Twin Lakes, Colorado, 1873 (1093).

Calamagrostis stricta, Trin.--Twin Lakes, Colorado, 1873 (1096). Saguache Creek, Colorado, 1873 (1097).

Calamagrostis stricta, var. robusta.-Culms $2^{\circ}$ high, stout, scabrous, as are the leaves and sheaths; leaves erect, 10-15' long, plane or somewhat involute, slender pointed; panicle strict, rigid, rather dense; spikelets larger and coarser than in the preceding. This approaches $C$. confinis.-It occurs in many collections from the Rocky Mountain region. Twin Lakes, Colorado, 1873 (1099). Some specimens are affected with an ergot $(1 ; 01)$.

Calamagrostis stricts, var. brevior-Very near the preceding variety, but with shorter, more rigid culms, and panicle partly included in upper sheath. This was in an earlier report referred to C. Lapponica, Trin.-Mosquito, Colorado, 1873 (1098).

Calamagrostis syltatica, DC. (Watson's Botany 4rth Parallel, Synopsis of Flora of Colorado).-Mosquito, Colorado, 1873 (1094); South Park, Colorado (1095).

Eriocoma cuspidata, Nutt. (Watson's Botany 40th Parallel, Synopsis of Flora of Colorado).-Nevada and Arizona, 1871 and 1872; Denver, Colorado, 1873 (1102).

Oryzopsis micrantha, Thurb. (Synopsis of Flora of Colorado).Santa Fé, N. Mex., 1874 (44).

Stipa avenacea, L.-Camp Grant, Arizona, 1874 (456).

Stipa comata, Trin. (Watson's Botany 40th Parallel).-Agua Azul, N. Mex., 1874.

Stipa spartea, Trin.-Utah, 1871 and 1872; Twin Lakes, Colorado, 1873 (1103).

Stipa viridula, Trin. (Watson's Botany 40th Parallel, Synopsis Flora 
of Colorado).-Twin Lakes, Colorado, 1873 (1104); Arkansas Valley (1105); Mosquito, Colorado (1106); alpine woods, Colorado (1107 and 1108).

Stipa Mongolica, Turez. (Watson's Botany 40th Parallel, Synopsis of Flora of Colorado). -Twin Lakes, Colorado, 1873 (1100).

Sripa pennata, L., var.-This species, of which little was collected, is easily distinguished by the awns, which are 6 inches or more long, twisted for $1 \frac{1}{2}-2$ inches below, the upper part flat and beautifully plumosepennated.-Arizona. Locality not recorded.

Stipa occidentalis, Thurb. (Watson's Botany 40th Parallel).-Nevada, 1871 and 1872.

Aristida purpurascens, Poir--Arizona, 1871 and 1872.

$\Lambda$ ristida purpurea, Nutt. (Watson's Botany 40th Parallel, Synopsis Flora of Colorado)-Camp Bowie, Arizona, 1874 (481); Camp Grant, Arizona, 1874 (374).

Aristida purpurea, Nutt., var. longiseta. (A. longiseta, Steud.)-Perhaps a distinct species.-Denver, Colorado, 1873 (1110); Santa Fé, N. Mex., 1874 (1).

Aristida Humboldtina, Trin. (A. divaricata, H. B. K.)-Root fibrous; culms cæspitose, erect, simple, $1-2^{\circ}$ high ; leaves convolute, rather short and rigid; panicle about $1^{\circ}$ long, sheathed at the base, rays rather rigid, in twos or threes, mostly long $\left(3-6^{\prime}\right)$, flower bearing above the middle, inferior ones erect, superior ones open or spreading, most of the branchlets with 2-3 spikelets each; glumes equal or nearly so, acute or awlpointed, 5-6" long, purplish, equal to the flower or slightly longer; palet scabrous; awns sub-equal, middle ones about $8^{\prime \prime}$, lateral ones 4-5" long.Cottonwood, Arizona, 1874 (348).

Spartina gracilis, Trin. (Watson's Botany 40th Parallel, Synopsis Flora of Colorado).-Nevada, 1871; Saguache, Colorado, 1873 (1111).

Pleuraphis Jamesir, Torr. (Watson's Botany 40th Parallel, Synopsis Flora of Colorado).-Arizona, 1871 and 1872; Santa Fé, N. Mex., 1874 (17); Agua Azul, N. Mex., 1874 (132).

Bouteloua curtipendula, Gr--Arizona, 1871 and 18i2; Camp Crittenden and Cienega, Arizona, 1874 (284, 586, 677). 
Bouteloua gracilis, Hook.?-Low, 6-12', densely crspitose, much branched at the base; leaves short $\left(1-2^{\prime}\right)$, flat; spike with 6-10 slender spikelets, about $\frac{1^{\prime}}{2}$ long, nearly sessile, with two to three sterile flowers or bractlets, one perfect flower, and a rudiment which is 3 -awned and longer than the perfect flower. This species is related to $B$. curtipendula, but much smaller and more delicate-Riley's Well, Arizona, 1874(701). [A sparse but good forage.-J. T. R.]

Bouteloua polystachya, Benth.-Culms low, cæspitose (about 6-12'), smooth; leaves $\mathbf{1}^{\prime}$ long, acute, ciliate at the top of the sheath; racemes numerous, graceful; spikes $2-5$, subsessile, 4-6" long, erect; spikelets $\frac{1}{2}$ to 3' long; rachis compressed, margin minutely puberulent; flowers in two series on the rachis; glumes hyaline, lower one small, upper one with a short awn; palets 2-lobed, the lower with 3 awns, upper with 2, rudiments with 3 awns, which equal those of the flower-Arizona, 1871 and 1872 ; Gila Valley, 1874 (770, 352).

Bouteloua POLYSTACHYA, var. MAJOR?-I use this name provisionally to designate a grass larger in all its parts than the preceding. Culms $1-1 \frac{1}{2}^{\circ}$ ligh; racemes with mostly 5-7 spikelets, which are about $1^{\prime}$ long, rather on one side of the culm, sessile or nearly so, about $1^{\prime}$ distant; culms somewhat branched below, rather leafy; leaves flat, 3-4' long, scabrous on the margin. Probably this has been described as a distinct species.-Sanoita Valley, Arizona, 1874 (691, 347).

Bouteloua Humbozdiana, Griseb. ?-Under this name I have placed specimens from New Mexico, because of their correspondence to Cuban specimens of that name in the Herbarium. I do not know where the description is given. The grass is about $1 \frac{1}{2}^{\circ}$ high, upper leaf very short; raceme $2-3^{\prime}$ long, of 4-6 spikes, each of which is about $\frac{1^{\prime}}{2}$ long, wide at the top, tapering: below, of 4-6 long awned spikelets.-Camp Bowie, Arizona, 1874 (484).

Bouteloua juncifolia, Lag.-Culms $1 \frac{1}{2}-2^{\circ}$ high, much branched below, leafy; leaves broadly linear-lanceolate, 4-6' long, rather stiff, smooth panicle or raceme of 6-12 distant, rather coarse spikes, $\frac{1}{2}-\frac{3^{\prime}}{4}$ long, each of 5-7 spikelets; glumes lanceolate, nearly as long as the perfect flower, acute, scabrous on the mid-nerve; lower flower perfect, upper ones staminate; lower palets of perfect flower tridentate, its terminal awn 
little exceeding the palet, lower palet of sterile fl. with 3 long, coarse awns $3^{\prime \prime}$ long (2024, Coll. C. Wright, N. Mex., 1851)-Camp Bowie, Arizona, 1874 (484 bis).

Bouteloua oligostachya, Torr.-Utah, 1871 and 1872. Twin Lakes, Colorado, 1873 (1113). Sulphur Springs, Arizona, 1874 (548).

Boutelous nirsuta, Lag.-Chiricahua, Arizona, 1874 (512).

BoutELoUA FEna, Torr.-Leaves glabrous; spikes 2-3, oblong, falcate, spreading; rachis nearly half the length of the spikes; upper glume nearly as long as the perfect flower, with two rows of piliferous glands on the back; lower palets deeply 3-cleft, the segments lanceolate and mucronate, liairy on the margin, neutral flower of two truncate emarginate valves, with a 2-valved rudiment of a third flower, and 3 short, stout awns (Torrey in Emory's Report).-Arizona, 1871 and 1872.

Chloris alba, Presl.-Spikes umbellate-fasciculate, numerous (8-12), the peduncle enclosed in a broad, compressed sheath; spikelets 2-flowered; upper glume nearly as long as the flowers, 2-toothed, with a short awn between the teeth; lower palet of the perfect flower obscurely 3-nerved, gibbous in the middle, the margin ciliate, with long hairs toward the summit; awn 3 times as long as the palets; neuter flower broad and truncate, enclosing a short aristiform rudiment (Torrey in Emory's Report).Nevada and Arizona, 1871 and 1872. Cienega, Arizona, 1874 (578).

Buchloe dactyloides, Eng. (Synopsis Flora of Colorado).-Summit, Colorado, 1873 (1115)

Tricuspis pulchelra, Torr - A beautiful little grass, with densely cæspitose culms and few-flowered panicles, which are crowded among the fasciculate leafy branches (Torr.). Leaves plane, subulate rigid, scabrous; panicles subspicate, terminating the leafy branches; spikelets 6-7-flowered; glumes lanceolate, acuminate, smooth, equal; lower valve oblong, whitehairy along the middle and base, apex bifid, awned between the lobes; awn straight, exceeding the lobes; upper valve oblong, acute-Arizona, 1871 and 1872. Cienega, Arizona, 1875 (575).

Graphephorum fleducsum, Thurb. (Synopsis of the Flora of Colorado).-Fort Garland, Colorado, 1873 (11:6).

Keeleria cristata, Pers.-Chiricahua, Arizona, 1874 (516). 
Eatonia obtusata, Gr.-Utah, 1871 and 1872. Cave Spring, Arizona, 1874, and Zuñi (194).

Melica mutica, Walt., var. glabra.-Sierra Blanca, Arizona, $1874(805)$.

Melica stricta, Bol. (Watson's Botany 40th Parallel).-Nevada, 1871 and 1872.

Melica bulbosa, Gey. (Synopsis Flora of Colorado).-Nevada, 1871 and 1872.

Glyceria nervata, Trin.-Twin Lakes, Colorado, 1873 (1121). Santa Fé, N. Mex., 1874 (71). A large form, Mount Grahain, Arizona, 1874 (428).

Glyceria aIRoides, Thurb. (Synopsis of Flora of Colorado).-Saguache Creek, Colorado, 1873 (1120).

Glyceria distans, Wahl.-Santa Fé, N. Mex, 1874 (34).

Brizopyrum spicatum, Hook., var strictum, Gr.-Nevada and Utah, 1871 and 1872. Saguache Creek, Colorado, 1873 (1123 and 1124). Covero, N. Mex., 1874 (105). Alcadonis, N. Mex. (84).

Catabrosa aquatica, Beauv. (Synopsis Flora of Colorado, Watson's Botany 40th Parallel).-Near Gray's Peak, Colorado, 1873 (1122).

PoA alpina, L. -Mosquito, Colorado, 1873 (1126). South Park, Colorado, 1873 (1127). This I take to be the true alpina, characterized by the short ovate panicle, and the broad, flat, thick and short, radical leaves.

Poa Andina, Nutt.-Culms tufted, erect, rigid, smooth or scabrous, $6^{\prime}$ to $2^{\circ}$ high, leafy at the base; leaves rigid, scabrous, flat or usually ronvolute, generally glaucous, cauline ones with very short or almost obsolete blades; panicle usually narrow, spike-like and close, or oblong and somewhat expanded, 2-5' long; rays chiefly in threes, almost sessile, or short-stalked; spikelets about $3^{\prime \prime}$ long, ovate, 3-5-flowered; glumes nearly equal, acute, about $2^{\prime \prime}$ long, smooth, hyaline and (generally) purpletinged, except on the keel, compressed, 1-nerved, or the upper indistinctly 3-nerved and broadest at the middle; flowers compressed and keeled, not webbed at the base ; lower palet 2-21" long, obtuse or acutish, indistinctly or plainly 3-nerved; keel curved, scarious and generally purplish above, very light green below, smooth or softly puberulent, except on the keel and margins, which are more or less pubescent. . This grass, which 19 вот 
is supposed to be the Poa Andina of Nuttall, is exceedingly variable and puzzling. It embraces several varieties, two of which are represented in this collection, viz: Var. spicata.-Radical leaves rigid, involute, scabrous, pungently pointed, 3 to $9^{\prime}$ long; panicle narrow and spike-like; branches sessile or nearly so.-Colorado, $1873(1135,1136,1137)$. Var. MA.Jor.Panicle oblong; branches short ; flowers larger and paler-Arizona, 1872; Colorado, 1873 (1133, 1134).

Poa tenuifolia, Nutt. (Watson's Botany 40th Parallel, Synopsis Flora of Colorado).-This species presents a great variety of forms, some of which may yet require to be made distinct species. The general characters may be stated as follows: culms tufted, $1-2 \frac{1}{2}^{\circ}$ high, stout or slender, glabrous or with the leaves and sheaths more or less scabrous; leaves narrowly linear, 1-10' long, ligule short or elongated; panicle erect or slightly bending, narrow or somewhat open and spreading, 2-6' long; branches 2-5 together, scabrous, of unequal length; spikelets 2-5-flowered, glumes keeled, lanceolate or ovate-lanceolate, acute, scarious-margined, upper one 3-nerved, lower 1-nerved; flowers very narrow, linear or linear-lanceolate, scarcely keeled, convex on the back, obtuse or acutish, scarious, and bronze-tinged at the apex, puberulent or finely pubescent, obscurely nerved, not webbed; flowers readily separating at the joints. The grain is extensively gathered by the Indians for food. The following forms or varieties occur in the collection: Var. RIGIDA, Nevada, 1872, Colorado, 1873 (1138 and 1140); var. Elongata, panicle linear, 5-6 inches long; Nevada, 1872; Colorado, 1873 (1141).

Poa pratensis, L.-Colorado, 1873 (1125); Santa Fé, N. Mex., 1874 (19); and, what seems to be a slender form, in bogs, Twin Lakes, Colorado, 1873 (1131).

Poa serotina, Ehrh.-Twin Lakes, Colorado, 1873 (1130); also var. raxicaule, Twin Lakes, Colorado, 1873.

PoA CEsIA, Sm. ?, var. RIGIDA.-Mosquito, Colorado, 1873 (1142); South Park, Colorado, 1873 (1143).

Pos laxa, Hænke?-Colorado, 1873 (1128). Var. minor, Hall's post-office, Colorado, 1873 (500, J. Wolf).

Poa flexuosa, var. occidentalis.-Twin Lakes, Colorado, 1873 
(1132). Culm 2-3 ${ }^{\circ}$, erect, rather stout; culm-leaves broadly linear $\left(3-5^{\prime}\right.$ long, $3^{\prime \prime}$ broad), gradually tapering to a point, rather scabrous; sheaths mostly smooth, shorter than the internodes; panicle $4-8^{\prime}$ long; rays $2-5$ together, mostly in twos or threes, $2-3^{\prime}$ long, and capillary, smooth or slightly scabrous, diverging, flower-bearing mostly for the upper third; spikelets 3-5-flowered, light green, rather loose; glumes acute, thin, smooth, except slightly hispid on the keel, obscurely nerved; lower palet distinctly 3-5-nerved, slightly pubescent, rather more so on the keel and margin below, acutish.

PoA Wheeleri, Vasey.-Culms $1 \frac{1}{2}-2$ feet high; radical leaves rigid, involute and cuspidate-pointed, 5-10 inches long; culms from running rootstocks like Poa brevifolia, Muhl., and having a panicle like that with capillary branches in pairs ; flowers acute, not webbed.-South Park, Colorado, 1873 (1131).-Plate XXVIII. Fig. 1. Natural size. 2. Spikelet, magnified 5 diameters. 3. Upper floret, with rudiment, magnified 7 diameters.

PoA A Rctica, R. Br.-Culms $1 \frac{1}{2}-2^{\circ}$ high, erect, slender, very smooth, as are the sheaths and leaves; leaves about 2 on the culm, $2-3^{\prime}$ long, narrow-linear; panicle $4-5^{\prime}$ long; rays simple or in pairs, capillary, lower ones $2-3^{\prime}$ long, rather distinct, spreading and reflexed with age, branched near the extremity with few spikelets; spikelets mostly 3-flowered; glumes broadly ovate, rather acute, purple-margined; flowers ovate, acute, obscurely 3-5-nerved, smooth, except pubescent on the keel and lateral nerves, slightly webbed.-Along mountain streams. Twin Lakes, Colorado (1144 and 1145).

Eragrostis Purshit, Bernh.?-Nevada, 1871 and 1872; Camp Lowell, Arizona, 1874 (1004).

Eragrostis pilosa, Beauv.-Saguache Creek, Colorado, 1873 (1146).

Eragrostis pozoides, var. megastachya, Beauv.-Ash Creek, Arizona, 1874 (305). Var. foliosa, Cienega Creek, Arizona, 1874 (591).

Festuca ovina, L-Utah, 1871 and 1872 ; Colorado, 1873 (1149).

Festuca ovina, L., var. duriuscula.-Twin Lakes, Colorado, 1873 (1150).

Festuca ovina, L., var.-Mount Graham, Arizona, 1874 (424).

Festuca ovina, L., var. aristata.-South Park, Colorado, 1873 (1148). 
Festuca ovina, L., var. tenuifolia.-South Park, Colorado, 1873 (1151).

Festuca ovina, L., var. BRevifolia, Watson.-Mount Lincoln, Colorado, 1873 (1152).

Festuca tenells, Willd-Denver, Colorado, 1873 (1147); Santa Fé, N. Mex., 1874 (74).

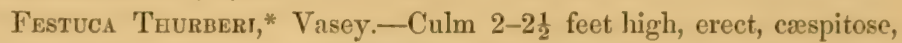
smooth, 2-4-leaved; leaves rigid, involute, $6^{\prime}$ long, scabrous ; radical leaves numerous, involute, rigid, $1-1 \frac{1}{2}^{\circ} \mathrm{long}$, very scabrous on the margin, sheatlıs somewhat membranaceous; blade deciduous when old; panicle compound, $3-5^{\prime}$ long, a little drooping, of $4-5$ nodes; branches or rays single or in pairs, slender, 2-4' long, spreading when ripe, branching at or below the middle; spikelets purplish, oblong-lanceolate or cylindrical when young, broad above when expanded, 3-5-flowered, 5-6" long, slightly scabrous under the lens; glumes thin, membranaceous, $\frac{1}{3}$ shorter than the flowers, of nearly equal length $\left(2^{\prime \prime}\right)$, obtuse or acutish, upper one convex, not compressed, obscurely nerved, lower one slightly keeled; flowers cylindrical, convex, not compressed; outer palet obscurely 5-nerved, $3^{\prime \prime}$ long, lanceolate, acute or short cuspidate, minutely scabrous; inner palet narrow, slightly hispid on the keels, equalling the outer, sometimes bifid at the apex.

This species in several preceding collections from the Rocky Mountnins has been called Festuca scabrella, Torr., but upon careful comparison of the figure and description of that species in Hooker's Fl. Bor. Am., I am satisfied that this is a different species.-Twin Lakes, Colorado, 1873 (1153); South Park, Colorado (1154).-Plate XXIX. Natural size. Fig. 1. Spikelet, magnified 5 diameters. 2. Upper glume. 3. Lower glume. 4. Upper palet. 5. Lower palet.

Bromus ciliatus, L., var. Purgans?-Utah, 1871 and 1872; Twin Lakes, Colorado, 1873 (1155 and 1156); Sierra Blanca, Arizona, 1874 (802).

Var. montanus.-Twin Lakes, Colorado, 1873 (1157); Mount Graham, Arizona, 1874 (435).

Bromus Breviaristatus, Thurb. ? (Watson's Botany 40th Parallel).-

" [See, also, Botanical Gazette, vol. 2, No. 1.-J. T. R.] 
Near Gray's Peak, Colorado, 1873 (1158). This differs somewhat from the plant described by Hooker, but is probably only a local variety.

Puragmites сомmunis, L-Utah; 1871 and 1872.

Lepturus paniculatus, Nutt.-Denver, Colorado, 1873 (1178); San Carlos Creek, Arizona, 1874 (777).

Triticum Repens, L.-Nevada and Utah, 1871 and 1872; Twin Lakes, Colorado, 1873 (1166); Santa Fé, N. Mex., 1874 (35); Agua Azul, 1874 (103).

Var. TENerum.-Cave Springs, Arizona, 1874 (195).

Var. glaucum.-Cottonwood Creek, 1873 (1167).

Var. сомрастuм.-Twin Lakes, Colorado, 1873 (1168 in part).

Triticum violaceum, Hornem.-Culms erect, $2^{\circ}$; leaves rather rigid, erect, inclined to be convolute; panicle erect, $4-5^{\prime}$ long; spikelets $3-5-$ flowered; glumes tapering into an awn longer than the body, 5-7-nerved; lower palet obscurely 5-nerved, with an awn longer than the palet, the upper one obtuse, ciliate on the margins; flowers more or less tinged. Perhaps only a form of T. Caninum, L.-Twin Lakes, Colorado, 1873 (1168).

Triticum caninum, L.-Twin Lakes, Colorado, 1873 (1169).

Hondeum jubatum, L.-Nevada and Utah, 1871 and 1872 ; Saguache, Colorado, 1873 (1164).

Hordeum Pratense, Huds.-South Park, Colorado, 1873 (1165).

Elymus Canadensis, L.-Utah, 1871 and 1872 ; Rocky Cañon, Arizona, 1874 (297); Chiricahua, Arizona, 1874 (526).

Elymus Sitanion, Schultz (Watson's Botany 40th Parallel, Synopsis Flora of Colorado).-Denver, Colorado, 1873 (1161); South Park, Colorado (1163); Twin Lakes, Colorado, 1873 (1162); Arizona, 1874.

Elymus condensatus, Presl (Watson's Botany 40th Parallel, Synopsis Flora of Colorado).-Nevada and Utah, 1871 and 1872; Grant Creek, Colorado 1873 (1160).

Danthonia Sericea, Nutt.-Twin Lakes, Colorado, 1873 (1170); also a small form, which is perhaps D. SPICATA, South Park, Colorado, 1873 (1171).

Trisetum subspicatum, Beauv.-North Pass, Colorado, 1873 (1172); Baker's Mine, Colorado, 1873 (1173). 
Trisetum alpestre, Beauv.-This is chiefly distinguished from $T$. subspicatum by its slender, open, spreading panicle. It corresponds well with European specimens of $T$. alpestre.-Twin Lakes, Colorado, 1873 (1174).-Plate XXVII. Fig. 4. Natural size. 5. Spikelet, magnified 6 diameters. 6. The same, with glumes removed. The figure should have shown a slight pubescence on the pedicel of the upper floret.

Trisetum Wolfir. - Culms erect from a decumbent base, $1 \frac{1}{2}-2^{\circ}$ ligh, smooth above; leaves flat, upper ones short, lower ones $4-6^{\prime}$ long, somewhat scabrous, ligule lacerate; flowers in an upright, elose, almost spicate panicle, which is $2-4^{\prime}$ long, 1-2 rays at each joint; spikelets lanceolate, 2-flowered, and with rudiment or continuation of the rachis half as long as the upper flower, the rachis and filament villous; glumes lanceolate, membranaceous, acuminate, equalling the flowers, which have a few hairs at the base; lower palet lanceolate, acuminate, slightly split or 2-toothed at the apex, obscurely 5 -nerved, bearing near the point a straight appressed awn, equalling or a little exceeding the palet; upper palet rather shorter; grain oblong-linear, nearly as long as the palets. This obseure grass was collected by Mr. E. Hall in the Rocky Mountains, and in his collection was mixed with Poa tenuifolia; it was also collected by the writer in 1868, on the expecition of Major Powell, and distributed as No. 693 in his collection. Very fine specimens were also collected in Middle Park, Colorado, in 1874, by Prof. G. H. French. It is at least very close to, if not identical with, Graphephorum melicoides, some specimens of which from Mount Kineo, Maine, show the short awn on the lower palet.Twin Lakes, Colorado, 1873-Plate XXVII. Fig. 1. Natural size. ¿. Spikelet, magnified 5 diameters. 3. A floret, showing the palets and the linear seed, enlarged 5 diameters.

Aira cespitosa, L., var. Montana.-The Rocky Mountain forms of this species vary from the description in having involute instead of flat leaves, but rather thick and coarse, unlike the bristle-form leaves of $A$. flexuosa, and usually also in having longer awns than are described.-Utal, 1871 and 1872. South Park, Colorado, 1873 (1175). Willow Spring, Arizona, $1874(230)$.

IIterochloa borealis, R. \& S.-South Park, Colorado, 1873 (1176). 
Beckmannia erucerformis, Host. (Watson's Botany of 40th Parallel, Synopsis Flora of Colorado).-Saguache Creek, Colorado, $18 i 3$ (1177). Zuñi, N. Mex., 1874 (163).

Panicum oвtusum, H. B. K.-Culms erect, about $18^{\prime}$ high, rather rigid; leaves linear, rigid, 3-6 long; sheaths smooth; panicle erect, 5-6 long, of 5-7 appressed branches; spikelets in pairs, sub-imbricated, obovate, obtuse, smooth; inferior flower of $\mathbf{2}$ palets, triandrous; perfect flower narrow, longitudinally striate. Plant glabrous and somewhat glaucous. Rachis narrowly linear, very flexuous.-Sulphur Springs, Arizona, 1874 (549).

Panicum maximum, var. Bulbosum, Jacq.-Root bulbous; culm erect, $3-4^{\circ}$ high, rather wiry, naked above, glabrous; leaves narrowly linear, erect, 3-4' long, smooth, or somewhat scabrous; panicle 3-6' long, strict; rays mostly single, strict, distant, branched to the base, sparsely flowered; spikelets mostly sessile, or very short peduncled, ovate, acutish; glumes thin, purplish, obtuse, the lower about half as long as the perfect flower, upper one 5-nerved; sterile flower of two thin palets; perfect flower ovate-oblong, smooth.-Rocky Cañon, Arizona, 1874 (296 and 298).

Panicum Crus-galli, L.-Camp Crittenden, Arizona, 1874 (668).

Panicum Leucophedur, H. B. K. ( $P$. lachnanthum, Torr.) - Culm ascending, branched below, glabrous, $1 \frac{1}{2}-2^{\circ}$ long; leaves flat, 4- $6^{\prime}$ long; sheaths hairy; panicle oblong, erect, $3-6^{\prime}$, the branches alternate and loosely racemose; all the spikelets pedicellate, oblong; inferior glume very short, glabrous; the superior and the inferior palet of the abortive flower much attenuate and somewhat awned at the tip, densely covered with very long, white, silky hairs; perfect flower ovate-lanceolate, acuminate and mucronate, glabrous, finely striate, and dotted longitudinally.-Arizona, 1871 and 1872. Camp Bowie, Arizona, 1874 (489).

Setaria caudata, R. \& S.-Culm erect, $2^{\circ}$, flattened below, leafy; leaves and sheaths retrorsely scabrous, flat, hairy at the mouth of the sheath, upper leaves involute-pointed; panicle cylindrical, 4-6' long, dense or loose and interrupted, pale green; spikelets glomerate, oblong, acutish, $1^{\prime \prime}$ long; glumes herbaceo-membranaceous, cordate, mucronulate, lower one $\frac{1}{3}$ to $\frac{1}{2}$ as long as the upper, upper one 5-7-nerved, perfect flowers ovate, acute, finely punctate; bristles upwardly serrulate, 
4-6" long.-Gila Valley, Arizona, 1874 (334). Var. Padcirlora much smaller and more delicate; leaves broader and shorter and not scabrous; panicle much smaller and looser, is 2096, C. Wright, N. Mex. Coll., 1851 and 1852 .

Helopus punctatus, Nees.-This differs from Panicum in having clavate, torulose pedicels, and in the absence of the inferior glume. Culm erect, $2-3^{\circ}$ from a decumbent base, somewhat pubescent at the nodes, ligule a short pubescent fringe ; leaves lanceolate-linear, $6-10^{\prime}$ long, $3-5^{\prime \prime}$ wide, smooth; panicle $6^{\prime}$ long, of 5-10 erect, sessile branches; axis and rays pubescent; pedicels clavate, with a short ring-like torus; spikelets $1 \frac{1}{2}-2^{\prime \prime}$ long, acuminate, finely pubescent; glume and sterile flower pointed; perfect flower oval or oblong, mucronulate, punctate.-Cienega, Arizona, 1874 (583).

Andropogon macrourus, Michx.-Southern Nevada and Arizona, 1871 and 1872.

Andropogon ARgenteus, Ell--Arizona, 1871 and 1872. Sulphur Springs, Arizona, 1874 (547).

Andropogon scoparius, Michx-Black River Flats, Arizona, 1874(790).

Andropogon ciltaris, Trin. (Elionurus ciliaris, H. B. K.) -This belongs to a section of Andropogon which is distinguished by having the spikes solitary, lateral, and terminal. Root fibrous, red, aromatic ; culms crespitose, ascending or erect $\left(3-4^{\circ}\right)$, compressed; ligules short, ciliate; leaves narrowly linear or filiform-involute, glabrous, or pilose below ; spikes $2-4^{\prime}$ long, jointed; male spikelet with a short, ciliate, margined pedicel; perfect spikelet sessile, the lower glume acutely bifid at the apex, white hairy externally.-Sanoita Valley, Arizona, 1874 (638).

Andropogon contortus, L. (Heteropogon hirsutus, Pers.) - This belongs to the same section as the preceding. Culm erect, branching, 1-2 $2^{\circ}, 2-$ edged below; sheaths and nodes glabrous; ligule short, truncate, ciliate; leaves flat, slarp-pointed, scabrous; spikes solitary; rachis and pedicel of the fertile flowers hirsute; outer glume of male flower acute and pilose; awn long $\left(3^{\prime}\right)$.- Sanoita Valley, Arizona, 1874 (656).

Sorghum nutaks, Gr.-Sanoita Valley, Arizona, 1874 (689).

Imperata Arundinacea, Cyrill.-Spikelets in pairs, one sessile, the other 
pedicelled, all fertile, articulate at the base; glumes 2, membranaceous, subequal, awnless, externally covered with long silky hairs; inferior flower of 1 hyaline palet; superior flower perfect, of 2 minute, hyaline, awnless palets; stamens 2, styles 2, elongated; stigmas plumose; panicle contracted, spike-form, cylindrical; spikelets externally surrounded with long silky hairs; culm erect, $2-3^{\circ}$, and with the nodes and the leaves glaucescent and smooth; leaves linear, setaceo-acuminate ( $1^{\circ}$ or more long, $2^{\prime \prime}$ wide), rigid; panicle elongated-cylindrical, 4-8'. - Nevada, 1871 and 1872; Sanoita Valley, 1874 (656). 
1

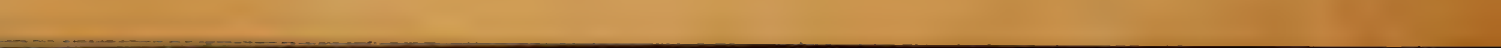



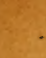

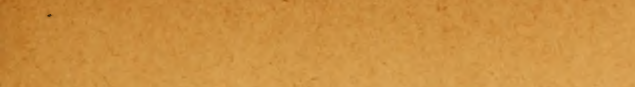

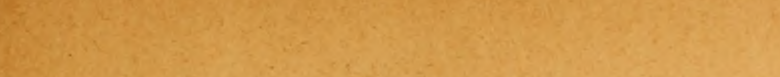





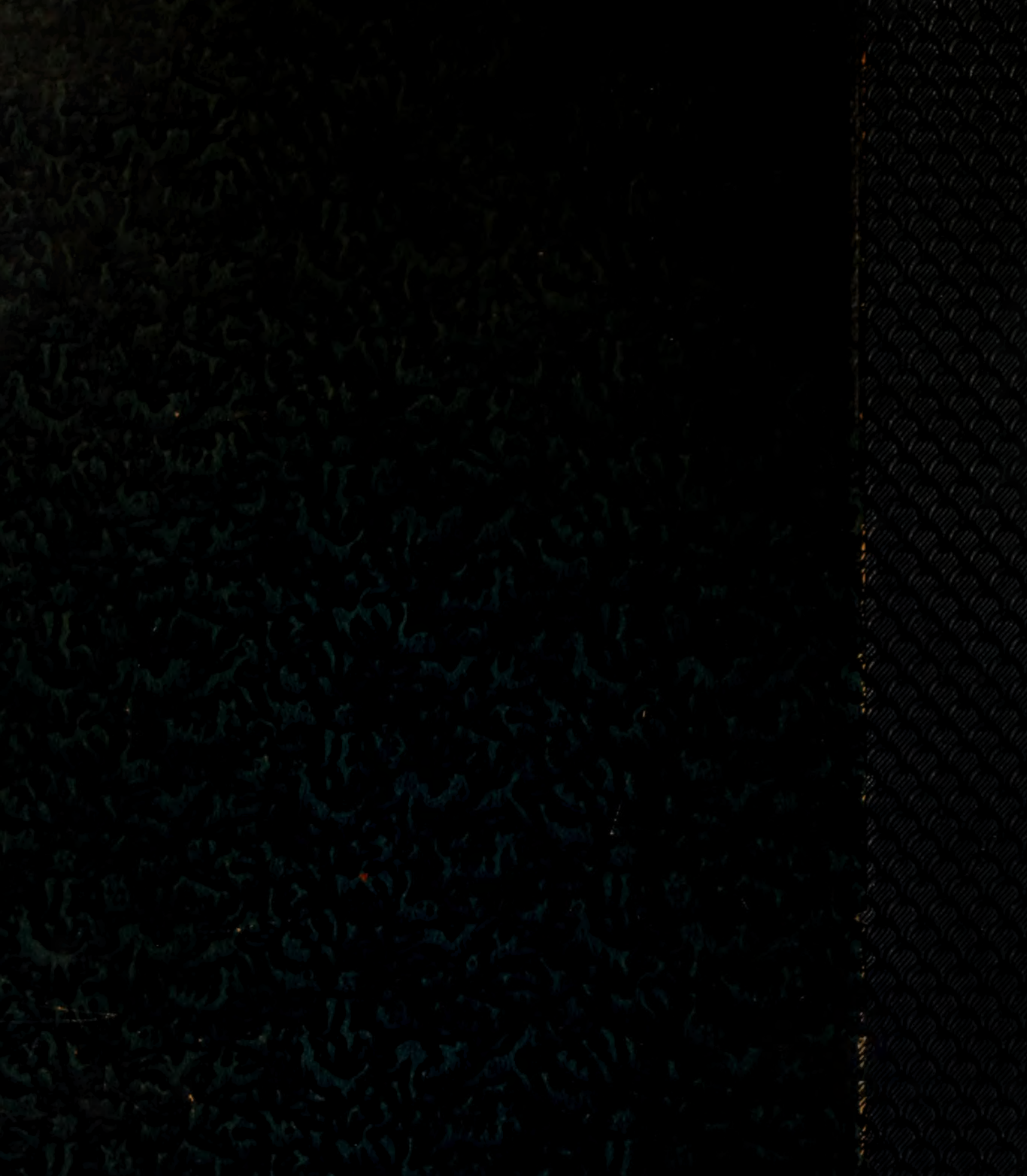